UNIVERSIDADE DE SÃO PAULO

FACULDADE DE FILOSOFIA, LETRAS E CIÊNCIAS

HUMANAS

DEPARTAMENTO DE HISTÓRIA

PROGRAMA DE PÓS-GRADUAÇÃO EM HISTÓRIA SOCIAL

Filipe Nicoletti Ribeiro

Império das incertezas: política e partidos nas décadas finais da monarquia brasileira (1868-1889)

São Paulo 
UNIVERSIDADE DE SÃO PAULO

FACULDADE DE FILOSOFIA, LETRAS E CIÊNCIAS

HUMANAS

DEPARTAMENTO DE HISTÓRIA

PROGRAMA DE PÓS-GRADUAÇÃO EM HISTÓRIA SOCIAL

Filipe Nicoletti Ribeiro

\section{Império das incertezas: política e partidos nas décadas finais da monarquia brasileira (1868-1889)}

Dissertação apresentada ao Programa de Pós-Graduação em História Social da Faculdade de Filosofia, Letras e Ciências Humanas da Universidade de São Paulo para obtenção do título de Mestre.

Orientadora: $\operatorname{Prof}^{\mathrm{a}} \operatorname{Dr}^{\mathrm{a}}$ Monica Duarte Dantas

São Paulo 


\section{Resumo}

A presente dissertação tem como objeto de estudo os dois grandes partidos monárquicos, Conservador e Liberal, nas décadas finais do Império. Partindo de temas fundamentais às disputas políticas do período, como eleições, autonomia provincial e escravidão, pretende-se compreender de que forma as importantes inflexões ocorridas na década de 1880 impactaram o sistema político-partidário do Império. Essas inflexões, já apontadas pela historiografia, dizem respeito ao recrudescimento das tensões políticas, ocorrido em consonância com o robustecimento da mobilização de forças extraparlamentares, que ganharam radicalidade no período. O surgimento de um movimento social organizado contrário à escravidão e as reivindicações de crescentes setores da população por maior participação nos negócios públicos acabaram por cindir profundamente a elite política do país. Se a solução para alguns foi a resistência obstinada, outros se mostraram dispostos a tomar parte na formulação de um projeto denominado por eles mesmos de monarquia democrática, que teve em seu horizonte a abolição incondicional da escravidão, a vigorosa expansão do direito ao voto, a reforma do Estado, o alargamento da autonomia provincial e a disseminação do acesso à terra.

Palavras-chave: Império do Brasil, partidos políticos, República, eleições, escravidão, federalismo

E-mail do autor: fnicoletti2@gmail.com 


\begin{abstract}
The present thesis aims to study the two major political parties in the Brazilian monarchy, the so-called Conservative and Liberal parties, during the regime's final decades. Taking into account fundamental themes to the period's political strife, such as the electoral system, provincial autonomy and slavery, how major changes, throughout the 1880s affected the Empire's political party system. Those changes, recurrently discussed by historians, were driven by an aggravation of political tensions, together with the strenghtening of forces outside the traditional representative institutions, radicalized in those years. The emergence of an organized movement aiming to abolish slavery and the growing claims of the population for greater intervention in public affairs profoundly divided the country's political elite. If to some resistance was the only solution, others showed disposition in taking part in the advancement of a project of a Democratic monarchy, a term some of them used profusely. That project had, among its priorities, the unconditional abolition of slavery, the vigorous expansion of voting rights, the State reform, the concession of larger provincial autonomy and measures toward land reform.
\end{abstract}

Keywords: Brazilian Empire, political parties, Republic, elections, slavery, federation 


\section{Agradecimentos}

Diversas pessoas e instituições tornaram possível a escrita desta dissertação.

Agradeço, primeiramente, à FAPESP, cujo financiamento viabilizou a pesquisa como um todo, inclusive as essenciais viagens ao Rio de Janeiro e Petrópolis.

Nos arquivos dessas cidades, contei com o auxílio de diversas pessoas. Sou grato aos funcionários do Instituto Histórico e Geográfico Brasileiro, do Arquivo Histórico do Museu Imperial, da Biblioteca Nacional e do Arquivo Nacional, pela simpatia e atenção com que sempre me receberam.

Agradeço às professoras Angela Alonso e Miriam Dolhnikoff, que compuseram minha banca de qualificação. Suas críticas construtivas e sugestões valiosas enriqueceram muito as perspectivas de minha pesquisa.

Faço um agradecimento especial a minha orientadora, Monica Duarte Dantas, pela solicitude e paciência constantes. Sua competência e paixão pelo ofício são fontes permanentes de inspiração, que muito me ensinaram sobre o que significa ser historiador.

Sou grato também aos meus queridos amigos, Juliana, André, Carol, Carina, Cristiane, Leonardo, Marina, Cristina, Magrão, Renata e Fillipe. É um privilégio tê-los como companhia tanto em minha jornada acadêmica quanto pessoal.

Acima de tudo, sou eternamente grato a meus pais, Silviane e Joel, meus avós, Anna, Ary, Margarida e Otávio (in memoriam), e minha irmã, Juliana. Sem seu amor incondicional e incentivo constante nada disto seria possível. A eles dedico esta dissertação. 


\section{Sumário}

Introdução

Capítulo 1: Partidos, representação e participação política (1868-1884)

1.1. A historiografia e a crise: a inversão partidária de 1868 e os sentidos da política imperial

1.2. Partidos e eleições: as disputas em torno do sistema eleitoral e a opção pela eleição direta

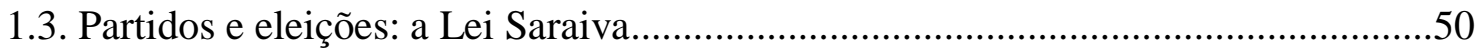

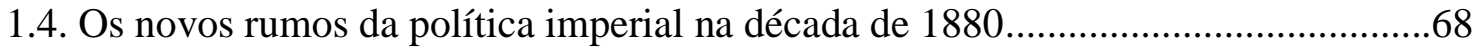

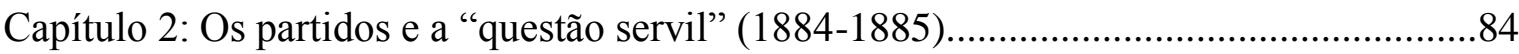

2.1. O projeto de 15 de julho e a dissolução da Câmara dos Deputados.........................89

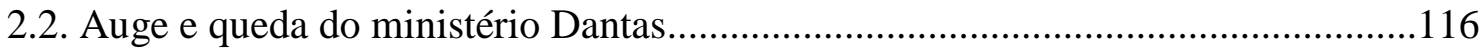

2.3. De Saraiva a Cotegipe: um compromisso efêmero..............................................145

Capítulo 3: Reforma, revolução e resistência: os partidos monárquicos nos últimos anos do

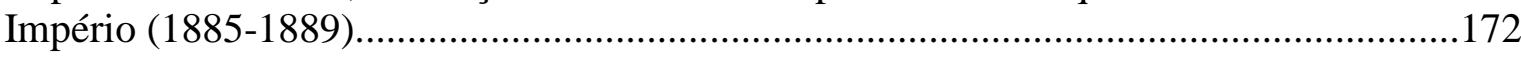

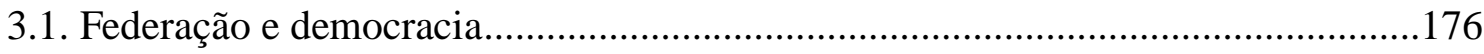

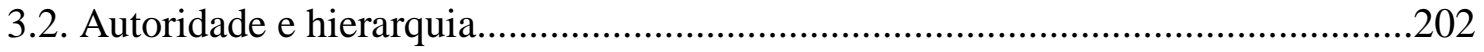

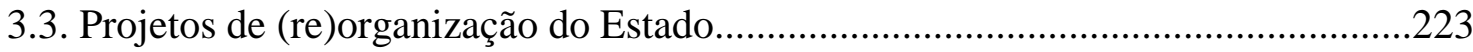

Fontes.

Bibliografia 


\section{Introdução}

A compreensão dos motivos que levaram à derrocada do Estado imperial tem sido uma busca constante desde meus anos de graduação. Já durante minha iniciação científica, realizei uma pesquisa inicialmente comprometida com o estudo da questão fundiária nos anos finais do regime monárquico. A opção por tal tema se deu graças a longas conversas com minha orientadora, bem como pela leitura da bibliografia, em que sua importância é frequentemente destacada. Contudo, apesar de diversos autores indicarem a relevância do assunto para a compreensão do processo que levou à incompatibilização de setores importantes da sociedade imperial com relação ao regime, nenhum deles trata de forma aprofundada do tema. ${ }^{1}$ Intrigou-me, portanto, um aparente paradoxo: como era possível que um tema tão fundamental para conflitos políticos que dilaceraram o país ao longo do tempo não recebesse um tratamento mais extenso da historiografia no que se refere à sua relevância para a queda da monarquia, tendo em vista que naquele momento grassavam projetos mais ou menos radicais de reforma agrária ou "democracia rural"? ${ }^{2}$

Tal interrogação começou a ganhar outros contornos quando, efetivamente, tomei contato com a documentação do período, a começar pelos Anais do Parlamento. A partir de sua leitura, foi possível iniciar a compreensão da imensa complexidade do contexto político do país nos anos finais do regime monárquico. Também comecei a compreender a dimensão do problema em que havia mergulhado. A questão da terra aparecia, das mais diferentes formas, nos discursos de políticos de diferentes origens e cores partidárias. Todos, do conservador mais "emperrado" ao liberal mais radical, defendiam o desenvolvimento da pequena propriedade territorial como um desiderato necessário, e desejável, para o país. Desta forma, o primeiro desafio com que me deparei foi entender o que significava "pequena propriedade territorial" para cada um daqueles políticos.

1 Diversos autores sugerem, geralmente de passagem, a potencial importância de perspectivas de uma reforma agrária para o crescimento da rejeição, entre setores da elite, do regime monárquico. Ver, por exemplo: Peter L. Eisenberg, Modernização sem mudança: a indústria açucareira em Pernambuco, 1840-1910, Rio de Janeiro: Paz e Terra/ Campinas: Unicamp, 1977; Joselice Jucá, André Rebouças: reforma \& utopia no contexto do segundo império, Rio de Janeiro: Odebrecht, 2001; Lígia Osório Silva, Terras devolutas e latifúndio: efeitos da lei de 1850 (2a ed.), Campinas: Editora da Unicamp, 2008.

2 A exceção é Richard Graham, "Landowners and the overthrow of the Empire", Luso-Brazilian Review, v. 7, no 2, dez/1970, pp. 44-56. Neste pequeno artigo, o historiador indica considerar de fundamental importância para a derrubada do Império o temor que os grandes proprietários nutriam com relação a perspectivas de reforma agrária. 
Para isso, foi necessário uma intensa imersão na documentação e na bibliografia sobre o período, tendo em vista os mais variados temas. O abolicionismo era, necessariamente, um deles. Passei a estudar o movimento e suas bandeiras, por meio da leitura de livros, panfletos, artigos e da imprensa da época, além de acompanhar a atuação de parlamentares ligados à causa. Pude perceber o imenso emaranhado de projetos e expectativas que marcavam um movimento extremamente plural. Por diversas vezes, me encontrei perplexo diante de atos e discursos aparentemente contraditórios, vindos da pena do mesmo autor ou das ações do mesmo militante. Percebi que as trajetórias políticas e pessoais aparentemente acidentadas daqueles homens eram, acima de tudo, representativas de constantes e sensíveis mudanças em suas perspectivas e possibilidades objetivas, informadas por um contexto histórico particularmente crítico e permanentemente cambiante.

Tive, frequentemente, que voltar da documentação à bibliografia, flutuando constantemente entre a desesperadoramente crescente quantidade de dados dispersos em minhas anotações. Relendo-as a cada avanço, percebia relações que antes não havia sido capaz de estabelecer e desfazia outras que perdiam seu sentido. A questão da terra dava espaço ao problema da escravidão, que por sua vez cedia lugar ao tema da federação, que logo minguava diante das polêmicas em torno da expansão do sufrágio.

Trilhando este caminho tortuoso pude perceber, finalmente, o óbvio oculto: estava diante de mim um contexto de profunda crise social e político-institucional, talvez sem precedentes na história do país desde sua fundação. Resultou disto passar a realizar uma leitura mais crítica das abordagens historiográficas sobre o fim do Império.

Por vezes naturalizando o declínio do regime monárquico, encarando sua queda como destino manifesto de uma inexorável obsolescência, a historiografia tem, constantemente, retratado a monarquia brasileira como inevitavelmente refratária à modernidade. Centralizado, autoritário, iliberal, com lastro social em apenas alguns setores minoritários visceralmente ligados ao trabalho escravo, o Império do Brasil é geralmente retratado como resultante de uma ruptura mais ou menos superficial com seu passado colonial, uma inflexão dentro da ordem e do status quo, destinada justamente a manter essa mesma ordem e o status quo ante. As forças da modernidade, surgidas na fase final de sua trajetória, um "plano inclinado", parecem suficientemente autoconscientes de que sua derrocada era apenas uma questão de tempo. Atacando o escravismo, a centralização sufocante, a supremacia da Coroa no arranjo político teriam minado pouco a pouco as bases de sustentação do regime, cujas sete décadas de existência teriam se alicerçado em 
"ficções" e "simulacros" autolegitimadores.

Partindo de tais percepções, pude compreender o porquê de minha perplexidade ao me deparar com as renhidas disputas políticas que marcaram seu fim. Aquele contexto crítico, assoberbado por dissensos, projetos conflitantes e expectativas distintas para o país, parecia perder muito de sua complexidade ao não se reconhecer o fato de que os sujeitos históricos de então, em sua imensa maioria, não tinham no horizonte a superação ou subversão do regime. Pelo contrário, se digladiavam pelo destino do Império do Brasil, formulavam projetos para conduzi-lo por este ou por aquele caminho, não ao precipício. Pareceu-me preciso compreender tais projetos e expectativas, então, tendo em vista as prioridades e possibilidades dos indivíduos que os preconizavam. Desde então, a recomendação de um dos maiores historiadores que o século XX conheceu jamais deixou de informar minha pesquisa:

[...] olhemos a história como história - homens situados em contextos reais (que eles não escolheram) e confrontados perante forças incontornáveis com uma urgência esmagadora de relações e deveres, dispondo, apenas, de uma oportunidade restrita para inserir sua própria ação - e não como um texto para fanfarronices do tipo assim deveria ter sido. ${ }^{3}$

Confesso que terminei minha iniciação científica com muito menos respostas do que interrogações. A perplexidade, contudo, é uma das maiores armas do historiador.

Iniciei o mestrado intentando um grande aprofundamento no contexto político do país em seus anos finais, a partir do estudo dos projetos, expectativas e posicionamentos de algumas das figuras mais realçadas pela bibliografia e documentação até então consultadas. Percebendo o ministério Dantas (1884-1885), pelas imensas mobilizações e disputas políticas que encetou, como um marco crítico daquele período, e partindo de seu estudo, como um momento de grave cisão intra-elite, procurei compreender as crescentes diferenças entre os projetos e expectativas dos dois grandes partidos monárquicos a partir de meados da década e de que forma influenciaram na crise derradeira do regime e informaram as movimentações políticas posteriores ao golpe de Estado de 15 de novembro.

Contudo, ao partir de Dantas, a questão servil acabou tomando uma proeminência desmesurada em minha pesquisa, baralhando consideravelmente os planos iniciais, que tinham num diagnóstico da política geral seu objetivo. As dificuldades ficaram claras

3 E. P. Thompson, As peculiaridades dos ingleses e outros estudos. Campinas: Editora da Unicamp, 2001, p. 140. 
durante meu exame de qualificação, no qual as professoras Miriam Dolhnikoff e Angela Alonso apontaram para inconsistências consideráveis no encaminhamento da dissertação. Suas sugestões e conversas posteriores com minha orientadora lançaram novas luzes sobre minhas prioridades. A partir de então, pude reordenar minha pesquisa.

Diante das indicações da historiografia, que geralmente estabelece na inversão partidária de 1868 um marco crítico para o realinhamento dos partidos políticos no Império, após as experiências da Conciliação e da Liga Progressista, retomei a leitura da bibliografia, centrando-me no tema. A partir daí, passei a ter uma compreensão renovada dos problemas enfrentados durante o período histórico que optei por estudar. Ao tema da escravidão se assomaram outras questões, ligadas ao sistema eleitoral, à autonomia provincial e às sensíveis transformações políticas extraparlamentares que marcaram o país no decorrer, especialmente, da década de 1880. Nesse sentido, percebi que não poderia privilegiar um ou outro tema, por mais gigantesco que se apresentasse o desafio de tentar compreendê-los em sua complexidade plural. Foi exatamente a consciência desta pluralidade que me possibilitou enxergar, com alguma precisão, espero, coerência nas ações dos sujeitos históricos que tanto me intrigavam. A partir de então, foi possível entender que temas aparentemente díspares ou apenas indiretamente conectados eram, na verdade, partes do mesmo todo. As perspectivas quanto à terra, à escravidão, à autonomia provincial, à participação política, entre outras temáticas, integravam projetos distintos para o país, que foram sendo formulados e readaptados de acordo com contextos históricos específicos, demandas objetivas por eles informadas e necessidades materiais prementes. Ao abandonar a tentativa de encontrar coerência na singularidade ou nos pequenos eventos, abriram-se possibilidades para encontrá-la na complexidade plural das efetivas relações sociais e perspectivas políticas esposadas por sujeitos históricos inseridos num tempo em que imperava a incerteza. É, ao menos, o que espero do presente estudo: que ele possa, dentro das inescapáveis limitações de seu autor, e dos limites de uma dissertação de mestrado, contribuir para indicar novos caminhos no sentido da compreensão de um momento fundamental da história do país.

Tendo tudo isto em vista, esta dissertação se divide em três capítulos. No primeiro, realizo uma discussão historiográfica sobre os partidos monárquicos e os sentidos da crise de 1868, quando voltaram ao poder os conservadores e se rearticularam, na oposição, os liberais. Devido à grande importância que ganhou a questão eleitoral nesse processo, apontada por interpretações clássicas e mais recentes, o capítulo segue com a discussão da 
legislação eleitoral do Império e a opção pela eleição direta. No segundo e terceiro subcapítulos trato justamente desse tema, apresentando um histórico da questão e abordando-se as disputas em torno da reforma do sistema eleitoral encetadas pela ascensão dos liberais após uma década na oposição. Busco demonstrar que a Lei Saraiva foi fruto de renhidas disputas e exaustivas negociações entre os dois grandes partidos monárquicos, mas que, ao fim, teve um tom marcadamente liberal, que parece ter engendrado alterações consideráveis na economia interna de ambos os partidos constitucionais. Na quarta seção do capítulo deixo temporariamente o Parlamento, onde era discutida a reforma, e volto os holofotes para a nova situação política do Império a partir do início da década de 1880, marcada pelo recrudescimento da conflagração social e robustecimento das forças políticas extraparlamentares, cujas reivindicações passaram a ter uma influência sem precedentes nos destinos políticos do país, congregando, de forma definitiva, a bandeira da abolição da escravidão à luta pela democratização política do Império.

O segundo capítulo trata da culminância institucional desse conflagrado contexto, com a ascensão de um ministério liberal-abolicionista, liderado pelo senador baiano Manuel Pinto de Souza Dantas e amplamente sustentado por forças radicalizadas de dentro e de fora das instituições representativas do país. Procuro demonstrar, nos dois primeiros subcapítulos, as intensas transformações geradas pelas lutas políticas de meados da década, quando a questão servil se tornou, de uma vez por todas, um catalisador de tensões sociais e políticas latentes na sociedade imperial, servindo de repositório a uma agenda democrática ${ }^{4}$ crescentemente radicalizada que ultrapassava em muito a libertação dos escravos. No terceiro subcapítulo, busco abordar de que forma forças moderadas e conservadoras tentaram uma rearticulação no sentido da neutralização dessas movimentações "anárquicas", o que, ao fim, com a derrota da "solução liberal" para o problema servil e a subsequente ascensão conservadora, acabou por iniciar a rearticulação do Partido Liberal na oposição.

Os percalços desta rearticulação serão abordados no último capítulo da dissertação. Nele tento expor o realinhamento dos liberais na oposição, diante do protagonismo crescente de sua ala radical, que finalmente compeliu o partido, não obstante as hesitações de seus setores mais recalcitrantes, a se comprometer com uma agenda decididamente antiescravista e democrática, que teve na libertação incondicional dos escravos, na reforma

4 As referências constantes à democratização do regime eram feitas pelos próprios contemporâneos e parecem ter se intensificado sobremaneira no decorrer da década de 1880. 
do Estado, na ampliação do sufrágio, na autonomia das províncias e, mesmo, na disseminação do acesso à terra seus horizontes. Simultaneamente, as expectativas em torno da condução do processo de emancipação dos escravos, com a reorganização do Estado a partir de uma lógica de transição gradual, acabou por seccionar irreversivelmente o Partido Conservador, que, como se verá na segunda seção do capítulo, não se mostrou capaz de formular um projeto harmônico e coerente para o país após o colapso do escravismo se provar irresistível. Estas inflexões críticas no ambiente político-partidário do Império parecem ter contribuído decisivamente para a fragilização de suas instituições, que finalmente ruíram após o golpe de Estado de 15 de novembro de 1889. Disto trato na seção final do terceiro capítulo. 


\section{1}

Partidos, representação e participação política (1868-1884)

A década de 1860 foi um período marcado por intensas transformações na política interna e nas relações exteriores do Império do Brasil. Envolvido em uma guerra internacional de grandes proporções, que se prolongou por mais da metade do decênio, o país escravista, carente de forças armadas modernas e regulares, teve de investir pesadamente para transformar sua superioridade demográfica e econômica em inquestionável superioridade militar frente ao vizinho beligerante, o Paraguai de Solano López, no conflito que ficou conhecido como Guerra da Tríplice Aliança. Endividamento e dificuldades financeiras cresciam na proporção em que se tornavam mais complexas as campanhas e em que o país assumia a ofensiva. ${ }^{5}$

A instabilidade política, por sua vez, também foi significativa. Se o Império havia superado os graves desafios da primeira metade do século, em que o Estado e suas instituições sofriam para consolidar-se frente a inúmeras rebeliões, a política parlamentar passou por amplas e severas reconfigurações. Poucos períodos testemunharam tantos embates entre projetos e interesses de forças políticas distintas, em constante realinhamento. Estas forças reconheciam plenamente a legitimidade do Estado imperial e de seu aparato político-institucional, e disputavam sua essência e sua liderança. As transformações pelas quais passou o país nesse período mostram o alcance de tais disputas, até que a própria conformação do Estado passasse a ser questionada por uma pequena, mas sonora, minoria. ${ }^{6}$

Sobre a atividade política, pode-se dizer que foi uma década efervescente. Livros, panfletos, manifestos, circulares e discursos demonstravam a profundidade e a intensidade do debate público, abordando temas que iam do espírito da Constituição e o alcance do papel da Coroa, à forma mais adequada de organização dos pleitos eleitorais; de considerações sobre a separação de poderes e o funcionamento adequado do judiciário, a discussões sobre o caráter centralizado do Estado e a legitimidade desta ou daquela

5 Para a Guerra do Paraguai e seu impacto na política do Império, ver: Sérgio Buarque de Holanda, "Crise do Regime", in: Do Império à República (2 $2^{\mathrm{a}}$ ed.), São Paulo: Difel, 1977 (Col. História Geral da Civilização Brasileira, t. II, v. 5), pp. 7-56; Wilma Peres Costa, A Espada de Dâmocles: o exército, a Guerra do Paraguai e a crise do Império, São Paulo: Hucitec/ Campinas: Editora da Unicamp, 1996.

6 Para os programas dos partidos na década de 1860 e os manifestos republicanos do decênio seguinte, ver: Américo Brasiliense de Almeida e Melo, Os programas dos partidos e o Segundo Império, Brasília: Senado Federal; Rio de Janeiro: Fundação Casa de Rui Barbosa, 1979. 
legislação. Enfim, consolidado o Estado liberal, disputava-se o teor de tal liberalismo, confrontando-se projetos políticos e perspectivas distintas. ${ }^{7}$

Os constantes realinhamentos partidários foram ilustrativos de tal efervescência e da natureza polarizada dos embates. A década se iniciou com a formação de uma aliança política entre setores moderados do Partido Conservador, então no poder, e próceres do "velho liberalismo", que voltavam ao Parlamento após anos de ostracismo, ${ }^{8}$ e terminou com o fim de tal aliança e a reorganização e refundação dos partidos políticos, bem como com o surgimento de uma agremiação oficialmente adepta da superação das instituições monárquicas e outra desejosa de conservá-las, mas somente com a condição de que se modernizassem e passassem a incluir uma agenda mais avançada e inclusiva, social e politicamente. A Liga, depois partido, Progressista, unindo elementos moderados de ambos os grupos em que se polarizava a política do Império, daria origem, após ser apeada do poder, tanto ao novo Partido Liberal quanto ao Partido Republicano, criado, em 1870, sob a inspiração do radicalismo de fins da década anterior. Pairando sobre tudo isso, a guerra. Não é à toa, portanto, que, seguindo a historiografia, a presente narrativa se inicia no episódio em que conflito externo e disputas políticas internas conectaram-se de forma decisiva.

\section{1 - A historiografia e a crise: a inversão partidária de 1868 e os sentidos da política imperial}

Parte importante da historiografia convencionou considerar o ano de 1868 um momento de ruptura na história da monarquia brasileira. ${ }^{9}$ No primeiro semestre daquele

7 Ver, por exemplo: José Murilo de Carvalho, “As conferências radicais do Rio de Janeiro: novo espaço de debate", in: Id. (org.), Nação e cidadania no Império: novos horizontes, Rio de Janeiro: Civilização Brasileira, 2007, pp. 17-41; Silvana Mota Barbosa, A Sphinge Monárquica: o poder moderador e a política imperial, Tese de Doutorado, Campinas: IFCH-Unicamp, 2001, cap. 5 "Os Olhos do Corpo e os Olhos do Espírito: os debates na década de 1860".

8 Para a Liga Progressista, ver: Silvana Mota Barbosa, "A política progressista: Parlamento, sistema representativo e partidos nos anos 1860", in: José Murilo de Carvalho e Lúcia Maria Bastos Pereira das Neves, Repensando o Brasil do Oitocentos: cidadania, política e liberdade, Rio de Janeiro: Civilização Brasileira, 2009, pp. 295-324.

9 Cf. Sérgio Buarque de Holanda, Do Império à República; Wilma Peres Costa, op. cit.; José Murilo de Carvalho, A construção da ordem e Teatro de sombras (4 ${ }^{\mathrm{a}}$ ed.), Rio de Janeiro: Civilização Brasileira, 2003; Id., Liberalismo, radicalismo e republicanismo nos anos sessenta do século dezenove, Working Paper, Centre for Brazilian Studies, Oxford, 2007; Jeffrey D. Needell, The party of order: the conservatives, the state and slavery in the Brazilian monarchy, 1831-1871, California: Stanford University Press, 2006; Id., "Formação dos partidos políticos no Brasil da Regência à Conciliação, 18311857”, São Paulo, Almanack Braziliense (n 10), pp. 5-22, nov. 2009. 
ano, a velocidade dos avanços das tropas da Tríplice Aliança sobre posições-chave do território paraguaio passou por uma considerável desaceleração. A cautela do duque de Caxias, refletida no cuidadoso planejamento dos passos seguintes da exaustiva campanha militar, testava a paciência do governo e da opinião pública. Não demorou muito para que as críticas ao comandante dos exércitos aliados se tornassem mais assíduas e mais severas na imprensa da Corte, especialmente aquela simpática à frágil coalizão ligueira entre progressistas e liberais, que se encontrava no poder. ${ }^{10}$

Já havia, de fato, alguns anos que se aprofundava a deterioração da "aliança ligueira", cindida entre os "progressistas", majoritariamente conservadores dissidentes, e os liberais "históricos". ${ }^{11}$ As crescentes divisões na base de apoio parlamentar haviam sido decisivas, pelo menos desde o segundo ministério chefiado por Zacarias de Góis, de 15 de janeiro de 1864, para o insucesso dos seguidos gabinetes que ocuparam o Poder Executivo no período. Tais fissuras se manifestavam também nas próprias composições ministeriais, que se mostravam invariavelmente instáveis. ${ }^{12}$ Quando Zacarias retornou à presidência do Conselho pela terceira vez, em agosto de 1866, as condições para o exercício do poder político mantinham-se precárias e sua relação com a Câmara dos Deputados era bastante intrincada. ${ }^{13}$ As dificuldades enfrentadas pelo estadista baiano só se aprofundaram com o desenrolar do conflito platino.

A crescente virulência dos ataques a Caxias por parte de folhas situacionistas e os próprios desacordos na condução do conflito tornavam particularmente problemáticas as já conturbadas relações entre o ministério progressista e o general conservador. ${ }^{14}$ Não bastou que o presidente do Conselho assegurasse ao comandante não ter seu governo participação alguma na ofensiva da imprensa; o velho militar se declarou irreversivelmente incompatibilizado com o gabinete e pediu exoneração de seu posto. Após o fracasso de inciativas reconciliadoras, ficou claro que se apresentavam duas possibilidades: a aceitação do ultimato do general ao líder do governo e a retirada do gabinete, o que consistiria em evidente quebra de hierarquia, ou a sustentação de Zacarias e seus colegas, colocando em risco o prosseguimento do conflito no Prata. Deste modo, a solicitação de Caxias causou

10 De acordo com Sérgio Buarque de Holanda, Do Império à República, p 23, os ligueiros formavam "uma organização mal articulada".

11 Cf. Sérgio Eduardo Ferraz, O Império revisitado. Instabilidade ministerial, Câmara dos Deputados e Poder Moderador (1840-1889). Tese de Doutorado em Ciência Política, São Paulo: FFLCH/USP, 2012, pp. 136-150.

12 Ibid., pp. 136-146.

13 Ibid., pp. 146-150.

14 Cf. Roderick J. Barman, Imperador cidadão. São Paulo: Editora Unesp, 2012, pp. 318-319. 
uma espécie de controvérsia que provavelmente não teria espaço em outros tempos. $\mathrm{O}$ ineditismo de tal controvérsia estava em sua própria natureza, caracterizando-se como uma escolha entre a manutenção de uma lógica de Estado que historicamente priorizara os poderes civis sobre os interesses militares e, com a confirmação de Caxias no cargo, a subversão dessa lógica, avalizando o que para muitos políticos do período representava um perigosa ameaça às instituições. ${ }^{15}$

Não obstante os argumentos contrários da maior parte dos conselheiros de Estado, o Imperador deixou claro que estava disposto a transigir com o "ultimato" do general. Com o passar das semanas, as relações entre Coroa e ministério se tornaram crescentemente delicadas. Ciente da fragilidade de sua base de sustentação parlamentar, cortada por profundas divisões, e percebendo que a Coroa privilegiava a resolução do conflito no Prata, favorecendo uma mudança política que garantisse a permanência do comandante das forças aliadas no cargo, Zacarias se utilizou de um fato aparentemente trivial, a discordância em torno da nomeação de um senador pela província do Rio Grande do Norte, para deixar a presidência do Conselho, atribuindo sua queda à falta de confiança manifestada pela Coroa. ${ }^{16}$ Após a recusa do senador baiano em oferecer um nome para a sucessão ministerial, d. Pedro apelou a um dos principais chefes do partido de Caxias, o "cardeal" conservador Itaboraí, ${ }^{17}$ que formou novo gabinete.

15 Cf. Sérgio Buarque de Holanda, Do Império à República, pp. 90-104.

16 Cf. Sérgio Ferraz, op. cit., pp. 146-150.

17 Joaquim José Rodrigues Torres, visconde de Itaboraí, fazia parte do grupo que irreverentemente fora chamado "consistório", composto pela facção mais dura do Partido Conservador. Eusébio de Queirós seria o "papa" da ala "vermelha", enquanto, Paulino José Soares de Souza, visconde do Uruguai e o visconde de Itaboraí seriam seus "cardeais do consistório". Apesar de serem disseminadamente tratados pela historiografia como líderes da facção chamada "saquarema" do Partido Conservador, nome este que teria origem no município homônimo, onde foram, nos anos 1830, realizados diversos encontros políticos que ajudaram a definir o futuro do então embrionário "Partido da Ordem", a presente dissertação se absterá de tratá-los por tal alcunha, seguindo as indicações de Sérgio Buarque de Holanda, ao alertar para o fato de que o termo "saquarema" para descrever os "conservadores da velha guarda" já caía em desuso no início na década de 1860. Cf. Sérgio Buarque de Holanda, Capítulos de história do Império (org. de Fernando Novais), São Paulo: Companhia das Letras, 2010, pp. 95-96. Pesquisas mais recentes têm mesmo questionado o papel preeminente frequentemente atribuído a tal grupo na consolidação e nos destinos da monarquia brasileira. Paula Ribeiro Ferraz, por exemplo, demonstra que, mesmo durante o período de maior prestígio político da chamada "trindade" em meados do século XIX, geralmente tratado pela historiografia como o momento de consolidação do Estado imperial e vitória do projeto político conservador esposado por Eusébio, Uruguai e Itaboraí, figuras-chave nos ministérios presididos por Pedro Araújo Lima (1848-1849) e José da Costa Carvalho (1849-1852), havia grande e feroz oposição parlamentar aos gabinetes, por parte de deputados eles mesmos conservadores, o que sugere não ser exata a ideia de uma precedência "saquarema" em relação ao restante do Partido Conservador que mantê-lo-ia sob estrita disciplina. Cf. Paula Ribeiro Ferraz, O Gabinete da Conciliação: atores, ideias e discursos (1848-1857), Dissertação de Mestrado em História, Juiz de Fora: UFJF, 2013. Deste modo, esclarece-se melhor a opção pela utilização, nesta dissertação, de outras alcunhas para tratar de tal ala conservadora, como, por exemplo, "vermelhos". 
Como já observado, a queda do terceiro ministério Zacarias, e com ele da Liga Progressista, e a subsequente "inversão" partidária, com a ascensão do Partido Conservador, na figura do visconde de Itaboraí, teria precipitado, para alguns autores, a crise política mais aguda pela qual passou o país durante o longo Segundo Reinado, decisiva para o desenrolar das duas décadas seguintes e seu conhecido desfecho, a 15 de novembro de $1889 .{ }^{18}$ Outros autores, mesmo não atribuindo ao episódio citado a mesma gravidade, também consideram a queda do terceiro ministério Zacarias um marco crítico da história do Império, influenciando decisivamente os eventos que, a partir da década de 1870 , colocariam o regime em rota descendente. ${ }^{19}$

Segundo a interpretação de Sérgio Buarque de Holanda, o dilema entre poder civil e lógica militar pôde ocorrer naquele momento, pois, além de consumir as finanças do Império, o exaustivo esforço de guerra comprometia diretamente seu prestígio, tornando particularmente intolerável qualquer ameaça a um triunfo decisivo sobre o Paraguai de Solano López. Ademais, especialmente obstinado neste sentido se encontrava o chefe do Estado, conferindo ao sucesso militar do país a preeminência sobre quaisquer outras considerações. Destarte, as ações do monarca, fundamentais no desenrolar da crise, e o próprio conteúdo do dilema causado pelo desentendimento entre Caxias e Zacarias teriam profundas, e derrisórias, consequências para o regime. ${ }^{20}$ Nesse sentido, o papel do Imperador na queda da Liga e na reabilitação dos conservadores seria a chave para se compreender não apenas as origens da crise do regime monárquico, mas sua própria natureza. $^{21}$ Vejamos.

De acordo com o autor, a Constituição do Império garantia um lugar central ao monarca na organização política do país. Investindo a Coroa do Poder Moderador, que pairava "acima de todos os outros poderes", a Carta outorgada permitiria uma constante intervenção do chefe de Estado na correlação de forças políticas, afiançando prerrogativas a ele exclusivas, como a possibilidade de dissolver a Câmara dos Deputados e nomear senadores em lista tríplice após eleições. Por outro lado, o monarca também exercia o Poder Executivo, tendo influência direta nas organizações ministeriais e, por meio de seus ministros, na condução da administração pública. Essas amplas prerrogativas reais,

18 Cf. Sérgio Buarque de Holanda, Do Império à República (2ª ed.); Wilma Peres Costa, op. cit.

19 Cf. José Murilo de Carvalho, A construção da ordem e Teatro de sombras; Id., Liberalismo, radicalismo $e$ republicanismo; Jeffrey D. Needell, The party of order; Id.,"Formação dos partidos políticos no Brasil da Regência à Conciliação, 1831-1857".

20 Cf. Sérgio Buarque de Holanda, Do Império à República, pp. 90-104.

21 Ibid., pp. 105-106. 
inscritas na lei fundamental do Império, teriam sua limitação no que Sérgio Buarque chama de "constituição não escrita". Discreto e moderado por temperamento, d. Pedro II assegurava aos grupos políticos rivais, que tomavam parte nos negócios públicos por meio dos partidos constitucionais, o revezamento no poder. Este bipartidarismo inspirado pelo alto seria condição sine qua non da existência de um simulacro de sistema representativo, em que topo e base se encontrariam deslocados. ${ }^{22}$

Seguindo este caminho interpretativo, não é difícil perceber a relevância que se atribui ao monarca como o ator mais importante na "ficção" representativa. Sua dedicação ao papel de articulador do jogo político e sua discrição no cumprimento de tais obrigações seriam essenciais ao funcionamento de todo o sistema. O revezamento entre os grupos políticos rivais no poder devia, deste modo, respeitar um certo ritual em que a intervenção da Coroa fosse o menos explícita possível, o que era necessário para a ilusória estabilidade do regime. ${ }^{23}$ No entanto, a situação emergencial engendrada pelo desgastante conflito armado no Prata acabou por ter um grave impacto em tal arranjo político.

Seguindo e apresentando novos elementos à interpretação clássica de Holanda, Wilma Peres Costa destaca que o duplo advento da Liga Progressista e da entrada do país em uma guerra externa de grandes proporções testou de forma inédita os limites do regime. ${ }^{24}$ Funcionando sobre bases clientelares, o sucesso dos dois grandes partidos monárquicos, Conservador e Liberal, em manter a disputa entre facções sob a fachada ordeira da ficção democrática seria, para a autora, condicionado por sua capacidade de ascender periodicamente ao poder do Estado, tendo acesso a cargos e benesses e distribuindo-os por suas amplas clientelas. O surgimento de uma terceira força política, patrocinada pela Coroa, longe de romper com tal lógica, tê-la-ia tensionado consideravelmente. Isto porque, se a Liga interrompeu a rotação dos partidos tradicionais no topo da política nacional, não teria sido capaz de constituir-se ela mesma em partido e ter acesso, por si mesma, a tais redes clientelares. Formados por conservadores dissidentes e liberais moderados, os governos ligueiros tinham relativo sucesso ao se utilizar da máquina eleitoral para vedar a entrada do Partido Conservador na Câmara dos Deputados, mas não podiam fazer o mesmo quando se tratava dos liberais históricos, a quem se encontravam politicamente ligados. Tal grupo de históricos se provou uma resiliente e, em diversos momentos, feroz oposição aos

22 Cf. Sérgio Buarque de Holanda, Do Império à República. Ver especialmente Livro Primeiro "Crise do regime" e Livro Segundo "O pássaro e a sombra".

23 Ibid.

24 Cf. Wilma Peres Costa, op. cit., esp. cap. 6 "Política e Guerra". 
progressistas no ramo temporário do Poder Legislativo, enquanto os conservadores mantinham suas posições no Senado e no Conselho de Estado, de onde podiam desferir incansáveis ataques aos gabinetes. Desta feita, durante toda a fase inicial da guerra, as fragilidades e limitações políticas da Liga estiveram em evidência. ${ }^{25}$ Não é de se estranhar, portanto, que quando se toma o conflito no Prata como ponto de referência, o quadro pintado pela autora pareça ainda mais intrincado.

As forças armadas não teriam passado incólumes aos arranjos da alta política e da própria estrutura da sociedade imperial, cujas características patrimoniais e escravistas comprometeriam grandemente a capacidade do Estado em exercer o monopólio da violência. ${ }^{26}$ Dada a interferência da lógica político-partidária nas altas cúpulas das forças armadas, destaca Costa, as disputas e incompatibilidades se tornaram mais e mais virulentas, o que teria comprometido o desenrolar do conflito platino. ${ }^{27} \mathrm{O}$ ápice destas contradições teria sido a queda de braço entre Caxias e o ministério progressista chefiado por Zacarias de Góis. A queda do gabinete Zacarias e a ascensão dos conservadores teria, deste modo, desnudado o imenso poder de que dispunha o Imperador, comprometendo o funcionamento do mecanismo que promovia a "alternância entre clientelas" e, destarte, colocando em xeque o papel da própria Coroa no "conjunto do sistema". ${ }^{28}$

Outra importante interpretação historiográfica alia, à guerra, a centralidade do monarca no sistema político imperial para a compreensão da grave crise iniciada em fins da década de 1860. Roderick Barman atribui ao Imperador o papel-chave na condução político-institucional do regime. ${ }^{29}$ Para o autor, o alcance do poder que detinha o monarca teria se desvelado quando ele, terminantemente decidido a garantir uma vitória total da Tríplice Aliança sobre o Paraguai de Solano López, realizou o que Barman chama de "barganha faustiana". Ao apear do poder o gabinete progressista e patrocinar a ascensão de Itaboraí, o Imperador teria utilizado sua ampla autoridade para favorecer, explicitamente, uma das "facções políticas concorrentes". Isto significa que o custo da vitória na guerra foi ter sido a "imparcialidade da monarquia" fatalmente comprometida, e sua estabilidade,

25 Ibid., pp. 222-224.

26 Ibid., pp. 226-236.

27 Ibid., pp. 237-243.

28 Ibid., p. 254. A autora não nega a legalidade da ação de D. Pedro, afirmando que o monarca agia dentro de suas prerrogativas constitucionais. Possuindo, porém, o ministério ligueiro maioria no Parlamento, a intervenção da Coroa teria parecido aos contemporâneos um ato próximo a um golpe de Estado, rompendo com a "constituição não escrita" garantidora do bipartidarismo e, portanto, com o "espírito do regime”. Cf. Sérgio Buarque de Holanda, Do Império à República, pp. 21-40.

29 Cf. Roderick J. Barman, op. cit. 
"minada como nunca". 30

Compreende-se, pelo que foi exposto até aqui, que importante linha interpretativa confere um significado mais do que decisivo à inversão partidária de meados de 1868 para todo o funcionamento do sistema político do Império a partir de então. Seguindo tais estudos, se evidencia a percepção de que o Estado imperial, escravista e marcado por uma política de cunho patronal e clientelista, dependente da intervenção ativa do monarca para garantir a alternância de clientelas em um sistema representativo ambíguo, ao envolver-se em uma guerra moderna entre Estados modernos, ${ }^{31}$ deparou-se com diversas contradições que se provaram profundamente derrisórias. A necessidade de vitória na guerra teria levado o monarca a desvelar a dimensão de seu poder, colocando a razão de Estado acima dos interesses político-partidários das facções, ${ }^{32}$ traduzidos nas "derrubadas" e na consequente rotatividade dos partidos no poder, o que mantinha vivos os laços clientelistas, responsáveis pela adesão dos poderes locais e provinciais à Corte, centro irradiador de cargos e benesses. Desta forma, o próprio monarca teria subvertido a ordem imperial. ${ }^{33}$

Nestes termos, a queda da Liga Progressista, em meio à súbita ascensão do Partido Conservador ao poder, tomou contornos severos quando liberais históricos e conservadores dissidentes realizaram diversas tentativas de rearticulação, enquanto ensaiavam um repertório cada vez mais crítico à organização política do Império. Se, para muitos desses políticos, as críticas ao poder pessoal não foram ao extremo de incompatibilizá-los com o regime, caso de homens como José Tomás Nabuco de Araújo, José Antônio Saraiva e o próprio Zacarias de Góis, todos membros do novo Partido Liberal, refundado em 1869, outros seguiriam o caminho que Sérgio Buarque de Holanda considera corolário das críticas às prerrogativas do Poder Moderador, caso de Joaquim Saldanha Marinho e Francisco Rangel Pestana, signatários do Manifesto Republicano de $1870 .^{34}$

30 Ibid., p. 322.

31 Aqui com respeito ao monopólio da violência, dúbio em sociedades escravistas. Cf. Wilma Peres Costa, op. cit., pp. 242-243.

32 "A guerra não deixou qualquer dúvida sobre a supremacia de D. Pedro II dentro do sistema", afirma Roderick. J. Barman, op. cit., pp. 329-330.

33 Cf. Wilma Peres Costa, op. cit., cap. 6 "Política e Guerra".

34 Isto porque, para o autor, a mera reforma não seria capaz de restabelecer equilíbrio ao regime, dependente por essência da intervenção do monarca. Cf. Sérgio Buarque de Holanda, Do Império à República, pp. 116-120 e 256-264. A descrição da reorganização partidária feita pelo autor transparece tal perspectiva (ou ausência de perspectiva, ao menos quando se tem em vista o regime monárquico), particularmente quando se refere aos radicais e futuros republicanos pelo epíteto de "impacientes", o que sugeriria que seu diagnóstico da impossibilidade de reforma das instituições imperiais era correto, sendo reconhecido com mais ou menos vagar ao longo dos anos seguintes. Para Holanda, a substituição do terceiro ministério Zacarias, pela maneira que foi feita, não apenas deixou "claros o artifício e a burla em 
A nova correlação de forças originada da inversão partidária de 1868 ganha cores intensas em outra interpretação fundamental da política do período.

Segundo José Murilo de Carvalho, a derrubada do ministério Zacarias teria sido o ponto final de uma configuração política que datava da primeira metade da década de 1850 . Após a derrota liberal nas rebeliões da década de $1840,{ }^{35}$ havia sido possível ao Partido Conservador ampliar imensamente seu poder, o que teria o potencial de comprometer o funcionamento do sistema imperial como um todo, já que este se sustentaria na "alternância do poder dos setores hegemônicos, mas conflitantes, da elite", o que significava que a exclusão de um deles afetaria "a legitimidade do governo e, eventualmente, a do próprio regime". ${ }^{36}$ Percebendo isto, o marquês de Paraná liderou o movimento de Conciliação dos dois grupos políticos, reabilitando as lideranças do combalido Partido Liberal. Tal iniciativa despertou a ira da ala "vermelha" do Partido Conservador, dividindo-o entre aqueles que apoiavam a política de Paraná e estes últimos, que lhe faziam oposição. Esta divisão se manteve mesmo após a inesperada morte do marquês, influenciando a formação, no início dos anos 1860, da Liga Progressista, uma aliança política entre liberais e conservadores "dissidentes", rompidos com os "saquaremas". 37

Pois bem, afirma o autor, esses quinze anos teriam sido o ensaio de uma política que excluía do poder a ala mais "emperrada" do Partido Conservador, possibilitando a construção de um novo bipartidarismo, em que de um lado estariam os moderados progressistas e de outro os liberais. Em outras palavras, a inversão partidária de 1868, ao apear a instável Liga Progressista do poder, devolvendo-o aos minoritários conservadores "vermelhos", impediu que o reformismo ensaiado ao longo da década de 1860

que todo o sistema assentava", mas alterou todo o horizonte político dos contemporâneos: "Apanhados de supetão pela extraordinária desenvoltura de que o rei se mostrou capaz, ao fazer uso dos desmedidos poderes de que efetivamente dispunha, os históricos e os progressistas renunciaram, ao menos no âmbito parlamentar, às suas divergências, para cerrarem fileira em volta do estadista que os caprichos de São Cristóvão acabavam de sacrificar tão duramente. De fora só haviam ficado os mais impacientes, que passarão a formar o bando dos radicais, já na antessala do Partido Republicano a ser fundado dois anos mais tarde”. Id., Capítulos de história do Império, p. 147.

35 Para uma recente abordagem das revoltas liberais de 1842, ver: Erik Hörner, "Cidadania e insatisfação armada: a 'Revolução Liberal' de 1842 em São Paulo e Minas Gerais”, in Monica Duarte Dantas (org.), Revoltas, motins, revoluções: homens livres pobres e libertos no Brasil do século XIX, São Paulo: Alameda, 2011, pp. 329-354. Para a revolta de 1848 em Pernambuco, ver: Marcus J. M. Carvalho e Bruno Dornelas Câmara, “A Rebelião Praieira”, in Ibid., pp. 355-389; ver também o importante estudo de Izabel Andrade Marson, O império do progresso: a Revolução Praieira em Pernambuco (1842-1855), São Paulo: Brasiliense, 1987.

36 Cf. José Murilo de Carvalho, Liberalismo, radicalismo e republicanismo, p. 2.

37 Ibid., pp. 2-3. 
conquistasse a política brasileira. Caso o Partido Conservador tivesse sido mantido no ostracismo em que ultimamente se encontrava, a política imperial ganharia contornos de uma polarização entre progressistas e liberais históricos, que necessariamente implicaria na disputa pela implementação de uma agenda que previa a própria reforma do sistema representativo e a possível construção de um parlamentarismo mais autêntico. Ascendendo Itaboraí e seus correligionários, aquela deixava de ser uma perspectiva provável, pois com eles regressaria ao poder o velho repertório conservador. ${ }^{38}$ Isto significa, para Carvalho, que, doravante, o próprio Imperador deveria passar a agir explicitamente como propulsor das reformas que considerava necessárias ao Brasil.

De fato, a interpretação de José Murilo de Carvalho tende a dar amplo destaque aos acontecimentos de 1871, ano da promulgação da lei que iniciou o desmonte gradual da escravidão no país. Para o autor, naquele momento, se deu, simultaneamente, o ápice e o início do declínio do regime monárquico. Nesse sentido, apesar de a historiografia até aqui estudada convergir no destaque ao papel de protagonismo da Coroa na promoção das reformas subsequentes aos eventos de 1868 e ao fim da guerra, ele se torna especialmente decisivo na interpretação de Carvalho, fundamentalmente no que diz respeito à política de emancipação promovida pelo monarca, que teria causado um forte abalo nos alicerces do regime, de modo que, sendo a escravidão o "cancro que corroía a sociedade", seria ela "o princípio que minava por dentro as bases do Estado imperial, e que, ao final, acabou por destruí-lo". ${ }^{39}$ Vejamos.

O papel de destaque da Coroa no topo do sistema político do Império seria parte de uma "dinâmica política nacional" formada por coalizões distintas entre "setores da elite e setores de classe", ${ }^{40}$ sendo os partidos políticos expressões de tais divisões. Como fruto da aliança entre a magistratura e a grande agricultura de exportação, com tendências políticas centralizadoras e resistentes a reformas, o Partido Conservador constituía o esteio fundamental para a estabilidade do regime, combinando, nas suas fileiras, a "elite política" nacional", isto é, a alta burocracia do Estado, com o setor mais importante da elite econômica do país, representado pela grande lavoura escravista, ou os "barões". ${ }^{41}$

Após encontrar resistências da parte de Itaboraí, representante por excelência destes "barões", e tendo alienado os liberais, o monarca apelou a dois membros da "facção

\footnotetext{
38 Ibid.

39 Cf. José Murilo de Carvalho, A construção da ordem e Teatro de sombras, p. 293.

40 Ibid., p. 231.

41 Ibid., "Os partidos políticos imperiais: composição e ideologia”, pp. 199-228.
} 
burocrática" do Partido Conservador, os viscondes de São Vicente e do Rio Branco, para a promoção de sua "política abolicionista". Sob os auspícios de d. Pedro, o estadista baiano assumiu a presidência do Conselho para promover a reforma emancipacionista, mas encontrou imensa resistência na Câmara para a realização de seu programa, traduzido num projeto que, longe de conter apenas disposições relativas à libertação dos nascituros, reorganizava e normatizava as relações entre escravos e senhores no país. ${ }^{42}$ Foi Paulino José Soares de Souza, filho do visconde do Uruguai e sobrinho de Itaboraí, quem encabeçou a formação de uma feroz dissidência veementemente contrária à medida proposta pelo governo.

A grande resistência não impediu a vitória do governo. Mas, ao promover uma política emancipacionista numa câmara unanimemente conservadora, contando com forte apoio dos magistrados que lá se encontravam, Rio Branco não apenas indispôs-se fortemente com os representantes da ala "vermelha" de seu partido, próximos à grande lavoura escravista do Centro-Sul, como incompatibilizou, entre si, as duas facções em que se dividiam os conservadores. $\mathrm{O}$ resultado teria sido profundamente derrisório para $\mathrm{o}$ próprio regime, pois a exposição da "artificialidade" da elite política imperial, isto é, a alta burocracia pertencente ao Partido Conservador, inabilitava-a para o papel que vinha cumprindo até então, de mediadora entre os setores agrários dominantes e os interesses do Estado. ${ }^{43}$ Fundamental para a cisão intra-elite e, portanto, para que as bases do regime fossem minadas, a incompatibilização dos dois grupos dominantes no partido que historicamente sustentara a tradição monárquica teria engendrado, então, uma grave crise de representatividade, ou melhor, a perda da percepção, por parte dos "barões", de que o Estado imperial era o mais adequado para atender seus interesses. ${ }^{44}$

Os efeitos derrisórios dos embates em torno da questão servil para a lógica partidária e para o sistema político geral do Império também ganham grande relevância na importante obra de Jeffrey D. Needell, que considera o ano de 1871 um momento decisivo de inflexão

42 Além de libertar o ventre das escravas, cujos filhos "ingênuos" poderiam ficar sob tutela dos proprietários de suas mães até atingirem a idade de 21 anos, ou, a partir dos 8 anos, ser entregues aos cuidados do Estado, a lei criou um fundo de emancipação nacional. Também de acordo com a lei que viria a ser aprovada, "pela primeira vez na história do Império, o escravo teve concedido o direito legal de guardar as economias (pecúlio) que tivesse reunido [...]. Com suas economias assim garantidas, o escravo viu-se assegurado o privilégio de comprar sua própria liberdade quando tivesse uma quantia em dinheiro igual a seu 'valor'". Cf. Robert Conrad, Os últimos anos da escravatura no Brasil: 1850-1888 ( $2^{\mathrm{a}}$ ed.), Rio de Janeiro: Civilização Brasileira, 1978, p. 113.

43 José Murilo de Carvalho, A construção da ordem e Teatro de sombras, "A política da abolição", pp. 291327.

44 Ibid., pp. 321-323. 
no processo de decomposição da relação entre a monarquia brasileira e suas bases de sustentação, iniciado na sua forma aguda três anos antes. ${ }^{45}$ Acompanhemos, rapidamente, a argumentação do autor.

De acordo com Needell, a característica mais importante da política do Segundo Reinado teria sido o crescimento do poder do Estado em detrimento da influência dos grupos que representavam as bases socioeconômicas do regime. Tal processo teria se traduzido no gradual e constante ganho de autonomia da Coroa frente aos partidos e ao próprio sistema representativo.

Após as lutas da regência e o Golpe da Maioridade, o monarca se voltara para um dos grupos em que haviam se dividido os liberais que fizeram a abdicação do primeiro imperador; aquele que, traumatizado pelas sangrentas rebeliões e guerras civis disseminadas pelo país durante a Regência, já se intitulava o "partido da ordem", e que viria a constituir a base do Partido Conservador. A ascensão ao poder garantiu aos “ordeiros" a possibilidade de moderar muitas das reformas realizadas durante a Regência. A subsequente derrota dos liberais mais "exaltados" nas revoltas da década de 1840 acabou engendrando um ganho de poder considerável aos conservadores e sua facção "ordeira", influente e organicamente ligada aos poderosos interesses da cafeicultura fluminense e sulmineira em aliança com a grande propriedade açucareira do Norte. Deste modo, homens como Bernardo Pereira de Vasconcelos, Itaboraí, Uruguai e Eusébio de Queirós puderam, em meados do oitocentos, iniciar a implantação de um projeto político para o país cuja essência seria a ideia de um regime monárquico constitucional representativo, politicamente centralizado e marcado por atribuições relativamente amplas da Coroa, mas limitadas por um Parlamento vigoroso. ${ }^{46}$

Contudo, afirma Needell, a cautela de d. Pedro II com relação ao facciosismo dos partidos adentrava, nesse mesmo período, uma nova etapa, e o processo de amadurecimento político do Imperador teria sido, nesse sentido, acompanhado por uma crescente percepção de que a integridade e consolidação do regime dependiam da moderação das tendências mais extremadas dos partidos, o que, por sua vez, teria como contrapartida a intervenção cada vez mais ativa do monarca no jogo político. A Conciliação e sua herdeira, a Liga Progressista, seriam, por essa interpretação, expressão

45 Cf. Jeffrey D. Needell, The party of order, cap. 6 "Abolition, war and the vindication of constitutional government: $1867-1871$ e cap. 7 "The defeat of the party: the political crisis of 1871".

46 Cf. Jeffrey D. Needell, "Formação dos partidos políticos no Brasil da Regência à Conciliação, 18311857". 
da ação mais interventora da Coroa, que patrocinou a formação de governos de coalizão entre os elementos moderados de ambos os partidos. Assim sendo, a queda do ministério Zacarias e o retorno do partido da ordem ao poder em 1868, sob os auspícios de São Cristóvão, teriam sido o ponto de inflexão nesses mal costurados arranjos. Isto porque tal evento, precipitado pela percepção da Coroa de que a vitória na Guerra da Tríplice Aliança dependia da permanência de Caxias no comando das tropas, desencadeou uma nova fase na relação do Imperador com os partidos e com as próprias bases de sustentação do regime. $^{47}$

A D. Pedro não seria possível resgatar o partido da ordem do relativo ostracismo em que havia caído, graças, em grande parte, à vontade do próprio Imperador, sem reinserir no jogo político as expectativas e projetos de tal grupo. A razão por trás dessa constatação advinha da própria origem dos chamados "vermelhos". Diferentemente dos governos de coalizão inspirados diretamente por São Cristóvão, eles possuíam raízes profundas na sociedade imperial, representando importantes interesses de classe. ${ }^{48}$ Por outro lado, ao apear Zacarias do governo utilizando-se claramente de seu poder pessoal, o Imperador "lançou a Liga Progressista para o campo liberal, tornando-a um radicalizado partido de oposição" ${ }^{49}$ As contradições dessa nova situação política, isto é, do embate entre a Coroa cada vez mais ciosa de suas amplas atribuições, os representantes de um projeto político essencialmente monárquico, mas limitador das prerrogativas do chefe do Estado em nome do bom funcionamento do sistema representativo e, correndo por fora, os liberais, cada vez mais radicalizados, que não poupavam os próprios alicerces do regime de virulentos ataques, se revelariam, com clareza, na batalha em torno de um tema fundamental ao país: a escravidão.

A queda da Liga teria significado que o Imperador perdia apoio no Executivo e no Legislativo para a realização de seu projeto "abolicionista", ao qual Zacarias e seus aliados haviam emprestado discreta adesão. Quando a Coroa chamou, ao poder, uma ala mais "pragmática" e menos "ideológica" do Partido Conservador para realizar a reforma servil, ${ }^{50}$ tornou-se evidente a Paulino de Souza e seus aliados que o Estado que os ordeiros

47 Cf. Jeffrey D. Needell, The party of order, cap. 6 "Abolition, war and the vindication of constitutional government: $1867-1871$ ".

48 Por exemplo: Ibid., pp. 231-3.

49 Cf. Jeffrey D. Needell, "Formação dos partidos políticos no Brasil da Regência à Conciliação", p. 22.

50 Segundo Needell, o Imperador não cogitou chamar ao poder os liberais, a quem caberia mais acertadamente o avanço de uma política emancipacionista, pois, após a inversão de 1868, eles, além de divididos, se demonstravam hostis ao monarca e seu "poder pessoal". Além disso, os conservadores 
ajudaram a construir e dirigir assumia "relativa autonomia nas mãos do monarca, que se voltou contra eles e seus interesses com um sucesso fatal". 51

Cientes da inevitabilidade da "abolição" patrocinada pelo Paço, o partido da ordem teria, naquele momento, adotado uma estratégia que consistia em apresentar um projeto de emancipação próprio, que mantivesse intactas, na medida do possível, a ordem constitucional e a ordem escravista. ${ }^{52}$ Nesse sentido, a resistência parlamentar ao emancipacionismo de São Cristóvão tinha como objetivo, em termos sintéticos, salvar a Coroa de si mesma. ${ }^{53}$

teriam preferido se manter no ministério, não obstante os prejuízos que tal opção poderia acarretar, a entregá-lo a seus opositores, opção muito mais arriscada, não apenas pelo perigo do reformismo liberal, mas também pelo receio do caos institucional decorrente de uma derrubada, com os expurgos e perseguições que as marcavam. Cf. Jeffrey D. Needell, The party of order, p. 267.

51 Cf. Jeffrey D. Needell, "Formação dos Partidos Brasileiros: questões de ideologia, rótulos partidários, lideranças e prática política, 1831-1888”, São Paulo, Almanack Braziliense (no 10), nov. 2009, p. 57. Acusando Rio Branco de trair o partido ao promover uma política emancipacionista que o próprio presidente do Conselho rejeitara pouco tempo antes, os "vermelhos" denunciaram a servilidade do ministério aos desejos da Coroa, bem como a ausência de apoio da opinião pública à medida cogitada, alertando seus pares quanto à ameaça que o desmonte da escravidão representava à ordem social. Mais do que tudo, destaca Needell, os dissidentes não se cansaram de apontar a gravidade da traição aos princípios constitucionais do Partido Conservador e às expectativas e interesses dos grupos sociais por ele representados. Cf. Jeffrey D. Needell, The party of order, pp. 287-288.

52 Ibid., pp. 290-2.

53 O projeto apresentado pelos dissidentes, segundo Needell, objetivava preservar a primazia da iniciativa legislativa parlamentar e impedir abalos na ordem social, priorizando a manutenção da autoridade senhorial ao conferir aos proprietários de escravos a prerrogativa de decidir quais cativos alforriar e sustentando a legitimidade do cativeiro. Não obstante, é possível sugerir, seguindo diferentes abordagens historiográficas, que o foco da oposição ao projeto emancipacionista do governo e a apresentação de um projeto alternativo que conferia aos senhores o poder de decisão sobre que escravos libertar estariam menos ligados à defesa de uma visão particular da organização e da divisão dos poderes do Estado do que à preocupação com a manutenção, intacta, da dinâmica social necessária à reprodução do sistema escravista. Ao interferir diretamente nas relações entre senhor e escravo, entre proprietário e "coisa" possuída, o Estado arrancava-as da esfera privada e introduzia um novo rol de possibilidades de questionamentos do escravizado com relação a seu cativeiro e da sociedade como um todo no que se referia à própria legitimidade do sistema escravista. Sob este ponto de vista, as ameaças aos interesses dos grupos sociais representados pelo partido da ordem parecem ainda mais palpáveis e imediatas. Nesse sentido, ver a obra de Joseli Maria Nunes Mendonça, Entre a mão e os anéis: a Lei dos Sexagenários e os caminhos da abolição no Brasil (2 $2^{\mathrm{a}}$ ed.), Campinas: Editora da Unicamp, 2008. Para a autora, a lei de 1871, ao permitir, por exemplo, que o escravo adquirisse sua própria liberdade por meio de pecúlio acumulado, transformava a questão da posse da liberdade, ensaiando um princípio profundamente ameaçador à ordem escravista: o de que a liberdade do escravo a ele pertencia, mas encontrava-se alienada nas mão de seu senhor. Uma interpretação distinta pode ser encontrada no clássico de Robert Conrad, op. cit. Nesta obra, o autor atribui à Lei do Ventre Livre um caráter eminentemente conservador, afirmando ser ela resultado da necessidade de preservação da escravidão, em decadência desde o estancamento da entrada de braços africanos advindo da proibição do tráfico atlântico, em 1850. Para Conrad, a intenção dos legisladores em 1871 teria sido "estabelecer um estágio de evolução para um sistema de trabalho livre sem causar grande mudança imediata na agricultura ou nos interesses econômicos", p. 113. Needell reconhece a importância de tais considerações para a oposição parlamentar, mas seguindo o caminho lógico de sua interpretação, é evidente que o autor advoga que a salvação do modelo de Estado construído sob o signo da Ordem prevalecia sobre quaisquer outras considerações dos dissidentes. Deste modo, a derrota de Paulino e seus aliados teve consequências desastrosas para si e para o Estado que se havia voltado contra eles. 
Seguindo a original interpretação de Needell, pode-se afirmar, portanto, que o rompimento da Coroa com a herança da "ordem" teria significado também seu rompimento com a própria lógica da monarquia constitucional representativa. Representantes dos interesses da classe sobre a qual se equilibrava a ordem imperial, os agora dissidentes teriam sido vítimas de seu próprio sucesso na construção de um Estado capaz de agir acima de interesses "facciosos". Deste modo, o fortalecimento do poder do monarca e do Executivo, em detrimento do sistema representativo cuidadosamente criado pela tradição ordeira e cujo ápice dataria de meados do oitocentos, alienou o apoio, ao regime, da classe dirigente que representava os interesses da elite agrária fluminense e da grande lavoura do Norte a ela ligada. A lei de 1871 teria sido, então, o ápice de uma "virada autoritária" do Estado imperial, ao mesmo tempo em que se iniciava seu processo final de decomposição.

Vimos acompanhado diferentes abordagens em torno dos sentidos de um período que a historiografia considera decisivo para os destinos da monarquia brasileira. É importante, neste momento, tecer considerações sobre o que foi exposto até aqui, tendo em vista os pontos de convergência e divergência que as interpretações estudadas possuem entre si, e o que eles podem nos dizer sobre a natureza da política imperial em suas décadas finais. Apesar das distâncias consideráveis, algumas aproximações em pontos fundamentais e interligados são possíveis de se realizar entre os autores citados.

Em primeiro lugar, pode-se articular o destaque dado ao poder pessoal do monarca com o papel central da Coroa no início da conjuntura crítica que viria a destruir o Império. Em segundo lugar, as fronteiras nebulosas entre os partidos políticos e a preeminência dos conservadores na construção do Estado imperial, considerando-se que, para dois dos autores citados, a derrota da dissidência conservadora em 1871 foi o ápice do processo que levou o regime à sua crise final. Em terceiro lugar, a inexistência ou insuficiência do sistema representativo por motivos diversos, intrinsecamente conectados aos fatores anteriormente citados.

A imperiosa centralidade do papel da Coroa se dá pela negação da existência de um sistema representativo autêntico. A percepção do vazio da nação, ${ }^{54}$ da ausência de "povo" (no sentido liberal do termo) ${ }^{55}$ ou do predomínio de um setor da elite como sustentáculo

54 Cf. José Murilo de Carvalho, A construção da ordem e Teatro de sombras.

55 Cf. Sérgio Buarque de Holanda, Do Império à República. 
das instituições ${ }^{56}$ são estruturais para a abordagem da falta de substância das instituições liberais no Brasil. Um simulacro que, para se sustentar, dependia da Coroa, não apenas cumprindo seu papel "moderador", mas também regulando e mediando as relações das facções que constituíam os partidos e intervindo ativamente em todos os aspectos da vida política do país. A “inversão partidária” de 1868 e a política emancipacionista adotada em 1871 são interpretadas como momentos críticos pelo fato de terem exposto a amplitude dos poderes reais e a resolução do monarca em passar a exercer suas atribuições de forma quase independente, comprometendo o simulacro representativo, bem como os interesses e a coesão dos setores da sociedade sobre cujos ombros o regime se apoiava. A preeminência tradicionalmente atribuída pela historiografia aos conservadores na construção e consolidação do Estado imperial, e o consequente ofuscamento ou marginalização dos liberais tende, por sua vez, a contribuir para que a relação entre o "partido da ordem" e o regime tenha importância fulcral na compreensão de quaisquer crises que vieram a se abater sobre o Segundo Reinado.

Até certo ponto, portanto, é possível afirmar que a historiografia até aqui estudada tende a abordar os vinte anos que separaram a crise de 1868 e o golpe de Estado republicano como um período de decadência e decomposição quase inexoráveis das instituições imperiais, ao mesmo tempo em que eram realizadas algumas das reformas e tomadas algumas das decisões mais relevantes na história do país. Reformas que vinham do topo, pois o sistema representativo é visto como trôpego e os partidos políticos são colocados, em geral, na posição de meros coadjuvantes na condução dos assuntos políticos. A Coroa, concentrando cada vez mais poderes em si, passaria a dispor dos homens de Estado para realizar uma agenda cada vez mais própria. Suas prioridades teriam dado o tom daquelas últimas décadas de grandeza e decadência. ${ }^{57}$

Deste modo, seguindo as interpretações citadas, pode-se, grosso modo, dividir temporalmente o Império do Brasil em três grandes períodos. O primeiro corresponde aos anos entre a Independência e o Golpe da Maioridade. Marcado pela centralização do Primeiro Reinado, pela resistência das elites nacionais em formação ao autoritarismo de d. Pedro I, por sua abdicação e pela instabilidade constante, especialmente na Regência, que se seguiu a sua queda, este teria sido um período de lutas intestinas e constantes conflitos

56 Cf. Jeffrey D. Needell, The party of order.

57 Cf. Sérgio Buarque de Holanda, Do Império à República; Roderick J. Barman, op. cit.; José Murilo de Carvalho, A construção da ordem e Teatro de sombras; Jeffrey D. Needell, op. cit. 
de caráter centrífugo ou separatista entre as elites regionais e o centro de poder do Estado, no Rio de Janeiro. Institucionalmente, o pós-abdicação, destaca a historiografia, foi marcado pela prevalência de um projeto liberal acentuadamente descentralizador consignado nas duas grandes reformas da primeira metade da década de 1830, o Código de Processo Criminal, de 1832, e o Ato Adicional, emenda constitucional efetivada a partir de 1834. Dada a percepção, compartilhada por setores crescentes da elite política imperial, de que o arranjo institucional dos anos 1830 havia contribuído sobremaneira para as turbulências da Regência, teria havido uma grande reação à descentralização instituída com as reformas citadas. Nos anos 1840, os setores mencionados, unidos no que ficou conhecido como Regresso, reformaram o Código de Processo e interpretaram o Ato Adicional, procurando tomar as rédeas do Estado, pacificando ou anulando as forças centrífugas que haviam ameaçado a unidade do Império do Brasil. Esse novo arranjo - que marca então o princípio do segundo grande período da política imperial -, iniciado com a ascensão dos regressistas ao poder, pouco depois da Maioridade de d. Pedro II, teria se consolidado a partir da derrota dos liberais nas revoltas da década de 1840 e o predomínio absoluto dos herdeiros do Regresso, a partir de então congregados no Partido Conservador. Essa consolidação teria marcado o início do apogeu do Estado imperial, cujo declínio se principiaria no momento do desfecho de um novo "golpe", também protagonizado pelo Imperador, cujos efeitos se fizeram sentir drasticamente a partir do triênio 1868-1871. A terceira fase do Império poderia ser localizada temporalmente, então, no intervalo entre esse triênio e o golpe republicano de 1889, momento em que a decomposição das instituições monárquicas se completou.

Recentemente, no entanto, uma parte da historiografia tem demonstrado reservas ou criticado ativamente essa visão geralmente consensual da história do Brasil monárquico. Destaca-se, nesse sentido, a obra de Miriam Dolhnikoff. Segundo a autora, o arranjo institucional da primeira metade da década de 1830 não foi superado ou revertido pelo chamado Regresso no início do decênio seguinte, mas perdurou por todo o regime. ${ }^{58} \mathrm{~A}$ opção dos liberais da Regência pela adoção de um pacto de tipo federativo constituiu um projeto de Estado próprio, vencedor sobre os desígnios autoritários do primeiro imperador e sobre o projeto reformista ilustrado centralizador, representado por figuras como os irmãos Andrada. ${ }^{59}$

58 Cf. Miriam Dolhnikoff, O pacto imperial: origens do federalismo no Brasil, São Paulo: Globo, 2005. 59 Ibid., cap. 1 "Projetos liberais". 
Diante da herança de uma América Portuguesa vasta e com interesses regionais díspares, o projeto liberal tinha como cerne o envolvimento das diferentes elites provinciais, dispersas ao longo de um território de dimensões continentais, na construção do Estado nacional. Esta opção também se mostrava imperativa tendo em vista a incapacidade dos braços da Corte em atingir as mais dispersas localidades, no sentido da sua integração ao novo país e da promoção da ordem legal, para a qual era essencial o reconhecimento geral da legitimidade do Estado brasileiro. Esse panorama de dispersão pôde ser, a altos custos, superado graças, especialmente, ao Ato Adicional de 1834. A emenda constitucional criou mecanismos para o exercício da autonomia provincial através da adoção de um pacto de tipo federativo em que se dividiam as competências entre centro e partes de modo a garantir às províncias ampla autonomia na gestão de seus próprios negócios, particularmente graças ao estabelecimento das Assembleias Legislativas Provinciais. ${ }^{60}$ Tal reconfiguração do Estado significou um pacto entre as elites políticas localizadas no centro e as elites dispersas pelo território que, ao constituírem-se em elites provinciais com direito a amplo controle sobre os negócios de suas províncias, comprometeram-se com a unidade e a estabilidade do Estado nacional. Essas elites provinciais puderam, então, cumprir um duplo papel: ao mesmo tempo em que se tornaram responsáveis pela disciplinarização e inserção dos potentados locais nos ritos formais do Estado liberal, passaram a representar o interesse de tais potentados, bem como de suas províncias, nos espaços legítimos de representação localizados na capital do Império, constituindo-se, assim, em elites nacionais. ${ }^{61}$ As reformas ditas "regressistas" da década de 1840 não teriam, para Dolhnikoff, significado, portanto, um rechaço do arranjo instituído no decênio anterior. Pelo contrário, foram a confirmação do triunfo do projeto liberal, com o aparamento de certas arestas e uma correção de rumos reivindicada por setores crescentes da elite política do país, especialmente no que dizia respeito ao Poder Judiciário e à divisão de competências entre Corte e províncias. ${ }^{62}$

60 Ibid., cap. 2 "O arranjo institucional".

61 Ibid., pp. 46-48 e 154.

62 Destarte, avalia Monica Dantas: "A competência provincial para legislar, tributar, dispor de uma força policial e controlar empregos provinciais e municipais (com exceção daqueles ligados ao judiciário) sem intervenção do governo central não foi alterada pela Interpretação [do Ato Adicional]. Da mesma forma, as elites provinciais continuaram contando com representantes na Câmara dos Deputados que se empenhavam na defesa dos interesses de suas províncias. A Interpretação resultou tão somente na alteração da estrutura do judiciário, sendo que algumas das medidas aprovadas foram fonte da discordância entre liberais e conservadores, enquanto outras eram reivindicadas por representantes das duas agremiações". Cf. Monica Duarte Dantas, "Partidos, liberalismo e poder pessoal: a política no Império do Brasil. Um comentário ao artigo de Jeffrey Needell, Formação dos partidos políticos no 
Nesse sentido, a essência do Estado formado a partir da abdicação de d. Pedro I estava na constante negociação entre as elites das diversas províncias, representadas por suas bancadas parlamentares e logo inseridas nos dois grandes partidos, Liberal e Conservador, que se nacionalizaram a partir da década de 1840. A contrapartida de tal arranjo era o caráter refratário das instituições imperiais a reformas estruturais, especialmente no que dizia respeito a questões de cunho social, sobressaindo-se a escravidão. ${ }^{63}$ Não obstante, esses limites não retiravam o conteúdo liberal das instituições imperiais nem comprometiam seu caráter representativo, apenas ressaltando uma predisposição à moderação e ao compromisso intra-elites em temas particularmente sensíveis, o que por sua vez não anulava a competição entre forças políticas com prioridades e ideologias distintas no que dizia respeito à condução do projeto de nação vencedor na primeira metade do oitocentos.

Diante do panorama apresentado pela original interpretação de Dolhnikoff, é possível, portanto, reavaliar diversos consensos historiográficos em torno dos temas acima destacados, como o caráter centralizado da monarquia brasileira e a prevalência da Coroa sobre as instituições representativas, na condição de árbitro supremo do conflito entre as “facções" e, nessa posição, de agente fundamental da reprodução do simulacro representativo, ou "ficção democrática", subsumindo e manipulando pelo seu poder irresistível a competição política entre os distintos setores da elite, presos a uma concreta vacuidade institucional, ocultada pela teatralização das instituições.

Contribuições ainda mais recentes vêm também ajudando a questionar algumas das proposições centrais de tais percepções da realidade político-institucional do Império. Em sua tese de doutorado, Sérgio Eduardo Ferraz, por exemplo, munido de ampla documentação e bibliografia de época, bem como da literatura clássica e mais recente sobre a política do período, propõe uma reavaliação do papel das instituições representativas e sua relação com a Coroa. ${ }^{64}$ Para isso, o autor perscruta as ligações entre os poderes Legislativo e Executivo através do estudo das causas das retiradas dos gabinetes.

Brasil da Regência à Conciliação, 1831-1857’. Almanack Braziliense. São Paulo, nº 10, nov. 2009, pp. 40-47.

63 Segundo a autora, “[o] sistema adotado no Brasil em 1834 significou, na sociedade escravista da época, a primazia dos interesses dos grupos regionais em detrimento de qualquer outro setor. Selava-se dessa forma a opção por um Estado excludente, do qual ficavam de fora escravos e trabalhadores livres pobres. Este arranjo, tal qual implementado no Brasil, tornava extremamente difícil, às vezes impossível, a inclusão de uma pauta de reformas sociais na agenda política". Cf. Miriam Dolhnikoff, O pacto imperial, p. 295.

64 Cf. Sérgio Eduardo Ferraz, op. cit. 
Conforme os dados apresentados por Sérgio Ferraz, a maior parte das mudanças ministeriais ao longo de todo o Segundo Reinado foi causada por atritos com a Câmara dos Deputados, sendo que a Coroa teria sido diretamente responsável pela substituição dos governos em relativamente poucas ocasiões. Além disso, abordando temas fundamentais à configuração político-insitucional do Estado e seu funcionamento, como as questões ligadas ao orçamento e ao sistema eleitoral, o autor demonstra o vigor do Parlamento e sua proeminente participação na proposição e implementação de reformas e na sanção de meios necessários à administração estatal. Deste modo, para Ferraz, por relevante que tenha sido a atuação da Coroa, por meio do exercício do Poder Moderador, para o “equilíbrio da política imperial”, ela "se processou, efetivamente, em interação com outros atores e dinâmicas institucionais - os quais podem ter funcionado como importantes constrangimentos e condicionantes nesse processo". ${ }^{65}$ Assim, a consolidação das instituições imperiais após as reformas das décadas de 1830 e 1840 foram essenciais para a organização do Estado, sua legitimação junto aos diversos grupos regionalmente relevantes e a inserção de tais grupos, através dos partidos políticos nacionalizados, nas instituições representativas localizadas na Corte, onde lidavam ao mesmo tempo com as demandas dos seus representados nas províncias e aquelas características do exercício de um mandato a nível nacional, no qual se conflagravam, dentro dos espaços legítimos de negociação, diferentes projetos e expectativas para o país. Nesse sentido, destaca o autor:

A consolidação de um sistema partidário em todo o território do Império, seus nexos com as lideranças provinciais, detentoras de competências e representações próprias, e a estruturação progressiva de regras parlamentares, regendo a sobrevivência dos gabinetes, sugerem que a Coroa, ao exercitar suas prerrogativas, deparou-se com atores e instituições relevantes, os quais retiravam sua força, para além dos respectivos enraizamentos societários, dos dispositivos legais discutidos acima - estes últimos ricos em consequências, em termos de incentivos emergentes, nem sempre antecipadas pelos implicados no processo político. Dentre esses atores e instituições, ressaltam-se os partidos, as elites provinciais e a Câmara dos Deputados. Mesmo amplas, como de fato eram, as possibilidades de exercício do poder político por parte da Coroa não se efetuaram, assim, em um vazio político institucional, mas interagiram com outras forças e estiveram submetidas, muito provavelmente, a uma série de constrangimentos derivados de regras e dispositivos, formais e informais, cristalizados no sistema. ${ }^{66}$

Em outra contribuição recente, Paula Ribeiro Ferraz problematiza, ao estudar o

65 Ibid., p. 41.

66 Ibid., p. 41. 
gabinete da Conciliação, a suposta prevalência dos conservadores "vermelhos" no arranjo político-institucional do Império. ${ }^{67}$ Segundo a autora, os gabinetes conservadores do quinquênio 1848-1853, geralmente tratados pela historiografia como símbolos máximos da hegemonia "saquarema" na política de então, ${ }^{68}$ tiveram que lidar, na verdade, com profundas e extensivas divisões no Partido Conservador, expressadas primordialmente pela formação de amplas e ferozes oposições, cujas fontes de descontentamento tinham relação tanto com assuntos provinciais quanto com questões de interesse nacional. Segundo a autora, ao ter de lidar com a nova realidade de um Partido Conservador nacionalizado, em que as demandas das heterogêneas bancadas provinciais se impunham, os gabinetes da metade do oitocentos encontraram grandes dificuldades. ${ }^{69}$

Essas oposições recém-formadas foram capazes de se articular, enquanto vozes crescentes de diferentes cores políticas passavam a defender um compromisso entre as forças heterogêneas representadas no Parlamento, para que assim se pudesse lidar com a nova realidade em que se encontrava a representação nacional, diante da crescente inclusão de atores distintos no arranjo político-institucional em processo de consolidação. ${ }^{70}$ Assim sendo, o período conhecido como Conciliação não teria sido fruto da intervenção ativa do monarca, nem tampouco rejeição ou continuação da política dita "saquarema", mas sim a convergência de uma série de fatores que envolviam compromissos em torno de reivindicações e expectativas que datavam, em grande parte, já da década anterior, com a participação de diversos atores que viram na ascensão do prestigioso Honório Hermeto Carneiro Leão um meio de avançar uma agenda de compromisso diante do deslocamento e reposicionamento das forças políticas. ${ }^{71}$

Debruçando-se, portanto, sobre abordagens historiográficas recentes, é possível rediscutir e recolocar em pauta diversas questões fundamentais para a compreensão do funcionamento do Estado monárquico no que se refere à sua esfera político-institucional. Tais abordagens tendem a indicar que não apenas não houve a propalada supremacia de um elemento singular na vida política do país, ora a Coroa, ora o Partido Conservador,

67 Cf. Paula Ribeiro Ferraz, op. cit.

68 São apontados como símbolos de tal hegemonia, especialmente, o ministério Monte Alegre, de 8 de outubro de 1849, que contava com Eusébio de Queirós na pasta da Justiça e encerrou o tráfico atlântico de escravos, e o primeiro ministério Rodrigues Torres, de 11 de maio de 1852. Cf. Barão de Javari, Organizações e programas ministeriais; regime parlamentar no Império ( $3^{\mathrm{a}}$ ed.). Brasília: Departamento de Documentação e Divulgação, 1979, pp. 104-112.

69 Cf. Paula Ribeiro Ferraz, op. cit., pp. 41-56.

70 Ibid., pp. 56-62.

71 Ibid., cap. 2 "O Gabinete da Conciliação entre os ministerialistas e a oposição". 
como ela não se afastava de maneira drástica das vicissitudes que então caracterizavam os sistemas constitucionais representativos de cunho liberal em grande parte do mundo ocidental. Nesses termos, mais do que encarar a crise de 1868 como o início da decomposição das instituições monárquicas, a partir do desvelamento do poder sobranceiro da Coroa ou da incompatibilização desta com sua base de sustentação fundamental na sociedade de então, parece conveniente encetar a compreensão da reorganização políticopartidária engendrada pelo fim da Liga Progressista e de que forma as forças ativamente envolvidas na condução do debate e dos negócios públicos se rearticularam frente a um novo contexto, que ia além das sensíveis mudanças no panorama da alta política.

No contexto mencionado, o tema da reorganização político-institucional do Estado ganhou relevância fundamental, em querelas que envolviam tanto a readequação do sistema representativo, para a qual o sistema eleitoral era fundamental, quanto a extensão dos direitos políticos, com a essencial discussão acerca da expansão da cidadania. Ligada inexoravelmente a ambas as querelas, estavam as disputas em torno da ampliação das franquias provinciais, com aumento ou não da autonomia, foco de intensos conflitos nos anos então vindouros. Mais do que isso, a historiografia tem indicado que a política imperial sofreu uma considerável inflexão a partir da transição entre as décadas de 1870 e 1880. Nesse período, com as mudanças estruturais pelas quais passavam a economia e a sociedade imperiais, tendo na ascensão do abolicionismo militante uma expressão importante, houve o advento de um processo de popularização da política do Império, em que amplas camadas até então formalmente excluídas dos processos decisórios passaram a tecer demandas crescentemente radicalizadas, exigindo o reconhecimento de suas reivindicações pela elite política imperial. As instituições monárquicas tiveram que reagir a esse novo estado de coisas e encontrar respostas que não existiam até então. ${ }^{72}$

Nesses termos, a presente dissertação privilegia o estudo dos dois grandes partidos monárquicos, suas dinâmicas internas, seus projetos e de que forma lidaram com a nova realidade política do Império em seus anos derradeiros. Tendo como referência fundamental dois temas, centrais ao longo de toda a duração do regime, mas que ganharam uma gravidade ímpar no período crítico de que se trata aqui - a saber, no campo eminentemente político, a questão eleitoral, e no campo social, mas também de amplo

72 Cf. Sandra Lauderdale Graham, "O Motim do Vintém e a cultura política do Rio de Janeiro, 1880", in: Monica Duarte Dantas (org.), Revoltas, motins, revoluções: homens livres pobres e libertos no Brasil do século XIX, São Paulo: Alameda, 2011, pp. 485-510; Maria Helena Pereira Toledo Machado, O plano e o pânico: movimentos sociais na década da abolição (2ª ed.), São Paulo: Edusp, 2010, p. 138. 
alcance político, a questão servil, além de um terceiro, inexoravelmente conectado aos citados, e ao qual a historiografia recente vem dando mais atenção, isto é, o processo de popularização da política e de crescente pressão pela "democratização" da sociedade imperial, testemunhado especialmente a partir da década de 1880 -, pretende-se aqui indicar caminhos para compreensão do impacto desses rearranjos, reposicionamentos, novos atores e elementos inesperados no sistema partidário do Império, bem como os sentidos e significados embutidos nas repostas que a elite política imperial encontrou diante desse contexto particularmente crítico. Desta forma, a título introdutório, cabem duas inquirições iniciais importantíssimas para o presente estudo. Em primeiro lugar, se a característica essencial das instituições representativas imperiais era a negociação e o acordo intra-elites na condução dos assuntos vitais para o país, ${ }^{73}$ de que modo o advento de movimentos sociais reivindicatórios e de demandas crescentes pela expansão da participação política colocou em xeque ou exigiu o rearranjo de tal modelo? Em segundo lugar, como a sensível alteração do sistema eleitoral, com a adoção de eleições diretas por distritos uninominais, impactou o funcionamento das instituições representativas, a economia interna dos partidos políticos e a própria condução dos negócios do Estado? Estas duas interrogações guiarão as seções seguintes do presente capítulo.

\section{2 - Partidos e eleições: as disputas em torno do sistema eleitoral e a opção pela eleição direta}

Temas fundamentais para a organização do Estado liberal, entre eles a separação de poderes, a definição das prerrogativas das distintas esferas de governo (com a divisão de competências entre centro, províncias e municípios) e a extensão dos direitos políticos, estavam diretamente ligados à normatização do sistema eleitoral, motivo de constantes e intensas polêmicas ao longo da existência da monarquia brasileira. Deste modo, nos quase 70 anos em que existiu o Império do Brasil, especialmente a partir do advento do Segundo Reinado, foram diversos as reformas, regulamentos e instruções concernentes ao sistema eleitoral. Tais diplomas e documentos materializavam projetos distintos para o país, apresentando clivagens significativas, diretamente relacionadas às prioridades dos grupos políticos no poder quando de sua aprovação.

A Constituição de 1824 continha uma série de disposições que constituíram a base do

73 Cf. Miriam Dolhnikoff, O pacto imperial. 
sistema eleitoral no Império. Segundo a Carta outorgada, as eleições deveriam se realizar de forma indireta, com os votantes de $1^{\circ}$ grau selecionando os eleitores de $2^{\circ}$ grau que, por sua vez, sufragariam os representantes da nação. Os artigos constitucionais diretamente ligados aos pleitos não eram muitos. Além do artigo 45, que dispunha sobre os requisitos necessários para que um cidadão pudesse candidatar-se ao Senado, outros oito artigos tratavam do assunto. Eram eles:

Art. 90. As nomeações dos Deputados e Senadores para a Assembleia Geral, e dos Membros dos Conselhos Gerais das Províncias, serão feitas por Eleições indiretas, elegendo a massa dos cidadãos ativos em Assembleias Paroquiais os Eleitores de Província, e estes os Representantes da Nação, e Província.

Ar. 91. Têm voto nestas Eleições primarias

I. Os Cidadãos Brasileiros, que estão no gozo de seus direitos políticos.

II. Os Estrangeiros naturalizados.

Art. 92. São excluídos de votar nas Assembleias Paroquiais

I. Os menores de vinte e cinco anos, nos quais se não compreendem os casados e Oficiais Militares, que forem maiores de vinte e um anos, os Bacharéis Formados, e Clérigos de Ordens Sacras.

II. Os filhos famílias, que estiverem na companhia de seus pais, salvo se servirem Ofícios públicos.

III. Os criados de servir, em cuja classe não entram os guarda-livros, e primeiros caixeiros das casas de comércio, os Criados da Casa Imperial, que não forem de galão branco, e os administradores das fazendas rurais, e fábricas.

IV. Os Religiosos, e quaisquer que vivam em Comunidade claustral.

V. Os que não tiverem de renda líquida anual cem mil réis por bens de raiz, indústria, comércio, ou Empregos.

Art. 93. Os que não podem votar nas Assembleias Primarias de Paróquia, não podem ser membros, nem votar na nomeação de alguma Autoridade eletiva Nacional ou local.

Art. 94. Podem ser Eleitores e, votar na eleição dos Deputados, Senadores e Membros dos Conselhos de Província todos, os que podem votar na Assembleia Paroquial. Excetuam-se

I. Os que não tiverem de renda líquida anual duzentos mil réis por bens de raiz, indústria, comércio ou emprego.

II. Os Libertos.

III. Os criminosos pronunciados em querela ou devassa.

Art. 95. Todos os que podem ser Eleitores, hábeis para serem nomeados deputados. Excetuam-se

I. Os que não tiverem quatrocentos mil réis de renda líquida, na forma dos Arts. 92 e 94.

II. Os Estrangeiros naturalizados.

III. Os que não professarem a Religião do Estado.

Art. 96. Os Cidadãos Brasileiros, em qualquer parte que existam, são elegíveis em 
cada Distrito Eleitoral para Deputados, ou Senadores, ainda quando aí não sejam nascidos, residentes ou domiciliados.

Art. 97. Uma Lei regulamentar marcará o modo prático das eleições, e o número dos Deputados relativamente à população do Império. ${ }^{74}$

Após as instruções de 1824, que sucederam a promulgação da Constituição e normatizaram e organizaram os pleitos subsequentes, ${ }^{75}$ a primeira peça legislativa relevante referente às eleições foi o regulamento eleitoral de 1842, decretado durante o segundo gabinete da Maioridade, quando do retorno dos regressistas ao ministério, e que tinha como principal objetivo a revisão das reformas liberais datadas da Regência. ${ }^{76} \mathrm{Com}$ a Interpretação do Ato Adicional e, especialmente, a reforma do Código de Processo Criminal, que promoveram uma considerável centralização do Poder Judiciário, foram criados os cargos de Chefe de Polícia, delegado e subdelegado, diretamente submetidos aos presidentes das províncias, ligados, por sua vez, à Corte.

O regulamento eleitoral aprovado pelos regressistas, já num momento de transição ao que se tornaria o Partido Conservador, criou a qualificação prévia dos votantes e eleitores, realizada pelas juntas de qualificação, formadas pelo "Juiz de Paz do distrito em que estiver a [igreja] Matriz, como Presidente; do Pároco, ou quem suas vezes fizer; e de um Fiscal, que será o Subdelegado, que residir na Paróquia, ou o imediato Suplente deste no seu impedimento". ${ }^{77}$ Isto significava, antes de tudo, a existência de um agente do governo central influindo diretamente na qualificação do eleitorado. Se tal alvitre não constituiu uma ampla centralização do controle sobre as eleições, permitiu uma maior intervenção do ministério nos pleitos, o que demonstrava uma preocupação típica do Regresso em atribuir às autoridades provinciais, especialmente àquelas ligadas ao centro, um papel relevante o bastante para contrabalançar aquele exercido pelos poderes locais. ${ }^{78}$

A lei $\mathrm{n}^{\mathrm{o}} 387$, de 19 de agosto de 1846, por sua vez, atuou num sentido diferente. ${ }^{79}$ Além de reajustar o censo da constituição, a partir de então computado em prata, a

74 Constituição Política do Império do Brasil - Jurada a 25 de março de 1824. In: Adriano Campanhole e Hilton Lobo Campanhole, Todas as constituições do Brasil, São Paulo: Atlas, 1971.

75 Para o Decreto de 26 de março de 1824, ver: Francisco Belisário Soares de Souza, O sistema eleitoral no Império. Brasília: Senado Federal, 1979, pp. 187-200.

76 Decreto $\mathrm{n}^{\mathbf{o}}$ 157, de 4 de maio de 1842, in Ibid., pp. 201-207.

77 Ibid., p. 201.

78 As Mesas Paroquiais, que conduziam as eleições primárias e tinham como função reconhecer a identidade dos votantes, receber as cédulas e zelar pela ordem no pleito, continuavam sendo nomeadas por votação do eleitorado local, podendo compô-la apenas eleitores de $2^{\mathbf{o}}$ grau. Ibid., p. 204.

79 Ibid., pp. 208-232. 
legislação promulgada durante o "quinquênio liberal", mais especificamente sob o ministério 2 de maio, descentralizou consideravelmente o sistema eleitoral.

A medida criou juntas de qualificação de votantes presididas pelo "Juiz de Paz mais votado no distrito da Matriz" na eleição mais recente, “esteja ou não em exercício, esteja embora suspenso por ato do Governo ou por pronúncia em crime de responsabilidade". 80 Os outros quatro membros da junta seriam escolhidos localmente, entre eleitores de $2^{\circ}$ grau e suplentes. ${ }^{81}$ Para a eleição secundária, o procedimento previsto seria similar, com o presidente da mesa interina do Colégio Eleitoral sendo o juiz de paz mais votado da “Assembleia Paroquial da Freguesia onde se reunir o Colégio, e na falta ou impedimento, o seu imediato em votos". ${ }^{82}$ Esse "presidente interino" nomearia os quatro eleitores mais jovens presentes para serem secretários e escrutinadores da mesa interina, que realizaria a eleição do presidente da mesa que efetivamente conduziria o pleito. Este presidente, por sua vez, nomearia seus secretários e escrutinadores. ${ }^{83}$

Pode-se perceber diferenças sensíveis, portanto, entre a lei de 1846 e as instruções de quatro anos antes. Segundo as disposições da lei promulgada durante o "quinquênio liberal”, a qualificação dos votantes e a condução dos pleitos seria realizada totalmente por figuras eleitas na localidade, enquanto que, no caso das instruções, datadas do primeiro gabinete regressista, as qualificações tinham não apenas a presença fiscalizadora do subdelegado, funcionário ligado diretamente ao governo central mas também definiam que apenas um dos membros das juntas qualificadoras, o juiz de paz, seria figura eleita localmente. ${ }^{84}$

Alguns pontos importantes levantados durante a discussão da lei eleitoral de 1846 não foram adiante naquele momento, tendo sido preteridos ou adotados de forma restrita. Dois deles, as disposições sobre incompatibilidades eleitorais e a distritalização das

80 Ibid., p. 208. Caso o juiz de paz mais votado não comparecesse, a lei dispunha que faria "as suas vezes o imediato em votos".

81 Ibid., p. 210.

82 Ibid., p. 221.

83 O Art. 70 da lei dispunha: "Constituída a Mesa interina, se procederá à nomeação de dois Secretários e dois Escrutadores, em escrutínio secreto, votando cada Eleitor em 4 nomes. Os dois mais votados serão os Secretários, e os outros dois Escrutinadores. Os nomeados tomarão logo assento na mesa, e imediatamente se passará a nomear o Presidente, por escrutínio secreto, e por cédulas, dentre os Eleitores; e apurados os votos pelos Secretários e Escrutadores, será eleito e publicado o que reunir a pluralidade relativa. Tomando o novo Presidente posse, em ato sucessivo, nomeará uma comissão de 3 Eleitores, a qual entregarão os seus Diplomas os Mesários, tomando estes conta dos Diplomas de todos os outros Eleitores". Ibid., p. 221.

84 A lei de 1846 ainda possuía algumas disposições interessantes, pois conferia elegibilidade para o cargo de vereador das câmaras municipais aos votantes. Ibid., p. 218 e 222. 
circunscrições eleitorais, foram adotados nove anos depois, pelo Decreto $\mathrm{n}^{\circ} 842$, de 19 de setembro de 1855. Tais medidas estavam previstas em projeto da autoria do liberal Francisco de Paula Souza e foram recuperadas durante o gabinete da Conciliação, presidido pelo Marquês de Paraná, que contava com ampla sustentação parlamentar dos liberais. $^{85}$

Até então, as eleições no Império eram realizadas tendo as províncias como circunscrições eleitorais. ${ }^{86}$ Isto significava que, para ser eleito, um deputado não poderia ser uma figura reconhecida e influente apenas localmente. Mesmo se fosse amplamente votado no município onde exercia sua influência diretamente, o candidato precisava garantir votos em toda a província. Isto favorecia a eleição de grandes lideranças, políticos com capacidade de negociar e fazer circular seu nome por toda a extensão de suas províncias, o que, na prática, excluía líderes mais locais. ${ }^{87}$ A partir da lei de 1855 , as novas circunscrições eleitorais passaram a ser distritos de um só deputado, isto é, cada província se dividiria em um número de distritos igual à sua bancada parlamentar, e cada distrito elegeria um deputado. O impacto de tal alteração no modelo eleitoral era de longuíssimo alcance.

Como aponta Paula Ribeiro Ferraz, foi intenso o conflito político ocasionado, na década de 1850 , pela iniciativa do voto distrital, ou por "círculos", ${ }^{88} \mathrm{O}$ principal argumento de seus defensores era que tal modelo possibilitaria uma representação mais fiel do país e contrabalançaria a influência das elites provinciais e do governo do Rio de Janeiro nos pleitos eleitorais. Seus detratores, por outro lado, destacavam que tal modelo permitiria que as chamadas "notabilidades de aldeia", homens sem nenhum preparo ou "ilustração", adentrassem o Parlamento, diminuindo a respeitabilidade da representação nacional, já que tais homens, por sua inexperiência e falta de musculatura política, seriam incapazes de compreender os autênticos interesses nacionais. Os apologistas do voto provincial

85 Cf. Paula Ribeiro Ferraz, op. cit., p. 121. Sobre o primeiro ponto, as incompatibilidades eleitorais, a lei definia que magistrados e funcionários públicos não poderiam ser candidatos a cargos eletivos nas localidades em que exerciam seus cargos e poderiam, por meio deles, influenciar de forma indesejável os pleitos. Dispunha o $\S 20$ do Art. $2^{\circ}$ da lei: "Os Presidentes de Província e seus Secretários, os Comandantes de Armas e Generais em Chefe, os Inspetores de Fazenda Geral e Provincial, os Chefes de Polícia, os Delegados e Subdelegados, os Juízes de Direito e Municipais, não poderão ser votados para Membros das Assembleias Provinciais, Deputados ou Senadores nos Colégios Eleitorais dos Distritos em que exercerem autoridade ou jurisdição. Os votos que recaírem em tais empregados serão reputados nulos". Cf. Francisco Belisário Soares de Souza, op. cit., p. 237.

86 Era um "majoritarismo provincial", onde o eleitor tinha "tantas opções quantas fossem as vagas existentes para a unidade provincial no Legislativo". Cf. Sérgio Eduardo Ferraz, op. cit., p. 229.

87 Ibid., p. 246.

88 Cf. Paula Ribeiro Ferraz, op. cit., pp. 113-130. 
destacavam a importância, num tom acentuadamente oitocentista, de que a representação nacional fosse composta por homens de reconhecida ilustração, que, qualificados e "virtuosos", garantiriam que o interesse geral tivesse preeminência frente aos poderes locais. ${ }^{89}$ Mais do que discussões sobre o melhor sistema eleitoral, estavam em pauta em tais debates diferentes modelos de representação, pois os defensores do voto distrital uninominal esposavam um projeto descentralizador e focado no enfraquecimento da direção das elites provinciais e nacionais, promovendo uma transformação significativa na lógica partidária do Império e ampliando a competição eleitoral. ${ }^{90}$

A lei dos distritos uninominais foi aprovada em fins de 1855, mas regulou apenas uma eleição para a câmara temporária, em 1857. De fato, em pouco tempo, ela passou a ser questionada no Parlamento e, após longos embates e dificuldades encontradas, decidiu-se, já no início da década de 1860, por uma espécie de compromisso entre os dois extremos. Uma nova reforma eleitoral manteve o voto distrital, mas ampliou os distritos, que passaram a contar com três deputados. ${ }^{91}$ Conforme Miriam Dolhnikoff, tal solução foi aventada por parecer responder às preocupações de ambos os partidos, pois, ao mesmo tempo em que "favoreciam a escolha de representantes considerados melhor qualificados para definir o interesse geral", com os distritos maiores também "se procurava garantir a representação das minorias, considerada inviável pelo voto provincial". 92

As circunscrições provinciais foram restabelecidas pela reforma eleitoral de 20 de

89 Cf. Miriam Dolhnikoff, "Representação na monarquia brasileira”, Almanack Braziliense, São Paulo, $\mathrm{n}^{\circ}$ 9, mai/2009, pp. 49-50.

90 Cf. Paula Ribeiro Ferraz, op. cit., pp. 122-130. Miriam Dolhnikoff coloca o problema em termos claros: "Nesse debate, além da questão concreta da disputa política, estavam em jogo duas concepções distintas de representação. Os defensores do voto distrital fundamentavam seu projeto com uma ideia de representação baseada na semelhança, segundo a qual o bem comum nasceria no seio do debate da Assembleia se os representantes fossem uma espécie de microcosmo da sociedade, se cada um deles fosse uma espécie de espelho daqueles que representavam. Isto só seria possível se fossem escolhidos por um universo pequeno de eleitores, o distrito. [...] Do debate e da negociação obrigatória para se chegar a um acordo surgiriam as decisões que refletissem o interesse nacional. Os críticos do voto distrital sustentavam, por sua vez, uma concepção de representação que advogava a eleição dos mais capazes, dos mais virtuosos entre os cidadãos, os mais ilustrados, pois esses eram os representantes habilitados para definir o bem comum". As eleições em circunscrições provinciais, transcendendo o "poder local", seriam o meio de selecionar este último tipo de representante. De acordo com a autora, a primeira visão, distrital, descentralizadora, "se aproxima da perspectiva defendida pelos federalistas norte-americanos", enquanto a segunda remetia àquela concebida por Edmund Burke. Cf. Miriam Dolhnikoff, "Governo representativo e legislação eleitoral no Brasil do século XIX". Journal of Iberian and Latin American Research, v. 20, 2014, pp. 66-82.

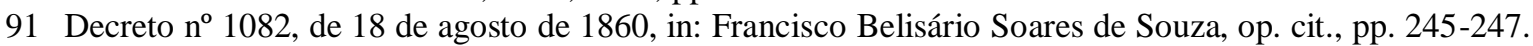
Além disso, a lei, entre outras disposições, tornou mais amplas e rígidas as incompatibilidades eleitorais, incluindo os juízes de órfão e determinando que aqueles funcionários que não deixassem seus cargos seis meses antes de uma eleição, não poderiam se candidatar no distrito em que exercessem sua função.

92 Cf. Miriam Dolhnikoff, "Representação na monarquia brasileira", p. 51. 
outubro de $1875 .{ }^{93}$ Denominada Lei do Terço, a reforma promulgada pelo gabinete conservador chefiado pelo duque de Caxias, e que tinha como principal ministro o barão de Cotegipe, almejava garantir a representação das minorias sem a adoção do voto direto, já amplamente defendido à época. Para isso, os eleitores de $2^{\circ}$ grau deveriam escolher os nomes que comporiam, no máximo, dois terços da bancada da província no ramo temporário do Poder Legislativo, teoricamente garantindo um terço dos assentos ao partido de oposição.

A lei, objetivando coibir fraudes, adotou, ainda, a qualificação permanente dos votantes, que receberiam um título que os habilitava a votar nas eleições seguintes sem precisarem passar por novo processo de qualificação. ${ }^{94}$ Por outro lado, suas disposições devolveram, a autoridades ligadas ao governo central, influência considerável na qualificação eleitoral. Os membros das juntas de qualificação ainda seriam eletivos, em pleitos presididos pelos juízes de paz, mas a lista feita por essa junta seria verificada e apurada por uma junta municipal, presidida pelo juiz municipal, no município em que residisse, ou pelo substituto do juiz de direito, e composta por "dois membros eleitos pelos Vereadores da Câmara" daquele município. ${ }^{95}$ Cabia ainda recurso, em casos de irregularidades e "vícios" nas qualificações, ao Juiz de Direito e à Relação do Distrito. ${ }^{96}$

Pelo que foi exposto até aqui, portanto, é possível entrever que o modelo de realização das eleições foi intensamente debatido e alterado pelos parlamentares ao longo de todo o período de duração do Império do Brasil. Segundo Miriam Dolhnikoff, entre os temaschave ligados à construção do Estado brasileiro que guiavam a atuação dos políticos do período, estava a edificação de um sistema político sólido e socialmente legítimo que, num contexto em que o liberalismo se consolidava no Ocidente, tinha de ser necessariamente constitucional e representativo. ${ }^{97}$ Desta forma, a normatização das eleições era fundamental para o sucesso da grande obra de construção e consolidação do novo Estado liberal. A autora destaca, então, quatro temas que "mobilizaram os parlamentares brasileiros" ao longo de toda a duração do regime monárquico no que dizia respeito à

93 Decreto $n^{\circ}$ 2675, de 20 de outubro de 1875, in: Francisco Belisário Soares de Souza, op. cit., pp. 248-265.

94 Ibid., pp. 255-256.

95 Entre a extensa gama de atribuições conferidas às juntas municipais, estava "apurar e organizar definitivamente, por paróquias, distritos de paz e quarteirões, a lista geral dos votantes do município, com a declaração dos que são elegíveis para eleitores [...]." Competia, ainda, a elas incluir pelo conhecimento que tivessem, ou pelas provas exibidas de capacidade política, "os cidadãos cujos nomes houverem sido omitidos" e excluir "os que tiverem sido indevidamente qualificados pelas juntas paroquiais" [...]. Ibid., pp. 252-253.

96 Ibid., pp. 254-255. A lei também retirou dos votantes a elegibilidade ao cargo de vereador. Ibid., p. 262.

97 Cf. Miriam Dolhnikoff, "Representação na monarquia brasileira". 
arquitetura eleitoral do país: a definição dos direitos de cidadania, a fraude eleitoral, a representação das minorias e o combate à influência do Executivo nas eleições. ${ }^{98}$ As respostas e soluções aventadas a essas preocupações compartilhadas eram, contudo, diversas e variavam de modo considerável entre os distintos setores da elite política representados no Parlamento, nos diferentes contextos em que os projetos de reforma chegavam à ordem do dia.

Como pudemos entrever, por meio da pequena síntese realizada no início do presente subcapítulo, as reformas sustentadas por liberais, particularmente as realizadas nos anos de 1846 e 1855, tiveram caráter descentralizador, privilegiando as localidades em detrimento das elites políticas provinciais e nacionais, enquanto que as reformas realizadas durante a vigência de situações conservadoras, particularmente o regulamento de 1842 e a Lei do Terço, caminharam no sentido oposto, reforçando a autoridade dos chefes de partido nas províncias e no centro e dos magistrados ligados à Corte. Se a reforma eleitoral de 1860 foi algo próximo a um compromisso entre as duas tendências, a Lei do Terço, de 1875, reestabelecendo as circunscrições provinciais com a manutenção do sufrágio indireto, parece ter sido a tentativa de setores do Partido Conservador em aprimorar a representação das minorias, uma das principais bandeiras dos defensores do voto distrital, ao mesmo tempo em que reabilitavam as circunscrições provinciais.

No entanto, como foi exposto na seção anterior do presente capítulo, não obstante a existência de tais clivagens significativas e acirradas disputas em torno de sua implementação, relevantes interpretações historiográficas tendem a considerar o sistema representativo do Brasil imperial como um "simulacro" ou "ficção". 99 Todas as discussões sobre o sistema eleitoral, nos termos de tais interpretações, não teriam se traduzido num efetivo enfrentamento dos vícios políticos do país, calcado na centralidade do "poder pessoal" $" 100$ ou na dependência da legitimidade da alta burocracia do Estado, ligada ao Partido Conservador, na mediação entre os interesses da grande propriedade exportadora e aqueles da Coroa. ${ }^{101} \mathrm{Em}$ todo caso, o falseamento eleitoral, as fraudes e violências constantes eram lembretes incômodos de que a alternância das "facções" no poder, representadas pelos partidos políticos, sempre dependia, em última instância, do

98 Ibid., p. 48

99 Destacam-se, entre outras, as obras clássicas de José Murilo de Carvalho, A construção da ordem e Teatro de sombras e Sérgio Buarque de Holanda, Do Império à República.

100 Cf. Sérgio Buarque de Holanda, Do Império à República

101 Cf. José Murilo de Carvalho, A construção da ordem e Teatro de sombras. 
beneplácito e da intervenção da Coroa e dos homens a ela ligados e submetidos. ${ }^{102}$ Assim, tende-se a abordar a movimentação em torno da reforma eleitoral que culminaria na chamada Lei Saraiva, ${ }^{103}$ com a adoção da eleição direta, como uma última tentativa de introduzir alguma "verdade" no sistema representativo do país, num contexto em que a crise do regime monárquico já seria uma realidade amplamente reconhecida. Conforme tal interpretação, a última alternativa política à decomposição do regime teria sido o reconhecimento formal da ausência de "povo", ou de que o "país real" se reduzia a uma pequena porcentagem da população brasileira do período, inscrito numa lei supostamente restritiva no que dizia respeito aos direitos políticos.

Destarte, o crescimento do apoio à eleição direta ao longo da década de 1870 é abordado como consequência da profunda crise de legitimidade que se abateu sobre as instituições imperiais após as inflexões políticas ocorridas entre fins dos anos 1860 e princípios do decênio seguinte. Para Sérgio Buarque de Holanda, a gradual aceitação de tal recurso nos círculos da alta política foi acompanhada pela capitulação do Imperador, que, apesar de não reconhecer no país condições ideais para o novo modelo de sufrágio, teria dado seu consentimento à reforma, após tomar consciência de que a própria sobrevivência da "ficção democrática", colocada sob especial risco depois da inversão partidária de 1868, estaria em jogo. ${ }^{104}$ José Murilo de Carvalho, por sua vez, considera que o novo compromisso em torno da eleição direta, firmado entre as "facções" que compunham a política imperial, teria surgido com grande força após as duras batalhas de 1871, quando os representantes dos "barões" derrotados pelo Imperador e seus homens de confiança atentaram para a necessidade de recuperar, na medida do possível, as rédeas do processo político. $^{105}$

Os dois autores priorizam, então, ao abordar a lei de 1881, dois pontos, entre suas diversas disposições, que comprovariam seu caráter excludente, destinado a reconhecer a realidade de um país "plebeu", mas de "timbre aristocrático", ${ }^{106}$ ou salvar o "teatro" que era a política imperial, retirando de cena a multidão de figurantes - os votantes - que

102 Nesse sentido, segundo José Murilo de Carvalho, era a ação da Coroa que, ultimamente, possibilitava o bipartidarismo e a representação das minorias. "Em sua ausência", assevera o autor, "dificilmente haveria conflito regulado. Ou o conflito seria extralegal, ou seria suprimido mediante arranjos de dominação como o que se desenvolveu na República Velha, com a criação dos partidos únicos estaduais". Ibid., p. 406.

103 Decreto no 3029, de 9 de janeiro de 1881, in Francisco Belisário Soares de Souza, op. cit., pp. 335-369.

104 Cf. Sérgio Buarque de Holanda, Do Império à República, pp. 176-242.

105 Cf. José Murilo de Carvalho, A construção da ordem e Teatro de sombras, pp. 391-416

106 Cf. Sérgio Buarque de Holanda, Do Império à República, pp. 176-242. 
sobrecarregavam as encenações eleitorais periódicas, cada vez mais desastradas. ${ }^{107} \mathrm{O}$ processo de debate e aprovação da última reforma eleitoral do Império se mostra, assim, revelador da crescente indistinção entre os dois grandes partidos monárquicos, ou ao menos dos setores majoritários desses partidos. A eleição direta teria encontrado sua contrapartida necessária, que no limite pouco dependeria do partido responsável por levála a cabo, no sacrifício dos direitos políticos da maior parte da população, culpabilizada pela corrupção e violência que marcavam os pleitos, e na consequente "aristocratização" do eleitorado, por meio do apelo à "ilustração" e "independência" dos cidadãos habilitados a votar.

Cabe notar que tais interpretações são geralmente bastante influenciadas por relatos e críticas ao sistema eleitoral do Império, realizados por contemporâneos e informados, obviamente, por suas posições político-partidárias. Entre eles, destaca-se Francisco Belisário Soares de Souza, cuja mais ilustre obra, O sistema eleitoral no Império, tem avalizado muitas das interpretações sobre o tema e acerca dos próprios significados da Lei Saraiva, curiosamente posterior ao escrito. ${ }^{108}$

Belisário, que era um conservador fluminense da ala mais dura, ou "vermelha", do partido, publicou a obra citada no ano de 1872, quando da derrota de seus aliados na luta contra a Lei do Ventre Livre. Na publicação, Belisário não poupou o sistema representativo do Império de acerbas críticas, responsabilizando a corrupção, fraudes e intervenções indevidas nos pleitos eleitorais, incapazes de realmente expressar a vontade do "país real", pelo deplorável estado de coisas. Nesse sentido, o autor atribuía a responsabilidade pelos "maus hábitos eleitorais" ao governo, por um lado, que intervinha ativamente nos pleitos, e, principalmente, à figura do votante, que o político conservador considerava o principal empecilho a eleições realmente representativas.

Sujeito à manipulação e submetido a interesses escusos, o votante seria homem geralmente simplório e ignorante de questões que ultrapassassem seus interesses mais imediatos, o que deixava seu voto à disposição dos poderes econômicos e políticos que dominassem a localidade onde vivia:

O votante pode ser um homem ilustrado e importante; mas não é este o votante em cujo poder está decidir as eleições primárias, porque nelas os votos se contam pelo número e não pela qualidade. Os votantes são a grande massa arrolada nas listas de

107 Cf. José Murilo de Carvalho, A construção da ordem e Teatro de sombras, pp. 391-416. 108 Cf. Francisco Belisário Soares de Souza, op. cit. 
qualificação, a turbamulta, ignorante, desconhecida e dependente. O votante é, por via de regra, analfabeto; não lê, nem pode ler jornais; não frequenta clubes, nem concorre a meetings, que os não há; de política só sabe do seu voto, que ou pertence ao $\mathrm{Sr}$. fulano de tal por dever de dependência (algumas vezes também por gratidão), ou a quem lho paga por melhor preço, ou lhe dá cavalo, ou roupa a título de ir votar à freguesia. ${ }^{109}$

Deste modo, a defesa da eleição direta realizada por Belisário significava a extinção da figura legal do votante, tendo como consequência a exclusão de uma imensa parcela da população até então apta a exercer certos direitos políticos, mesmo que restritos à escolha dos eleitores de $2^{\circ}$ grau. Àqueles cujas objeções à eleição direta baseavam-se na crítica à possível privação do direito ao voto de um imenso número de cidadãos, Belisário redarguia utilizando-se de um expediente argumentativo baseado na negação do voto como direito. Para o autor, não havia direitos adquiridos quando se tratava de funções sociais, "cujo exercício pressupõe certas condições de capacidade". Entre elas estaria o voto, que não constituiria direito natural, sendo legítimo que, do exercício de tal "faculdade", fossem privados certos cidadãos que pudessem, por meio dela, mesmo que inconscientemente, ferir e prejudicar a sociedade em que viviam. Tais restrições à capacidade eleitoral dos que não fossem realmente "capazes" configuravam, então, caso de "justiça social". Se o direito do votante era, na realidade, "um direito ineficaz, precário, que nada garante, que nenhuma vantagem, regalia ou importância social confere", não havia equívoco em sua exclusão dos pleitos, pois a efetiva participação nos negócios públicos deveria estar restrita àqueles que tivessem condições reais de carregar tal fardo e estivessem dispostos a realizar árduos sacrifícios em nome da "boa governança” do país, já que votar seria "antes um dever social do que o gozo de um direito". 110

A exclusão dos votantes seria, então, uma necessidade para o aprimoramento do sistema eleitoral. As "massas populares", turbulentas e sem instrução, não deveriam ter acesso a um direito político que era também dever cívico ligado ao bem público e ao correto funcionamento do Estado. Na verdade, a indiferença política dessas "massas", aqui sinônimo dos votantes de então, quanto aos interesses que não fossem privados e imediatos, por si só deveria afiançar sua exclusão do corpo eleitoral. Por isso, admoestando o que chamou de "escola ultra-democrática, vítima eterna de absurdas e extravagantes ilusões", Belisário condenou, de forma peremptória, a expansão do sufrágio como solução aos

109 Ibid., p. 33.

110 Ibid., pp. 115-116. 
problemas políticos do país:

As massas populares, alternadamente indiferentes ou apaixonadas e desvairadas, serão sempre o instrumento cego de todos os despotismos e nunca a base segura e sólida em que repousa o edifício trabalhoso e delicado do governo constitucional representativo, única forma, até hoje possível, da verdadeira liberdade. A eleição neste regime é a origem de toda a direção social; dela saem os legisladores, os fiscais o governo; dela emanam e nela fenecem todos os poderes sociais. Não é das trevas, da ignorância, das abusões, das paixões selvagens e brutais que surgirá o reinado da razão e da justiça na sociedade. ${ }^{111}$

A visão de Belisário, por ter sido amplamente difundida, é geralmente tratada como ilustrativa da movimentação geral das forças políticas pelas eleições diretas e, mais ainda, como comprovação do problema da fraude e manipulação endêmicas nas eleições do país. Deste modo, a avaliação desabonadora que fazia do sistema eleitoral do Império e as soluções, excludentes e politicamente enviesadas, que propunha para sua "moralização" e consequente recuperação da legitimidade do sistema representativo, são respaldadas sem a realização de uma crítica documental que o recoloque no seu contexto histórico e atente para sua posição social e filiação partidária.

Se é verdade que Francisco Belisário esposava um projeto político marcadamente excludente, um "parlamentarismo aristocrático", 112 é também verdade que, primo de Paulino de Souza e um dos líderes da ala dos antigos "saquaremas" do Partido Conservador, ele era representante direto da grande lavoura escravista do Rio de Janeiro, o que significa que sua análise da política imperial e as expectativas expressadas em sua importante obra eram informadas por tal posição. ${ }^{113}$ Nesse sentido, parece necessário

111 Ibid., p. 131. Por outro lado, o conservador fluminense defendia severas disposições concernentes às incompatibilidades eleitorais, que seriam fundamentais para a exclusão da magistratura da representação nacional, diminuindo sobremaneira a influência do Executivo no Parlamento, e gerando um ganho considerável de autonomia para o Poder Legislativo.

112 Cf. Christian Edward Cyril Lynch, O Momento Monarquiano. O Poder Moderador e o pensamento político imperial. Tese de Doutorado em Ciência Política, Rio de Janeiro: IUPERJ, 2007. Seguindo a interpretação de José Murilo de Carvalho, o autor considera que a disseminação da adesão à eleição direta no Império estava, fundamentalmente, na promoção da "política abolicionista" por parte do monarca. O movimento "suprapartidário" da grande lavoura em direção a um sistema representativo mais autêntico, em que um "parlamentarismo aristocrático" dispensaria a constante intervenção da Coroa nos negócios públicos, tinha como fim, para Lynch, "tomar o Estado de assalto". Nesse sentido, essa "institucionalização da defesa de seus interesses correspondia a uma evidente 'reação da classe proprietária rural à inevitável redefinição do papel da agricultura' posta pela perspectiva da abolição da escravatura", p. 357.

113 Roberto Saba, em artigo no qual discute e reavalia a percepção das eleições no Brasil oitocentista como eminentemente inautênticas e marcadas pela simples manipulação unilateral, já observou ser necessária uma crítica constante aos relatos, frequentemente utilizados pela historiografia, da autoria de “personagens como João Francisco Lisboa, Nabuco de Araújo, Francisco Belisário, José de Alencar e 
indagar até que ponto o "aristocratismo" dos projetos de eleição direta não estava, na verdade, restrito apenas a um, ou alguns, setores da elite política imperial, ganhando o tema vieses distintos na pena ou na oratória de estadistas pertencentes a outros grupos políticos.

Sem atentar a tais diferenças fundamentais, tende-se a turvar as fronteiras programáticas e ideológicas existentes entre os dois grandes partidos políticos, e mesmo entre os diferentes grupos que os compunham, com prioridades e expectativas também fincadas nos interesses das províncias que representavam. ${ }^{114}$ Desta feita, afasta-se a defesa da eleição direta das disputas políticas que efetivamente ocorreram ao longo de todo o regime em torno da legislação eleitoral, disputas que estavam imbuídas de expectativas distintas para o país e esposavam modelos conflitantes de organização do Estado.

Ao tomar-se, assim, a eleição direta como última resposta à agonia do Estado imperial, que partia, indistintamente, de todos os setores da elite política que ainda desejavam salválo, desconsidera-se as imensas dificuldades, renhidos conflitos e intrincadas negociações que precederam a instalação dos pleitos de grau único no país, que se materializaram em uma peça legislativa cujas disposições envolviam temáticas e efetivavam projetos que se encontraram em disputa ao longo de toda a duração do regime, preterindo outros. Tendo em vista tais considerações, parece necessário reavaliar o ambiente político e o processo decisório que permitiram o sucesso da eleição direta.

A queda do Partido Conservador, dez anos depois da inversão partidária de 1868, e a ascensão do Partido Liberal, rearticulado na oposição ao longo daquele decênio, na figura do novo presidente do gabinete ministerial, João Lins Vieira Cansanção de Sinimbu, são geralmente abordadas na historiografia pelo viés da urgência da eleição direta. "Vencido, mas não convencido", o Imperador teria cedido às intensas pressões e crescente aceitação do fim da eleição em dois graus pelos dois partidos constitucionais. Frente ao insucesso da

Tavares Bastos, todos eles homens profundamente envolvidos na vida política de seu tempo". Do contrário, "[a]o tomarem as descrições dos agentes históricos como simples relatos do processo eleitoral, os analistas deixam de notar que estes textos eram utilizados como armas nas disputas partidárias da época". No mesmo sentido, utiliza-se aqui o livro de Francisco Belisário como fonte historiográfica, tendo em vista ser a expressão de um projeto político-partidário muito bem alinhavado. Cf. Roberto N. P. F. Saba, "As 'eleições do cacete' e o problema da manipulação eleitoral no Brasil monárquico", Almanack. Guarulhos, n. 02, $2^{\circ}$ semestre de 2011, p. 129.

114 Nesse sentido, a defesa do voto distrital aparecia como uma alternativa ao predomínio absoluto das bancadas das grandes províncias no Parlamento, "quebrando" sua coesão e, assim, garantindo "maior fôlego de negociação no parlamento para os representantes das províncias menores". Cf. Miriam Dolhnikoff, "Governo representativo e legislação eleitoral no Brasil do século XIX".

115Por exemplo, Sérgio Buarque de Holanda, Do Império à República, pp. 185-187; Roderick J. Barman, op. cit., pp. 408-410; Christian Lynch, op. cit., p. 352. 
Lei do Terço, "que não dera bons frutos", especialmente por não garantir a representação das minorias como prometera, ${ }^{116}$ e à doença do duque de Caxias, então presidente do Conselho, o monarca teria decidido devolver o poder aos liberais. A opção pela inversão partidária teria sido, para Sérgio Buarque de Holanda, motivada por duas considerações: a primeira se referia ao longo ostracismo do Partido Liberal, que estava havia dez anos longe do poder; a segunda estaria ligada ao fato de ter sido este partido o primeiro a pugnar pela reforma. $^{117}$

Por sua vez, a opção por Sinimbu para a presidência do Conselho, em detrimento de estadistas liberais mais célebres e mais ligados ao programa da eleição direta, como Nabuco de Araújo, estaria vinculada, para o referido historiador, ao desejo que possuía o monarca em manter na chefia do governo um político dependente de sua confiança e a quem pudesse "fiscalizar", o que seria tarefa inglória em se tratando de estadistas da envergadura e prestígio do pai de Joaquim Nabuco. ${ }^{118}$ No cerne de sua escolha, estaria sua já citada má vontade e desconfiança com relação à eleição direta, que considerava ser realizável apenas por vias de reforma constitucional, modelo que Sinimbu aceitava. Ao atentar-se à documentação, contudo, é possível realizar algumas considerações sobre os eventos de fins da década de 1870.

A Fala do Trono de $1878^{119}$ e a apresentação do ministério Sinimbu ao Senado demonstram que o novo gabinete chegou ao poder tendo a reforma eleitoral como parte fundamental do programa. ${ }^{120}$ Contudo, a recepção hostil do presidente do Conselho na câmara alta era indicativa das imensas dificuldades que lhe aguardavam.

116 Cf. Sérgio Buarque de Holanda, Do Império à República, p. 184; Christian Lynch, op. cit., p. 351.

117 A morte de Zacarias de Góis, irreversivelmente incompatibilizado com a Coroa, no ano de 1877, teria, segundo o autor, pesado para a decisão de D. Pedro. Cf. Sérgio Buarque de Holanda, Do Império à República, pp. 185-186. Para Roderick Barman, a decisão de chamar de volta ao poder os liberais teria marcado o início de uma nova fase no governo do Imperador, em que este se mantinha, cada vez mais, "na defensiva, não mais o mestre de todos os assuntos da nação", sendo que, gradativamente, deixava de ser considerado, pelos súditos, como "indispensável”. Cf. Roderick J. Barman, op. cit., pp. 410-411. Os programas liberais lançados após a inversão partidária de 1868 já propunham a adoção da eleição direta. O programa radical, lançado naquele mesmo ano, defendia "sufrágio direto e generalizado", enquanto que aquele lançado pelo Partido Liberal no ano seguinte pretendia "Eleição direta na Corte, Capitais das Províncias, e cidades que tiverem mais de 10 mil almas, as quais constituirão distritos eleitorais por si sós com as freguesias que dentro delas se compreendem". Cf. Américo Brasiliense de Almeida e Melo, op. cit., pp. 31-40.

118 Cf. Sérgio Buarque de Holanda, Do Império à República, p. 186.

119 Anais da Câmara dos Deputados (em diante, ACD). 15/12/1878, pp. 92-93.

120 Anais do Senado (em diante, AS). 19/12/1878, pp. 9-22. "Conquanto reconhecesse as gravíssimas circunstâncias do país, e bem avaliasse as dificuldades de realizar a missão, que me era confiada, entendi que não devia recusá-la, tanto em obediência à ordem da Coroa, como porque tratava-se de promover a reforma eleitoral direta, ideia iniciada pelo partido liberal, e hoje reclamada como essencial para o regular andamento do nosso sistema representativo", declarou o chefe do gabinete à câmara vitalícia. 
As recriminações, que partiram tanto de conservadores quanto de liberais, destacavam a inocuidade das explicações oferecidas pelo chefe do gabinete acerca da inversão partidária. Tais explicações se focaram no fato de que, após ficar evidente a impossibilidade de seguir à frente do ministério anterior o duque de Caxias, por conta de grave enfermidade, teriam sido convocados ao Paço os presidentes da Câmara dos Deputados e do Senado, respectivamente, Paulino de Souza e o visconde de Jaguari, para responderem a consulta do monarca acerca da situação conservadora e da possibilidade do partido realizar a reforma da eleição direta. ${ }^{121}$ Segundo o próprio Imperador, a despeito de ambos terem afirmado ter a medida ampla aceitação no Partido Conservador, e sugerirem ser possível a organização de uma nova formação ministerial com tal programa, sem troca da situação, o monarca, justificando ter sido o Partido Liberal o primeiro a pugnar por tal reforma, decidiu, então, chamar Sinimbu para organizar o gabinete. ${ }^{122}$

O senador conservador pelo Paraná, Manuel Francisco Correia, ${ }^{123}$ estranhou a explicação dada pelo presidente do Conselho, que, em linhas gerais, seguia exatamente a justificativa da precedência dos liberais no que dizia respeito à eleição direta. Segundo ele, se ambos os partidos políticos aceitavam, geralmente, a eleição direta, não fazia sentido atrasar-se sua realização mudando-se a situação, tendo sido opção mais sensata entregar o poder ao estadista que mais rapidamente poderia consegui-la, fosse Paulino de Souza, fosse Jaguari. Inclusive porque nenhum deles desejando reforma constitucional, pugnando pela adoção da eleição direta por vias parlamentares ordinárias, teriam mais facilidade, diante de uma Câmara de maioria conservadora, em aprová-la do que um gabinete liberal, que dependeria de, ao menos, uma dissolução e convocação de duas eleições para realização de uma Constituinte.

Para o liberal representante de Goiás, José Inácio Silveira da Mota, ${ }^{124}$ só se justificaria a ascensão de Sinimbu, se este apresentasse ao Parlamento um programa explícito para a realização da reforma eleitoral, não palavras vazias e genéricas sobre a necessidade da eleição direta, que, além de tudo, contrariavam a posição da maior parte de seus correligionários, favoráveis à reforma sem Constituinte. Só se compreenderia a inversão

121 As informações são do barão de Cotegipe, que como principal ministro do gabinete demissionário justificava sua retirada ao Senado. Ibid., pp. 9-11. O relato é corroborado, documentalmente, por Roderick J. Barman, op. cit., p. 410.

122 As palavras do Imperador, em carta a Caxias, foram as seguintes: "Portanto ambos os partidos a desejam [a reforma eleitoral] e eu não tenho senão que achá-la oportuna, entendo que deve ser o partido liberal, que primeiro e constantemente tem pugnado por ela, que o faça”. Apud Ibid., p. 410.

123 AS. 19/12/1878, pp. 11-13.

124 Ibid., pp. 13-16. 
partidária, se Sinimbu especificasse em que pontos os partidos estavam em desacordo, deixando claro que seu programa não seria a mera eleição direta, mas uma reforma eleitoral realizada de acordo com as expectativas do Partido Liberal. Apenas a imposição da Coroa explicava a aceitação da reforma constitucional pelo presidente do Conselho, pois, "se a organização do atual ministério fosse feita regularmente, com o acordo de seus amigos políticos", o programa de Sinimbu seria completamente distinto:

Veja agora o senado se tenho ou não razão de achar deficientes tanto a resposta dos ministros que saíram como a dos que entraram! Estes falam em eleição direta, mas não dão ideia da eleição que querem... Pode ser uma eleição muito corcundatica!

$[\ldots]$

Os nobres ministros disseram que fizeram o compromisso...

O Sr. Silveira Lobo: - De privar o país de um direito, de que está de posse há 53 anos.

O Sr. Silveira da Mota: - ... de fazer o cumpre que decreteis, ${ }^{125}$ e isto sem consultar a vontade de seus amigos políticos, porque, repito, estou convencido de que, se o atual ministério consultasse a opinião de seus amigos políticos, não havia de querer sacrificar uma câmara eleita por este último processo vicioso, para fazer eleger uma constituinte pela mesma lei, por esse mesmo processo vicioso.

Que espera o nobre presidente de uma constituinte eleita de conformidade com a própria lei eleitoral que S. Ex. condena, como a condena todo o país? (Apoiados). ${ }^{126}$

Um projeto de Constituinte, para Silveira da Mota, só se justificaria se esta tivesse ampla liberdade para reformar o sistema político do Império, inclusive as prerrogativas do Poder Moderador e a vitaliciedade do Senado. ${ }^{127}$ Nos termos em que fora apresentado, remetendo apenas a um projeto vago de reforma eleitoral, representava apenas sujeição aos desígnios do "Altíssimo".

O isolamento de Sinimbu parece ter ficado claro ao presidente do Conselho bem antes de sua apresentação ao Parlamento. Ao menos é o que indica seu profundo pesar com a recusa de José Antônio Saraiva, principal liderança liberal após os falecimentos de Zacarias de Góis e Nabuco de Araújo, em compor o ministério. "[U]ma das maiores contrariedades que tenho tido na vida política", a negativa do senador baiano, ainda no início de 1878, teria feito Sinimbu renunciar à “tarefa que impensadamente aceitei não fora

$125 \mathrm{O}$ senador fazia referência às palavras da Fala do Trono, em que se declarou: "Reconhecida a necessidade de substituir o sistema eleitoral vigente pelo de eleição direta, cumpre que a decreteis mediante reforma constitucional [...]". ACD. 15/12/1878, p. 92. O "cumpre que decreteis" foi utilizado por mais de um senador, nas acusações desferidas contra o ministério, como simbólico seu caráter "corcundático" e seu desprezo pelas prerrogativas do Parlamento.

126 AS. 19/12/1879, p. 15.

127 Ibid., p. 16. 
a tamanha responsabilidade em que me achei perante nosso partido". ${ }^{128}$

Deste modo, não parece exata a proposição de que o Senado recusou o alvitre da reforma constitucional por corporativismo ou pela afinidade de seus membros com os desejos da Coroa. Pelo contrário, as falas e atitudes dos senadores, antes mesmo da apresentação do projeto Sinimbu ao Parlamento, sugerem que era contra a intervenção do Poder Moderador na reforma eleitoral que protestavam os senadores que defendiam a eleição direta, independentemente do partido a que pertenciam. ${ }^{129}$ Se se afiguram acertadas as sugestões de Sérgio Buarque de Holanda sobre a escolha de Sinimbu pela Coroa, em detrimento de lideranças mais destacadas, como um chefe de gabinete mais dócil e dependente, não parece ter sido apenas contra a exclusão do Senado na consecução da lei, prevista no caso de reforma constitucional, que os estadistas da câmara vitalícia se colocavam, mas ao fato de que tal processo deixava à Coroa grande influência nos termos da reforma. Isto porque, como confessara o próprio Sinimbu, a aprovação da lei eleitoral "por meio de reforma constitucional" poderia depender de seguidas dissoluções da Câmara dos Deputados, ${ }^{130}$ o que, por sua vez, colocaria o Poder Moderador na condição de árbitro supremo da reforma. Se, ao menos, o ministério desse sinais de que haveria uma Constituinte ampla, com plenos poderes para atuar em várias direções, como indicou Silveira da Mota, ela poderia contar com o apoio de setores do Partido Liberal que desejavam amplas reformas, mas as perspectivas inscritas no programa do gabinete iam de encontro a tal possibilidade, pois se apresentavam claramente restritivas.

É possível, portanto, que, para além do fracasso da Lei do Terço, que deve ter desgostado fortemente os liberais pelas suas disposições centralizadoras e pelo restabelecimento do voto provincial, a ascensão de Sinimbu tenha se dado por seu comprometimento com a reforma constitucional, defendida pelo monarca, mas pouco aceita entre importantes lideranças conservadoras e, ao menos com as severas limitações apresentadas, também entre liberais, com destaque, no primeiro caso, para Paulino de Souza, que fora preterido, e, no segundo, Saraiva, que não aceitara tomar parte no gabinete organizado por seu correligionário alagoano.

Por outro lado, não parece irrelevante a declaração feita, em aparte, pelo senador

128 João Lins Vieira Cansanção de Sinimbu a José Antônio Saraiva, 06/01/1878. AIHGB. Col. Saraiva, DL 270.37, doc. 9.

129 O próprio Cotegipe voltou à tribuna para tecer críticas à inversão partidária e a proposta de Constituinte. AS. 19/12/1878, pp. 16-19. 130 Sinimbu a Saraiva, 06/01/1878. AIHGB. Col. Saraiva, DL 270.37, doc. 9. 
liberal Francisco de Paula da Silveira Lobo, de que "[n]essa reforma [eleitoral], o principal é o censo; aí consiste toda a reforma". ${ }^{131}$ Ora, Paulino de Souza, como outras importantes figuras de seu partido, defendia a adoção da eleição direta sem Constituinte, mas com o censo do eleitor e a manutenção das condições impostas, na lei fundamental, aos eleitores de $2^{\circ}$ grau. ${ }^{132}$ Isto significava, antes de tudo, a retirada de direitos políticos de cidadãos ativos que, conforme a Constituição, tinham apenas a condição de votantes, tais como os libertos. Tal expediente, por meio de lei ordinária, poderia ser acusado de inconstitucional, deslegitimando toda a reforma. Deste modo, se o Imperador não aceitava eleição direta sem alteração da Constituição, isto é, sem a intervenção ativa do Poder Moderador, e se, ao mesmo tempo, desejava restrições ao eleitorado, ${ }^{133}$ fazia sentido apelar a um político liberal que aceitasse o encargo, desde que se comprometesse com um projeto por vias constitucionais. Havia, ainda, mais obstáculos à realização da reforma pelos conservadores, pois uma minoria deste partido, liderada pelo visconde do Rio Branco, ${ }^{134}$ não aceitava a eleição direta e, caso um projeto Paulino chegasse ao Senado, poderia ser derrotado por uma coligação entre tal grupo e os liberais. Se podemos considerar, então, que o monarca teria feito um cálculo político bastante acertado, a inversão partidária, ademais, poderia angariar, à augusta vontade, o apoio do partido na câmara vitalícia que, junto de parcelas do Partido Conservador mais ligadas à Coroa, teria números para aprovar a reforma constitucional na casa. Se esta foi a estratégia do Imperador para a consecução de uma reforma que contemplasse suas opiniões, ela foi atacada sem tréguas, como vimos, desde antes de o Parlamento tomar contato com a proposta da reforma eleitoral do novo ministério.

131 AS. 19/12/1878, p. 12.

132 Ainda quando ministro dos Negócios do Império, sob o gabinete Itaboraí de 1868, Paulino de Souza apresentara, a seus colegas no ministério, um projeto de eleição direta, que encontrou, apesar da aprovação de Cotegipe e do próprio visconde de Itaboraí, respostas divididas. Segundo Christian Lynch, o "projeto Paulino criava o alistamento permanente de eleitores, introduzia a eleição direta, adotava o censo literário e elevava o pecuniário [...]. Para ele, nenhuma reforma conseguiria acabar com a manipulação do governo, caso não organizasse um eleitorado seleto e independente, livre da 'turba multa, ignorante, desconhecida e dependente'.” Cf. Christian Lynch, op. cit., p. 349.

133 O Imperador criticava, por exemplo, a ampliação de direitos aos não católicos e desejava que o censo eleitoral fosse ajustável pela inflação. João Ferreira de Moura a José Antônio Saraiva, Rio de Janeiro, 13/03/1880. AIHGB, L. 274. P. 31. Apud Guo-Ping Mao, Homens e cousas in the age of reform, Brazil, 1868-1889, Tese de Doutorado em Filosofia apresentada à Universidade do Texas em Austin, 1997; Roderick J. Barman, op. cit., p. 420.

134 Segundo Angela Alonso, as posições de Rio Branco eram fortemente avessas às eleições diretas. Afirma a autora que, para o senador conservador, "a superioridade do sistema indireto estaria em hierarquizar a participação dos cidadãos ativos sem os inconvenientes da 'soberania do número', 'que a falta de discernimento em muitos poderia causar', se eles tivessem de escolher imediatamente os mandatários da nação". Cf. Angela Alonso, Ideias em movimento: a geração de 1870 na crise do Brasil-Império, São Paulo: Paz e Terra, 2002, p. 89. 
O projeto defendido pelo gabinete Sinimbu era sucinto. Nele previa-se a dissolução da legislatura então em funcionamento e a convocação de novo pleito, no qual o eleitorado conferiria mandatos especiais a seus representantes diretos para reformarem cinco artigos da Constituição do Império que normatizavam o sistema eleitoral, mais precisamente, os artigos 90 a 94, acima citados:

A assembleia geral legislativa decreta:

Artigo único - Os eleitores dos deputados para a seguinte legislatura lhes conferirão nas procurações, especial faculdade para reformarem os artigos da constituição que se seguem:

Os artigos 90, 91, 92 e 93, para o fim de serem as nomeações dos deputados e senadores para a assembleia geral, e dos membros das assembleias legislativas provinciais, feitas por eleição direta.

O artigo 94, para o fim de só poderem votar os que sabendo ler e escrever, tiverem por bens de raiz, capitais, indústria, comércio ou emprego, a renda líquida anual que for fixada em lei, nunca inferior a quatrocentos mil réis. ${ }^{135}$

Diversos membros do Partido Liberal na Câmara dos Deputados criticaram acidamente o projeto. Ecoando as palavras de Silveira da Mota, no Senado, José Bonifácio de Andrada e Silva, o Moço, ${ }^{136}$ cunhou a célebre expressão "Constituinte constituída", como uma denúncia pública às restrições previstas, no projeto, à ação do Parlamento. ${ }^{137}$ A razão disto era que, de acordo com o parlamentar paulista, o governo previa uma Assembleia Constituinte alijada de reais poderes e exclusivamente convocada para ratificar o que previamente se acordasse; ou seja, a seus membros caberia reformar docilmente os artigos constitucionais que se apresentavam como empecilhos às eleições diretas, ainda sob o peso de uma disposição pré-determinada que equiparava o novo censo eleitoral ao antigo censo do eleitor (e não do votante, como queriam diversos parlamentares), ao mesmo tempo em que excluía a massa de analfabetos da possibilidade de participar da escolha de seus representantes.

As divisões em torno de pontos importantes do projeto foram sentidas no próprio núcleo do governo e alguns membros do gabinete não demoraram a romper com Sinimbu. O ministro da Fazenda, Gaspar da Silveira Martins, prestigioso político riograndense,

135 ACD. 13/02/1879, p. 492.

136 José Bonifácio, o Moço, como era conhecido, deputado e depois senador por São Paulo, herdara o nome de seu tio-avô, o Patriarca da Independência. Cf. Augusto Victorino Sacramento Blake, Diccionario bibliographico brazileiro, Rio de Janeiro: Conselho Federal de Cultura, 1970, v. 4, pp. 350-351. 137 ACD. 28/04/1879, pp. 747-762. 
abandonou sua pasta dias antes da apresentação da proposta à Câmara dos Deputados. ${ }^{138}$ Segundo indica a documentação, os motivos de Silveira Martins estavam no profundo descontentamento com a "política de sujeição" que adotava o ministério em relação à Coroa, ${ }^{139}$ compartilhado por crescentes setores do Partido Liberal, que acusavam o Imperador de pautar a reforma e deixar pouco espaço para a atuação de ministros e parlamentares.

O fracasso da política do ministério, patrocinada pelo monarca, foi coroado com a derrota do projeto de reforma eleitoral no Senado. Após ficar claro que o clima político se tornara tenso, e que a probabilidade de algum sucesso na queda de braço com o Parlamento era remota, o Imperador parece ter reconhecido a inviabilidade da permanência de Sinimbu à frente do governo, e passou, ele mesmo, a criar crescentes empecilhos ao gabinete. Ora defendendo a participação do Senado na reforma, ora expondo sua oposição ao censo baixo e propondo que fosse "ajustável pela inflação", para contrabalançar a suposta falta de educação política do povo, ora advogando a exclusão dos não católicos, o monarca criava dificuldades crescentes ao avanço da reforma que ele mesmo havia "imposto a Sinimbu". ${ }^{140}$ Se, conforme observação do liberal baiano João Ferreira de Moura, d. Pedro II não escondia que só aceitava a eleição direta por não poder escapar de suas atribuições como monarca constitucional, também se mostrava pouco disposto em permitir que avançasse sem sua supervisão minuciosa. Em carta a Saraiva, Moura explicitou seu desgosto com o procedimento do chefe de Estado. ${ }^{141}$ Segundo ele, o monarca chamara Sinimbu ao poder, formulara a reforma e, depois desta ser liquidada no Senado, se dizia temeroso em conceder a dissolução da Câmara dos Deputados, o que, denunciou o deputado baiano, jamais tivera pudor em fazer. ${ }^{142}$

Moura, que era ministro da Marinha, pouco antes já relatara as contantes quedas de braço que marcaram os momentos finais do gabinete chefiado pelo senador alagoano. ${ }^{143}$ Segundo o político baiano, após a derrota do projeto Sinimbu no Senado, o monarca, ao mesmo tempo em que se mostrava pouco disposto a conceder a dissolução da Câmara ao

138 Cf. Barão de Javari, op. cit., pp. 177-179.

139 A expressão é de Pedro Leão Veloso, senador baiano, em carta a Saraiva, datada de 14/02/1878, AIHGB, L. 273, P. 39, apud Guo-Ping Mao, op. cit., p. 150, nota 3.

140 João Ferreira de Moura a José Antônio Saraiva, Rio de Janeiro, 13/03/1880. AIHGB, L. 274. P. 31. Apud Guo-Ping Mao, op. cit., p. 163, nota 22.

141 Ibid., p. 163, nota 22.

142 Ibid., p. 163, nota 22.

143 João Ferreira de Moura a José Antônio Saraiva, 29/02/1880. AIHGB. L. 274 P. 31. Apud Roderick J. Barman, Imperador cidadão, p. 416. 
gabinete, sondava a possibilidade de nomear um novo ministério, chefiado por Saraiva, e que fosse capaz de passar, sem alterações, o projeto no ramo vitalício do Poder Legislativo, evitando dissolver a câmara temporária. Ciente da habilidade e prestígio político do senador baiano, não era estranho que Pedro II cogitasse que, sob sua liderança, se alcançaria a aprovação do projeto. Mas, paradoxalmente, era essa mesma estatura política que inabilitava Saraiva para a tarefa. Não foram poucos, nesse sentido, os políticos liberais que alertaram o monarca quanto à esterilidade de suas sondagens, já que o senador baiano possuía "ideias próprias" sobre o teor da reforma eleitoral. ${ }^{144}$ Deste modo, o Imperador se viu numa posição cada vez menos confortável, encurralado pela pressão de um número crescente de liberais para que o partido assumisse uma "política de determinação". ${ }^{145}$ Diante de tal quadro, as opções do chefe de Estado eram escassas, pois, segundo o então ministro da Marinha,

[v]oltar-se aos conservadores significaria a vitória do Senado, um órgão com filiação vitalícia e sem nenhuma confiabilidade. A luta está sendo travada entre o poder do Senado e os atributos do poder regulador, que foi, como todos sabem, o autor do presente projeto, e que publicamente declarou na carta a Caxias que derrubou os conservadores para que a reforma fosse feita pelos liberais. ${ }^{146}$

Nesse sentido, a derrota de Sinimbu e a ascensão de Saraiva com um projeto próprio de eleição direta por vias parlamentares ordinárias se afigura uma importante derrota do monarca, que, quando em confronto com o Parlamento, precisava negociar cuidadosamente para avançar suas prioridades. No limite, o que tais acontecimentos demonstram é que a vontade imperial só prevalecia quando o Poder Legislativo permitia que assim o fosse.

A mudança do gabinete pode ser interpretada, destarte, à luz da intervenção do "poder irresponsável" na condução da reforma eleitoral, indesejada para a grande maioria dos políticos de ambos os partidos constitucionais. Era a superação de uma "política de submissão", que praticava Sinimbu, por uma "política de determinação", desejada por Silveira Martins e outros eminentes correligionários seus, que devolveria ao Parlamento total controle sobre a condução da reforma. Manuel Pinto de Souza Dantas, nomeado

144 Ibid.

145 Leão Veloso a Saraiva, Rio de Janeiro, 14/02/1878, AIHGB, L. 273. P. 39. Apud Guo-Ping Mao, op. cit., p. 150 , nota 3 .

146 João Ferreira de Moura a José Antônio Saraiva, 29/02/1880. AIHGB. L. 274 P. 31. Apud Roderick J. Barman, op. cit., p. 416. 
ministro da Justiça quando da chegada de Saraiva à presidência do Conselho, resumiu bem a questão: com a nomeação de seu aliado e comprovinciano à chefia do novo gabinete, com amplos poderes para prescindir da reforma constitucional, “[o] sistema representativo no Brasil ganhou imensamente". ${ }^{147}$

Por outro lado, é importante ressaltar que o fato de parlamentares de ambos os partidos terem se unido contra a intervenção do monarca não significava que suas expectativas quanto à reforma eleitoral e à implantação da eleição direta fossem semelhantes. Parece ter sido exatamente a inocuidade do projeto de Sinimbu que, adotando uma reforma extremamente limitada e pretensamente apartidária, o indispôs com seus correligionários. Como indicam as afirmações de Silveira da Mota e José Bonifácio, bem como a negativa de Saraiva, eles desejavam muito mais do que lhes era oferecido. A ascensão do prestigioso senador baiano à presidência do Conselho foi também uma resposta a tais aspirações.

\section{3 - Partidos e eleições: a Lei Saraiva}

A mudança do clima político engendrada pela transição ministerial se mostrou notável. Ela foi atestada por um dos maiores críticos do gabinete Sinimbu. Em abril de 1880, Joaquim Nabuco se levantou após a apresentação de Saraiva à Câmara dos Deputados, como novo presidente do Conselho, para declarar seu apoio ao gabinete. Unido anteriormente a José Bonifácio na oposição à "Constituinte constituída", o liberal abolicionista enxergava com bons olhos as perspectivas para a reforma eleitoral:

É por isto, senhores, que sem dissolução da Câmara, sem procurar aprofundar no partido liberal divergências passageiras, sem haver proscritos nem proscritores, podendo-se marcar um prazo curto dentro do qual as divergências passadas terão de ser desvanecidas, ficando apenas gravada na lembrança dos que as suscitaram; certo de que o direito de voto não será mais restringido, mas garantido a todos que dele estavam de posse, o ministério atual operou uma transformação tão completa na situação política do país como se ele assistisse à ascensão de outro partido, de outros homens, de outra situação.

$[\ldots]$

Se lutamos, foi para que vingassem as ideias do partido liberal, foi para livrar o partido liberal da pressão sob a qual se achava, foi para restituir-lhe toda a liberdade de ação. ${ }^{148}$

147 Manuel Pinto de Souza Dantas a José Antônio Saraiva, 07/03/1880. AIHGB. Col. Saraiva, DL 272.39, doc. 1 .

148 ACD. 22/04/1880, p. 17. 
Além da derrota do monarca e da "liberdade de ação" que sua ascensão à presidência do Conselho garantia ao Partido Liberal, louvadas por Nabuco, o projeto que Saraiva apresentou, a partir de suas "ideias próprias", bastante distinto da reforma pretendida por seu antecessor, também receberia o apoio do abolicionista pernambucano. Cabe, neste momento, expor alguns de seus pontos-chave. ${ }^{149}$

$\mathrm{O}$ artigo $1^{\mathrm{o}}$ da proposta determinava que a nomeação de todos os ocupantes de cargos eletivos, a nível nacional, provincial ou local, seria realizada por meio de eleições diretas, das quais participariam "todos os cidadãos considerados eleitores em virtude desta lei". A definição de quais cidadãos estariam aptos a exercer tal direito se encontrava no artigo seguinte. Interessa reproduzi-lo integralmente:

\section{Art. $2^{\circ}$}

É eleitor todo o cidadão brasileiro, nato ou naturalizado, católico ou acatólico, ingênuo ou liberto, compreendido nos $\S \S 1^{\circ}, 2^{\circ}, 3^{\circ}, 4^{\circ}$ e $5^{\circ}$ do art. 6 da Constituição do Império, ${ }^{150}$ estando no gozo de seus direitos políticos, dadas as seguintes condições:

$\S 1^{\circ}$ Ser maior de 21 anos com exercício dos direitos civis;

$\$ 2^{\circ}$ Perceber por bens imóveis, comércio, indústria, emprego, títulos de dívida pública, ações de bancos e companhias legalmente autorizadas, renda anual não inferior a $200 \$$; ou achar-se compreendido nos $\S \S 1^{\circ}, 2^{\circ}, 3^{\circ}$ e $4^{\circ}$ do art. 4 desta lei..$^{151}$

Parecem referir-se a este artigo $2^{\circ}$ algumas das palavras de Joaquim Nabuco acima reproduzidas, com sua certeza de que o ministério que então passava a se encarregar do exercício do Poder Executivo não restringiria o direito ao voto, mas o garantiria a "todos que dele estavam de posse". Se, como vimos, a reforma da Constituição pretendida pelo

149 O projeto encontra-se em: ACD. 29/04/1880, pp. 29-34.

$150 \mathrm{O}$ art. 6 da Constituição do Império dispunha sobre quem eram os cidadãos brasileiros. Os parágrafos citados determinavam: $1^{\circ}$ Os que no Brasil tiverem nascido, quer sejam ingênuos, ou libertos, ainda que o pai seja estrangeiro, uma vez que este não resida por serviço de sua Nação; $2^{\circ}$ Os filhos de pai Brasileiro, e os ilegítimos de mãe Brasileira, nascidos em país estrangeiro, que vierem estabelecer domić́lio no Império; $3^{\circ}$ Os filhos de pai Brasileiro, que estivesse em país estrangeiro em serviço do Império, embora eles não venham estabelecer domicílio no Brasil; $4^{\circ}$ Todos os nascidos em Portugal, e suas possessões, que sendo já residentes no Brasil na época em que se proclamou a Independência nas Províncias onde habitavam, aderiram a esta expressa, ou tacitamente pela continuação da sua residência; $5^{\circ}$ Os estrangeiros naturalizados, qualquer que seja a sua religião. A Lei determinará as qualidades precisas, para se obter Carta de naturalização. Cf. Adriano Campanhole e Hilton Lobo Campanhole, op. cit.

1510 artigo $4^{\circ}$ do projeto dispunha sobre os cidadãos "considerados como tendo a renda legal", independentemente das provas exigidas para a qualificação eleitoral. Entre eles estavam os diplomados em faculdades, academias ou institutos, os clérigos de ordens sacras, os que exerciam magistério público ou particular, além de capitães de navios mercantes ou pilotos. A questão da qualificação dos eleitores será abordada mais adiante. ACD. 29/04/1880, p. 30. 
ministério Sinimbu adotava o censo e as restrições até então existentes à participação como eleitor, o projeto Saraiva tinha na adoção do censo do votante, com a inclusão de todos que, constitucionalmente, gozavam de direitos políticos, um ponto essencial.

Outra diferença importante entre os projetos estava na questão da elegibilidade. Enquanto a proposta de reforma constitucional não mencionava o artigo 95 da Constituição, que dispunha sobre os cidadãos elegíveis e excluía de tal direito os votantes, além de exigir renda alta para aqueles que desejassem se candidatar a cargos no Legislativo geral, o projeto Saraiva dedicava seis artigos a tal questão. No primeiro de tais artigos, percebe-se a sensível diferença entre o espírito dos dois projetos:

Art. $8^{\circ}$

É elegível para os cargos de senador, deputado geral, membro da assembleia legislativa provincial, vereador, juiz de paz e quaisquer outros criados por lei todo o cidadão compreendido no art. $2^{\circ}$, salvas as restrições adiante enumeradas:

$\S 1^{\circ}$ É condição especial de elegibilidade:

Para senador do Império - ser maior de 40 anos;

Para deputado geral ou membro da assembleia provincial - ser maior de vinte e cinco anos, salvo se o eleito tiver algum grau científico;

Para vereador e juiz de paz, a de residência durante dois anos pelo menos dentro do município. ${ }^{152}$

Todos os cidadãos do Império, independentemente de sua pregressa condição jurídica e desde que nascidos ou naturalizados brasileiros, teriam, virtualmente, o direito de votar e ser votados, se cumprissem certos requisitos. Libertos, ingênuos, não católicos, estrangeiros naturalizados que atingissem a renda de 200 mil réis, considerada então pouco significativa, ${ }^{153}$ estariam aptos a exercer seus direitos políticos integralmente.

As disposições igualitárias do projeto não deixaram de ser notadas por antigos opositores do ministério Sinimbu. Joaquim Nabuco, como vimos, emprestou rapidamente seu apoio ao novo gabinete, afirmando que acompanharia, "como soldado, ao nobre presidente do conselho [Saraiva]", quando seu projeto suprimisse todas as diferenças existentes entre os cidadãos brasileiros, quando previsse uma realidade em que "os libertos que não podiam ser eleitos pela Constituição, possam ser deputados, sentar-se no Parlamento brasileiro" ao lado de seus ex-senhores, quando, ainda, concedesse todos os

152 ACD. 29/04/1880, p. 31.

153 Segundo Mircea Buescu, a quantia de 200 mil-réis era bastante reduzida para a época, não sendo incomum que trabalhadores humildes, como carpinteiros e operários da alfândega, tivessem renda consideravelmente superior. Cf. Mircea Buescu, "No centenário da Lei Saraiva", Revista do IHGB, Rio de Janeiro, n 330 , jan/mar de 1981, p. 239. 
direitos políticos a estrangeiros que estivessem dispostos a tornar-se cidadãos brasileiros e previsse o fim de todas as diferenças religiosas. ${ }^{154}$ Joaquim Saldanha Marinho, feroz crítico do projeto Sinimbu, por sua vez, se mostrou menos resistente à proposta que o novo líder do governo desejava avançar no Parlamento. Oferecendo sua opinião sobre o projeto, destacou Saldanha Marinho:

Cumpre-me, porém, dizer, e com satisfação o faço, que o projeto, em sua perspectiva e nas grandes aspirações liberais que encerra, é em minha humilde opinião, magnífico, é da pura escola democrática (Apoiados)

$[\ldots]$

O projeto nos oferece: eleição direta, distritos de um só deputado, admissão dos acatólicos, dos ingênuos e libertos e dos naturalizados à elegibilidade. ${ }^{155}$

Por outro lado, Saldanha Marinho não poupava o projeto de críticas quando o que estava em jogo era a objetividade de suas disposições igualitárias. A garantia virtual de direitos, se louvável, observava o deputado pelo Amazonas, não parecia capaz de se materializar num futuro previsível. A razão de tal disparidade estava ligada, essencialmente, ao processo de qualificação dos eleitores. Deste modo, no discurso citado, Saldanha Marinho expressou sua contrariedade com o que chamou de "espoliação" em referência à dificuldade de comprovação da renda exigida. Se, pelo censo baixo e pelo caráter igualitário, a letra do projeto fazia supor que todos os então votantes se tornariam eleitores no novo sistema, tal princípio poderia ser iludido, comprometendo "a grande ideia do governo do povo pelo povo", se a prova de renda somente pudesse ser realizada pelo "conhecimento de pagamento do imposto, certidões de tribunais, e do notariado, títulos de propriedade e de arrendamento lançados em notas do tabelião do distrito", pois esse tipo de documentação específica não era comum entre a população, especialmente nas camadas mais humildes, em que se incluíam os "operários" e "trabalhadores rurais", muitos dos quais possuíam renda que ultrapassava a exigida para tornarem-se eleitores, mas não teriam como comprová-la.

As contradições inerentes a tais disposições não escaparam à comissão de legislação da

154 ACD. 22/04/1880, p. 19.

155 ACD. 01/06/1880, p. 326 (grifos no original). Mais adiante, Saldanha Marinho reforça tais impressões quanto ao caráter avançado do projeto: "Sr. Presidente, a admissão dos ingênuos e dos libertos, a elegibilidade e a faculdade que se lhes concede de poderem também representar o país em que nasceram, é uma das ideias de mais moralidade e perfeita justiça que o projeto contém". Seria por essa via de ampliação dos direitos políticos dos cidadãos, independentemente de sua origem social, que "o Brasil fará esquecer de uma vez para sempre a escravidão, que ainda amesquinha sua civilização. O nascimento escravo não será um motivo de interdição civil ou política contra ninguém”. Ibid., p. 329. 
Câmara, cujo parecer explicitou as dificuldades que surgiriam das detalhadas exigências previstas na prova de renda. Porém, pareceram, à maior parte dos deputados da referida comissão, inevitáveis. ${ }^{156}$ Afirmavam no parecer, a que Saldanha Marinho emprestou seu voto "com restrições":

Sobressai entre os pensamentos e ideias cardeais da proposta não deixar arbítrio algum às juntas e juízes encarregados do alistamento eleitoral, que ficam adstritos a julgar provas documentais. Este rigor, em matéria de provas, quis a proposta compensar por algum abaixamento do censo, de sorte que o direito eleitoral tocasse o maior número de cidadãos.

A comissão reconhece que há dificuldade de provas documentais para o censo, que aproveitem a todos quanto devem ter o direito eleitoral, quando ainda não temos um sistema de imposições diretas, nem é lícito pensar, sequer, em criar novas imposições quaisquer, sem aliviar a população do gravame enorme de impostos de que está sobrecarregada.

Assim, a comissão, aceitando estes artigos da proposta, aguarda os conselhos que a prática e a execução da lei nos darão, para ampliarmos progressivamente o sufrágio, sem expor o processo eleitoral e as qualificações notavelmente aos muitos abusos que o arbítrio e a fraude tinham produzido neles. ${ }^{157}$

$\mathrm{Na}$ ausência de impostos vinculados diretamente à renda dos cidadãos, fazia-se necessária considerável rigidez na comprovação de renda. A grande razão por trás de tal severidade estava, segundo o discurso dos defensores do projeto, na necessidade de se coibir a intervenção das juntas de qualificação nas eleições, percebidas por muitos como as principais responsáveis pelo falseamento dos pleitos. Foi nesses termos que, em longa resposta endereçada aos críticos do projeto, Saraiva defendeu as severas medidas previstas. $^{158}$

O presidente do Conselho iniciou seu discurso definindo com clareza o que considerava ser o espírito do projeto e as expectativas que nutria o Partido Liberal com relação a ele. Segundo Saraiva, era evidente que o projeto não queria "decidida e absolutamente o voto universal", assim como não o desejava o partido. O que o projeto cumpria, observou o chefe do governo, era a "aspiração maior dos liberais chamados ultra", isto é, “fazer do votante da Constituição o eleitor". Deste modo, aqueles, como Saldanha Marinho, que atacavam a severidade da prova de renda seriam levados "forçosa e

156 Dezenove deputados fizeram parte da Comissão que alterou pontualmente o projeto, não causando transformações significativas no espírito de suas disposições. Entre seus membros, estavam Martinho Campos, Martim Francisco Ribeiro de Andrada, Rui Barbosa, Joaquim Nabuco e o próprio Saldanha Marinho. ACD. 25/05/1880, pp. 233-241.

157 Ibid., p. 234

158 ACD. 04/06/1880, pp. 33-44. 
invencivelmente ao voto universal", o que, naquele momento, estava fora do programa e das aspirações do Partido Liberal. Dentro de tal lógica, para Saraiva, era inevitável que qualquer projeto excluísse alguém, mesmo que, por natureza, fosse inclusivo. E para o presidente do Conselho, diante de uma prova de renda deficiente, seria preferível o voto universal ao voto censitário, deixando àqueles que criticavam as rígidas disposições do projeto a responsabilidade de virem a público defender a absoluta generalização do sufrágio. ${ }^{159}$ Às reclamações de que os "operários" seriam as principais vítimas do rigor do projeto, Saraiva replicou terem pouca relação com a realidade sensível do país, onde todos os homens que se sentavam no Parlamento seriam "netos ou bisnetos de operários":

O que faz o projeto? Ataca os direitos do operário? Não; o projeto consigna o desenvolvimento do $\S 14$ do art. 179 da Constituição, o qual todo o liberal deve ter em vista quando faz um projeto, e que é o seguinte (lendo):

'Todo o [sic] cidadão pode ser admitido aos cargos públicos, civis, políticos ou militares sem outra diferença que não seja a de seus talentos e virtudes'.

De maneira que, desde que um projeto estabelece a condição de igualdade para todos, não se pode dizer que aqueles que não estão nessa condição sejam excluídos. Não se exclui ninguém; apenas o projeto pede que pelo trabalho, pela economia, por tudo quanto há de mais justo e de mais honesto, o indivíduo se habilite a ter o direito de ser eleitor de seu país (Apoiados; muito bem). É uma animação ao trabalho, Sr. presidente. ${ }^{160}$

Para Saraiva, caminhar gradualmente pela senda da expansão do sufrágio aliava a garantia das liberdades fundamentais à segurança do Estado sem comprometer a igualdade formal e, mais importante, sem deixar de levar em consideração que as desigualdades naturais dos indivíduos não podiam ser ignoradas em uma sociedade que se pretendia liberal. Deste modo, o presidente do Conselho tomava o exemplo da pátria do liberalismo para reforçar suas colocações:

Há muitos anos ou séculos que diversos países do mundo, que se reputam e querem ser livres, simpatizam mais com a igualdade do que com a liberdade; alguns, para atingirem o máximo da igualdade, deixam de lado a liberdade, e outros, visando antes a liberdade, respeitam o grande princípio da natureza, a desigualdade do talento e das virtudes, que não se pode negar, porque é impossível fazer um homem igual a outro (Apoiados).

Pois bem, acerca destes dois princípios qual é o país que tem obtido mais resultados?

A Inglaterra, onde não há igualdade no eleitorado. E como é que a Inglaterra tem chegado a exigir uma renda menor do que a que tinha há anos? Indo, senhores, pouco

159 Ibid., pp. 34-35

160 Ibid., p. 35. 
e pouco aumentando a base do eleitorado, à proporção que o país se civiliza e que as classes ilustradas vão preponderando mais na administração do Estado.

No Brasil, principiamos fazendo do votante um eleitor, e entretanto o projeto é atacado. O que deixais ao futuro? ${ }^{161}$

Ao fazer tais observações, Saraiva também mirava as investidas contra a criticada exigência de alfabetização dos eleitores, decorrente do fato de que se demandava que os títulos eleitorais fossem assinados para terem validade. ${ }^{162}$ Para o presidente do Conselho, tal questão estava ligada à lisura do processo de qualificação eleitoral e à estabilidade do eleitorado, fundamentais para o bom funcionamento de todo o sistema. A necessidade de apresentação de provas contundentes, inclusive documentos assinados pelos cidadãos, provinha de um duplo objetivo que se impunha em conjunto com a eleição direta: a redução de irregularidades era, segundo sugere o presidente do Conselho, tributária da qualificação permanente dos eleitores, com a possibilidade de comprovarem facilmente sua identidade. ${ }^{163}$ Observava Saraiva que o projeto - ao seguir as disposições da lei de 1875 , de que, uma vez qualificado, o eleitor só perderia o direito ao voto em caso de falecimento ou de mudança de domicílio, situação em que precisaria realizar nova matrícula - oferecia garantias inquestionáveis à liberdade dos pleitos. Diante de tal estabilidade do corpo de eleitores e da exigência de provas inquestionáveis da capacidade eleitoral de cada indivíduo, o papel das juntas deixaria de ser ativo no processo de qualificação, restringindo significativamente a influência do partido da situação nas eleições. O mais ilustre crítico do ministério Sinimbu, José Bonifácio, recém-empossado na câmara vitalícia, ecoou tais vantagens das eleições diretas no o combate à "falta de liberdade" que corroía o sistema político do país:

Na história tristíssima da sua vida [da eleição indireta] cinco abundantíssimas fontes de vícios, fraudes e abusos ela oferece aos olhos do observador desapaixonado: a infidelidade das qualificações, a soberania das mesas eleitorais, a fraqueza dos votantes, a dependência do eleitor e a intervenção do governo.

161 Ibid., p. 36. Adiante, Saraiva observa sobre as previsíveis restrições à participação eleitoral: "Mas, senhores, se assim é, por que não havemos de ser prudentes?" E, destarte, "por que não havemos de dizer aos nossos concidadãos que ficam à porta, e que não podem entrar por este projeto, que esperem um, dois, ou mais anos para entrar?".

162 ACD. 29/04/1880, p. 31.

163 Contudo, os cidadãos analfabetos já reconhecidos em alistamentos anteriores mantiveram o direito ao voto, desde que tivessem meios de apresentar a comprovação de renda exigida pelo projeto. Os eleitores que não pudessem assinar seus títulos eleitorais poderiam indicar outro eleitor que por eles assinasse. Cf. Francisco Belisário Soares de Souza, op. cit., p. 343. Isto indica que, para seus autores, a restrição do voto aos cidadãos não alfabetizados que já dispunham de tal direito seria inconstitucional. 
Sem dúvida estes vícios não desaparecerão de todo com a eleição direta, mas tenderão a diminuir cada vez mais. A infidelidade das qualificações tem a sua origem na ausência de dados estatísticos, na manobra fraudulenta dos partidos, no interesse imediato do governo, na deficiência e confusão da prova. [...] Com a eleição direta, a qualificação é permanente, a prova deve conter em si mesma a certeza da verdade, as juntas ou conselhos tornam-se passivos, reconhecendo apenas os títulos da qualificação, o magistrado é, como garantia última, o simples observador do preceito legal, afirmando a existência da prova indicada pelo legislador". ${ }^{164}$

Além da restrição do papel das juntas, a atuação das mesas eleitorais seria também reduzida, já que, de acordo com o projeto, no dia do pleito os eleitores apresentariam seus títulos eleitorais assinados, provando peremptoriamente sua identidade e coibindo equívocos e favorecimentos ilícitos.

O projeto previa, em seu artigo $5^{\circ}$, que o processo de alistamento adotado pela Lei do Terço "vigorará para o primeiro alistamento dos eleitores na execução desta lei, em tudo que não for expressamente revogado ou contrário às suas disposições". ${ }^{165}$ No entanto, fazia uma alteração significativa. Como vimos, a lei de 1875 previa que as juntas municipais, ultimamente responsáveis pela avalização do trabalho apenas preliminar das juntas de qualificação, ${ }^{166}$ seriam compostas por um substituto do juiz de direito ou pelo juiz municipal no município em que residisse, ao lado de mais "dois membros eleitos pelos Vereadores da Câmara". ${ }^{167}$ Cabiam, ainda, ao juiz de direito e à Relação do Distrito, recursos em caso de irregularidades ou exclusões contestadas. ${ }^{168}$ Se o projeto apresentado por Saraiva mantinha as juntas de qualificação idênticas às criadas pela Lei do Terço, previa uma alteração importante na composição das juntas municipais. Sem fazer menção a "substituto do juiz de direito", dispunha que estariam ao lado do juiz municipal o "vereador mais votado" e o "primeiro juiz de paz do distrito da matriz", duas autoridades localmente eleitas, portanto. ${ }^{169}$ Além disso, não se previa papel proeminente ao juiz de direito, que teria como função "apenas receber as cópias do alistamento, depois de examinar a sua autenticidade e rubricá-las folha por folha”, remetendo-as ao presidente da câmara municipal e ao tabelião. ${ }^{170}$ Ao atribuir o cerne da responsabilidade sobre ao

164 AS. 22/10/1880, p. 246.

165 ACD. 25/05/1880, p. 237.

$166 \mathrm{Na}$ Lei do Terço, as juntas de qualificação eram eleitas, em pleitos presididos pelos juízes de paz, por eleitores de paróquia. Cf. Francisco Belisário Soares de Souza, op. cit., p. 248.

167 Ibid., p. 249.

168 Ibid., p. 254.

169 ACD. 25/05/1880, p. 237.

170 Isto porque "haveria dois registros dos eleitores: um na câmara municipal e outro no cartório de um tabelião designado, na corte pelo ministro do Império e nas províncias pelos presidentes". Ibid., p. 237. 
alistamento eleitoral a autoridades locais eletivas, o projeto Saraiva estava, portanto, mais próximo às disposições das leis de 1846 e 1855 do que da lei eleitoral aprovada sob o ministério Caxias.

Outro ponto que o vinculava à "pura escola democrática", segundo as palavras de Saldanha Marinho, ${ }^{171}$ era o retorno dos distritos uninominais, instaurados pela lei de 1855 , expandidos em 1860 e abandonados em 1875. O presidente do Conselho que, 20 anos antes, fora, na condição de deputado pela Bahia, um dos principais defensores da ampliação dos distritos, era então acusado de incoerência, por defender um projeto que previa a adoção de distritos uninominais. Em sua defesa, Saraiva destacou a sensível diferença existente entre voto em distritos reduzidos sob um sistema eleitoral indireto e o mesmo modelo sob um sistema com eleições diretas. Segundo o presidente do Conselho, se antes não eram recomendáveis os distritos restritos devido à grande possibilidade de formação de "oligarquias", com a adoção de eleições diretas eles teriam um efeito oposto:

[...] convertei o sistema indireto no sistema direto por círculos, que, em vez de terem 30 ou 40 eleitores, tenham 1.000, 2.000 e 3.000, e tudo estará mudado, não haverá mais influência oligárquica, o povo votará livremente. (Muito bem $)^{172}$

Justiça seja feita ao presidente do Conselho, ele havia mantido sua coerência ao longo daquelas duas décadas. Em 1860, fora exatamente nesses termos que defendera a ampliação dos círculos ou distritos eleitorais:

Dar a um pequeno número de eleitores o direito de fazer um deputado é excitar os interesses individuais, é dar ganho de causa aos interesses pessoais, locais, sobre os interesses públicos, sobre os interesses nacionais. [...] Círculo de um deputado em regime de eleição indireta é a representação mais brilhante do princípio oligárquico em todos os pontos do Império. ${ }^{173}$

Àqueles que afirmavam que seu projeto de eleição direta produziria um número reduzido de eleitores, Saraiva lembrava que a ampliação em cerca de dez vezes do eleitorado, ${ }^{174}$ realizando-se sua qualificação permanente, significaria uma inflexão considerável no panorama da política imperial, instaurando a liberdade eleitoral contra "o

171 ACD. $01 / 06 / 1880$, p. 326

172 ACD. 04/06/1880, p. 37.

173 ACD. 19/06/1860. Apud Miriam Dolhnikoff, "Representação na monarquia brasileira”, p. 52.

174 Segundo as estimativas da época, o Império contava com menos de 24 mil eleitores antes da aprovação da Lei Saraiva. AS. 22/10/1880, p. 249. 
poder pessoal mais desmoralizador que tem havido em todo o Brasil; o poder dos chefes de partido". ${ }^{175}$ As eleições diretas em distritos uninominais possibilitariam, então, que a Câmara dos Deputados fosse representativa dos interesses locais e provinciais de forma mais genuína, sem que houvesse submissão aos potentados locais nem aos chefes partidários das províncias.

Ao apresentar um projeto que continha muitas das bandeiras históricas do Partido Liberal, Saraiva pretendia restituir a "liberdade de ação" a seus correligionários, como já afirmara Nabuco. ${ }^{176}$ Contudo, nenhum de seus aliados ignorava o fato de que a aprovação do projeto no Senado, dominado por uma maioria do partido adversário, dependeria de intensa negociação com os conservadores, ao menos com aqueles que aceitavam a eleição direta. ${ }^{177}$ Foi realmente o que ocorreu, e, em sua passagem pela câmara vitalícia, o projeto foi significativamente alterado.

Já antes de apresentá-lo à Câmara, o presidente do Conselho demonstrara estar mais do que ciente de que só por meio de um compromisso que envolvesse ambos os partidos poderia a reforma ser bem-sucedida. Numa amostra de seu desejo de angariar o apoio, ou ao menos a cooperação, de seus adversários, Saraiva enviou a algumas lideranças conservadoras o projeto de reforma eleitoral, antes de apresentá-lo ao Parlamento, para que fizessem considerações e sugerissem alterações. Deste modo, o chefe de gabinete teria mais clareza sobre os termos do debate que o aguardava. Entre os consultados por Saraiva, estiveram Paulino de Souza, líder máximo do Partido Conservador fluminense, e Antônio Ferreira Viana, um dos seus mais destacados membros. A começar pela questão dos direitos políticos, o conflito de opiniões era flagrante.

Declarando-se grato ao presidente do Conselho por sua cortesia em permitir que expusesse sua opinião, Paulino expressou sua visão sobre uma das prioridades da reforma:

Não sou dos que sacrificam as esperanças da liberdade política séria e prática,

175 ACD. 04/06/1880, p. 37.

176 ACD. 22/04/1880, p. 17.

177 Nesse sentido, declarou Joaquim Nabuco: "A lei que nós votarmos será uma lei liberal; mas como nos voltará ela do Senado? Voltará emendada, de certo, se triunfar a reforma por lei ordinária; mas essas emendas tornarão a lei conservadora, por forma que nós neste recinto não the possamos dar o nosso apoio?" Se a preponderância do barão de Cotegipe no Partido Conservador se fizesse sentir, observou Nabuco, era improvável que voltasse à Câmara uma lei "a que como liberais não possamos dar nosso voto". Contando "com o censo da Constituição para o votante, com a igualdade política de todos os brasileiros, sem distinção de religiões, de castas, de origens, é uma reforma liberal, e para realizá-la o nobre presidente do Conselho pode contar com todo o nosso apoio", arrematou o deputado pernambucano. Ibid., p. 19. 
prometida pela Constituição, às ilusões de um vão espírito democrático. E como a experiência atesta que a aplicação tem traído a aspiração popular da universalidade do voto, sou francamente adeso [sic] ao princípio doutrinário da capacidade. Partindo daí e tendo opinado contra a necessidade de reforma da Constituição, vejo que a decretação da Eleição direta por lei ordinária obriga a adotar o censo constitucional do eleitor e portanto a meu ver deve ser eleitor direto todo aquele que pode ser hoje eleitor indireto, omisso medio, isto é, dispensada a intervenção dos votantes para restringir-lhes o número pela designação nas assembleias paroquiais. ${ }^{178}$

Como seu primo, Francisco Belisário, Paulino desejava uma lei restritiva, que excluísse os votantes da participação eleitoral, deixando aos mais "capazes" a exclusividade de intervir nos negócios públicos. Deste modo, o conservador fluminense remetia à lei fundamental do Império para defender a adoção do "censo constitucional do eleitor”, o que, em suas palavras, significava não apenas a exigência de renda mais alta, como a exclusão de libertos na eleição direta. Nesse sentido, a elevação do censo, advertiu Paulino, era "a principal condição do êxito da reforma"; ignorando-a, o "sacrifício" que fazia Saraiva seria "mais uma decepção e improfícuo". ${ }^{179}$ Percebe-se aqui uma clivagem significativa na interpretação da Constituição. Para os liberais, uma lei ordinária não poderia retirar direitos políticos previstos na carta fundamental, e desde então exercidos por tal ou qual parcela da população, no caso os votantes. Paulino, em contrapartida, apresentava uma interpretação peculiar do diploma de 1824, interpretação essa que permitia equivaler o eleitor da eleição direta àquele Eleitor constitucional de $2^{\circ}$ grau. No mesmo sentido, o conservador fluminense desaprovou as amplas disposições sobre os elegíveis, recomendando que fossem excluídas do projeto, pois “[a]s condições para ser deputado, referindo-se à capacidade legal para o exercício do poder político, envolvem matéria essencialmente constitucional e fora da órbita de uma lei regulamentar". ${ }^{180}$

Ferreira Viana foi ainda mais longe em suas considerações. ${ }^{181}$ Após expressar, em longo preâmbulo, apoio à causa da eleição direta, como meio de devolver ao país o poder de si mesmo, e admiração por Saraiva, pela bravura em enfrentar o "poder irresponsável”, o político conservador iniciou suas recomendações. Se fosse deputado e tivesse voto, asseverou, "requereria a V. Ex. [Saraiva] de separar do projeto algumas disposições": a elegibilidade dos acatólicos, dos estrangeiros naturalizados e dos libertos the pareciam depender do poder constituinte, "além de outras razões que não cabem nesta resposta".

178 Paulino de Souza a José Antônio Saraiva. AIHGB. Col. Saraiva, Lata 277/Doc. 9, 09/04/1880.

179 Ibid.

180 Ibid.

181 Antônio Ferreira Viana a José Antônio Saraiva. AIHGB, DL 222.19, 17/04/1880. 
"Reduzida", destarte, "a reforma à mudança do sistema indireto pelo direto, a eleitores censitários e eleições por distritos, não seria difícil consegui-la das duas casas legislativas". Nesse ponto, Sinimbu, para ele, estava correto: “contentando-se com a mudança do processo eleitoral deixava ao país real a iniciativa de posteriores reformas". ${ }^{182}$ Menos correta era, no entanto, para o conservador fluminense, a simples exclusão dos analfabetos, pois o rigor nesse sentido deveria ser ainda mais abrangente. Recuperando a proposição drástica de Belisário, de que o voto seria "antes um dever social do que o gozo de um direito", ${ }^{183}$ Ferreira Viana indicava que não bastava exigir do eleitor certas aptidões, como saber ler e escrever, se este não tivesse real ciência dos negócios do país, se seus interesses privados não estivessem ligados aos interesses gerais da pátria. "Apesar das opiniões de Rousseau e Cícero", declarou o conservador, "não estou certo da conveniência do voto público no Brasil, dominado por tão exagerada centralização, fonte de dependências, esperanças e temores". ${ }^{184}$

Deste modo, Ferreira Viana sugeriu a criação de três níveis de eleitores distintos, baseada em suas posições como contribuintes e em sua independência e interesse na política. O meio para atingir tal fim seria reduzir "a prova do censo ao título de quitação de contribuição, taxa ou imposto", separando "o censo em três classes, dividindo assim os eleitores". Os eleitores gerais seriam aqueles que pudessem provar ter saldado "conhecimento", ou pagamento, de imposto, taxa ou contribuição geral, do mesmo modo que os eleitores provinciais, nas províncias, e municipais, a nível local. O eleitor, "[s]obre o dorso deste conhecimento", o comprovante de sua condição de contribuinte, escreveria "o nome do Senador, Deputado geral, provincial, vereador ou juiz de paz, e assinaria seu nome". "Apurada a eleição", realizada por tal processo, "os conhecimentos [declarações de contribuição] restituídos a seus donos perpetuariam os meios de verificação do processo eleitoral", criando assim um eleitorado permanente. Aquele cidadão que não estivesse "sujeito a imposto, contribuição ou taxa", mas desejasse tomar parte na eleição, em um dos três níveis, "poderia requerer ser incluído na lista dos contribuintes, e pago o tributo, taxa, ou contribuição ser contemplado na nominata dos eleitores". Tal contribuição "poderia ser estabelecida na lei e destinado seu produto à propagação do ensino e redenção dos cativos". ${ }^{185}$ Parecendo ciente da estranheza que poderiam causar suas propostas, Ferreira

182 Ibid. Grifo nosso.

183 Cf. Francisco Belisário Soares de Souza, op. cit., p. 116.

184 Ferreira Viana a Saraiva. AIHGB. DL 222.19, 17/04/1880. 185 Ibid. 
Viana continuou suas sugestões listando os "intuitos" que o levaram a formulá-las:

O primeiro intuito é preparar os elementos para a discriminação das rendas gerais, provinciais e municipais, e futura organização de um sistema equitativo de impostos.

O segundo, tornar impossível o uso dos supostos eleitores, estabelecendo como critério da capacidade eleitoral a contribuição para os serviços do Estado, da província e dos municípios.

O terceiro, graduar a taxa de imposto ou contribuição, de modo que o municipal seja mínimo, o provincial médio e o geral máximo. Assim pode-se dizer que ninguém seria excluído da função eleitoral ou na $1^{\mathrm{a}}$ ou na $2^{\mathrm{a}}$ ou na $3^{\mathrm{a}}$ classe.

Quarto. Fazer concorrer para a eleição apenas os interessados diretamente no bom governo geral, provincial ou municipal, ou por que sejam, ou se façam contribuintes $[\ldots]{ }^{186}$

Defendendo o censo constitucional do eleitor, limitação dos direitos políticos e a criação de categorias engessadas de cidadãos ativos, as expectativas dos conservadores fluminenses consultados iam de encontro ao previsto no projeto. Não foi, no entanto, apenas nesta questão que as divergências se mostraram significativas.

É o que se observa na posição crítica que Paulino de Souza adotou ao tratar do voto distrital uninominal. Para o importante chefe conservador, o retorno dos distritos de um só deputado representava riscos a todo o sistema representativo do Império:

Os distritos de um só deputado terão o inconveniente de desatar ainda mais o já tão frouxo laço dos nossos partidos políticos. Se um dos fins da reforma eleitoral é fortalecer os partidos substituindo o nexo político à cabala e intrigas dos corrilhos [sic], o resultado será contrário com os distritos irregulares, nos quais o deputado não tem outro meio de manter a sua influência senão a promoção dos interesses e pretensões dos seus parceiros da localidade.

O horizonte político estreita-se-lhe no círculo que tem por centro o campanário. Aos interesses da nação, da província, do partido antepõe-se o dos amigos do distrito, a que deve a eleição. É certo que as localidades podem imediatamente lucrar, mas baixa necessariamente o nível da representação nacional, amesquinhados os representantes pela pequenez de sua esfera política e pela postergação dos sentimentos generosos que desperta o espírito de coletividade.

$[\ldots]$

Em tantas legislaturas, nas quais fui deputado de 1857 a 1878 , a que vi animada de mais espírito político foi a de 1877, eleita por províncias, e a que vi mais movida por interesses pequeninos foi a de 1857, eleita por círculos, da qual V. Ex. se há de recordar, pois que nela como ministro dirigia a maioria. ${ }^{187}$

Paulino se utilizava de argumentos similares aos que seu grupo político, impiedosa

186 Ibid.

187 Paulino de Souza a Saraiva (particular), Val-de-Palmas, 09/04/1880. AIHGB. Col. Saraiva, L. 277 Doc. 9. 
oposição ao gabinete da Conciliação, recorrera 25 anos antes para desqualificar a reforma eleitoral pretendida por aquele gabinete, presidido pelo marquês de Paraná. ${ }^{188}$ Mais ainda, sugeria que a Lei do Terço, que tentara conciliar o voto provincial com a representação das minorias, poderia servir como modelo às eleições diretas, que lhe corrigiriam os "defeitos" mais salientes. Nesse mesmo sentido, Paulino reagiu negativamente ao processo de qualificação dos eleitores pretendido e à supressão das prerrogativas dos juízes de direito nas "inclusões e exclusões" de eleitores. ${ }^{189}$

O desacordo entre o presidente do Conselho e uma das mais destacadas lideranças da oposição conservadora demonstra, portanto, que, apesar do compromisso que ensaiavam na consecução da lei, havia expectativas profundamente distintas sobre o futuro do sistema eleitoral do Império, informadas por posicionamentos ideológicos e projetos políticos que datavam de muito tempo.

Saraiva parece ter solicitado os pareceres de lideranças conservadoras para sondar suas expectativas e conhecer de antemão os pontos em que se fixaria a oposição na câmara vitalícia, onde dominavam os adversários. Deste modo, o chefe do governo poderia traçar uma estratégia de negociação e definir, com seus aliados, os pontos em que poderia ceder e aqueles dos quais o governo faria questão. ${ }^{190}$

Se na Câmara dos Deputados, a imensa maioria aprovou o projeto sem relevantes alterações, ${ }^{191}$ o mesmo não se deu no Senado. Na Câmara alta, os representantes conservadores ecoaram as preocupações expressas por Paulino de Souza e Ferreira Viana. A dificuldade em passar o texto tal qual aprovado entre os deputados ficou evidente já no início da trajetória do projeto na câmara alta, onde passou, como era de praxe, pelo crivo de duas diferentes comissões da casa, ambas dominadas por políticos do Partido Conservador. Se a comissão de Legislação, composta por políticos conservadores opostos à eleição direta, se recusou a emendar o projeto, ${ }^{192}$ a Comissão de Constituição, formada

188 Cf. Paula Ribeiro Ferraz, op. cit., cap. 3 "Conciliação e reforma". Os antigos saquaremas foram ferozmente contrários à Lei dos Círculos.

189 Paulino de Souza a Saraiva (particular), Val-de-Palmas, 09/04/1880. AIHGB. Col. Saraiva, L. 277 Doc. 9.

190 Segundo Guo-Ping Mao, op. cit., Saraiva também enviou o projeto a políticos liberais que haviam feito parte do ministério Sinimbu, como Afonso Celso de Assis Figueiredo. Posteriormente, o presidente do Conselho declarou serem inegociáveis as disposições em torno da prova de renda e dos distritos uninominais. ACD. 06/04/1880.

191 Cf. Sérgio Eduardo Ferraz, op. cit., p. 178.

192 A comissão era formada por João Alfredo Correia de Oliveira, Cândido Mendes de Almeida e Joaquim Jerônimo Fernandes da Cunha, representantes de Pernambuco, Maranhão e Bahia, respectivamente. Seu voto em separado encontra-se em AS. 27/09/1880, pp. 427-8. 
por um triunvirato de destacadas figuras do partido - o barão de Cotegipe, o conde de Baependi e Fausto Augusto de Aguiar - ${ }^{193}$, emitiu um parecer acompanhado de projeto substitutivo. ${ }^{194}$ Reconhecendo a constitucionalidade da eleição direta, a comissão sugeriu alterações consideráveis nas disposições aprovadas pelos deputados.

No que dizia respeito aos direitos políticos, o parecer da segunda comissão citada apresentou restrições nada desprezíveis com relação ao texto aprovado pela Câmara dos Deputados. A primeira mudança já se encontrava no artigo $2^{\circ}$, em que a formulação original - que mencionava o direito ao voto de libertos, cidadãos naturalizados, independente da religião que professassem - foi reduzida, além de ter sido excluído o parágrafo que garantia direitos políticos aos maiores de 21 anos, mantendo a idade mínima constitucional para votar, 25 anos. ${ }^{195}$ No caso da primeira exclusão, o caráter das alterações era bastante simbólico, já que, lacônico, o novo texto, mantido na letra final da lei, declarava ser "eleitor todo cidadão brasileiro nos termos dos arts. $6^{\circ}, 91$ e 92 da Constituição do Império, que tiver renda líquida anual não inferior a $200 \$$ por bens de raiz, indústria, comércio ou emprego". ${ }^{196}$ Mantinha-se, portanto, o censo do votante, mas se evitava declará-lo explicitamente na lei.

A principal, entre tais restrições, no entanto, se ligava às disposições sobre os elegíveis, que foram suprimidas. Deste modo, enquanto o projeto emendado e votado pelos deputados previa que seriam elegíveis para os "cargos de senador, deputado geral, membro da assembleia provincial, vereador, juiz de paz e quaisquer outros criados por lei” todos os cidadãos habilitados a votar, com as restrições etárias de 25 e 40 anos para deputados e senadores, respectivamente, e, no caso dos cargos provinciais e municipais, com a obrigação de residência na localidade por um certo período de tempo, o projeto substitutivo excluía essas possibilidades, indicando que o texto da Constituição deveria seguir inspirando tais itens, com as restrições, já acima citadas, a libertos, cidadãos naturalizados e aqueles que não professassem a "Religião do Estado"; ${ }^{197}$ além de exigir

193 Representantes de Bahia, Rio de Janeiro e Pará, respectivamente.

194 AS. 27/09/1880, pp. 385-426.

195 Ibid, p. 398.

196 Ibid., p. 398. Os artigos 91 e 92 determinavam quem teria direito ao voto nas eleições primárias, isto é, todos os cidadãos brasileiros e naturalizados no gozo de seus direitos políticos, e quem seria delas excluído, isto é, os menores de 25 anos, os filhos famílias, os criados de servir, os religiosos que vivessem em comunidade claustral, além daqueles que não gozassem da renda líquida anual de cem mil réis, posteriormente ampliada. A tais exclusões, o projeto alternativo da Comissão de Constituição acrescentava as praças de pré do Exército, da armada e dos corpos policiais, bem como os serventes das repartições e estabelecimentos públicos.

197 O texto da Constituição restringia a elegibilidade de libertos, não católicos e cidadãos naturalizados a 
renda mínima que era o dobro daquela do eleitor, ou seja, 800 mil réis para candidatos a deputados. $^{198}$

Outro ponto importante que o projeto substitutivo pretendeu "corrigir" foi a organização dos pleitos, especialmente no que dizia respeito ao alistamento eleitoral. ${ }^{199} \mathrm{Se}$ o projeto Saraiva incentivava o protagonismo das autoridades locais eleitas na qualificação dos eleitores, as emendas da Comissão liderada pelo barão de Cotegipe entregavam, definitivamente, aos juízes municipais e de direito o papel mais relevante em tal processo. ${ }^{200}$ Se o envolvimento definitivo do judiciário na qualificação dos eleitores tinha como objetivo o combate a fraudes, ${ }^{201}$ a opção por magistrados diretamente submetidos aos governos central e provincial revelavam uma disposição contrária à lógica do selfgovernment inscrita nas previsões do projeto original de Saraiva, historicamente defendida por seu partido. ${ }^{202}$ Deste modo, obrigados a aceitar o voto distrital, do qual o presidente do Conselho declarara não abrir mão, ${ }^{203}$ os conservadores tentaram estreitar os horizontes descentralizadores da reforma investindo na participação ativa do governo central na organização e condução dos pleitos. E foram bem-sucedidos.

De fato, o voto distrital foi mantido na letra final da lei, como também o foram as mudanças no alistamento eleitoral. ${ }^{204}$ Outro ponto fortemente ilustrativo do caráter

cargos públicos. Cf. Adriano Campanhole e Hilton Lobo Campanhole, op. cit. Como mencionado mais acima, a lei eleitoral de 1846, aprovada por governo liberal, havia eliminado tal restrição a cidadãos naturalizados e não católicos nas eleições municipais, o que foi revogado pela Lei do Terço, de 1875.

198 AS. 27/09/1880, p. 402. “A comissão eliminou tudo quanto se refere à capacidade eleitoral para deputado, por ser evidentemente, matéria constitucional”. Ibid., p. 386. Note-se que a Constituição dispunha apenas sobre os elegíveis ao cargo de deputados gerais. Houve também novos requisitos para o alistamento que criavam dificuldades aos cidadãos que quisessem tomar parte nos pleitos, como a exigência de apresentarem requisições por escrito a fim de serem incluídos nas listas eleitorais, que foi mantida na letra final da lei. Outras mudanças importantes parecem ter sido altamente restritivas. Na lei, exigia-se, por exemplo, que, para votarem, negociantes, guarda-livros, primeiros caixeiros de casas comerciais e administradores de fábrica industrial provassem que os estabelecimentos onde trabalhavam tivessem capital de, no mínimo, valores próximos a 7 contos de réis, enquanto no projeto original bastava estarem inscritos, desde um ano antes, no registro do comércio. Ibid., pp. 389-394.

199 Ibid., pp. 393-399.

200 “O alistamento dos eleitores será preparado em cada termo pelo respectivo juiz municipal e definitivamente organizado por comarcas pelos juízes de direito destas”. Ibid., p. 393.

201 Cf. Miriam Dolhnikoff, "Governo representativo e legislação eleitoral no Brasil do século XIX”.

202 Esta tensão entre uma lógica de organização do Estado inspirada no self-gorvernment anglo-saxão e outra influenciada pelo "sistema hierárquico de inspiração francesa" acompanhou, segundo indica Monica Dantas, as disputas políticas entre os dois grandes partidos monárquicos nos mais variados âmbitos, ao longo de boa parte do oitocentos. Cf. Monica Duarte Dantas, "O código do processo criminal e a reforma de 1841: dois modelos de organização do Estado (e suas instâncias de negociação)". Conferência apresentada junto ao IV Congresso do Instituto Brasileiro de História do Direito, São Paulo, Faculdade de Direito/USP, 2009.

203 ACD. 04/06/1880, pp. 34-43.

204 Por sua vez, as mesas eleitorais, responsáveis por coordenar a assembleia eleitoral, no dia da votação, seriam compostas, similarmente ao disposto na lei de 1846, pelo "juiz de paz mais votado da sede da 
negociado da Lei Saraiva foi a considerável restrição aos direitos políticos, no que dizia respeito à elegibilidade. Se, como vimos, o projeto original garantia a todos aqueles que podiam ser eleitores a elegibilidade a cargos locais, provinciais, bem como ao Legislativo nacional, com restrições concernentes, especialmente, à idade e ao tempo de residência na localidade, as disposições da lei se mostraram bastante mais restritivas. Não tão restritivas, é verdade, como queriam os conservadores, que não desejavam mudanças em tal ponto em relação à legislação então vigente, o que aponta para o fato de que esse artigo foi resultado de compromisso após intensa negociação:

Art. 10. É elegível para os cargos de Senador, Deputado à Assembleia Geral, membro de Assembleia Legislativa Provincial, vereador e juiz de paz todo cidadão que for eleitor nos termos do art. $2^{\circ}$ desta lei, não se achando pronunciado em processo criminal, e salvas as disposições especiais que se seguem:

$\S 1^{\circ}$ Requer-se:

Para Senador: a idade de 40 anos para cima e a renda anual de 1:600\$ por bens de raiz, indústria, comércio ou emprego;

Para membro de Assembleia Legislativa Provincial: o domicílio na província por mais de dois anos.

Para vereador e juiz de paz: o domicílio no município e distrito por mais de dois anos.

$\S 2^{\circ}$ Os cidadãos naturalizados não são, porém, elegíveis para o cargo de Deputado à Assembleia Geral sem terem seis anos de residência no Império, depois da naturalização. ${ }^{205}$

Pelo que foi exposto até aqui, percebe-se que o debate envolvido na discussão da eleição direta estava intimamente ligado aos temas que haviam dominado as desavenças em torno do sistema eleitoral desde o advento do Império do Brasil. Constituindo verdadeiros pomos de discórdia entre modelos distintos de organização do Estado, tais temas envolviam os partidos políticos em intensos embates. Embates esses que, a partir do reconhecimento da legitimidade do Estado imperial e de seus espaços de negociação, eram realizados na tribuna e nos bastidores do Parlamento, demandando a busca de compromisso entre os partidos, por maiores que se mostrassem as distâncias ente suas demandas. Isto porque o sucesso de qualquer legislação estava intrinsecamente ligado ao reconhecimento de sua legitimidade por ambos os partidos políticos com representação no

paróquia ou do distrito de paz, como presidente, [...] e de quatro membros, que serão: os dois juízes de paz que àquele se seguirem em votos, e os dois cidadãos imediatos em votos ao $4^{\circ}$ juiz de paz". Cf. Francisco Belisário Soares de Souza, op. cit., p. 352.

205 Ibid., p. 347. Essas mudanças tiveram origem em novas emendas realizadas pela comissão liderada por Cotegipe, que tentara também barrar a elegibilidade de libertos, não católicos e naturalizados, no que foi malsucedida. AS. 20/12/1880, p. 200. 
Poder Legislativo. Sem isto, lei eleitoral alguma poderia ter sucesso.

Deste modo, a Lei Saraiva, se não foi uma lei "democrática", como exigiria o olhar de um observador do século XX, foi uma lei liberal. Não apenas por ter sido realizada num país de instituições liberais, mas por ter sido realizada pelo partido político que, ao defender uma agenda marcadamente reformista, assim se intitulava. Ao adotar o censo constitucional do votante, por mais que a inclusão efetiva de centenas milhares deles no novo sistema eleitoral tenha sido mais abstrata do que concreta, ${ }^{206}$ ao restabelecer os distritos uninominais, fortalecendo as localidades em detrimento das elites provinciais e nacionais, ao recusar-se a criar categorias engessadas de cidadãos ativos (no que dizia respeito à elegibilidade), a Lei Saraiva provavelmente não poderia ter sido obra conservadora. Por outro lado, este partido soube se utilizar de sua posição privilegiada na câmara alta para impor restrições e moderar o caráter descentralizador e levemente igualitário da lei. Da intensa negociação nasceu um compromisso, que esteve longe de significar que a fronteira entre os dois grandes partidos políticos do Império era turva. Concordavam quando se tratava de reclamar ao Parlamento suas prerrogativas e resistir às demandas do chefe do Estado, mas parecem ter frequentemente discordado em quase todo resto.

O embate de princípios, de fato, reverberaria nas nada abstratas lutas políticas e na conflagrada realidade material do país ao longo da década de 1880. De um lado, estavam setores do Partido Liberal cada dia mais radicalizados, recuperando e aprofundando uma

206 Como aponta José Murilo de Carvalho, Cidadania no Brasil: o longo caminho. Rio de Janeiro: Civilização Brasileira, 2001, p. 30, após a lei, uma multidão de votantes perdeu a capacidade efetiva de participar das eleições. Não é possível ignorar, nesse sentido, que parece contraditória a afirmação de que uma lei que excluiu, de fato, centenas de milhares de brasileiros do processo eleitoral tenha sido uma lei liberal e moderadamente inclusiva. Algumas observações podem ser feitas a respeito de tal objeção. A primeira, mais imediata, relaciona-se com o papel do votante nas eleições indiretas. Como afirma Miriam Dolhnikoff, apesar de ser "uma forma de incluir setores mais amplos da população no jogo político", o papel do votante era, por natureza, diferente daquele do eleitor, sendo o primeiro ligado à mera legitimação dos pleitos e o segundo à efetiva decisão política. A segunda observação, de caráter mais geral, diz respeito à concepção de que "a participação eleitoral deve se estender a todos, associando representação política com ampla representatividade e inclusão social”, um fenômeno que começou a se tornar realidade apenas no final do oitocentos. Cf. Miriam Dolhnikoff, "Representação na monarquia brasileira", pp. 43-44. Assim, não é exato chamar genericamente de "eleitorado" grupos de cidadãos que, objetivamente, tinham papéis distintos, em forma e conteúdo, nos pleitos. "Ora”, aponta a mesma autora, "se for tomado apenas o número de eleitores e não o de votantes no Brasil, antes da lei de 1881 ele era bem mais baixo [do que o de votantes]: 0,2\% da população em 1873. Nesse sentido, houve uma ampliação da participação dos eleitores que votavam nos deputados e senadores de $0,2 \%$ para $1,2 \%$ que com certeza teve repercussão na relação de representação". Id., "Governo representativo e legislação eleitoral no Brasil do século XIX”. Nas eleições posteriores à lei Saraiva o número de cidadãos aptos a votar esteve geralmente numa margem próxima a 150 mil pessoas, número menor do que haviam previsto alguns de seus apoiadores. 
agenda "democrática" cuja prioridade era a ampliação dos direitos de cidadania. De outro lado, a tentativa de resistência de um Partido Conservador crescentemente cindido às investidas contra o status quo. Porém, para além de todas as coisas, o que fez da década de 1880 um período tão singular na história política imperial se encontrava fora dos salões da alta política. Enquanto as disputas em torno da reforma do sistema eleitoral monopolizavam as atenções dos homens de Estado, nas ruas do Rio de Janeiro fervilhavam a revolta e a insatisfação de uma população que se preparava para dar um novo passo na longa luta pelo direito de intervir nos negócios públicos do Estado brasileiro. A elite política teve que aprender a dividir suas atenções.

\section{4 - Os novos rumos da política imperial na década de 1880}

Em curto espaço de tempo após a derrota sofrida no Senado pelo ministério Sinimbu, mais especificamente de seu projeto de reforma eleitoral por via constitucional, um novo revés se abateu sobre o governo. Num momento em que o país lidava com graves dificuldades econômicas e deficit crescente, o então ministro da Fazenda, o senador mineiro Afonso Celso de Assis Figueiredo, encontrou nas cobranças de impostos sobre as passagens de bonde da capital do Império uma medida capaz de auxiliar na recuperação do tesouro. Ficava previsto, por tal iniciativa governamental, que as empresas que prestavam serviços de transporte público na Corte ficariam isentas de qualquer prejuízo, incindindo nos usuários os custos da nova imposição que introduziria a cobrança de tarifas, no valor de um vintém, ou 20 réis, sobre as passagens de bonde, até então gratuitas. O que poderia, em outros tempos, passar como um simples expediente administrativo - a introdução de um novo agravo que incidia diretamente no orçamento de cada cidadão -, tornou-se um acontecimento político de primeira ordem, tendo sido o estopim do maior movimento urbano de rebelião popular testemunhado no Segundo Reinado. ${ }^{207}$ Abordar os motivos da gravidade alcançada por tais eventos pode auxiliar na compreensão da própria natureza da política imperial naqueles tempos incertos, e nas mudanças que se realizavam, mais ou menos silenciosamente, nas sensibilidades e expectativas de setores importantes da população brasileira.

207 Segue-se aqui a interpretação de Sandra Lauderdale Graham, "O Motim do Vintém e a cultura política do Rio de Janeiro, 1880", in: Monica Duarte Dantas (org.), Revoltas, motins, revoluções: homens livres pobres e libertos no Brasil do século XIX, São Paulo: Alameda, 2011, pp. 485-510. 
Os antecedentes imediatos do Motim do Vintém, que se iniciou na manhã do primeiro dia da década final do Império, data em que estava prevista a implementação da nova tarifa, localizam-se temporalmente algumas semanas antes do final do ano de 1879. A notícia da medida governamental, já aprovada pelo Parlamento em outubro, passou a ser criticada por parte da imprensa e militantes de cores políticas distintas imediatamente após sua publicização, ao mesmo tempo em que setores do Partido Liberal alertavam o ministro da Fazenda para as possíveis consequências negativas de tal medida. No final do mês de dezembro, um grupo estimado em quatro a cinco mil cidadãos "respeitáveis" tentaram reunir-se pacificamente às portas da residência imperial em São Cristóvão para reivindicar do monarca o veto às pretensões do gabinete. Bloqueado o acesso ao paço pela força pública, entretanto, o comício foi dispersado. ${ }^{208} \mathrm{O}$ insucesso das petições e das campanhas veiculadas pela imprensa contra o imposto acabou por radicalizar a oposição, ou, ao menos, proporcionar maior espaço a discursos radicalizados que utilizaram a contrariedade de parcelas amplas da população para aprofundar e tornar mais incisivos os ataques ao projeto, levando à tona um repertório crítico que ultrapassava as ações imediatas do governo e acabou por envolver todo o sistema político do país num agitação de proporções consideráveis. $^{209}$

A radicalização da situação se evidenciou já no dia do início da cobrança da tarifa, $1^{\circ}$ de janeiro de 1880, quando manifestações contrárias ao imposto se transformaram, ao longo do dia, em verdadeiras batalhas campais. A repressão policial não foi capaz de conter a fúria dos milhares de manifestantes, e centenas de praças do Exército foram mobilizadas. Os dias de confronto tiveram um saldo de mortos, feridos e dezenas de edificações e bondes depredados ou destruídos. A tarifa, nos dias seguintes, deixou, na prática, de ser cobrada. ${ }^{210}$ É possível enxergar os eventos daqueles dias sob dois prismas: um ligado aos acontecimentos políticos imediatos, isto é, seu reflexo na composição ministerial e na balança de poder no Legislativo e no Executivo nos meses que se seguiram; e outro, de longo alcance, relacionado às mudanças de fundo que se anunciavam e

208 Ibid., pp. 490-492.

209 No alcance transformador que atribui ao Motim nos alicerces tradicionais da política imperial, Sandra L. Graham destoa de interpretações clássicas que geralmente abordam a revolta sob pontos de vista que limitam seu impacto ao declínio do prestígio de Sinimbu ou como expressão pontual da crise do regime, afirmando ter contribuindo, a revolta, não apenas para a derrocada do gabinete, mas também para disseminação de um discurso de crítica e oposição ao regime entre as camadas populares, amplamente instrumentalizado pelos republicanos. Ver, entre outros, Sérgio Buarque de Holanda, Do Império à República, pp. 234-236; José Murilo de Carvalho, Os bestializados: o Rio de Janeiro e a República que não foi, São Paulo: Companhia das Letras, 1987, pp. 127-128;

210 Cf. Sandra L. Graham, op. cit., p. 492. 
impactariam de forma inédita os alicerces político-institucionais do país.

O recesso parlamentar, entre o fim de 1879 e os primeiros meses de 1880 , que já nada fazia para melhorar a situação política do governo de Sinimbu, ganhou um novo componente de tensão que acabou por ajudar a comprometer a sobrevivência do ministério. Aos dissidentes, a revolta popular dos primeiros dias de 1880 se apresentou como uma nova oportunidade para renovar os ataques ao gabinete que esperava conseguir do Imperador a dissolução da Câmara dos Deputados até que fosse aprovado o projeto de reforma eleitoral, por vias constitucionais, em ambas as casas do Parlamento. Oito destacados opositores de Sinimbu lançaram, ainda sob o impacto dos combates de rua, um manifesto condenando as ações das forças de repressão do Estado e defendendo o direito de manifestação popular contra uma imposição considerada injusta. Destes parlamentares, sete eram liberais, os senadores José Inácio Silveira da Mota e Francisco Otaviano de Almeida Rosa e os deputados Carlos Leôncio de Carvalho, José da Costa Azevedo (futuro barão do Ladário), Joaquim Batista Pereira, Joaquim Nabuco e Joaquim Saldanha Marinho, e um era conservador, Antônio Marcelino Nunes Gonçalves. ${ }^{211}$ Todos se colocavam no campo adversário ao do ministério e sua "Constituinte constituída", defendendo que a reforma da eleição direta, como a queria Sinimbu, seria profundamente restritiva aos direitos políticos da maior parte da população, além de não garantir ao Poder Legislativo independência de ação suficiente. Oferecendo, em face da "arbitrariedade e dos crimes do governo" seu apoio "ao povo sofredor", os oposicionistas lavraram seu protesto em favor "de todos os perseguidos pela polícia", numa ocasião em que eram "atropelados todos os direitos". 212

De acordo com Lauderdale Graham, o impacto de tal manifesto não pode ser subestimado. Além de constituir uma "atitude de contestação sem precedentes", o apoio à causa popular por parte de políticos de alta monta significava também que, ao identificar em setores da população urbana, prontos para a ação política direta, uma fonte de poder, os oito parlamentares contribuíram para estabelecer uma relação íntima entre a revolta das ruas e os embates que dominavam o Parlamento, ligados inevitavelmente à reforma

211 Ibid., p. 496; Barão de Javari, op. cit. Carlos Leôncio de Carvalho havia, em junho de 1879, abandonado o ministério Sinimbu. Os termos favoráveis com que recebeu o gabinete Saraiva e seu "democrático" projeto de reforma eleitoral, além das críticas que teceu à política do governo predecessor, afirmando ter estado muito aquém do programa do Partido Liberal, indicam que os motivos para sua ruptura com o senador alagoano não se distanciavam daqueles que haviam levado à saída de Silveira Martins, meses antes, do mesmo ministério. ACD. 22/04/1880, pp. 10-12.

212 Para a reprodução do manifesto, ver: Correio Paulistano. 06/01/1880, p. 1. 
eleitoral. $^{213}$

Nesse sentido, parece mais do que coincidência que, ainda no mês de janeiro, "fizeram-se as primeiras tentativas, com anuência de Sinimbu, para a substituição do ministério". ${ }^{214}$ Poucas semanas depois, o mesmo Sinimbu que, quando assumira a presidência do Conselho, cerca de dois anos antes, se dissera disposto a efetuar a reforma eleitoral, mesmo que por meio de "reforma constitucional à custa de 3 dissoluções", 215 dirigia-se a Saraiva para convidá-lo a organizar novo ministério. Incapaz de vencer a "oposição pessoal” que lhe impunham "conservadores e alguns liberais", Sinimbu apelava para um estadista que inspirasse "confiança ao partido" e "respeito aos adversários", até por ser "pessoa de fora" e não estar "diretamente comprometido nos fatos passados", para realizar a importante reforma. ${ }^{216}$ Enquanto, portanto, a imprensa ainda dava como iminente a dissolução da câmara temporária, ${ }^{217}$ já estava patente, nos bastidores da alta política, a inviabilidade da manutenção de Sinimbu à frente do Executivo.

Quando, já em abril, Saraiva finalmente chegou ao governo, foi com um projeto de reforma eleitoral formal e substancialmente distinto daquele do ministério anterior, estabelecendo voto distrital e estendendo direitos políticos a libertos, não católicos e cidadãos naturalizados, a ser alcançado por vias parlamentares convencionais. "Havia", afirma Lauderdale Graham, "uma ligação direta entre a revolta de 1880 e o possível sucesso desse projeto, pois que era apoiado, entre outros, por Francisco Otaviano de Almeida Rosa, Joaquim Saldanha Marinho e Joaquim Nabuco, todos membros do grupo da rua do Carmo", que havia lançado o manifesto em apoio às reivindicações da população. ${ }^{218}$ Nesse sentido, Saraiva fez questão de explicitar seu afastamento da política de Sinimbu, afirmando, já na posição de presidente do Conselho, que também teria se recusado a pagar o imposto do vintém caso se encontrasse na Corte no início do ano. ${ }^{219}$ Poucos meses depois, o governo suspenderia a medida definitivamente.

É possível, então, de acordo com as sugestões de Lauderdale Graham, aventar a existência de ligação direta entre as lutas ocorridas dentro do Parlamento e nas ruas da

213 Cf. Sandra L. Graham, op. cit., pp. 496-498.

214 Cf. Sérgio Buarque de Holanda, Do Império à República, p. 237.

215 Sinimbu a Saraiva, 06/01/1878. AIHGB. Col. Saraiva, DL 270.37, doc. 9.

216Sinimbu a Saraiva, 23/02/1880. AIHGB. Col. Saraiva, DL 270.38, doc. 3. Grifo no original. Como vimos,

o Imperador tentara sondar a possibilidade de Saraiva assumir a presidência do Conselho, comprometendo-se com o projeto de reforma constitucional. O esforço foi baldado.

217 Ver, por exemplo, a Gazeta de Notícias, na primeira metade de março de 1880.

218 Cf. Sandra L. Graham, op. cit., p. 503.

219 Ibid., p. 502. 
Corte, fato inédito, até então, para a autora, na longa história do Segundo Reinado. ${ }^{220} \mathrm{O}$ projeto apresentado por Saraiva contemplava significativamente a dissidência do Partido Liberal, que ganhara prestígio e influência na mesma proporção em que o gabinete Sinimbu definhava. De fato, Saraiva deixou claro a seu predecessor que, se não incluiria os dissidentes na nova composição ministerial, ${ }^{221}$ também não deixaria de procurar seu apoio e a união de todos os correligionários, por julgar que "a sorte do partido liberal depende de todos nós". 222 Por um lado, se evitava a "Constituinte constituída", tão criticada por José Bonifácio, recém-nomeado senador por São Paulo, e seus colegas, garantindo que a discussão e emenda do projeto caberia exclusivamente ao Parlamento, sem intervenção do monarca, o que, como vimos, Dantas comemorou como uma grande vitória do "sistema representativo no Brasil". ${ }^{223}$ Por outro lado, e era o que apelava ainda mais a esse grupo, garantia-se o censo do votante e eliminavam-se as restrições constitucionais a libertos, cidadãos naturalizados e os que não professassem a fé católica no que se referia à participação plena nas eleições.

Similarmente, ainda para Lauderdale Graham, a discussão sobre a “questão servil”, até então "fundamentalmente de âmbito legislativo", seria levada a público pelos abolicionistas, que perceberam nessa "outra dimensão da política”, desvelada pelo Motim do Vintém, um imenso potencial; isto é, ultrapassando o âmbito parlamentar, os abolicionistas saberiam utilizar "o ambiente político que se criara" para apresentar a sua causa "a uma plateia mais ampla", recorrendo a um expediente que auxiliaria na popularização da política, arrancando-a dos espaços tradicionais. ${ }^{224}$ Foi na primeira metade da década de 1880, lembra a autora, que se iniciou a proliferação de associações abolicionistas, sendo que, nesse mesmo período, foi fundada a Confederação Abolicionista

220 O reconhecimento crescente da relevância do Motim do Vintém é ilustrado pelo surgimento de estudos recentes que, dialogando com Lauderdale Graham, se dedicam a avaliá-lo sob diferentes perspectivas e partindo de bases teóricas distintas. Ver, por exemplo: Eleomar Candido Gonçalves Silva, Cotidiano, política e protesto popular no Rio de Janeiro: 1880-1901. Dissertação de Mestrado em História Comparada, Rio de Janeiro: UFRJ, 2008; Leandro Duarte Montano, Para além de um vintém: diálogos políticos e ação popular no Corte Imperial (1870-1880). Dissertação de Mestrado em História Comparada, Rio de Janeiro: UFRJ, 2009.

221 Além de Saraiva, que encabeçava o gabinete e também ocupava a pasta da Fazenda, compunham-no: barão Homem de Melo, nos Negócios do Império; Manuel Pinto de Souza Dantas, na Justiça; Pedro Luís Pereira de Sousa, nos Negócios Estrangeiros; José Rodrigues de Lima Duarte, na Marinha; visconde de Pelotas, na Guerra; e Manuel Buarque de Macedo, na Agricultura. Cf. Barão de Javari, op. cit., pp. 185186.

222 Saraiva a Sinimbu. Museu Imperial/Ibram/MinC. Col. Sinimbu, I-DGG-27-03-1880-Sar.c 1-2, doc. 1, p. 1

223 Dantas a Saraiva, 07/03/1880. AIHGB. Col. Saraiva, DL 272.39, doc. 1.

224 Cf. Sandra L. Graham, op. cit., p. 503. 
e se intensificou o alcance e o caráter radical da luta contra a escravidão. "Afinal”, observa Lauderdale Graham, "um público politicamente engajado significava a existência de um poder externo ao parlamento". ${ }^{225}$ Nestes termos, conclui a autora, "o Motim do Vintém marca um breve, mas decisivo, momento em que se transforma a compreensão consensual da política".226

Se há uma lacuna na historiografia sobre o impacto das movimentações de homens livres pobres e libertos e sua luta por direitos e cidadania na política do Império, ${ }^{227}$ os historiadores da escravidão têm avançado muito na compreensão da importância dessas forças extraparlamentares e afastadas da política formal não só para o colapso do escravismo, mas também nos arranjos e rearranjos políticos das décadas finais do regime monárquico. ${ }^{228}$ Mais especificamente no que diz respeito ao conflagrado e crítico decênio de 1880, tende-se a enxergá-lo como um momento de expansão e radicalização sem precedentes da luta abolicionista. Dado o escopo do presente estudo, em que se priorizam tais transformações na década final do Império, focaremos nas interpretações que têm destacado essas profundas alterações.

No caso do clássico de Emília Viotti da Costa, a autora identifica a mudança ocorrida a

225 Ibid., p. 503.

226 Ibid., p. 505

227 Por muito tempo, a historiografia se baseou, ao tratar dessa parcela da população, na interpretação célebre de Maria Sylvia de Carvalho Franco, Homens livres na ordem escravocrata (3 ${ }^{\mathrm{a}}$ ed.), São Paulo: Kairós, 1983. Ao abordar a experiência de tais homens como necessariamente presa a relações de dominação pessoal nas quais estariam inconscientemente enredados, a autora influenciou decisivamente interpretações que destacavam sua impossibilidade de ação como sujeitos históricos. Contraponto fundamental a tal visão foi encetado por Maria Odila Leite da Silva Dias, Quotidiano e poder em São Paulo no século XIX (2 ed.), São Paulo: Brasiliense, 1995; Id., "Sociabilidades sem história: votantes pobres no Império, 1824-1881", in: Marcos Cezar de Freitas (org.), Historiografia brasileira em perspectiva, São Paulo: Contexto, 1998, pp. 57-72. A importante linhagem historiográfica inaugurada por Dias, no entanto, privilegia, partindo da história do cotidiano, o desvelamento da complexidade das relações sociais de livres pobres e libertos no período, sem destacar mais diretamente suas demandas por direitos políticos e cidadania. Esforço recente e louvável neste sentido foi o realizado por Monica Duarte Dantas (org.), Revoltas, motins, revoluções: homens livres pobres e libertos no Brasil do século XIX, São Paulo: Alameda, 2011.

228 Essa profícua movimentação da historiografia sobre a escravidão se iniciou de forma sistemática na década de 1980. Ver, entre outros, Maria Helena Pereira Toledo Machado, O plano e o pânico: movimentos sociais na década da abolição ( $2^{\mathrm{a}}$ ed.), São Paulo: Edusp, 2010; Hebe Maria Mattos, Das cores do silêncio: os significados da liberdade no sudeste escravista, Rio de Janeiro: Nova Fronteira, 1998; Célia Maria Marinho de Azevedo, Onda negra, medo branco: o negro no imaginário das elites século XIX, Rio de Janeiro: Paz e Terra, 1987; João José Reis e Eduardo Silva, Negociação e conflito: a resistência negra no Brasil escravista, São Paulo: Companhia das Letras, 1989; Elciene Azevedo, $O$ direito dos escravos. Lutas jurídicas e abolicionismo na província de São Paulo na segunda metade do século XIX. Tese de Doutorado em História, Campinas: Unicamp, 2003; Angela Alonso, Flores, Votos e Balas: o movimento pela abolição da escravidão no Brasil, Tese de Livre-docência, São Paulo: FFLCHUSP, 2012. Remetemos, ainda, à interessante discussão sobre as transformações na historiografia da escravidão realizada por Suely Robles Reis de Queiroz, "Escravidão negra em debate", in Marcos Cezar de Freitas, op. cit., pp. 103-117. 
partir de fins da década de 1870 , em que a opinião pública passou a se mostrar cada vez mais simpática ao repertório antiescravista. ${ }^{229}$ Neste período, os resultados insatisfatórios da Lei do Ventre Livre, seu fracasso em demonstrar-se capaz de extinguir a escravidão num espaço de tempo aceitável acabou, para a autora, por engendrar um reposicionamento das forças políticas. Aqueles que lutaram contra a lei em 1871, combatendo-a por considerarem-na "iníqua, subversiva, perigosa para os senhores", agora a defendiam como a palavra final no processo de emancipação no país, rejeitando qualquer nova medida que viesse acelerar tal processo. Ao mesmo tempo em que "os abolicionistas e mesmo alguns emancipadores mais avançados [...] apontavam sua ineficácia e exigiam novas medidas". 230

Tais novidades se explicam, para Viotti da Costa, pelas mudanças por que passaram as condições socioeconômicas do Império ao longo do tempo. A redução da "base que sustentava o pensamento escravista" ocorria "à medida que se desintegrava o sistema servil e aumentavam as possibilidades para o trabalho livre". ${ }^{231}$ Em outras palavras, as transformações estruturais que, inexoravelmente, atingiam as bases materiais que sustentavam o Estado imperial criavam condições objetivas para a superação do escravismo. A modernização da economia era acompanhada por um processo de urbanização que, em meio a tais transformações estruturais, trazia em seu bojo a expansão de grupos médios geralmente desligados e crescentemente avessos à escravidão e às relações sociais por ela pautadas. Uma sensibilidade antiescravista teria surgido, então, dessas camadas novas essencialmente urbanas, ao mesmo tempo em que no meio rural a decadência do sistema abria as portas para os protestos dos próprios escravizados contra sua condição. ${ }^{232}$

Foi em meio a esse processo, segundo a interpretação da autora, que o movimento abolicionista encorpou-se e radicalizou-se. A "camada menos comprometida com a escravidão", surgida "graças à multiplicação de empresas e profissões liberais" passou a servir de "suporte à ação abolicionista". ${ }^{233}$ Deste modo, o movimento abolicionista que surgiu nas cidades era "essencialmente urbano", e sua expansão para o campo foi posterior, já num momento em que se mostrava necessário desorganizar o trabalho para que fosse

229 Cf. Emília Viotti da Costa, Da senzala à colônia, São Paulo: Difel, 1966, pp. 409 ss. 230 Ibid., p. 400.

231 Ibid., p. 364-365.

232 Ibid., pp. 428-438

233 Ibid., p. 429. 
adiantada a emancipação, visto que "os elementos rurais eram refratários à campanha"; 234 sendo na década de 1880 que se pode identificar a rápida intensificação da ação abolicionista.

Dialogando diretamente com Sandra Lauderdale Graham, Maria Helena Machado se reporta ao marco do Motim do Vintém para realizar importantes observações sobre a alteração do cenário sociopolítico do Brasil a partir dos anos 1880. "Foi no ambiente de uma cidade onde o inchamento populacional", indica Machado, "condenava largas camadas sociais a baixíssimos padrões de habitação e saneamento", e onde o rápido crescimento demográfico e diversificação da população colocavam nos mesmos cortiços e pensões, escravos, libertos, imigrantes e trabalhadores livres pobres que explodiram os "violentos protestos contra o pagamento do imposto sobre a tarifa dos bondes". Conjugada aos movimentos dos cidadãos mais "privilegiados", a revolta urbana dos primeiros dias da década de 1880 marcou, então, a "invasão do cenário político pela arraia-miúda". ${ }^{235}$

Esta complexificação da sociedade imperial informava o também crescentemente complexo movimento abolicionista. Ao lado de cidadãos da "boa sociedade" - políticos, funcionários públicos, advogados, médicos, estudantes, jornalistas - encontravam-se operários, artesãos, trabalhadores portuários, bem como setores marginalizados e "turbulentos" da população. A explosão do número de meetings e manifestações, muitas vezes acompanhados por milhares de pessoas das mais variadas extrações sociais, demonstrava o sucesso do movimento abolicionista no seu apelo às diversas camadas da sociedade. O significado desse processo de popularização da política, no entanto, era mais profundo. Ao auxiliar na abertura de um amplo espaço informal onde se mostrava possível a participação e manifestação política de vozes antes arredadas do espaço público, o abolicionismo passou a ser também moldado por um repertório de demandas que ia muito além da luta contra a escravidão. A ideia da abolição, neste período, se constituiu como uma via de mão dupla: ao mesmo tempo em que informava, era informada pelas reivindicações populares, "um guarda-chuva sob o qual agasalharam-se diferentes tendências e matizes": 236

A ruptura dos códigos de comportamento político, que desde sempre haviam restringido as disputas e diferenças sobre os destinos do país aos estreitos círculos das

234 Ibid., p. 433.

235 Cf. Maria Helena Machado, O plano e o pânico, p. 138.

236 Ibid., pp. 150-151. 
elites, tornava-se perigosamente palpável na atuação de setores abolicionistas. Assumindo uma feição popular e participativa, a campanha abolicionista transgredia um estilo político bem enraizado, colocando na boca do povo as cisões entre as elites econômicas e bem pensantes. Comportamento indesculpável, foram os abolicionistas, em contrapartida, acusados indistintamente de subversivos. ${ }^{237}$

Foi em agosto de 1880, quando o projeto de reforma eleitoral já havia sido aprovado pelos deputados, que Joaquim Nabuco apresentou seu primeiro projeto de emancipação gradual da escravidão ao Parlamento brasileiro. ${ }^{238}$ Prevendo o fim, indenizado, do cativeiro no Brasil, além de outras medidas, o projeto foi o início de uma série de tentativas por parte de Nabuco em incitar a discussão sobre o assunto, obrigando o gabinete Saraiva, que proclamou não "cogitar" do tema, a se posicionar. Se não conseguiu que o projeto fosse adiante, o deputado pernambucano angariou o apoio de 18 correligionários ao requerimento para que sua discussão fosse dada como urgente na ordem do dia da câmara temporária. "Emergia um bloco abolicionista na Câmara". ${ }^{239}$ A capacidade desse abolicionismo parlamentar, unido a outros próceres do movimento, em reconhecer o potencial da mobilização do novo "público politicamente engajado", que havia saído à luz durante o Motim do Vintém, seria decisiva para os novos rumos que tomaria a política imperial nos anos seguintes. Contudo, segundo a interpretação de Angela Alonso, a história extraparlamentar do abolicionismo começou ainda antes das inflexões dos anos 1880. Acompanhemos a argumentação da autora.

Contestando a tese da irrelevância ou tibieza do associativismo no Brasil oitocentista, Alonso, ao estudar as associações antiescravistas formadas no país ao longo daquele século, demonstra a riqueza e diversidade da vida associativa externa às instituições políticas formais. Destaca a autora que, ao menos desde a década de 1840, eram fundadas associações desse tipo, com relativa diversidade de membros e localizadas em diferentes províncias do Império. ${ }^{240}$ Num primeiro momento, até a década de 1870 , este teria sido, no entanto, o que Alonso chama de "associativismo de elite", reunindo figuras da "boa sociedade" ao largo "de partidos e instituições políticas, mas em relação ambivalente com

237 Ibid., p. 159.

238 Cf. Angela Alonso, Flores, Votos e Balas, p. 144.

239 Ibid., pp. 144-145. A autora lista os nomes dos 18 deputados que votaram a favor do pedido de urgência, bem como suas províncias de origem. Entre eles estavam Saldanha Marinho e José da Costa Azevedo, também presentes na reunião da rua do Carmo, acima mencionada.

240 A autora contabiliza, por exemplo, ao menos 18 associações emancipacionistas fundadas apenas entre os anos de 1860 e 1871, em províncias como Bahia, Ceará, Amazonas, Rio Grande do Sul, São Paulo, e na própria Corte. Cf. Angela Alonso, "Associativismo avant la lettre - as sociedades pela abolição da escravidão no Brasil oitocentista”, Sociologias, Porto Alegre, ano 13, n 28, set./dez. 2011, pp. 166-199. 
eles - contestando sem revolucionar". Era um tipo de movimento que prezava pela ordem e que avançava paralelamente ao Parlamento, "usando o espaço público para espalhar panfletos, jornais e cerimônias públicas de ritualização de entrega de cartas de liberdade adquiridas com as doações arrecadadas". ${ }^{241}$

O início da trajetória ascendente do abolicionismo como movimento social organizado tem, para Angela Alonso, relação íntima com os acontecimentos de fins da década de 1860. Seguindo as indicações de José Murilo de Carvalho, ${ }^{242}$ a autora demonstra que, dentre os resultados da inversão partidária de 1868, com a queda da Liga Progressista e a ascensão dos conservadores, esteve o afastamento dos liberais históricos do poder do Estado. De seu exílio político, parte considerável daqueles homens passaram a desferir, então, ataques ferozes não apenas a seus inimigos políticos imediatos, como à própria organização do Estado e suas instituições. Distantes da tribuna parlamentar, esses "radicais" descobriram nas conferências públicas uma alternativa para expor e disseminar críticas e expectativas profundamente reformistas, de cunho até mesmo estrutural. Pouco havia de mais estrutural para a sociedade brasileira daquele período do que a escravidão, e seriam os defensores de sua extinção que descortinariam, de forma inédita, o potencial existente em mobilizar politicamente parcelas significativas da população na consecução de uma causa comum.

Em fins dos anos 1870 e início do decênio seguinte, a disseminação das conferênciasconcerto foi um passo decisivo em tal direção. Entre peças de teatro, apresentações musicais, discursos inflamados e manumissões em série, os abolicionistas passaram a atrair um público cada vez maior e mais diversificado à causa antiescravista. A arte engajada, a imprensa militante, o espaço público tomado por um número crescente de pessoas de origens distintas, o estreitamento de laços entre associações das mais diversas províncias foram o sinal de que o abolicionismo passava por um ponto fundamental de virada. ${ }^{243} \mathrm{~A}$ chegada dos liberais ao poder ajudaria o movimento no seu completo amadurecimento.

É verdade que, apesar de seu programa altamente reformista, o núcleo do Partido Liberal, além de se encontrar dividido, não parecia cogitar, naquele momento, nenhum tipo de ação mais incisiva no sentido de apressar o processo de emancipação, guiado de forma morosa pela pouco eficiente Lei do Ventre Livre. Contudo, além de levar ao Parlamento um punhado de políticos radicais e comprometidos com a promoção da "questão do

\footnotetext{
241 Ibid., p. 176.

242 Cf. José Murilo de Carvalho, As conferências radicais.

243 Cf. Angela Alonso, Flores, Votos e Balas, pp. 115-138.
} 
elemento servil", muitos dos quais apoiaram, como vimos, a iniciativa abolicionista de Nabuco, ${ }^{244}$ a ascensão dos liberais também significou a abertura de um espaço maior de ação aos abolicionistas. Se a postura, com exceção de setores marginalizados do partido, era de silenciar sobre o problema, ao menos a intervenção no sentido da repressão se provava menor.

Os primeiros anos da década de 1880 foram, deste modo, um período de rápida expansão e nacionalização do movimento abolicionista. Intelectualmente, politicamente e numericamente o movimento se encorpava e ganhava influência. Neste período foram fundadas inúmeras sociedades antiescravistas, bem como a Confederação Abolicionista com seu programa ultra-reformista, que ia muito além da simples extinção do cativeiro, prevendo inclusive reforma agrária. Em 1883, Joaquim Nabuco lançava seu clássico $O$ abolicionismo. ${ }^{245}$ No ano seguinte, o Ceará se tornaria a primeira província do Império a declarar-se integralmente emancipada. ${ }^{246}$ Nesse sentido, destaca Alonso,

O ativismo cresceu, na verdade, bipolar, ao Norte como ao Sul, e acompanhou a lógica política mais do que a econômica. O boom associativo aconteceu na situação Liberal, por conta da expectativa criada pelo Partido ao incluir antes a abolição em seu manifesto, porque se constituíra bloco abolicionista no parlamento, mas também porque o governo titubeava em reprimir as conferências-concerto no espaço público. Nesta conjuntura, manifestações e associações abolicionistas cresceram, como cresceu sua base social, para abranger, no dizer de [José do] Patrocínio, 'cidadãos de todas as classes'. O abolicionismo cresceu em perímetro social e geográfico, hora de nacionalização do movimento. ${ }^{247}$

"Nesse miolo dos anos 1880", portanto, “crescimento numérico, expansão geográfica e eficácia política deram ao movimento força para peitar o status quo". ${ }^{248}$ A autora tende, desta forma, a se distanciar de interpretações clássicas do abolicionismo ao encará-lo do ponto de vista das lutas políticas que se travavam no Império. O desenvolvimento econômico e a complexificação social foram é claro, fatores fundamentais no declínio da escravidão. Contudo, a ascensão do abolicionismo como movimento social na virada da década de 1880 se deve, percebe-se na interpretação de Alonso, a uma combinação destes fatores com o reconhecimento de que decisões políticas por parte de um grande número de

244 Ibid., p. 141.

245 Para "O abolicionismo", ver: Evaldo Cabral de Mello (org.), Essencial Joaquim Nabuco, São Paulo: Penguin Classics Companhia das Letras, 2010, pp. 33-109.

246 Cf. Angela Alonso, Flores, Votos e Balas, cap. 5 "Expansão".

247 Ibid., p. 168.

248 Ibid., p. 217. 
atores eram importantíssimas, para além das condições socioeconômicas do país. Utilizando-se da imprensa, de estratégias de mobilização de um número crescente de militantes, de articulações entre associações regionais, do estabelecimento de relações com figuras importantes da política, o movimento se expandia em todas as direções. ${ }^{249}$

Deste modo, se se coloca lado a lado as interpretações de autoras como Sandra Lauderdale Graham, Maria Helena Machado e Angela Alonso, é possível entrever um panorama de inflexão política significativa naquela primeira metade da década de 1880 . Assim sendo, mostra-se fundamental levar em contra três valiosas indicações oferecidas pelas autoras citadas. A primeira delas diz respeito ao surgimento de um "público politicamente engajado" essencialmente urbano e à percepção do potencial de mobilização desse público por parte de setores importantes da elite política imperial. ${ }^{250} \mathrm{~A}$ segunda refere-se à crescente intervenção da "arraia-miúda", com suas reivindicações e expectativas próprias influindo claramente nos destinos do regime, o que parece ter configurado um processo de popularização da política. ${ }^{251}$ Tendo em vista a terceira, importa destacar a relevância atribuída ao movimento abolicionista como catalisador dessas tensões sociais e seu papel como mediador e promotor de uma arejada agenda democrática, que passaria a ter amplo protagonismo nas lutas políticas dos anos $1880 .^{252}$ Expandindo-se ainda mais o escopo historiográfico e levando-se em conta as fontes documentais, é possível realizar algumas considerações, partindo das proposições formuladas pelas autoras.

A relevância política do Motim do Vintém, ao aprofundar as cisões no Partido Liberal, fortalecendo a dissidência em detrimento do ministério, foi daqueles fatos políticos surpreendentes, marcos de transformações tão significativas quanto longevas. Se a intervenção do Imperador e o descontentamento de setores relevantes de ambos os partidos com as perspectivas da reforma eleitoral por vias constitucionais desgastava sobremaneira o governo, a resposta à revolta popular na Corte, amplamente criticada como imprudente e desproporcional, contribuiu para inviabilizar a permanência de Sinimbu na presidência do Conselho de Ministros. Como foi demonstrado mais acima, já nas semanas seguintes às batalhas campais ocorridas nas ruas do Município Neutro, o senador alagoano passou a declarar privadamente a impossibilidade da manutenção do gabinete por ele presidido no

249 Ibid., pp. 86 ss.

250 Cf. Sandra L. Graham, op. cit.

251 Cf. Maria Helena Machado, op. cit.

252 Cf. Angela Alonso, Flores, Votos e Balas. 
poder. ${ }^{253}$ Quando assumiu, Saraiva fez questão de se afastar das ações do gabinete que o precedera, tanto no que se referia à repressão ao Motim, ${ }^{254}$ quanto no que dizia respeito à reforma eleitoral. ${ }^{255}$ Não à toa, portanto, conquistou o apoio de alguns dos mais ferozes críticos de seu antecessor, entre seus correligionários liberais. O senador baiano não escondeu que fazia concessões aos membros mais radicais de seu partido, que chamou de liberais ultra, ao mesmo tempo em que trabalhava numa lei que fosse aceitável a ambas as agremiações políticas representadas no Parlamento.

Já foi acima demonstrado que, além da adoção do censo do votante, o projeto também previa a recuperação do voto distrital uninominal, antiga bandeira liberal. É interessante nesse sentido recuperar a crítica de Paulino de Souza, na carta endereçada a Saraiva, a tal disposição do projeto. Alertando, como vimos, para o fato de que o voto distrital seria derrisório para os partidos, comprometendo sua disciplina interna e sua capacidade de resistir ao governo que, segundo o conservador fluminense, no Brasil já era "tudo", 256 Paulino expunha a importância de partidos coesos e unidos, em que a autoridade de seus líderes prevalecesse sobre o dissenso. A perspectiva do chefe dos "emperrados" estava fortemente enraizada na ideia da ausência de "povo", ou de "forças vivas" na sociedade brasileira, que para não serem avassaladas pelo Estado, precisavam de partidos fortes, autênticos representantes dos interesses legítimos e estáveis da sociedade. ${ }^{257}$

Opostos a essa visão, os liberais, como observou Saraiva, desejavam, com a eleição direta por distritos uninominais, combater o "poder pessoal" dos chefes de partido, incentivando o florescimento da vida local, numa lógica que privilegiava o autogoverno e prezava por parlamentares intimamente ligados e preocupados em representar os interesses mais imediatos de seus eleitores. ${ }^{258}$ Segundo tal lógica, a reforma, ao mesmo tempo em que impediria a "oligarquia", com candidatos que efetivamente deveriam ser selecionados por alguns milhares de cidadãos em cada distrito, evitaria uma preeminência sem contrapartida das elites provinciais e nacionais na condução dos negócios públicos. ${ }^{259}$ Deste modo, num primeiro momento, a "democratização" do voto ficaria para o futuro, privilegiando-se uma transição segura ao novo modelo eleitoral, para que ajustes

253 Sinimbu a Saraiva, 23/02/1880. AIHGB. Col. Saraiva, DL 270.38, doc. 3.

254 Cf. Sandra L. Graham, op. cit., p. 502.

255 ACD. 22/04/1880, pp. 9-10.

256 Paulino de Souza a Saraiva. AIHGB. Col. Saraiva, Lata 277/Doc. 9, 09/04/1880.

257 Ibid.

258 ACD. 04/06/1880, p. 37.

259 AS. 22/10/1880, p. 249. 
necessários, incluindo-se aí a expansão do sufrágio, fossem realizados gradativamente.

Apesar de suas reservas quanto ao voto distrital, Paulino, dentro do compromisso firmado com o governo dos adversários, fez parte da comissão suprapartidária encarregada de realizar a divisão dos distritos eleitorais. ${ }^{260} \mathrm{O}$ teste para o novo sistema eleitoral ocorreu logo em seguida, nas que foram consideradas as eleições mais corretas da história do Império. Saraiva ordenou aos presidentes de província que se abstivessem de prestar qualquer apoio, direto ou indireto, aos candidatos liberais que concorressem ao pleito, mantendo-se totalmente imparciais. O novo modelo eleitoral, junto à atenta supervisão do presidente do Conselho, resultou em eleições consideravelmente competitivas no ano de 1881.

De acordo com Guo-Ping Mao, um dos resultados imediatos do novo sistema foi o crescimento das divisões internas no Partido Liberal. ${ }^{261} \mathrm{O}$ surgimento de candidaturas liberais rivais em diversos distritos eleitorais resultou no aprofundamento de antigas divisões, no surgimento de novas e no acirramento da competição eleitoral. Por outro lado, tal acirramento também foi marcante devido a, como previra Saraiva, uma maior heterogeneidade do eleitorado, que demandava dos candidatos uma atenção inédita à campanha e à proximidade com os eleitores. ${ }^{262} \mathrm{O}$ resultado disso foi uma proliferação generalizada de circulares, artigos em órgãos de imprensa, comícios e outros componentes de campanhas eleitorais aos quais o país não estava acostumado, ao menos não naquela

260 Foi atribuída a quinze destacados políticos a missão de dividir os círculos eleitorais, cada qual sendo responsável por uma ou duas províncias, diferentes daquelas que representavam no Parlamento. Deste modo, o fluminense Paulino de Souza foi o responsável pela divisão dos distritos das províncias de Sergipe e Espírito Santo. Outros conservadores que compuseram a comissão foram: Diogo Velho Cavalcanti de Albuquerque, senador pelo Rio Grande do Norte e responsável pela província da Bahia; Antônio Marcelino Nunes Gonçalves, senador pelo Maranhão e responsável pela divisão do Ceará; Fausto de Aguiar, senador pelo Pará e responsável por Minas Gerais; Francisco do Rego Barros Barreto, senador por Pernambuco e responsável pela divisão da Paraíba; Manuel Francisco Correia, senador pelo Paraná e responsável pela divisão do Piauí; p conde de Baependi, senador pelo Rio de Janeiro e responsável pela província de Pernambuco; Antônio Cândido da Cruz Machado, senador por Minas Gerais e encarregado da divisão distrital do Rio Grande do Sul. Do lado liberal, os membros da comissão foram os seguintes: João Lustosa da Cunha Paranaguá, senador pelo Piauí e responsável pela divisão de Alagoas; Afonso Celso de Assis Figueiredo, senador por Minas Gerais e encarregado das províncias de Mato Grosso e Goiás; Pedro Leão Veloso, senador pela Bahia e incumbido da divisão de Pará e Amazonas; Cristiano Benedito Otoni, senador pelo Espírito Santo e responsável por Paraná e Santa Catarina; Luís Filipe de Sousa Leão, recém-nomeado senador por Pernambuco e encarregado da divisão eleitoral do Rio Grande do Norte; Eduardo de Andrade Pinto, deputado pelo Rio de Janeiro e responsável por São Paulo; e, finalmente, Martinho Álvares da Silva Campos, deputado por Minas Gerais e encarregado da divisão dos distritos eleitorais da província do Rio de Janeiro. Cf. Alexandra do Nascimento Aguiar, As eleições do mérito: campanha eleitoral de 1881. Dissertação de Mestrado em História Social, São Gonçalo: UERJ, 2009, pp. 58-59; Barão de Javari, op. cit.

261 Cf. Guo-Ping Mao, op. cit., pp. 174-195.

262 "As predicted, the new law strenghtened the ties between the Deputies and electors, making the former more sensitive to the needs and feelings of the latter". Ibid., p. 195. 
magnitude. $^{263}$

Ao mesmo tempo, portanto, em que se aplicava uma nova legislação eleitoral que aumentava a competição eleitoral e incentivava o alargamento do debate público, mudanças profundas eram sentidas no tecido social do Império. Em nenhum lugar ficaram mais claros os efeitos no novo ambiente político do que nas grandes cidades. A proliferação de meetings, conferências e comícios foi particularmente intensa em capitais de peso, como o Recife e, é claro, a Corte. ${ }^{264}$ Apesar do número relativamente restrito de eleitores, a tomada do espaço público pela campanha eleitoral parece ter refletido, ao mesmo tempo em que contribuía para exacerbar, um momento de rápida politização de crescentes camadas populares, até porque tais eventos de campanha não se mantinham restritos ao eleitorado, deles tomando parte setores tradicionalmente excluídos da política formal. ${ }^{265}$ Deste modo, ao encetar a aproximação dos candidatos com seus eleitores e suas demandas específicas, ampliar a competição eleitoral, impor limites à influência das tradicionais lideranças partidárias e contribuir para a inclusão de um público urbano mais diversificado no debate político, a eleição direta com distritos uninominais teve papel importante no processo de popularização da política que ocorria no país, muito provavelmente contra as expectativas da maioria de seus propugnadores.

De fato, não poderia prever Saraiva a direção que tomariam os acontecimentos. Contudo, diferentemente do reformismo moderado do presidente do Conselho e da corrente majoritária do Partido Liberal, sua ala mais radical tinha na "democratização" imediata dos direitos políticos uma prioridade. O extremo oposto do grupo de Paulino, para quem o solo do país "vacilava" frente à suposta inexistência de "forças vivas nesta sociedade brasileira", esses radicais argumentavam que tais "forças" não só existiam, como estavam diretamente interessadas na condução dos negócios públicos, sendo a sua exclusão um "erro de sintaxe política". ${ }^{266}$ Os acontecimentos de princípios da década de 1880

263 Ibid., pp. 196-201.

264 "In the urban areas, candidates began catering to the middle class". Ibid., p. 195. Para o assunto, ver também Alexandra do Nascimento Aguiar, op. cit., pp. 66-68. Segundo a autora (p. 68), “[a] eleição de 1881 se diferenciou na forma de persuasão do eleitorado, as circulares e as manifestações públicas com o programa de reformas multiplicaram-se, estabelecendo pela primeira vez um esforço de campanha eleitoral no Brasil".

265 A multiplicação de meetings e a presença de elementos "turbulentos" foram constantemente destacadas pela imprensa da Corte. No dia 31 de outubro de 1881, por exemplo, a Gazeta de Notícias noticiava: "Desde cedo a população mostrava-se agitada e acudia aos vários pontos da cidade para onde haviam sido anunciados os meetings eleitorais. Havia um rumor surdo pela cidade e afirmava-se que a agitação começara ontem, produzindo efeitos que deveriam perturbar a ordem pública". Apud Alexandra do Nascimento Aguiar, op. cit., p. 66.

266 A célebre expressão foi cunhada por José Bonifácio, o Moço, em discurso, proferido em 28 de abril de 
reforçaram sobremaneira seus argumentos e sua posição dentro do Partido Liberal.

Isto ocorria simultaneamente à ascensão e radicalização do movimento abolicionista como primeiro movimento social organizado de que se tem notícia no país. Apelando a um diversificado público urbano, o abolicionismo se tornava uma força política significativa, que rompia com os ritos da política formal e exigia pleno reconhecimento da legitimidade de suas bandeiras. Seus aliados naturais nas instituições eram aqueles homens de Estado que historicamente haviam defendido bandeiras ligadas à democratização do país, entre elas a abolição da escravidão. Não demorou muito para que a grande potencialidade que existia na união das duas forças se tornasse realidade.

Tal aliança entre forças extraparlamentares, crescentemente relevantes no cenário político, e os setores mais avançados do Partido Liberal mostrou-se capaz, em meados da década, de impor ao Parlamento uma agenda política própria, decisiva para que a questão servil se tornasse definitivamente o tema político central. A ascensão de Manuel Pinto de Souza Dantas, estadista que reconhecidamente flutuava entre o núcleo moderado de seu partido e o radicalismo de seus extremos, ${ }^{267}$ à chefia do governo foi o reconhecimento da urgência dessa nova situação política. Não à toa, o ministério Dantas foi alcunhado, ao mesmo tempo por apoiadores e opositores, de "revolucionário". Estes para denunciar seu rompimento com a moderação comum à alta política imperial, aqueles para louvar esta mesma ruptura. Era a evidência semântica do momento crítico em que adentrava o país.

1879, no qual criticou acerbamente o projeto Sinimbu por pretender apagar o "sujeito da oração" representativa, cometendo um grave "erro de sintaxe política". Cf. Sérgio Buarque de Holanda, Do Império à República, p. 206. 267 Cf. Angela Alonso, Flores, Votos e Balas. 


\section{2}

\section{Os partidos e a "questão servil" (1884-1885)}

Um dos efeitos da reforma eleitoral de 1881 foi o arrefecimento da disciplina interna dos partidos políticos, especialmente no que dizia respeito ao Partido Liberal, então no poder. O enfraquecimento da direção partidária se tornou uma realidade frente a parlamentares que, com a adoção do voto distrital uninominal em pleitos de grau único, estavam submetidos a uma variedade de pressões em que os interesses políticos do partido, a nível provincial e nacional, muitas vezes ficavam em segundo plano, frente à necessidade de se atender às expectativas de um eleitorado mais heterogêneo, a quem respondiam por seus mandatos. Isto se refletiu na considerável instabilidade ministerial que se seguiu à aplicação da lei, no pleito de $1881 .^{268}$

O aumento da competição eleitoral, favorecido também pela autoimposta neutralidade dos liberais na eleição, gerou uma Câmara fortemente dividida, em que a minoria conservadora obteve mais de um terço dos assentos. ${ }^{269}$ Arregimentados e mais disciplinados que seus adversários, os conservadores se beneficiaram das divisões internas do Partido Liberal, se unindo a dissidências momentâneas que, heterogêneas em suas composições e motivações, se afastavam do núcleo do governo. Essas alianças de ocasião foram fatais para os quatro gabinetes que sucederam àquele chefiado por José Antônio Saraiva.

Após a realização bem-sucedida da primeira eleição direta do país, o senador baiano apresentou a demissão coletiva do ministério ao Imperador. ${ }^{270}$ Seu substituto na presidência do Conselho foi um importante aliado, o deputado mineiro Martinho Álvares da Silva Campos, que, na posição de líder do governo na Câmara, havia contribuído para a aprovação do projeto de reforma eleitoral. ${ }^{271} \mathrm{O}$ governo Martinho Campos, contudo, foi malsucedido, assistindo à formação de uma aliança entre conservadores e 18 dissidentes de seu partido que, em votação de confiança, angariaram 63 votos, contra 45 favoráveis ao

268 Cf. Sérgio Eduardo Ferraz, op. cit., pp. 171-189.

269 Cf. Barão de Javari, op. cit., pp. 373-379.

270 Cf. Sérgio Eduardo Ferraz, op. cit., p. 179.

271 ACD. Sessão de 1880. 
governo. $^{272}$

O motivo explícito do conflito entre governo e Legislativo se deu em torno da regulamentação da reforma eleitoral. Ciente de que o ministério fazia de tal assunto questão de confiança, o deputado liberal mineiro Inácio Martins apresentou um requerimento de urgência para a discussão do projeto sobre "revisão do alistamento eleitoral". Rodolfo Epifânio de Souza Dantas, ministro do Império, justificou a recusa da urgência de forma incisiva ao afirmar que, desejando o governo a ampliação do sufrágio e sabendo ser este um assunto espinhoso, fazia questão que a câmara votasse as leis orçamentárias para então tratar de forma mais pausada, mediante a manutenção da governabilidade pelo ministério, das mudanças na lei eleitoral. ${ }^{273}$ Derrotado, o gabinete demitiu-se coletivamente após apenas seis meses no poder.

Seu sucessor foi outra figura próxima a Saraiva no Partido Liberal, o visconde de Paranaguá. Na apresentação de seu programa ao Parlamento, Paranaguá afirmou que, pelo fato de terem sido discordâncias quanto à tentativa de reformar a lei eleitoral que haviam encetado a queda do ministério anterior, o novo governo se absteria de levantar tal bandeira, apenas tomando providências para coibir fraudes. ${ }^{274} \mathrm{O}$ restante do programa de Paranaguá tocava em quatro pontos, além da recuperação das finanças do Império: reforma do Poder Judiciário, para torná-lo verdadeiramente "independente" e "imparcial"; descentralização administrativa e fortalecimento da autonomia das Câmaras municipais; alargamento da instrução pública e adiantamento da emancipação dos escravos, com complementos à lei de $1871 .^{275}$

É muito provável que as duas primeiras reformas, do Judiciário ${ }^{276}$ e dos municípios,

272 ACD. 30/06/1882, p. 129.

273 "Ocupado, como se acha, com a discussão dos orçamentos e entendendo que, a tratar-se de reformar a última lei eleitoral, conviria também promover a extensão do direito do sufrágio (apoiados e apartes), o que agora não lhe parece fácil conseguir e não faria senão suscitar longos e prolongados debates, embaraçando assim a marcha das leis de meios, o ministério pensa que não é ainda oportuno o momento para discutir-se o assunto, e por isso adianta-se em pedir a rejeição do requerimento de urgência anunciado pelo nobre deputado. (Apoiados, interrupções e apartes)”. Ibid., pp. 128-129.

274 "Com relação à questão que deu em resultado a retirada do Gabinete 21 de janeiro [Martinho Campos], direi que o Ministério está convencido de que não convém desde já rever a lei eleitoral em suas disposições principais, pois que semelhante revisão acarretaria discussão larga e incompatível com o pouco tempo que nos resta e que deve ser muito aproveitado". Cf. Barão de Javari, op. cit., p. 200, n. 1.

275 Ibid., p. 200-202, n. 1.

276 A reforma do Judiciário era uma importante bandeira liberal desde o fim de 1841, quando os regressistas reformaram o Código de Processo Criminal. Segundo Monica Dantas, nas décadas seguintes à aprovação da medida, "vários projetos foram propostos, visando à sua reformulação - em 1845 e 1848, quando os liberais estavam nos ministérios, e depois em 1854 (sob autoria de Nabuco de Araújo, durante a Conciliação)". A reforma realizada em 1871, durante o governo Rio Branco, separou a polícia da justiça, mas esteve muito longe de satisfazer as demandas liberais. Cf. Monica Duarte Dantas, "O código do 
para além de sua importância intrínseca, também tivessem relação com a questão eleitoral. Se o desejo de amenizar a rigidez da prova de renda, reforçada pelas emendas conservadoras ao projeto enviado pela Câmara ao Senado, em 1881, e ampliar o eleitorado não fora adiante com a derrota de Martinho Campos, parece plausível a hipótese de que Paranaguá tentou realizar mudanças que afetariam os pleitos, ainda que por outras vias. A reforma do Judiciário, tornando-o verdadeiramente independente, e da administração municipal, poderiam ter impacto direto no alistamento do eleitorado que, como vimos, os liberais desejavam que fosse realizado por autoridades locais eletivas, mas que os conservadores conseguiram atribuir aos juízes municipais e de direito, ligados ao governo central e diretamente submetidos ao partido no poder. ${ }^{277}$

O programa moderadamente reformista de Paranaguá e sua propalada disposição em não tratar de temas polêmicos não lhe renderam os frutos esperados. Pelo contrário, menos de um ano após sua chegada ao poder, o gabinete perdeu a votação de uma questão de confiança na Câmara dos Deputados, também graças à aliança pontual entre o Partido Conservador e uma dissidência liberal. Enquanto 53 deputados votaram contra o gabinete, apenas 40 o sustentaram. A controvérsia originou-se de um pedido de adiamento da ordem do dia, realizado pelo deputado pernambucano José Mariano Carneiro da Cunha, até que se desse urgência a uma questão relativa à divisão de rendas entre centro e províncias. ${ }^{278}$

A dissidência que votou contra Paranaguá era quase totalmente distinta daquela que havia derrubado Martinho Campos. Enquanto esta última reunira majoritariamente elementos moderados do Partido Liberal, como Antônio Moreira de Barros e Lourenço Cavalcanti de Albuquerque, os dissidentes contrários a Paranaguá vinham, em grande parte, da ala mais extremada do partido. Entre eles, além de José Mariano, reconhecido abolicionista pernambucano, estavam Rui Barbosa, Rodolfo Dantas e Adriano Pimentel. É possível aventar a hipótese de que, ao evitar tratar explicitamente da reforma da Lei Saraiva, no sentido de expandir o eleitorado, Paranaguá tenha se indisposto com setores do partido que atribuíam ao tema grande urgência.

Para além disso, a agitação abolicionista vinha crescendo rapidamente e a pressão para que o governo apresentasse propostas para a abreviação do cativeiro se intensificava no

processo criminal e a reforma de 1841: dois modelos de organização do Estado (e suas instâncias de negociação)", p. 18.

277 Para as emendas conservadoras à Lei Saraiva, ver a $3^{\mathrm{a}}$ seção do $1^{\circ}$ capítulo da presente dissertação.

278 Cf. Sérgio Eduardo Ferraz, op. cit., pp. 182-185; ACD. 15/05/1883, p. 100. 
Partido Liberal. ${ }^{279} \mathrm{O}$ programa de Paranaguá, contudo, era bastante tímido neste sentido. Além de não explicitar quais medidas seriam tomadas para apressar a emancipação dos escravos, indicava o plano de apenas complementar a Lei do Ventre Livre, já considerada ultrapassada, àquela altura, por grande parte do seu partido.

Mostrando-se cada vez mais graves as fissuras na situação, tornou-se difícil encontrar uma liderança capaz de substituir Paranaguá. Segundo relata Angela Alonso, após a queda do senador pelo Piauí, o Imperador, mediante indicação do ministro demissionário, apelou ao "apagador de incêndios" Saraiva, que se esquivou, afirmando não poder contar com a unidade necessária do partido para a realização de um programa que incluísse medidas concernentes à questão servil. Mais uma vez consultado, Paranaguá evitou indicar aquela que seria a opção natural em se tratando do tema da emancipação dos escravos, o conselheiro Manuel Pinto de Souza Dantas, ${ }^{280}$ sugerindo José Bonifácio como alternativa. Este "melou o boicote" e recomendou Dantas, que, "constrangido", rejeitou o encargo, apontando a impossibilidade de sucesso frente a um Partido Liberal rachado. ${ }^{281}$ De toda a incerteza e aparente abandono dos chefes liberais, surgiu Lafaiete, figura pouco expressiva nos quadros do partido. ${ }^{282}$

O programa do senador mineiro não destoava significativamente daquele apresentado por Paranaguá. Junto da preocupação com as finanças, estavam a reforma da administração municipal e provincial, do Judiciário e do ensino. No que dizia respeito à questão servil, Lafaiete foi um pouco adiante de seu predecessor, expondo claramente duas medidas planejadas pelo gabinete: a localização provincial da escravatura e o "aumento dos recursos do fundo de emancipação", com a criação de "um imposto especial sobre o próprio elemento servil". ${ }^{283}$

Contudo, o ministério Lafaiete não sobreviveu tempo o bastante para levar adiante as reformas pretendidas, caindo cerca de um ano após chegar ao poder. Sua queda foi marcada por uma sucessão de crises e pelo surgimento de novas fissuras na bancada do partido. A abrupta demissão do desgastado ministro da Guerra, o deputado pelo Ceará

279 Segundo indica Angela Alonso, nesse período entre os ministérios Martinho e Paranaguá, figuras destacadas do Partido Liberal, como Gaspar da Silveira Martins e Francisco Otaviano, declararam-se abertamente favoráveis a medidas emancipacionistas avançadas. Cf. Angela Alonso, Flores, Votos e Balas, p. 164.

280 Cf. Angela Alonso, Flores, Votos e Balas, pp. 186-187. Por seu histórico e suas ideias, Dantas seria, afirma Alonso, a opção mais acertada se se quisesse avançar na agenda da emancipação.

281 Ibid., p. 186.

282 Ibid., p. 187.

283 Cf. Barão de Javari, op. cit., p. 209, n. 1. 
Antônio Joaquim Rodrigues Júnior, após o trágico assassinato público do controverso jornalista Apulco de Castro, em fins de $1883,{ }^{284}$ e o agravamento da questão militar, no início do ano seguinte, ${ }^{285}$ parece ter rachado a bancada liberal do Ceará, da qual Rodrigues Júnior era importante liderança. ${ }^{286} \mathrm{O}$ rápido processo de libertação dos escravos na província ajudou a comprometer ainda mais as relações entre parte dos deputados cearenses e o ministério Lafaiete, que prestava apoio tácito ao movimento. ${ }^{287}$

Após seu candidato à presidência da Câmara, o deputado paulista Antônio Moreira de Barros, vencer por margem estreita a eleição da mesa, com o sufrágio de ministros deputados, ${ }^{288}$ a defecção de ex-aliados tornou a situação do governo insustentável. Aristides César Espínola Zama, parlamentar baiano e grande aliado de Saraiva e Dantas, se "bandeou" para a oposição, ${ }^{289}$ apresentando moção de desconfiança ao gabinete. Ao angariar apenas 60 votos, contra 56 da oposição, o governo teve de reconhecer que, contando apenas consigo mesmo, "não dispunha de número para fazer funcionar a câmara". Diante da vulnerabilidade do governo, outro deputado baiano, Rui Barbosa, membro da maioria, propôs o encerramento da sessão. Com a deserção de Afonso Celso de Assis Figueiredo Jr., deputado liberal mineiro, a maioria se tornou insustentável. ${ }^{290}$

O desenrolar dos eventos sugere que a questão do elemento servil, dada a agitação abolicionista e o sucesso da emancipação no Ceará, com perspectiva de que o movimento

284 Apulco de Castro foi uma das figuras mais controversas da imprensa da Corte de então. Por meio de sua folha, $O$ Corsário, o jornalista desferia ataques impiedosos contra os mais diversos alvos, ensaiando a construção de uma crítica radical às instituições e à sociedade imperial. Nos meses finais de sua vida, Castro publicou uma série de editoriais constrangedores contra soldados e oficiais do Exército, lançando acusações que foram consideradas ataques frontais à honra e à dignidade da corporação. Depois de receber ameaças à sua vida, o articulista solicitou proteção das autoridades, o que não impediu que fosse assassinado, pouco depois, por militares mascarados nas ruas do Rio de Janeiro, em plena luz do dia. O caso ganhou grande repercussão e a morte de Castro gerou indignação em setores populares que, aos milhares, se reuniram para protestar contra o ocorrido. A credibilidade do gabinete e, particularmente, do ministro da Guerra, ficou sensivelmente abalada. Sobre o caso Apulco de Castro, ver: Thomas H. Holloway, "The defiant life and forgotten death of Apulco de Castro: race, power and historical memory", E. I. A. L, Vol. 19 - $\mathrm{n}^{\circ} 1$ (2008); John Schulz, O Exército na política: origens da intervenção militar, 1850, 1894, São Paulo: Edusp, 1994, pp. 99-100.

285 Cf. John Schulz, op. cit, pp. 100-101.

286 Segundo informações do deputado pernambucano José Mariano, Rodrigues Júnior contava com o apoio de deputados cearenses e outros liberais que, juntos, formavam "um núcleo de oito oposicionistasdissidentes". A notícia, de acordo com o parlamentar, "transitou pela chancelaria conservadora". José Mariano Carneiro da Cunha a Francisco de Carvalho Soares Brandão, 27/03/1884. AIHGB. DL 611.37, doc. 3.

287 A Gazeta de Notícias fez diversas observações nesse sentido no início do mês de junho de 1884, quando agonizava o ministério Lafaiete.

288 O concorrente de Moreira de Barros foi Rodrigues Júnior, que angariou 57 votos, de conservadores e dissidentes, contra 59 do deputado paulista. Cf. Sérgio Eduardo Ferraz, op. cit., p. 187.

289 Gazeta de Notícias. 03/06/1884, p. 1.

290 Gazeta de Notícias. 04/06/1884, p. 1. 
libertador se expandisse em direção a outras províncias, a começar pelo Amazonas, ${ }^{291}$ passava a ocupar papel preeminente na agenda política do país, deixando em segundo plano a questão eleitoral e a reforma do Estado, que nos primeiros anos da década ocuparam os governos liberais.

Deste modo, o senador baiano Manuel Pinto de Souza Dantas chegou ao poder, após a queda de Lafaiete, num ápice de agitação popular inflamada por um gigantesco triunfo, mais do que ilustrativo da dimensão e nível de organização que atingia o movimento abolicionista brasileiro. A libertação do Ceará foi marcada por uma estratégia tão original, na sua complexidade, quanto bem-sucedida, na velocidade com que decretou a extinção do cativeiro naquela província. Foi lá que uma aliança entre governo e movimento abolicionista demonstrou pela primeira vez seu grande potencial, possibilitada pela ação do presidente Sátiro Dias, indicado por Dantas ao ministério Lafaiete. ${ }^{292}$ Nesse contexto, não parecia mais prudente, ou desejável, a uma parcela considerável dos homens de Estado de então, ignorar as vozes que vinham das ruas, dos teatros e da imprensa. Política e pragmatismo, irmãos geralmente inseparáveis, engajaram-se numa união visceral.

\section{1 - O projeto de 15 de julho e a dissolução da Câmara dos Deputados}

Antes que Dantas apresentasse o programa de seu governo ao Senado, Saraiva, que, mais uma vez, rejeitara o convite imperial para organizar gabinete, levantou-se para justificar o porquê de sua recusa. As palavras do senador baiano tomaram de surpresa muitos dos políticos então reunidos, revelando que, pela primeira vez desde o início da década anterior, um gabinete ascendia tendo a questão da emancipação como parte mais importante de seu programa: "Ponderei a Sua Majestade [...] que não tinha segurança de poder organizar ministério forte e duradouro, capaz de resolver ou encaminhar uma solução satisfatória a questões graves agitadas no parlamento, e fora do parlamento, como a do elemento servil". 293

291 Para o assunto, ver: Angela Alonso, Flores, Votos e Balas, esp. cap. 6 “Abolicionismo de resultados”.

292 Para o processo de abolição no Ceará, ver: Ibid., pp. 196 ss. Antes de Sátiro Dias, Alonso destaca o papel de Sancho de Barros Pimentel, indicado no ano de 1882 para o cargo mais alto da administração da província, em tal processo. O presidente, que era sócio de Rodolfo Dantas e Rui Barbosa, respectivamente filho e afilhado do conselheiro Dantas, além de amigo de Nabuco, patrocinou uma lei que formalmente proibiu a importação e exportação de escravos para o Ceará, ao mesmo tempo em que o valor dos cativos despencava na província, auxiliando na construção de um contexto propício à bemsucedida campanha pela sua libertação.

293 O discurso encontra-se em AS. 09/06/1884, p. 24. 
Segundo Saraiva, a preocupação maior do Imperador estava na condução das eleições que se aproximavam, que desejava que fossem "as mais regulares". Tendo em vista o prestígio de que gozava, no país, o estadista que, na condição de chefe do governo, havia presidido àquelas que haviam sido consideradas as eleições mais corretas da história do Império, habilitava-se, acima de todos, para promover o novo pleito, o segundo a ser realizado após a reforma de 1881. Em nome da "inteira confiança" que lhe inspirava o senador baiano, d. Pedro se comprometera, se aceitasse a incumbência, a não intervir no encaminhamento "da questão do elemento servil" por meio de uma solução que não abalasse "os grandes interesses econômicos do país", prometendo liberdade total de ação ao ministério. Saraiva, contudo, observou não ser justificável a alegada preocupação do Imperador com a condução do pleito, pois, segundo o senador baiano, ambos os partidos haviam se comprometido com a reforma de 1881. Mais ainda, no caso do Partido Liberal, não se podia duvidar do interesse de todos os seus membros em promover eleições irretocáveis, já que tal partido havia pedido, “em dez anos de oposição, a liberdade do voto, e feito uma lei para garanti-la, não poderia, sob pena de tornar-se impopular, deixar de honrar o programa que o elevara ao poder". ${ }^{294}$

Deste modo, a urgência política daquele momento não se relacionava com as eleições, como da primeira e, até então, única vez que Saraiva ocupara a presidência do Conselho. Se, em 1880, o "messias de Pojuca" conseguira unir seu partido e compor com a oposição na consecução da reforma eleitoral, quatro anos depois a situação era outra: a questão servil se assoberbava e o estadista baiano não contava possuir força política suficiente para levar adiante as medidas necessárias. Era preciso "ministério homogêneo, e que, por essa homogeneidade, exercesse no partido liberal eficaz influência", pois "sem apoio forte de seu partido ninguém pode no governo ter segurança de bom êxito, ainda que o pensamento predominante seja uma aspiração nacional”. 295

O relato de Saraiva sobre sua conversa com o monarca permite entrever que o senador baiano deixara implícita, ao chefe do Estado, sua indicação para a presidência do novo gabinete, e que seria explicitada pouco depois por Lafaiete: a sucessão ministerial pertencia a Dantas, que não apenas havia sido ministro da Justiça no gabinete responsável pela eleição direta, como era figura reconhecidamente ligada ao abolicionismo. ${ }^{296} \mathrm{O}$ aliado,

294 Ibid., p. 24.

295 Ibid., p. 24.

296 Dantas possuía um histórico de apoio e ligação à causa da emancipação dos escravos, fazendo parte de associações libertadoras desde muitos antes de alcançar o ápice da política nacional. Além disso, possuía 
amigo e comprovinciano de Saraiva reunia, então, todos os requisitos necessários: compromisso simultâneo com a herança da reforma eleitoral e com a causa da emancipação, que entrava de uma vez por todas na ordem do dia.

O novo compromisso do Partido Liberal, assumido por Dantas, mudava da noite para o dia os ares da política imperial. O presidente do Conselho dividiu seu programa em duas partes principais: resgatar as combalidas finanças do país e apresentar solução à intrincada questão do elemento servil, oferecendo um projeto que, entre outras disposições, localizaria provincialmente a propriedade escrava, ampliaria o fundo de emancipação (criando uma "contribuição nacional" que envolveria todas as "classes da sociedade" no processo de emancipação) e libertaria os escravos maiores de 60 anos. ${ }^{297}$ Além das duas prioridades citadas, integravam o programa do ministério medidas claramente ligadas à reorganização do trabalho, como uma nova lei de locação de serviços, incentivos à imigração e ações no sentido de uma reforma territorial, declarando Dantas sobre este último ponto: “[...] está no pensamento do governo habilitar-se também para proceder à desapropriação de terrenos às margens de nossas estradas de ferro e dos rios navegáveis, à imitação do que já está estabelecido na lei de 1855, e seu regulamento". 298

A mudança considerável de ânimos causada pela apresentação do programa do novo gabinete foi ilustrada em duas folhas da Corte simpáticas ao abolicionismo. A Gazeta de Notícias, que declarara não nutrir expectativas de que a nova organização ministerial teria destino diferente dos malsucedidos gabinetes que a haviam precedido, ${ }^{299}$ demonstrou-se bem mais otimista quando tomou conhecimento das intenções do novo ministério. As propostas genéricas quanto às finanças do Império eram ofuscadas, destacava o articulista, pelo caráter explícito da exposição da reforma servil pretendida: "Ainda em nenhum programa de governo ou fala do trono se tratou tão diretamente desta questão [...]". 300 Outra folha que não tardou em deixar de lado o pessimismo e voltar atrás em suas críticas foi a abolicionista Gazeta da Tarde. Se, no dia em que se formara o novo ministério, o

reputação por defender outras importantes bandeiras reformistas. Ver, por exemplo: Angela Alonso, Flores, Votos e Balas, págs. 40 e 221.

297 AS. 09/06/1884, p. 25.

298 Ibid., p. 19. Dantas provavelmente se referia à lei $\mathrm{n}^{\circ} 816$ de 10 de julho de 1855 , que autorizava o governo "a estabelecer o processo para desapropriação dos prédios e terrenos que forem necessários para a construção das obras e mais serviços pertencentes à Estrada de ferro Dom Pedro Segundo, e às outras estradas de ferro do Brasil, e a marcar regras para a indenização dos proprietários", regulada pelo Decreto $\mathrm{n}^{\mathrm{o}} 1664$, de 20 de outubro do mesmo ano. O programa ministerial também defendia a instituição do casamento civil. 299 Gazeta de Notícias. 09/06/1884, p. 1.

300 Id. 10/06/1884, p. 1. 
jornal declarara-o, graças às divisões do Partido Liberal, natimorto, a repercussão da apresentação de Dantas às câmaras serviu para alterar consideravelmente o tom do órgão de imprensa comandado por José do Patrocínio. Apesar da incerteza que rondava a reforma emancipacionista anunciada, que parecia mais um "paliativo", o jornal celebrava o fato inédito: o gabinete levantara, pela primeira vez, "a questão agrária no Parlamento". 301 Deste modo, a Gazeta da Tarde proporcionaria ao ministério o benefício da dúvida, não dando eco "à hilaridade incivil com que a minoria conservadora recebeu as declarações de desassombro partidário e sinceridade patriótica do Sr. presidente do conselho". ${ }^{302}$

A reação da oposição ao programa de Dantas se foi da repugnância à incredulidade, mal disfarçadas de pouco-caso. A estratégia adotada tomou uma via dupla: questionar a força política do gabinete e sua autoridade dentro do Partido Liberal e destacar a severidade da situação financeira do país, demonstrando a impropriedade de qualquer intervenção na questão servil sem que fosse estancado o persistente sangramento do tesouro deficitário e encaradas as agruras econômicas pelas quais passava o Brasil. No Senado, o representante do Paraná, Manuel Francisco Correia, foi o porta-voz do Partido Conservador. ${ }^{303}$ Correia começou seu discurso estranhando o fato, contraditório na opinião do senador, de Saraiva ter rejeitado o encargo de organizar novo gabinete, alegando não ser a maioria liberal sólida o bastante para a constituição de um governo estável, enquanto Dantas, que no ano anterior havia rejeitado a missão, nos mesmos termos agora a aceitava, a não ser que os termos tivessem mudado. "Que segredo é esse do nobre presidente do conselho", interrogou Correia,

[...] para transformar a situação, que a todos nós se afigura hoje mais complicada que a de 1883, em uma risonha situação em que S. Ex. pode, ao mesmo tempo lançar novos impostos sobre os contribuintes, e resolver de modo satisfatório a questão do elemento servil? Em que repousa a crença atual do nobre presidente do conselho? ${ }^{304}$

Antônio Ferreira Viana foi o escolhido, dentre os deputados conservadores, para iniciar a ofensiva contra o novo ministério na câmara temporária. ${ }^{305}$ Como Correia, o parlamentar fluminense destacou a suposta fraqueza do gabinete Dantas, que afirmou carecer de apoio entre algumas das principais lideranças do Partido Liberal. Em tom

301 Gazeta da Tarde. 10/06/1884, p. 1

302 Ibid., p. 1

303 AS. 09/06/1884, pp. 26-28.

304 Ibid., p. 27.

305 ACD. 09/06/1884, pp. 23-24. 
condescendente, Ferreira Viana afirmou desejar que o novo presidente do Conselho fosse capaz de enfrentar os colossais desafios que se impunham ao país, especialmente no que dizia respeito a suas condições financeiras, mas acabou por assinalar que o frágil ministério não dava sinais de que conseguiria levar adiante tão heroica tarefa:

O nobre presidente do conselho foi enganado, exagerou os seus recursos; a situação não é compatível com o ministério de S. Ex. Se o nobre presidente do conselho pudesse reunir os conselheiros que foram de Sua Majestade com outros que hão de ser, e para isso já foram apalpados em S. Cristóvão, se viesse à câmara reunido com todos eles, talvez o orador acreditasse na possibilidade da execução do seu plano; mas, nas ocasiões em que se acha, divorciado de alguns, com a má vontade e a indiferença de outros, cedo se arrependerá de ter aceito esta incumbência.

$[\ldots]$

Não tem o orador nenhum interesse na sua gerência dos negócios do Estado, e por consequência nenhum infortúnio pode desejar ao nobre presidente do conselho. Não vê, porém, na organização do ministério, no seu programa, nos recursos de que pode dispor ante as circunstâncias excepcionais do país, meios de vitória para o nobre presidente do conselho.

$[\ldots]$

O país está a braços com o deficit, sem pensar no dia de amanhã, sem tomar providências para não ser surpreendido pela explosão. O governo do país tateia nas trevas. ${ }^{306}$

O fatalismo da oposição tinha como alvo evidente perscrutar os pontos fracos do gabinete e provocar a desestabilização de um governo do partido adversário, mas não era desprovido de fundamentos.

A nomeação de Dantas acabou acontecendo, como vimos, após a sugestiva recusa de Saraiva. Mas as fissuras se mantinham, pois, inicialmente, dentro do Partido Liberal, o ministério estava distante de angariar grande simpatia. Sinimbu e Afonso Celso, ouvidos pelo Imperador antes da ascensão do conselheiro Dantas, haviam declarado não cogitar medidas que alterassem a lógica emancipacionista prevista na lei de 1871. O senador mineiro, ministro da Fazenda no governo de seu colega alagoano, entre 1878 e 1880, também relatou ao Senado ter expressado ao monarca sua preocupação com a difícil situação financeira do país, cuja irresolução não permitia que se pensasse em tratar da questão servil. ${ }^{307}$ Nenhum deles parecia entusiasta da nova formação ministerial.

Não é incompreensível a resistência do Imperador e as tergiversações de algumas figuras relevantes do Partido Liberal em apoiar a nomeação do senador baiano à presidência do Conselho. É interessante recordar que, além de d. Pedro, Sinimbu e Afonso

306 Ibid., p. 24.

307 AS. 09/06/1884, pp. 28-29. 
Celso haviam sido derrotados na questão da reforma eleitoral, quatro anos antes, pelo gabinete presidido por Saraiva e no qual Dantas ocupara uma das pastas-chave, a da Justiça. Não parece estranho, então, que sentissem desconforto com sua volta ao governo. Em meio à radicalização da situação, no entanto, as opções escasseavam: se o objetivo emergencial era conter os "excessos" e restabelecer o controle sobre o processo de emancipação, devolvendo-o aos poderes constituídos, em especial ao Parlamento, quem mais indicado que um destacado homem de Estado que tinha considerável trânsito nas fileiras mais avançadas do abolicionismo?

Em sua primeira reunião com o monarca como presidente do Conselho, Dantas conquistou uma vitória e sofreu uma derrota. O Imperador lhe assegurou a dissolução da Câmara, caso ela rejeitasse o gabinete nos termos do projeto do elemento servil, para garantir-lhe liberdade de ação em tal assunto, mas rejeitou a nomeação do afilhado do senador baiano para o ministério. Rui Barbosa, um dos mais ativos defensores do adiantamento da emancipação, que comemorara a derrota de d. Pedro na questão da reforma eleitoral, ${ }^{308}$ de cujo projeto fora relator, agora tinha suas ambições podadas pela Coroa. $^{309}$

A composição ministerial foi criticada por alguns como fraca, com pouca capacidade de angariar apoio suficiente nas fileiras liberais. Entres os ministros havia, além de Dantas, que respondia pela pasta da Fazenda, dois senadores: o visconde de Lamare, representante do Mato Grosso, na pasta da Marinha, e Felipe Franco de Sá, representante do Maranhão, na pasta do Império. Como este último havia substituído Rodrigues Júnior na pasta da Guerra, ainda no gabinete Lafaiete, a bancada cearense manteve-se dividida no seu apoio a Dantas, com a maioria dos liberais daquela província permanecendo, desde o início, numa posição de desconfiança e dubiedade com relação ao ministério. Quatro deputados completavam o gabinete: dois baianos, Francisco Maria Sodré Pereira, na Justiça, e Antônio Carneiro da Rocha, na Agricultura, e dois mineiros, Cândido Luís Maria de Oliveira, na Guerra, e João da Mata Machado, nos Negócios Estrangeiros. ${ }^{310}$ Com três baianos e dois mineiros no gabinete, não era de se estranhar que lideranças importantes do partido se sentissem excluídas. Neste ponto, as observações de Joaquim Nabuco, em carta ao barão de Penedo, são valiosas:

308 Rui Barbosa a Saraiva, 1880. AIHGB. DL 275.5.

309 Cf. Tobias Monteiro, Pesquisas e depoimentos para a História, Belo Horizonte: Editora Itatiaia; São Paulo: Edusp, 1982, p. 49. 310 Cf. Barão de Javari, op. cit., pp. 211-213. 
Está arranjado o Ministério Dantas. [...] Dizem os amigos dele que o Imperador prometeu a dissolução. Eu não creio nisso. Não me parece porém que, sendo essa muito provavelmente a última combinação liberal, os liberais a deixem em vésperas de eleições. Diz-se todavia que o Gaspar [da Silveira Martins] está rugindo e que o [Afonso] Celso e o Sinimbu não estão reconciliados. De Minas entraram com efeito os dois maiores opositores do Celso. ${ }^{311}$

Os únicos que decididamente apoiavam o ministério naquele primeiro momento, ainda segundo Nabuco, eram os mineiros Martinho Campos e Lafaiete. ${ }^{312} \mathrm{O}$ primeiro, como vimos, fora um dos principais sustentadores do projeto de reforma eleitoral de Saraiva e, sucedendo-o na presidência do Conselho, entregara importantes pastas ministeriais a Rodolfo Dantas, Franco de Sá e Carneiro da Rocha, respectivamente filho e então aliados de Dantas. ${ }^{313} \mathrm{O}$ apoio do segundo ao gabinete tem provavelmente relação com o fato de terem sido mantidos alguns de seus principais aliados em posições destacadas no governo. Havia, por outro lado, descontentamento em São Paulo e Pernambuco, províncias preteridas na composição do ministério. ${ }^{314}$ Além disso, o próprio Nabuco se declarava extremamente desesperançoso com o ministério, não considerando ter lá "amigos" que pudessem apoiar uma eventual candidatura sua. Tendo em vista essa intrincada situação, restava ao abolicionista aguardar a sessão de 9 de junho, que haveria de "esclarecer muita coisa". ${ }^{315}$ De fato, esclareceu.

"A declaração do Saraiva de que não organizara por não poder constituir um ministério homogêneo capaz de resolver a questão do elemento servil”, declarava um radiante Nabuco exatamente duas semanas após a apresentação do ministério Dantas ao Parlamento, "abriu uma nova época em nossa história". ${ }^{316}$ Nabuco elogiava o presidente do

311 Joaquim Nabuco ao barão de Penedo. Biblioteca Nacional. Arquivo Tobias Monteiro. 63,03,005 n 31, [S. 1.], 07/06/1884. 2p.

312 Ibid.

313 Cf. Barão de Javari, op. cit., pp. 191-192. Como veremos, Martinho Campos se distanciou decididamente do ministério após ficaram explícitos seus planos e procedimentos quanto à questão servil.

314 Joaquim Nabuco ao barão de Penedo, 07/06/1884. Biblioteca Nacional. Arquivo Tobias Monteiro. 63,03,005 no 31, [S. 1.], 2p.

315 Ibid. Sobre Dantas, é possível que as "queixas" que Nabuco declarava terem um do outro estivessem relacionadas ainda ao mal estar causado pelo abolicionista pernambucano, no princípio da década, por sua insistência na questão servil, quando o governo, assoberbado pela reforma eleitoral, dela não cogitava. Realmente, Nabuco foi deixado de lado nas eleições que se seguiram, apesar do apoio prestado à reforma do sistema eleitoral. A derrota de sua candidatura, carente de sustentação no partido, resultou num autoexílio de quase três anos. Sobre a vida de Nabuco nos primeiros anos da década de 1880, ver Angela Alonso, Joaquim Nabuco: os salões e as ruas. São Paulo: Companhia das Letras, 2007, cap. 3 "A experiência inglesa" e 4 "No olho do furacão".

316 Joaquim Nabuco ao barão de Penedo. Rio de Janeiro, 23/06/1884. Biblioteca Nacional. Arquivo Tobias Monteiro, 63,03,005 n 032, 2 doc., 5 p. O discurso de Saraiva, acima citado, encontra-se em AS. 
Conselho, que ia bem "pondo-se à frente do movimento emancipador". Cortejado por Saraiva e Dantas, que "vieram ver-me e tratam-me como um bom aliado", o abolicionista preparava-se para um grande combate: "Se o Imperador dissolver a Câmara com o Dantas entraremos numa fase agitada da revolução abolicionista. Ele quer pouco, é certo, mas o pouco em tais questões torna-se muito pela energia que é preciso empregar para consegui$10 " 317$

Dantas não queria tão pouco, como geralmente não quisera ao longo de sua vida política. Como observa Alonso, "sua singularidade eram pés nas duas canoas em que a política imperial se cindia, as instituições e o espaço público". Apoiador da reforma eleitoral, da autonomia provincial e do casamento civil, membro de sociedades libertadoras e "chefe que indicara Sátiro Dias para reconhecer a abolição no Ceará", o presidente do Conselho "sintonizava com o movimento abolicionista". ${ }^{318}$ Sua visita a Nabuco servira para sinalizar que trabalharia por uma candidatura viável que levasse o principal representante do abolicionismo militante na alta política nacional de volta ao Parlamento. Dantas sabia que precisaria de muito apoio para o sucesso de seu projeto. Apesar do conteúdo gradualista, que para alguns significava transigência para com os interesses dos grandes proprietários de escravos, havia razão para o apelo de suas disposições aos abolicionistas.

O projeto foi apresentado aos deputados no dia 15 de julho, por Rodolfo Dantas. ${ }^{319}$ Entre outras disposições, a proposta previa a emancipação automática de todos os escravos sexagenários, isto é, aqueles que atingissem 60 anos de idade poderiam abandonar seus senhores sem nenhum tipo de restrição ou indenização. Este foi um ponto relevante, de acordo com Joseli Mendonça, para a ampla rejeição do projeto Dantas. ${ }^{320}$ Segundo a autora, o discurso escravocrata naquele momento fiava-se fortemente na lei de 1871 . Inicialmente combatido pela grande lavoura e seus representantes, o Ventre Livre, frente às ameaças abolicionistas, acabou se tornando o escudo de tais setores, que se atinham na defesa do gradualismo e da indenização, previstos por aquela lei, para blindá-la como palavra final no processo de emancipação dos escravos. ${ }^{321}$ Diferentemente das leis antitráfico, que

09/06/1884, p. 24.

317 Joaquim Nabuco ao barão de Penedo. Rio de Janeiro, 23/06/1884. Biblioteca Nacional. Arquivo Tobias Monteiro, 63,03,005 nº 032, 2 doc., 5 p. 318 Cf. Angela Alonso, Flores, Votos e Balas, p. 221.

319 ACD. Sessão de 1884, tomo II, pp. 16-20. 320 Cf. Joseli Maria Nunes Mendonça, op. cit. 321 Ibid., pp. 119-128. 
legislaram sobre "proibição de aquisição de escravos 'vindouros' da África", e da lei de 1871, que "legislou sobre indivíduos ainda não nascidos", o projeto de libertação dos sexagenários significava a intervenção direta do Estado nas relações entre proprietários e suas propriedades. "Arrancando" os escravos de seus senhores, o projeto, se convertido em lei, significaria a deslegitimação do domínio senhorial, com consequências imprevisíveis para todo o sistema. ${ }^{322}$ Mais ainda, o projeto previa que os cativos libertados teriam poder de escolha sobre seu destino, isto é, caberia exclusivamente a eles a decisão sobre se manterem ou não na companhia de seus ex-senhores. Inaceitável para a grande lavoura, este grau de autonomia concedido ao liberto rompia com a lógica do gradualismo, que, reafirmando a suposta incapacidade do escravizado para o exercício da liberdade, tratava de "estabelecer um sistema de libertação que não rompesse o controle dos antigos senhores sobre os libertos". 323

Imediatamente após apresentação do projeto, o presidente da Câmara, o deputado liberal paulista Moreira de Barros, pediu demissão do cargo. A atitude do parlamentar era mais do que simbólica, significando uma cisão clara no partido. ${ }^{324}$ Devido à relevância do cargo de presidente da casa, como articulador político ${ }^{325}$ e principal mediador entre governo e deputados, um pedido de demissão significava impor ao gabinete uma questão de confiança. Assim, se a maioria dos parlamentares rejeitasse a demissão de Moreira de Barros, o governo seria colocado em uma posição insustentável, tendo duas opções: pedir demissão ou solicitar a dissolução da Câmara dos Deputados. Não sobrava ao gabinete, portanto, senão esperar que a maioria do plenário aceitasse o pedido do então presidente da Câmara.

Moreira de Barros justificou sua atitude relatando que, dias antes, após tomar conhecimento do artigo $1^{\circ}$ do projeto, ${ }^{326}$ já declarara ao presidente do Conselho que não poderia se manter no cargo, por não concordar com a libertação de escravos sem indenização. Dantas, no entanto, "exigira" que não se manifestasse nesse sentido até a

322 Ibid., pp. 256-257.

323 Ibid., p. 71.

324 ACD. $15 / 07 / 1884$, pp. $165-168$.

325 Há que se lembrar que cabia ao presidente da Câmara a expedição dos assuntos a serem tratados em plenário, ou seja, a redação da ordem do dia, fundamental para determinar a premência, ou não, de projetos e questões apresentadas.

326 Além de declarar livres ipso facto os escravos sexagenários, o artigo $1^{\circ}$ do projeto dispunha sobre a necessidade de realização de uma nova matrícula dos escravos do Império, a fixação dos valores dos cativos por faixa etária, bem como criava novo imposto como contribuição ao fundo de emancipação e localizava provincialmente a escravatura. ACD. Sessão de 1884, tomo II, pp. 16-18. 
apresentação do projeto na Câmara, o que Moreira de Barros acatou. ${ }^{327}$

As motivações de Moreira de Barros, no entanto, iam além de sua contrariedade com as disposições do artigo $1^{\circ}$ que, por sua vez, iam bastante além da libertação dos escravos sem indenização. O deputado afirmava ser-lhe "grato" que se apresentasse na Câmara as “ideias mais adiantadas para o debate, como meio de entregar a solução desta questão ao único poder competente neste país". Este, para o deputado, seria "o meio de mostrar que o movimento da rua não tinha razão de ser", compelindo os poderes públicos a empregar a "mais severa energia para reprimir os atos criminosos" daqueles que,

[...] levando o susto e provocando as cenas de sangue que temos presenciado no interior do país (apoiados e não apoiados), alarmam todos os interesses e ameaçam tantas existências (apoiados e não apoiados) e bem manifestar o seu desagrado àqueles que exploram este assunto como meio de adiantamento de carreira $(\mathrm{Oh}$ ! $o h !) .{ }^{328}$

Contudo, em vez de deixar ao Parlamento a iniciativa que lhe cabia de iniciar tal discussão, o ministério comprometia o Partido Liberal com uma bandeira que não era a sua, ${ }^{329}$ de modo que Dantas e seus colegas agiam de maneira injustificável ao obrigar parlamentares a se posicionarem acerca de uma questão sobre a qual os eleitores, quando lhes haviam conferido seus mandatos, não cogitavam. Uma vez que se colocava o projeto no terreno da confiança, e não como "programa para as próximas eleições”, Moreira de Barros se sentia obrigado a censurar o ministério.

Nesta primeira votação, o governo angariou uma pequena, mas significativa maioria. O próprio presidente demissionário da Câmara afirmou que lhe causara surpresa o apoio alcançado por Dantas: "não supunha que S. Ex. pudesse contar com mais de 30 adesões, e sua S. Ex. creio que já venceu esse número". ${ }^{330}$ Ainda que a demissão tenha sido aprovada por uma pequena margem de votos, 55 deputados e 52 contra, havia se alinhado com o ministério um número de representantes que ultrapassava bastante as projeções de Moreira de Barros. ${ }^{331}$ Vale destacar que, dentre aqueles que rejeitaram a demissão, estavam os deputados de oposição (conservadores) e alguns dos liberais dissidentes que, tempos antes, haviam se posicionado contrariamente ao deputado paulista em censura ao ministério

327 ACD. 15/07/1884, p. 165.

328 Ibid., p. 165.

329 Ibid., p. 166

330 Ibid., p. 166.

331 Ibid., pp. 170-171. 


\section{Lafaiete.}

A derrota da oposição não arrefeceu sua animosidade contra o ministério. Pelo contrário, dias depois estava montado o cenário para uma nova batalha. Entre seguidas tentativas de impor uma nova questão de confiança ao governo, o representante de Alagoas Lourenço Cavalcanti de Albuquerque, membro da nova dissidência do Partido Liberal formada a partir do pedido de demissão de Moreira de Barros, levou adiante o discurso do ex-presidente da câmara temporária. ${ }^{332}$ Declarando, como fizera o deputado paulista, ter aprovado, num primeiro momento, a iniciativa do governo de tomar em suas mãos a solução da questão servil, por lhe parecer "que este era o meio de levar a paz a todos os espíritos que se sentiam mais ou menos sobressaltados com essa propaganda artificial que se levantou nesta capital", Lourenço de Albuquerque afirmou não ter sido possível manter tal posição quando se tornaram evidentes as verdadeiras intenções de Dantas. "O honrado presidente do conselho", acusou o deputado alagoano, não chamara a si a questão "para tranquilizar os ânimos, para inspirar confiança ao país, mas para dar um passo tão adiantado como o poderiam desejar os propagandistas”. E completou, para não haver dúvidas sobre a verdadeira natureza do gabinete liderado por Dantas: "O que é o ministério 6 de junho? Não é outra coisa mais que o projeto abolicionista (Apoiados)". 333

Deste modo, a oposição sabia muito bem que o que desejava Dantas não era "pouco". Para além da libertação incondicional dos escravos sexagenários, havia questões de fundo que faziam do projeto ministerial um "projeto abolicionista". Como demonstra Angela Alonso, após as aflições causadas pelo plano de libertação incondicional de escravos idosos, o pesadelo dos oposicionistas continuava com as disposições concernentes à realização de nova matrícula da população escrava. O fato de que muitos senhores haviam, na matrícula realizada em 1872, após a aprovação da Lei do Ventre Livre, registrado seus escravos com idade acima da real, pretendendo burlar a lei de extinção do tráfico atlântico de 1831, significava que havia, em 1884, um contingente considerável de "sexagenários" em idade produtiva. Insistir na declaração fraudulenta poderia significar libertar tais escravos, enquanto admitir o "artifício" poderia "redundar em contestação legal do título de propriedade". ${ }^{334}$ Havia ainda um ataque econômico direto ao sistema escravista, com "incentivo à concentração de escravos no meio rural" e congelamento de seus preços por

332 ACD. 28/07/1884, pp. 356-357.

333 Ibid., p. 356.

334 Cf. Angela Alonso, Flores, Votos e Balas, p. 223. 
faixa etária, intervindo no mercado e facilitando a "estratégia dos abolicionistas de compra de alforrias". ${ }^{335}$ Nesse sentido, conclui a autora:

[...] Dantas apresentava feixe de medidas bem mais controversas que libertar idosos: cancelava títulos de propriedade de escravos de meia idade registrados como mais velhos; intervinha no mercado, fixando preços, taxando a posse de escravos e proibindo sua venda entre províncias; instituía plano piloto de pequenas propriedades; criava salário mínimo para libertos e punha prazo final à escravidão, sem indenização [...]. O Projeto 48 embutia modelo de nova sociedade pós escravidão, baseada em assalariamento do ex-escravo, imigração e difusão da pequena propriedade. Passaporte para o sonho de Rebouças, a 'democracia rural'. ${ }^{336}$

O presidente do Conselho apresentou um projeto que apelava aos abolicionistas; e ele bem sabia que precisaria de seu apoio. Apesar de não considerá-lo a solução ideal, membros do movimento passaram a defender de forma obstinada o gabinete Dantas. Acima de tudo, a esses abolicionistas importava o fato de que o projeto não era "outra coisa senão a conversão do partido liberal" aos princípios que proclamavam havia seis anos. ${ }^{337}$ Mas arregimentar sustentadores de todas as alas do Partido Liberal, garantindo um compromisso geral do partido com tais ideias, era fundamental. E o presidente do Conselho foi consideravelmente bem-sucedido em tal tarefa. Dissidentes e conservadores surpreenderam-se com o número de deputados que cerraram fileiras com o ministério. A Gazeta da Tarde não tardou na desforra:

Contados todos os votos de que possa dispor a conspiração antipatriótica, se reconhece que o ministério dispõe por seu lado de apoio decisivo.

São os próprios adversários que o confessam.

Da legião do Sr. Paulino de Souza partiu este grito: traga o governo o projeto sobre o elemento servil e verá que não conta vinte votos.

O projeto apareceu, e reuniu em torno de cinquenta e cinco votos, isto é, metade da nação representada na câmara. ${ }^{338}$

Somente o projeto de emancipação havia sido assinado por 28 deputados, além do

335 Ibid., p. 224.

336 Ibid., p. 225. A autora se refere ao art. $2^{\circ}$ do projeto que, entre outras disposições, planejava a criação de colônias agrícolas para libertos nas margens das estradas de ferro. Seu $\S 15$ dispunha: "Nos regulamentos das colônias de libertos se estabelecerão regras para a conversão gradual do foreiro ou rendeiro do Estado em proprietário dos lotes de terra que utilizar a título de arrendamento”. ACD. Sessão de 1884, tomo II, p. 20.

337 Joaquim Nabuco, "Conferencia a 22 de Junho de 1884”. Apud Robert Conrad, op. cit., p. 261.

338 Gazeta da Tarde. 17/07/1884, p. 1. Paulino de Souza era, então, líder dos conservadores na Câmara. 
filho do chefe do gabinete, Rodolfo Dantas, representante da Bahia. ${ }^{339}$ Na vitória alcançada quando da questão de confiança deflagrada pelo pedido de demissão de Moreira de Barros, o ministério viu tal número dobrar. Fundamentalmente, a base de apoio mais sólida a Dantas provinha de quatro províncias. Na Bahia, onde o próprio presidente do Conselho era "chefe e diretor da política provincial" 340 e cuja "assombrosa atividade", durante o decênio conservador de 1868 a 1878, havia transformado num dos principais redutos liberais, ${ }^{341}$ Dantas possuía fiel apoio de toda a bancada de seu partido. Assim, descontados dois deputados que, por serem ministros, não participavam de votações de confiança, ${ }^{342} \mathrm{o}$ governo obteve o restante dos oito votos dos liberais baianos. Do Maranhão, terra do ministro do Império, Franco de Sá, e do Piauí, terra do então visconde de Paranaguá, que passara a apoiar o gabinete e seu projeto, junto de seu genro, Franklin Dória, vieram nove votos no total, com ambas as bancadas liberais coesas. ${ }^{343}$ Do Rio Grande do Sul, que muitos indicavam estar prestes a ser emancipado, vinham cinco votos de uma bancada fiel ao emancipacionista Silveira Martins, que também apoiava Dantas naquele momento, além de um voto do conservador Severino Ribeiro. ${ }^{344}$ Bancadas liberais de outras províncias menores, por motivo de pouco interesse no trabalho escravo ou de política partidária, também davam seus votos unânimes ao gabinete.

Desse bloco de bancadas coesas, Dantas retirava cerca de trinta votos, mais da metade do total alcançado. $\mathrm{O}$ restante da bancada liberal se encontrava consideravelmente dividido, inclusive no caso das províncias centrais ainda não mencionadas. ${ }^{345}$ Alguns liberais que vinham de Minas Gerais, São Paulo, Rio de Janeiro e Pernambuco, todas com bancadas

339 Dos signatários, outros quatro eram baianos: Rui Barbosa, César Zama, Francisco Prisco de Souza Paraíso e Aristides de Souza Spinola; quatro eram do Maranhão: Sinval Odorico de Moura, Salustiano Ferreira de Morais Rego, José Viana Vaz e Antônio de Almeida Oliveira; três representavam o Piauí: Franklin Américo de Menezes Dória, Cândido Gil Castelo Branco e José Basson de Miranda Osório; havia três liberais do Rio Grande do Sul, Antônio Eleutério de Camargo, Antônio Antunes Ribas e José Francisco Diana, e um conservador daquela província, Severino Carneiro Ribeiro Monteiro; outros três liberais representavam Alagoas: Tomás do Bonfim Espíndola, Teófilo Fernandes dos Santos e Francisco Ildefonso Ribeiro de Menezes; dois eram mineiros: Eduardo Augusto Montandon e Silviano Brandão; dois representavam o Ceará: Tomás Pompeu de Souza Brasil e José Pompeu de Albuquerque Cavalcanti; havia ainda cinco províncias com um signatário cada, todos também liberais, Paraná, Amazonas, Rio Grande do Norte, Goiás e Pernambuco, representadas, respectivamente, por: Generoso Marques dos Santos, Adriano Xavier de Oliveira Pimentel, Amaro Carneiro Bezerra Cavalcanti, José Leopoldo de Bulhões Jardim e José Mariano Carneiro da Cunha. ACD. Sessão de 1884, tomo II, p. 20.

340 César Zama a José Antônio Saraiva, 23/05/1886. AIHGB. DL 274.49, doc. 5.

341 Cf. Tobias Monteiro, op. cit., pp. 39-40.

342 Eram eles Francisco Maria Sodré Pereira, que ocupava a pasta da Justiça, e Antônio Carneiro da Rocha, na Agricultura. Cf. Barão de Javari, op. cit., pp. 212-213.

343 ACD. 15/07/1884 e 28/07/1884.

344 Ibid.

345 Ibid. 
conservadoras significativas, se reuniam a representantes do Ceará, Alagoas e Sergipe na solidariedade ao ministério. Mas havia em tais províncias dissidências numericamente relevantes. ${ }^{346}$ A partir de tais informações, é possível realizar algumas considerações importantes.

É comum que a historiografia privilegie um corte de cunho regional (Norte-Sul) nas apreciações que faz da polarização entre escravistas e emancipacionistas (a que a historiografia faz também recorrente menção). Em tais divisões, destaca-se a ampla votação auferida por Dantas nas províncias onde a escravidão perdia força, especialmente as do Norte, bem como no Rio Grande do Sul. Do mesmo modo, a oposição a Dantas se concentraria especialmente nas províncias cafeeiras do Sul. ${ }^{347}$ Contudo, é possível, ao se observar mais de perto os dados fornecidos pela documentação, entrever que outros importantes fatores parecem ter influído nas atitudes dos parlamentares.

Nas votações de confiança pelas quais passou o ministério Dantas no ano de 1884, o número de liberais que votou contra o ministério nunca alcançou a margem de duas dezenas. ${ }^{348}$ Isto significa dizer que, dos cerca de setenta liberais que havia então na câmara temporária, ao menos cinquenta votaram consistentemente a favor do ministério Dantas. Os que se destacaram da maioria, ou seja, aqueles que compuseram a dissidência ao partido, representavam especialmente duas províncias: Minas Gerais e São Paulo. ${ }^{349}$ Além delas, Pernambuco, Paraíba, Alagoas, Sergipe e Rio de Janeiro tiveram também dissidentes em suas fileiras. ${ }^{350}$ Todas essas províncias contavam ainda com relevante representação conservadora. Rio de Janeiro e Pernambuco, que votaram consistentemente contra o gabinete, possuíam, particularmente, bancadas de maioria conservadora, mas os poucos liberais eleitos votaram majoritariamente pelo ministério. ${ }^{351} \mathrm{O}$ Pará, contando com

346 Barão de Javari, op. cit., pp. 373-379. ACD. Sessão de 1884, tomo II, pp. 23-24.

347 Ver, especialmente, Robert Conrad, op. cit., pp. 263-264.

348 ACD. 15/07/1884 e 28/07/1884.

349 De Minas, entre quatorze liberais eleitos, num universo de vinte deputados, sete votaram contra o ministério: Carlos Afonso de Assis Figueiredo, Barão da Contagem, Carlos Vaz de Melo, João Nogueira Penido, Joaquim Vieira de Andrade, Antônio Felício dos Santos, e Afonso Augusto Moreira Pena. De São Paulo, entre sete liberais eleitos, num universo de nove deputados, três se mostraram consistentemente contrários ao ministério: Antônio Moreira de Barros, Bento Francisco de Paula Souza e Francisco Antônio de Souza Queirós Filho. Cf. Barão de Javari, op. cit., pp. 376-378; ACD. Sessão de 1884.

350 ACD. Sessão de 1884, tomo II, p. 31.

351 Dos doze deputados que compunham a representação do Município Neutro e da província do Rio de Janeiro na $18^{a}$ legislatura, os conservadores, em número de nove, votaram consistentemente contra o ministério. Entre os três liberais que completavam a bancada provincial, apenas Elias Antônio de Morais, eleito um ano antes, após o falecimento de um deputado conservador, colocou-se contra o governo. Em Pernambuco, os oito conservadores, entre treze deputados, mantiveram-se consistentemente em oposição 
bancada unanimemente conservadora, votou, homogeneamente, contra o ministério. ${ }^{352} \mathrm{O}$ caso mais peculiar, como já acima mencionado, foi o do Ceará, província emancipada em que a bancada liberal manteve posição movediça, finalmente e decisivamente se voltando contra o ministério e seu "projeto abolicionista". ${ }^{353} \mathrm{Na}$ importantíssima província da Bahia, por sua vez, a divisão se deu totalmente em linhas partidárias, com os liberais votando unanimemente a favor do ministério e os conservadores, unanimemente contra. ${ }^{354}$

Nas províncias de São Paulo e Minas Gerais, onde as divisões do Partido Liberal foram notáveis desde a apresentação do projeto de 15 de julho, também não parece acertado ignorar as relações entre os deputados e seus distritos de origem. Se a eleição direta havia aproximado os candidatos de seus eleitores, a indignação demonstrada por Moreira de Barros, ao acusar Dantas de obrigar os deputados a votarem em um projeto que não constara de qualquer programa eleitoral, ${ }^{355}$ pode, ao menos até certo ponto, ser também compreendida nesses termos. Particularmente no caso do presidente demissionário da câmara baixa, seus eleitores pertenciam a uma região ainda muito ligada ao trabalho escravo: Moreira de Barros representava a tradicional zona cafeicultora do Vale do Paraíba, tendo seu círculo eleitoral como sede a cidade de Taubaté. ${ }^{356}$ No caso de Minas Gerais, por outro lado, enquanto Afonso Celso Jr., firme defensor do ministério, representava o $20^{\circ}$ distrito da província, que tinha sede em Grão-Mogol, no sertão mineiro, João Penido, dissidente dos mais obstinados, representava o $10^{\circ}$ distrito, com sede em Juiz de Fora, região importante e tradicional da cafeicultura mineira, fortemente ligada à escravidão. ${ }^{357}$

ao ministério Dantas. Dos cinco liberais, um votou contra o gabinete. Ibid., p. 31; Barão de Javari, op. cit., p. 374-376.

352 ACD. Sessão de 1884, tomo II, p. 31.

353 Da província emancipada, um conservador e três liberais votaram contra o ministério, enquanto dois conservadores e um liberal deram a ele seu voto de confiança. Um dos liberais que havia assinado o projeto emancipacionista de 15 de julho, José Pompeu, abandonou o ministério e absteve-se. ACD. Sessão de 1884, tomo II, pp. 23-24 e 31. Interessante é o fato de que os dois deputados conservadores que a província do Ceará enviara à Câmara, Antônio Pinto de Mendonça e Álvaro Caminha Tavares da Silva, apoiaram o ministério, justificando seu afastamento da direção de Paulino de Souza pelos interesses de sua província emancipada.

354 Dos quatorze representantes que possuía a Bahia na câmara temporária, apenas três votaram contra o ministério, todos conservadores. Além disso, dois liberais não puderam tomar parte nas votações por comporem o ministério. ACD. Sessão de 1884, pp. 23-24 e 31.

355 ACD. 15/07/1884, p. 166.

356 Para as divisões dos círculos eleitorais de São Paulo, realizada em 1881, ver: Gazeta de Notícias, 18/03/1881, p. 1 .

357 Obviamente, tais exemplos são apenas ilustrativos e têm como fim demonstrar as demandas complexas a que estavam submetidos os deputados após a reforma eleitoral de 1881. Não se pretende afirmar, portanto, que os interesses do distrito de origem fossem solitariamente decisivos nos posicionamentos de tais políticos, mas que estavam inseridos numa miríade de considerações e cálculos políticos que tais parlamentares precisavam realizar, junto a considerações de política provincial, partidária e nacional. Nesse sentido, parece sensato inferir que a influência de Martinho Campos, representante direto dos 
Levando em conta tais considerações, portanto, parece possível propor que o repúdio a Dantas e seu projeto se dava tanto em linhas provinciais e regionais (aquelas com maior interesse na manutenção do cativeiro), quanto em linhas político-partidárias, sendo que os dissidentes representavam províncias com bancadas liberais cindidas, muitas vezes por questões tão ligadas a interesses das elites locais e por disputas internas ao Partido Liberal, quanto a desacordos na política geral.

Apesar de numericamente reduzida, a dissidência liberal tornou-se extremamente ativa, e os conservadores assistiram calados enquanto as trocas de farpas entre seus adversários chegaram ao ápice naquele ano. No dia 28 de julho, a dissidência, já relativamente consolidada, retomou as investidas contra o gabinete. Da província emancipada do Ceará, como vimos, se bandearam definitivamente para a oposição três deputados liberais, alegando não praticar o governo, em sua província, política que lhes agradasse. ${ }^{358} \mathrm{O}$ primeiro ataque partiu do então dissidente cearense Leandro de Chaves e Melo Ratisbona, que solicitou o adiamento dos debates acerca das leis orçamentárias. ${ }^{359} \mathrm{O}$ deputado justificou seu requerimento alegando ser necessário verificar se o governo mantinha maioria na Câmara. A oposição deixava evidente que havia conseguido arregimentar mais parlamentares para seu lado, revertendo a pequena desvantagem da votação de 15 de julho. Dantas, no entanto, foi categórico: apresentassem os adversários moção que se referisse diretamente ao projeto emancipacionista. Do contrário, o governo não aceitaria questão de confiança:

Sr. presidente, nada de ilusões, nada de mistificações (apoiados da maioria). O momento é dos mais graves, é dos mais solenes para a vida de um parlamento, representante dos destinos de um grande povo, que se rege por leis onde estão consagrados os mais elevados princípios da liberdade.

De que se trata, Sr. presidente? O que se pretende com o requerimento de adiamento? Demorar a discussão da lei de orçamento, quando, como a câmara e o país sabem, esta lei não pode constituir questão de confiança (apoiados da maioria), quando a sua necessidade é de ordem tal que os mais intransigentes adversários até

interesses da Zona da Mata mineira e "escravocrata da gema", tinha grande impacto no equilíbrio partidário de sua província. Apesar de encontrar-se adoentado, o senador continuava sendo "uma das maiores e mais legítimas glórias do Império", segundo um de seus correligionários que, não obstante, encontrava-se em posição oposta a ele. A Gazeta da Tarde, por sua vez, reservava ao estadista mineiro uma qualificação menos elogiosa: "comadre da escravidão". Sobre a doença de Martinho Campos, que começara apoiando o ministério, mas se voltou contra ele após ficarem claras suas intenções quanto ao “elemento servil", ver: Angela Alonso, Flores, Votos e Balas, p. 227. Para o epíteto atribuído por Afonso Celso Jr., ver: ACD. 15/07/1884, p. 169.

358 Gazeta de Notícias. 29/07/1884, p. 1. José Pompeu, Rodrigues Júnior e Meton da Franca Alencar recusaram-se a apoiar o gabinete.

359 ACD. 28/07/1884, p. 353-354. 
hoje não negaram o seu voto a ela [...] visto que, como também se sabe, é impossível um governo regular administrar sem achar-se armado das leis de meios (apoiados $d a$ maioria). ${ }^{360}$

As tergiversações da oposição tinham um motivo evidente: "ela não pôde chegar a um acordo sobre uma moção de confiança" que tratasse do projeto de emancipação. ${ }^{361}$ Para indignação de seus adversários, Dantas apontava para as divisões intestinas no heterogêneo bloco oposicionista. Os conservadores, era verdade, se mostravam coesos e disciplinados pela "mão férrea" de Paulino de Souza, no Sul do país, "assistido por Andrade Figueira", ao mesmo tempo em que, ao Norte, João Alfredo e Cotegipe "faziam o serviço". ${ }^{362}$ Por outro lado, os dissidentes, como vimos, formavam um bloco heterogêneo e sem projeto comum. Afastados da maioria de seu partido, estavam tanto um Moreira de Barros, representante do Vale do Paraíba paulista, região onde os interesses dos proprietários de escravos eram decisivos, quanto os dissidentes do Ceará, representantes de uma província já emancipada, cujo ressentimento para com seus correligionários se dava por motivos que iam além da questão servil. Não é difícil perceber a dificuldade em se conciliar tais interesses em uma censura explícita ao projeto de emancipação. Os custos políticos de tal decisão variavam para cada deputado.

Se a oposição não conseguia acordo sobre a moção de desconfiança ao ministério, questionava o presidente do Conselho, por que não saía das trincheiras e priorizava o interesse público, auxiliando o governo a solucionar a questão do elemento servil? Querer salvar a escravidão, vaticinava Dantas, era uma "causa perdida": "E é querer dar vida ao cadáver pretender que uma ideia condenada, diante da qual os mesmos Srs. deputados da oposição fogem espavoridos, possa renascer, criar novas raízes no seio do povo e impor-se ao seu parlamento (muito bem, muito bem da maioria"). ${ }^{363}$

A firmeza do gabinete e os apelos de seu chefe não bastaram para que os opositores se decidissem a apresentar reprovação explícita ao projeto de emancipação. Lourenço de Albuquerque, representante de Alagoas, condenou veementemente a proximidade entre o governo e a agitação promovida pelo movimento abolicionista, afirmando que apresentaria uma moção cujo pensamento era a condenação das "ideias principais do projeto sobre o

360 Ibid., p. 354.

361 Ibid., p. 354.

362 Cf. Angela Alonso, Flores, Votos e Balas, p. 226.

363 ACD. $28 / 07 / 1884$, p. 356. 
elemento servil". No entanto, tal "pensamento" não estava explícito na moção, que condenava o governo por continuar na gestão dos negócios públicos sem o apoio da Câmara dos Deputados. ${ }^{364}$ Exasperado, Afonso Celso Jr. protestou: "Venha a moção negra, sejam francos". Foi o dissidente mineiro João Nogueira Penido, para a surpresa e indignação geral dos conservadores, quem apresentou, em termos inquestionáveis, a moção derradeira: "A câmara, reprovando o projeto do governo sobre o elemento servil, nega-lhe sua confiança". "Espumando", por se verem obrigados a votar sobre o projeto do elemento servil, os "escravagistas" vituperaram a ousadia de Penido em contrariar seus planos. ${ }^{365}$ Porém, o dique fora rompido.

Rui Barbosa se aproveitou do alvoroço em que se encontravam os adversários para, de uma vez por todas, colocá-los contra a parede. ${ }^{366}$ A "luta de emboscadas" que a oposição travava contra o gabinete, não assumindo sua hostilidade ao projeto, ilustrava, para o representante da Bahia, a pusilanimidade de quem conhecia a própria fraqueza. O silêncio até então mantido pelos conservadores era indicador de que não estavam em harmonia, como se propalava; aquela "mudez sistemática" era antes temor frente a uma ideia que rasgava "profundamente as suas fileiras", e para a qual havia duas soluções: "obrigar muitos dos seus combatentes a se afastarem dos seus amigos ou a fazerem holocausto de sua consciência nas aras do interesse do partido". Escondidos atrás de uma dissidência que mantinha uma atitude de "subterfúgio sistemático" perante a Câmara, vaticinou o liberal baiano, os conservadores desejavam sepultar o projeto emancipacionista antes mesmo que a representação nacional pudesse discuti-lo. Sabiam que, do contrário, não seria possível manter sua unidade. O Partido Liberal, por seu lado, já havia se convencido da inevitabilidade da emancipação. Tentar abafar a "solução liberal do problema" teria, alertou o orador, a consequência de precipitar a radicalização da questão que avassalava espíritos e consciências. O abolicionismo que então grassava, "desinteressado" e "generoso", não carregava a "bandeira vermelha da comuna", como dias antes acusara Moreira de Barros, mas se traído e inflamado pelos subterfúgios de seus inimigos, assumiria "sua expressão mais absoluta, mais sombria, mais devastadora". Seria este o abolicionismo provocado pela "reação", que a oposição então representava, "em ódio à experiência, à humanidade, ao futuro". Rui Barbosa foi veemente em conclamar todos a

364 Ibid., p. 357.

365 Gazeta da Tarde. 29/07/1884, p. 1.

366 ACD. 28/07/1884, pp. 357-360. 
assumirem suas posições:

[...] inspire-se cada um na sua discrição e no seu patriotismo. Acompanhem os nobres deputados, se o quiserem, as bandeiras negras do escravismo intransigente $(O h$ ! oh! reclamações, sussurro e trocam-se muitos apartes; o Sr. Presidente reclama atenção).

Acompanhem os nobres deputados, se quiserem, as bandeiras negras do escravismo intransigente. Mas muito pouco enxergará quem não perceber que é uma imprudência fatal ao espírito de transação (muito bem, muito bem); que deste modo não honram as aspirações da pátria, não obedecem a algum programa de partido, não beneficiam sequer os interesses dessa classe que tão falazmente se inculcam intérpretes e defensores. ${ }^{367}$

Parece não ter sido possível, aos adversários, permanecer incólumes às palavras demolidoras do afilhado do presidente do Conselho. Francisco Belisário e Moreira de Barros tentaram, ainda mais uma vez, esquivar, da "moção negra", a oposição, solicitando que às moções anteriormente apresentadas fosse dada prioridade no plenário. ${ }^{368} \mathrm{O}$ novo presidente da Câmara, Manuel Alves de Araújo, aliado de Dantas, não acatou os pedidos dos deputados, e a moção Penido foi posta em votação.

O ministério foi derrotado por uma diferença de sete votos, 59 a $52 .{ }^{369}$ A bancada liberal do Ceará votou em peso contra o gabinete e pendeu a balança para a oposição. Frente à ampla mobilização popular favorável ao ministério, que se assistia na Corte, cabia a um homem a palavra final sobre manter ou não Dantas à frente dos negócios públicos: "Sua Majestade que medite", recomendou a principal folha abolicionista da capital. ${ }^{370}$

No dia seguinte, reuniram-se os conselheiros de Estado para dar parecer sobre o impasse resultante da derrota ministerial no Parlamento. ${ }^{371}$ Como era de praxe em tais casos, o presidente do Conselho foi o primeiro a se pronunciar. Dantas defendeu a dissolução da Câmara dos Deputados, justificando que o ministério tivera o apoio da maioria até a apresentação do projeto sobre o elemento servil. Após o pedido de demissão de Moreira de Barros, o governo assistira, no entanto, ao encolhimento de sua base de apoio, ainda contando, porém, com uma pequena maioria. A partir de então, segundo o presidente do Conselho, a oposição passou a se utilizar de todos os expedientes possíveis para atacar o gabinete sem explicitar a causa maior de tal animosidade: o projeto

367 Ibid., p. 360.

368 Ibid., pp. 361-362.

369 Ibid., pp. 362-363.

370 Gazeta da Tarde, 29/07/1884, p. 1.

371 Atas do Conselho de Estado Pleno. Terceiro Conselho de Estado. Sessão de 29/07/1884. 
apresentado em 15 de julho. Não podendo o governo aceitar questão de confiança em outros termos, pois "o projeto era forçosamente o eixo em torno do qual devia girar o apoio ou a oposição da Câmara”, o ministério resistiu a todas as investidas dos adversários coligados, até que a moção Penido fosse apresentada. A derrota do governo na votação, no entanto, não demonstrava, segundo o presidente do gabinete, o panorama completo da câmara temporária. Três ministros deputados, tendo que passar por novo escrutínio após sua nomeação, haviam sido reeleitos, e era possível que o quarto também o fosse. Se se incluísse ainda os votos do novo presidente da Câmara, simpático ao ministério, e de um dos signatários do projeto que havia faltado à sessão, ${ }^{372 ~ " r e u n i r i a ~ o ~ g o v e r n o ~ o ~ a p o i o ~ d e ~} 58$ contra 59 membros daquela Câmara". Por tal motivo, era "manifesto", alegava Dantas, que, "numa questão capital para o país, como a do elemento servil, essa diferença de uma unidade não resolve o litígio". A própria recusa da oposição em discutir o projeto, por outro lado, demonstrava que seus membros não desejavam "esclarecer o país". Carecia a nação, portanto, “de intervir, pelo órgão de novos representantes, já que a maioria dos atuais recusa-se a encarar o problema". ${ }^{373}$

O contra-ataque dos adversários veio logo em seguida. Paulino de Souza rejeitou com veemência a perspectiva de dissolução da Câmara. Se o Imperador consentisse na dissolução, advertiu o conservador fluminense, corria o risco de "desvirtuar a intervenção moderadora da Constituição em meio de impulsão para a efetividade de intuitos, cuja promoção e responsabilidade devem exclusivamente pertencer à representação nacional e ao ministério por ela apoiado". 374

Em nome de um ministério que "açodava" a questão do elemento servil em projeto de partido e, cujo chefe, impunha ao Parlamento condições inaceitáveis, a Coroa não podia se arriscar a colocar o país em uma situação de virtual "ditadura financeira", o que ocorreria caso o decreto de dissolução fosse concedido antes da votação das leis orçamentárias pela câmara temporária. Seria uma chantagem à representação nacional, obrigada a conceder meios de governo a um ministério em que não confiava, com a alternativa de paralisar a administração do país. Consentindo nisto, a Câmara daria, na prática, seu "assentimento à aniquilação da influência parlamentar na presença de uma questão que se quer adiantar forçosamente" e que ameaçava graves interesses da sociedade. Seria, em outras palavras,

372 O presidente do Conselho se referia ao deputado cearense José Pompeu, omitindo oportunamente que este se havia "bandeado para a oposição", como noticiou a Gazeta de Notícias. 29/07/1884, p. 1.

373 Atas do Conselho de Estado Pleno. Terceiro Conselho de Estado. Sessão de 29/07/1884. 374 Ibid. 
uma demonstração de fraqueza "diante da grita leviana dos propagandistas irrefletidos da abolição do elemento servil". As nefastas consequências eram evidentes, alertava Paulino:

[...] a dissolução da Câmara dos Deputados, nas condições expostas, parecerá significar que o projeto de reforma do elemento servil é por esse dito reputado de tal modo urgente, que pode importar o caso mais grave de salvação pública, capaz de preterir o andamento regular da forma de governo e deslocar as órbitas constitucionais dos poderes políticos. ${ }^{375}$

Diante de tantas ameaças aos "interesses ordeiros" da sociedade, parecia, ao eminente conservador, que o governo procurava apoio em outro lugar. Mas seria a propaganda abolicionista, interrogou ironicamente o conselheiro fluminense, elemento estável o bastante para ter assento no governo do país? A resposta era obviamente negativa. Urgia, então, que se organizasse um novo gabinete que "tranquilize os espíritos e garanta a paz pública". ${ }^{376}$

Mais sete conselheiros de Estado votaram, como Paulino de Souza, contra a dissolução da Câmara dos Deputados. Outro conservador fluminense colocou a questão em termos menos drásticos, porém mais cristalinos que seu comprovinciano. Jerônimo José Teixeira Júnior alegou que a contrariedade da Câmara não era dirigida à iniciativa louvável de se promover uma reforma servil, mas ao procedimento que o ministério adotava para sua consecução. A questão de confiança só havia se dado nos termos da questão servil graças à intransigência do governo em enquadrá-la nesses termos. Se a Coroa consentisse no alvitre de "consultar diretamente a nação sobre o aludido projeto", arriscava-se a enveredar numa senda perigosa de politização de uma questão eminentemente social. Era de bom alvitre, portanto, que se esperasse pela organização de um novo ministério que, "menos intransigente à questão da reforma do estado servil", não a transformasse em "questão política", podendo assim ter sucesso em conseguir a adoção da "maior parte das providências indicadas no aludido projeto, com grande vantagem para a causa pública e maior proveito para todos os interesses aliados a este importante assunto". O outro caminho significaria o inconveniente de uma administração "ditatorial" no que se referia à questão financeira, e no grande perigo de se tornar "instrumento de política, e quiçá bandeira de agitação" um assunto que necessitava do "concurso de todos os partidos". 377

375 Ibid.

376 Ibid

377 Ibid. 
A diferença de ênfase nos pareceres de Paulino e Teixeira Júnior não era um problema menor. Ambos já haviam se enfrentado na renhida batalha pela Lei do Ventre Livre. O primeiro fora líder da dissidência conservadora, ferozmente hostil ao ministério Rio Branco; o segundo, genro do marquês de Paraná, fora, com João Alfredo Correia de Oliveira, um dos principais sustentadores da inciativa emancipacionista de $1871 .^{378}$ "Politizar" a questão servil para esses conservadores era gravíssimo, pois, transformada em bandeira político-eleitoral, diminuíam-se as possibilidades de se alcançar um consenso em torno de sua resolução e de se prolongar a frágil e recente harmonia que se testemunhava nas fileiras do partido. A clivagem, no entanto, estava implícita e se tornaria evidente nos meses seguintes: o Partido Conservador dividia-se entre aqueles que aceitavam o adiantamento da emancipação e aqueles que rejeitavam qualquer sinalização nesse sentido. ${ }^{379}$ Inaceitável era para todos eles, por outro lado, a intimidade do ministério com a "propaganda anárquica" e o conteúdo "abolicionista" de seu projeto.

Os liberais se mostravam claramente divididos. Sinimbu e Afonso Celso mantinham sua animadversão a Dantas. Dissolver a Câmara seria entregar o país à "luta das paixões mais temerosas que a política", advertiu o senador mineiro. Ao tirar o processo de emancipação dos termos gradualistas e indenizatórios da lei de 1871, que, admitia Afonso Celso, precisava de ajustes que a tornassem mais eficiente, o governo adotava uma postura de intransigência para com a Câmara dos Deputados, enquanto transigia com o movimento abolicionista; "pleitear-se uma eleição em nome da ideia emancipadora” significava, portanto, provocar a "confusão dos partidos. ${ }^{380}$ Para Sinimbu, por sua vez, a postura do governo demonstrava temeridade, enquanto a Câmara se mostrava prudente em resistir às investidas autoritárias do presidente do Conselho e seus colegas:

Com menos prudência houve-se o ministério suscitando em período adiantado da última legislatura a momentosa questão do elemento servil com a solene declaração de não admitir modificações nos pontos capitais do respectivo projeto, e fazendo, não sei se calculadamente, insinuações mui transparentes sobre a origem da projetada reforma. ${ }^{381}$

Temerária, a reforma, de "origem duvidosa", traduzia a imprudência do ministério, ao

378 Cf. Jeffrey D. Needell, The party of order, cap. 7 "The defeat of the party".

379 Tratar-se-á de forma mais detalhada de tais divisões nas seções seguintes do presente capítulo, bem como no capítulo 3 desta dissertação.

380 Atas do Conselho de Estado Pleno. Terceiro Conselho de Estado. Sessão de 29/07/1884.

381 Ibid. 
não reconhecer a necessidade de que uma questão de tamanha gravidade fosse resolvida "por meio de transação entre opiniões extremas [...] e com assentimento dos partidos constitucionais". ${ }^{382}$ Alentando "as perigosas exigências do abolicionismo impaciente e radical”, constituindo-o em "permanente ameaça à ordem pública e às classes produtoras", o gabinete havia passado por cima de "acertadas medidas, que facilmente alcançaria da Câmara dos Senhores Deputados", entre elas "o aumento do fundo de emancipação e a localização da escravatura". Em tal contexto, se fosse concedida a dissolução, seria de se esperar que o ministério procurasse "pontos de apoio onde quer que possa encontrá-los", ocasionando eleições que seriam feitas "sob o influxo de um pensamento reacionário e perturbador", 383

De que forma poderia, no entanto, interrogava o liberal paulista Martim Francisco Ribeiro de Andrada, uma Câmara dos Deputados - dividida em grupos que modificavam "as suas opiniões quase que semanalmente e muitas vezes ao sabor de interesses exclusivamente locais ou de distrito" - apresentar uma solução ao "problema cuja discussão evita"? A dissolução garantiria que o país saísse do impasse sobre como proceder à "extinção gradual da escravidão". ${ }^{384}$ Acima de qualquer dúvida, contudo, estava a percepção de que conservadores e dissidentes, dadas suas diferenças, não tinham condições de sustentar um governo de coalizão.

No mesmo sentido, o visconde de Paranaguá se pronunciou em favor do ministério, destacando a urgência de se tratar da extinção do elemento servil, majoritariamente apoiada pelos brasileiros:

Não há negar que a causa da emancipação é hoje o desideratum da grande maioria do país, quando de seu triunfo estão dependentes não só o progresso e a prosperidade do Império, como a paz e a tranquilidade pública. O Amazonas e o Ceará não têm mais escravos, o Piauí já conseguiu libertar um município, o Rio Grande do Sul prepara-se para em tão pouco tempo chegar ao mesmo resultado; nas demais províncias o movimento emancipador acentua-se e acelera-se cada vez mais; na Corte a opinião quase unânime é a seu favor; a imprensa toda, com raríssima exceção, o apoia e fomenta; numerosas associações dele fazem o seu objeto; todas as classes inteligentes o aplaudem e favorecem; não há quem francamente ouse combatê-lo; é, em uma palavra, uma aspiração nacional. ${ }^{385}$

Olhando para a opinião pública, para a "propaganda irrefletida", para os movimentos 
populares, um setor do Partido Liberal, que se mostrava crescentemente influente, aceitava a ruptura do monopólio decisório parlamentar sobre o processo de emancipação e apoiava que os cidadãos do Império pudessem intervir na resolução da grave "questão servil". Comprometendo definitivamente o Partido Liberal, para desespero de alguns de seus membros mais recalcitrantes, com os "princípios nacionais" que os abolicionistas proclamavam havia anos, ${ }^{386}$ aqueles homens tomavam uma decisão política de longo alcance, que, é verdade, lhes havia sido também imposta pelo recrudescimento das mobilizações sociais externas aos salões da alta política e às possibilidades encetadas pelo novo sistema eleitoral. A "aliança gabinete-movimento abolicionista" 387 expressava também uma aliança entre o abolicionismo militante e alas cada vez mais significativas do Partido Liberal. Não obstante as acusações de "politização" de um tema eminentemente "social”, esses liberais não recuavam em transformar as eleições (que seriam realizadas mediante a possível dissolução da Câmara, a ser concedida nos termos do impasse frente à “questão servil") em um plebiscito sobre o projeto "abolicionista" apresentado pelo filho do presidente do Conselho e formulado por Rui Barbosa. Paranaguá defendia tal medida como a única capaz de restabelecer a confiança do povo nos poderes públicos e na sua capacidade de dirigir prudentemente a "melindrosa questão", em um momento em que as eleições eram realizadas de forma mais autêntica do que jamais haviam sido: "[a] Câmara divorciou-se da opinião nacional, e o governo não compreenderia sua missão, se não apelasse para o juízo soberano do país". ${ }^{388}$

Para horror dos conservadores, o Imperador "meditou", como recomendara a Gazeta da Tarde, e concedeu a dissolução. As indicações de que o faria já haviam sido dadas pela imprensa da Corte mesmo antes de organizado o gabinete. Após as reuniões com Saraiva, Afonso Celso, Sinimbu e Dantas, no início do mês de junho, antes mesmo de se ter certeza de que seria este último a liderar a nova composição ministerial, não restava dúvida: "todos os cavalheiros foram da opinião que a situação liberal não podia permanecer no poder, sem o governo ter a garantia da dissolução, caso encontrasse resistência na câmara". ${ }^{389}$ Opinião honesta que favoreceu uns mais do que outros. Aí parece se encontrar, ainda, um dos motivos para a resistência da oposição conservadora em apresentar moção de desconfiança que claramente citasse sua reprovação à reforma servil. Se o Poder Moderador consentisse

386 Joaquim Nabuco, “Conferencia a 22 de Junho de 1884”. Apud Robert Conrad, op. cit., p. 261. 387 Expressão frequentemente utilizada por Angela Alonso, Flores, Votos e Balas. 388 Atas do Conselho de Estado Pleno. Terceiro Conselho de Estado. Sessão de 29/07/1884. 389 Gazeta de Notícias. 05/06/1884, p. 1. 
em dissolver a Câmara nesses termos, colocaria em xeque sua própria neutralidade, comprometendo-se de forma explícita com a "solução liberal" para o problema e deixando claro ao país que não era mais possível sufocar a questão servil. Se, no entanto, a moção fosse apresentada em termos genéricos, a Coroa teria liberdade de rejeitar a dissolução da Câmara, obrigando o gabinete a demitir-se, já que o compromisso contraído nas conversas com o presidente do Conselho circundava apenas o projeto de emancipação.

Entre a cruz e a espada, os conservadores romperam o silêncio no Parlamento. Domingos de Andrade Figueira declarou-se incrédulo quanto à promessa de dissolução feita pelo monarca, e sugeriu que as consequências de uma recusa em votar as leis orçamentárias seriam menos graves do que permitir que o ministério se mantivesse à frente dos negócios públicos, dando seguimento a seus planos. Era um dilema nefasto:

Se o ministério obtiver a lei de meios, ficará dotado dos recursos indispensáveis para viver, a dissolução da câmara não terá outro alcance senão colocar a questão do elemento servil como pomo de discórdia, como campo, como bandeira, em torno da qual as próximas eleições se deverão verificar no Império.

O governo poderá ter interesse em colocar assim as eleições, que deviam primar pela moderação, pela cordura, pela paz dos cidadãos interessados no jogo do regime representativo, em um campo inteiramente neutral e pacífico; poderá isto convir ao espírito de propaganda, de que o mesmo ministério declarou-se chefe.

O orador não compreende, porém, que a oposição possa e deva com o seu voto concorrer para semelhante resultado, que pode estar nas vistas do governo, mas que seguramente não está nas vistas daqueles que o derrotaram a propósito dessa mesma questão. ${ }^{390}$

Dantas redarguiu que os ataques da oposição não mudavam a situação de fundo: o povo apreciava o governo. Havia uma coisa, asseverou o presidente do Conselho, que nenhum poder humano jamais conseguiria: "que um povo aplauda um governo quando o julga mau”. Andrade Figueira não tardou em contestar: “o povo não dá vaias, não faz estes aplausos; o povo não se ocupa disto". Dantas rebateu e César Zama declarou, recebendo o aplauso de seus companheiros: "nós temos muita honra em ser povo nesta ideia". A troca de apartes prosseguiu até que Francisco Belisário interveio: "V. Ex. Pensa que os aplausos são ao projeto? É à ideia final. Para esses que aplaudem V. Ex. o projeto em si é muito insignificante". ${ }^{391}$ Paulino de Souza, por sua vez, afirmou que, por terem os conservadores, diferentemente do gabinete e seus apoiadores, apreço às instituições, votariam pela aprovação do orçamento.

390 ACD. 30/07/1884, p. 372.

391 Ibid., pp. 380-381. 
No mesmo sentido se pronunciou Moreira de Barros, líder da dissidência liberal, declarando não ser favorável a negar-se lei de meios ao governo, já que a dissolução da Câmara havia sido concedida e a consequência da dissolução sem aprovação do orçamento seria uma situação imprópria, para dizer o mínimo, ao sistema constitucional. Contudo, o deputado paulista não deixou de fazer mais acusações ao ministério, afirmando que Dantas contava com um certo temor ingênuo do monarca, que considerava o movimento que se agitava no país genuíno e potencialmente perigoso à ordem pública. Segundo Moreira de Barros, tal movimento era puramente artificial, nada tendo a ver com o pacífico povo brasileiro, devendo, portanto, ser desmascarado. ${ }^{392}$

Entre as trocas de farpas e as acusações ao ministério, Ferreira Viana levantou-se para denunciar o que asseverou ser mais um estelionato político praticado pelo "poder irresponsável". ${ }^{393}$ Objetivando deslegitimar a decisão da Coroa em conceder a dissolução da Câmara ao ministério sem a prévia votação das leis orçamentárias, o conservador fluminense colocou em questão a própria natureza do sistema representativo imperial, constantemente deturpado e corrompido, acusou Ferreira Viana, pelo "príncipe conspirador". Sua crítica ao ministério concentrou-se na iniciativa de levantar uma dupla bandeira - política e social - de caráter inquestionavelmente "incendiário", ameaçando, sob os auspícios do "César caricato", os interesses estáveis da sociedade, aqueles ligados à grande propriedade. Devido à constante intervenção do quarto poder na vida da nação, os partidos, que deveriam estar baseados em tais interesses, eram a única trincheira capaz de defendê-los do "despotismo", protegendo o que havia de liberdade constitucional. Assim sendo, os partidos jamais poderiam se basear em questões sociais e transitórias, como aquelas que defendiam os "agitadores" a quem o ministério tanto fazia questão de legitimar e afagar. Deviam, pelo contrário, encontrar meios de se organizar de forma mais sólida e estável, com chefes claramente identificáveis e munidos de ampla autoridade. As consequências da politização e partidarização da questão servil, advertiu então o orador, seriam profundamente derrisórias ao regime, pois significariam a invasão de elementos de agitação no debate político entre os partidos, deslocando-os de questões de fundo relativas ao bem-estar do Império para um tema condenado pelo tempo ao desaparecimento, devendo, portanto, ser solucionado pelo consenso das forças políticas legitimamente representadas no Parlamento, em um ambiente de tranquilidade e segurança àqueles que 
mais contribuíam à fortuna pública.

O discurso de Ferreira Viana remetia àquele contido na obra de seu correligionário e comprovinciano, Francisco Belisário Soares de Souza, sobre a questão eleitoral. ${ }^{394}$ Em um momento no qual os interesses representados por sua ala do Partido Conservador se encontravam ameaçados por dissensos internos e pressões externas, envolvia-se todo o regime numa crítica impiedosa às suas instituições e ao chefe do Estado. Nacionalizando a lavoura como alicerce sobre a qual se assentava a estabilidade do regime, acusavam os projetos, que levavam em conta outros interesses, de levianos e ilegítimos, patrocinados por um poder não apenas irresponsável, como também “conspirador". Apenas um projeto que levasse em conta o protagonismo absoluto da grande propriedade agrícola nos destinos da nação poderia se justificar. Nesse sentido, segundo Ferreira Viana, ao reconhecer a existência de outros interesses e envolvê-los no jogo político-partidário, o ministério abandonava seu papel de governo da nação, encarnada na grande lavoura, para tornar-se governo de um pequeno número de "incendiários", de modo algum representativos dos reais desígnios do país. À Coroa, principal alvo das ácidas críticas do grupo político a que pertenciam Ferreira Viana e Belisário no início da década de 1870, unia-se agora a "propaganda anárquica" das ruas que, num misto de incredulidade e temor, tentavam a todo custo deslegitimar como atores políticos a serem levados em consideração.

Se o deputado conservador pelo Rio de Janeiro enxergava a questão por um prisma próprio de sua posição político-partidária, havia em suas palavras uma percepção aguda dos acontecimentos. A opção por Dantas fora uma escolha, se não inevitável, evidente, para dar uma resposta à crescente agitação política extraparlamentar, num momento de conflagração social intensa à qual as instituições do país não podiam se dar ao luxo de permanecer indiferentes. Para Dantas (e muitos de seus aliados), como homem de Estado historicamente simpático e ligado a movimentos políticos que ultrapassavam as fronteiras tradicionais da política imperial, o Partido Liberal tinha a obrigação de se apresentar como representante de tais anseios, mantendo-os, na medida do possível, dentro da ordem, o que significava fazer concessões e enredá-los no processo político formal. A estratégia fora moldada também pela percepção das dissensões internas ao Partido Liberal, agravadas após a instauração das eleições diretas e a apresentação de um projeto emancipacionista mais avançado do que muitos esperavam, e da consequente insegurança do gabinete e da própria situação. Encontrar uma base de apoio alternativa seria possivelmente uma 
quimera em outros tempos e sob a liderança de um chefe de governo diferente; mas, numa conjuntura, em que o movimento abolicionista atingia um ápice organizacional e já havia experimentado firme e bem-sucedida aliança com o poder público, como no caso da libertação do Ceará, tal objetivo encontrava-se entre as opções políticas disponíveis. O fato de possuir modesta, mas combativa, base parlamentar, unido à proximidade do presidente do Conselho com figuras destacadas do movimento, tornava a aproximação ainda mais palpável. Longe de escapar aos contemporâneos, essa "aliança gabinete-movimento", como a chama Angela Alonso, ${ }^{395}$ acabou por definir não apenas a política do ministério Dantas ao longo de grande parte de seus onze meses de existência, como também estabeleceu o horizonte retórico e estratégico de seus adversários, delimitando o campo de luta política daquele momento. Mais do que isso, os surpreendentes acontecimentos ajudaram a redesenhar a própria lógica interna dos dois grandes partidos monárquicos, reabrindo velhas fissuras, criando outras novas e iniciando um deslocamento das esferas discursivas e programáticas até então vigentes, bem como uma redefinição das lutas políticas entre eles.

Nabuco não havia exagerado, portanto, quando afirmara que, se o monarca dissolvesse a Câmara dos Deputados com Dantas no governo, o país "entraria numa fase agitada da revolução abolicionista". ${ }^{396} \mathrm{O}$ "pouco" que queria o presidente do Conselho tornou-se muito pelo que foi preciso "empregar para consegui-lo".

\section{2 - Auge e queda do ministério Dantas (1885)}

Enquanto os partidos se arregimentavam para as eleições, os conservadores se reuniram, num banquete, para comemorar o aniversário da libertação do ventre, transformada em lei no dia 28 de setembro de 1871. Presidindo o evento, o barão de Cotegipe tinha a seu lado João Alfredo Correia de Oliveira. Paulino de Souza e seu primo, Francisco Belisário, por sua vez, não compareceram para assistir ao correligionário baiano reivindicar ao Partido Conservador as glórias da libertação de milhares de escravizados ao longo daqueles treze anos, e nem para secundá-lo em sua observação acerca do quanto se podia conseguir "com a fiel execução da mencionada lei e criteriosas medidas

395 Cf. Angela Alonso, Flores, Votos e Balas.

396 Joaquim Nabuco ao barão de Penedo, Rio de Janeiro, 23/06/1884. Biblioteca Nacional. Arquivo Tobias Monteiro, 63,03,005 nº 032, 2 doc., 5 p. 
complementares". Neste sentido, concluiu Cotegipe seu discurso na ocasião, afirmando que "o partido conservador deve, quer e pode proceder com a sua natural prudência". 397

O "deve, quer e pode" de Cotegipe ganharia, gradativamente, caráter fortemente explosivo nas lutas políticas dos meses seguintes. No mesmo banquete, o conselheiro Teodoro Silva, conservador de Pernambuco, declarou não "aconselhar a resistência" à emancipação:

Pelo contrário, entendo que não se pode parar, nem resistir; cumpre, sim, encaminhar a fixação dos termos do estado servil, conciliando o direito de propriedade com as possíveis aspirações libertadoras. O golfo não é tão profundo, que não se possa unir uma à outra margem. ${ }^{398}$

João Alfredo, por sua vez, comemorou a declaração feita pelo "pontífice da grei conservadora [...], de que esta deve, quer e pode resolver a questão do elemento servil", congratulou-se com seus correligionários e brindou à Princesa Imperial, por ter referendado, na condição de regente do Império, a "lei áurea", como então denominou a Lei do Ventre Livre. ${ }^{399}$ A declaração de Cotegipe criou uma nova situação política no Partido Conservador, sendo seu significado amplamente discutido pela imprensa da Corte nos meses seguintes. Seu principal efeito foi indicar que setores do Partido Conservador estavam preparados para realizar certas concessões no que dizia respeito à emancipação, desejando que o partido guiasse, ou ao menos interviesse ativamente num processo que ganhava radicalidade, o que uma abordagem intransigente só tenderia a piorar. A herança da lei de 1871, para tais homens de estado, se devia ser respeitada, deveria também guiar o caminho para novas medidas que adiantassem a extinção do cativeiro sem comprometer a lógica da gradualidade e da indenização.

Se parte importante do Partido Conservador passava a indicar estar disposta a, pragmaticamente, comprometer-se com uma agenda que, não rejeitando o adiantamento da emancipação, fosse capaz de contrabalançar o radicalismo dos liberais alinhados com o ministério Dantas, outros expunham suas imensas frustrações, acumuladas nos percalços da resistência. Meses depois do banquete conservador registrado pelo Brazil, já em meio ao calor do pleito eleitoral, seu diretor, Francisco Belisário, anunciava que deixaria a redação da folha. Órgão do partido na Corte, o jornal havia se tornado uma fonte de

397 Resumo das falas realizadas no banquete encontra-se em Brazil. 29/09/1884, p. 1. 398 Ibid., p. 1. 399 Ibid., p. 1. 
desgostos para Belisário, que expressava a seu primo uma grande decepção com a política, que não lhe permitia lá continuar. Confidenciando suas frustrações a Paulino de Souza, em meio a temores de que o resultado das eleições fosse negativo ao partido da ordem, Belisário ecoou Ferreira Viana e seu discurso acusatório acima mencionado: ${ }^{400}$

[...] para mim é impossível a monarquia constitucional. A comédia tem durado muitos anos e não é possível prosseguir mais com o consentimento e aprovação daqueles que nela não acreditam.

A esperança que eu depositava no resultado da eleição desapareceu. O Imperador quer e está acabado. Dantas faz tudo a um tempo - aprovação de seu projeto servil e a desmoralização da eleição. Nossos pais supuseram que se guardaria a ordem constitucional transigindo com o Imperador, eis o resultado final de tantas esperanças - a maior indignidade imaginável no poder. ${ }^{401}$

A animosidade dos conservadores em relação ao governo realmente deve ter crescido ao longo da campanha eleitoral de fins de 1884. Como demonstra Angela Alonso, enquanto o ministério enfrentava os impasses no Parlamento, "o movimento [abolicionista] orquestrou avalanche de apoios pelo país”. Radicalizado tal processo, durante as eleições "a campanha tomou as ruas e a aliança governo-movimento se escancarou". ${ }^{402}$ Ao mesmo tempo em que o processo de popularização da política se tornava uma realidade em todos os cantos do país, os bastidores da alta política ferviam, e não eram apenas os conservadores, "vermelhos" ou não, os afetados pelo desenrolar dos acontecimentos.

Setores tradicionais do Partido Liberal assistiam atônitos às mudanças na balança de poder que a todos atingiam. Comprovinciano e aliado tradicional de Dantas e Saraiva, Pedro Leão Veloso alertou este último para a gravidade da situação. "Vê como está baralhado o resultado das eleições?”, interrogava retoricamente o senador baiano ao "messias de Pojuca", acrescentando suas "sinistras previsões" para o desempenho dos correligionários no pleito de dezembro. Os conservadores não mediam esforços para alcançar seus objetivos, "aproveitando-se da anarquia em que o projeto do Dantas deixou o partido liberal". Enquanto em São Paulo uniam-se aos republicanos "contra os liberais, de modo que talvez só venha o Moreira de Barros", na província vizinha de Minas Gerais "também as corujas não mostram sorte risonha para os liberais". 403

400 ACD. 30/07/1884, pp. 382-389.

401 Carta de Francisco Belisário a Paulino de Souza. Petrópolis, 25/01/1885. Biblioteca Nacional. Arquivo Tobias Monteiro, 63,04,002 $\mathrm{n}^{\circ} 105,4 \mathrm{p}$.

402 Ver o vivo relato da autora em Angela Alonso, Flores, Votos e Balas, pp. 245 ss.

403 Leão Veloso a Saraiva, 28/12/1884. AIHGB. Col. Saraiva, DL 273.37. 
A nova lei eleitoral, estabelecendo os distritos uninominais com eleição por voto majoritário, além de permitir que as divisões partidárias locais se expressassem de forma evidente nos pleitos, não sendo raro encontrar diferentes candidatos do mesmo partido concorrendo entre si, permitia também que se firmassem alianças de ocasião com o fim de derrotar um adversário em comum. Isto ocorreu de forma bastante clara em São Paulo, onde, pela primeira vez, dois candidatos republicanos conseguiram se eleger à Câmara dos Deputados, por meio de um acordo com os conservadores. ${ }^{404}$ Os $7^{\circ}$ e $8^{\circ}$ distritos da província enviaram ao Parlamento, respectivamente, Manuel Ferraz de Campos Sales e Prudente José de Morais Barros. ${ }^{405}$

Por sua vez, o ministério e seus aliados não faziam questão de muita sutileza nas tentativas de construir uma maioria viável, nem que para isso tivessem de intervir no equilíbrio tradicional de forças na política partidária. Simbólico da "aliança governomovimento" foi o esforço realizado para garantir uma candidatura forte a Joaquim Nabuco. Antipático ao ministério Dantas, Luís Filipe de Sousa Leão, importante liderança da província de Pernambuco, relatou a grande pressão que sofreu para apoiar e organizar a candidatura do abolicionista em sua província. ${ }^{406}$ Recebendo as visitas de importantes lideranças do partido, Luís Filipe tentou resistir às diversas investidas. Primeiro de Saraiva, que lhe recomendou Nabuco, "concordando entretanto com as objeções" apresentadas pelo correligionário; depois de Sancho Pimentel, então presidente de Pernambuco; e, finalmente, de Silveira Martins, que, com "linguagem mais enérgica", comprometeu, de forma "intimidadora", a distribuição de cargos-chave no funcionalismo da província ao apoio à candidatura pretendida pelo governo. Parecendo-lhe que as palavras do senador riograndense "continham uma ameaça", relatou Luís Filipe ter-lhe respondido "com certa indignação [...] que o Dantas podia proceder como entendesse e que eu estava resignado a ser tratado como inimigo, o que preferia ao abandono dos meus amigos". 407

404 Cf. Milene Ribas da Costa, A implosão da ordem: a crise final do Império e o Movimento Republicano Paulista. Dissertação de Mestrado em Ciência Política, São Paulo: FFLCH/USP, 2006, p. 57. Com mais de dois candidatos concorrendo à mesma vaga, era frequente que nenhum deles atingisse uma maioria simples de votos. Nestes casos, ocorria um segundo escrutínio, em que os dois candidatos mais sufragados se enfrentavam. $\mathrm{O}$ acordo firmado entre conservadores e republicanos, então, era simples: o candidato de qualquer um dos dois partidos que chegasse ao segundo escrutínio receberia apoio de ambas as agremiações para enfrentar o candidato liberal.

405 Cf. Barão de Javari, op. cit., p. 386.

406 Documentos do próprio punho do Cons. Luís Filipe de Sousa Leão relatando conferências políticas. AIHGB. Col. Sousa Leão, DL 456.136.

407 Ibid. Os cargos a que Silveira Martins se referira eram os de desembargador e juiz de direito. Recordando que as emendas conservadoras à lei de 1881 haviam deixado a este último grande poder na formulação do alistamento eleitoral e condução dos pleitos, é interessante constatar que Dantas se 
Apesar de alguns importantes reveses ministeriais, como as derrotas de Mata Machado, ministro de Estrangeiros, e de Rui Barbosa, o resultado do pleito não serviu para tranquilizar a oposição. Foram eleitos 67 liberais, 55 conservadores e 3 republicanos. Ao menos 38 deputados que haviam favorecido o projeto no ano anterior conseguiram um novo mandato, ${ }^{408}$ não sendo difícil prever que o impasse se prolongaria na nova legislatura. Daí a grande consternação de Francisco Belisário, pois qualquer deslize, qualquer concessão poderia significar a derrota de um dos lados: "Se na verificação de poderes alguma coisa se puder conseguir tudo não estará perdido". ${ }^{409}$ Nas semanas seguintes, as comissões responsáveis pelo reconhecimento dos diplomas de deputados se tornariam palcos de intensas batalhas, que constituíram um verdadeiro "terceiro escrutínio".

Um dos parlamentares derrotados durante essa terceira etapa das eleições foi o próprio Joaquim Nabuco. As manobras realizadas por ambos os lados da Câmara para impedir ou postergar o reconhecimento de deputados adversários atingiram em cheio aquele que tinha o potencial de se tornar o principal representante da ala abolicionista do Partido Liberal no Parlamento. Eleito por voto popular, Nabuco teria que esperar um longo tempo até que se procedesse ao reconhecimento de seu diploma. Já após a queda de Dantas, o postulante à bancada pernambucana teve seu mandato invalidado no plenário da Câmara, que reconheceu seu adversário, o conservador Manuel do Nascimento Machado Portela, acusando irregularidades na eleição de Nabuco. ${ }^{410}$

Vários foram os prejudicados pelos embates entre situação e oposição coligada. Entre fevereiro e abril de 1885, a sessão extraordinária, convocada a princípio exclusivamente para a discussão do projeto emancipacionista, acabou sendo totalmente ocupada pela verificação de poderes e pela continuidade da "guerra de emboscadas" que a oposição travava contra o governo. O ministério teve mais uma vez que enfrentar uma decidida dissidência, apoiada pela incansável bancada conservadora. Unidas, tentaram dar-lhe morte rápida, mas Dantas resistiu, até quando foi possível, de forma obstinada, dando ao conflito proporções desmesuradas, que acabaram por envolver com intensidade inédita as forças extraparlamentares no jogo da alta política.

Em meados de março a oposição tentou desferir o primeiro golpe fatal no ministério

utilizava de tais barganhas para avançar os interesses de seu gabinete.

408 Cf. Robert Conrad, op. cit., p. 266.

409 Francisco Belisário a Paulino de Souza. Petrópolis, 25/01/1885. Biblioteca Nacional. Arquivo Tobias Monteiro, 63,04,002 $\mathrm{n}^{\mathrm{o}} 105 ., 4 \mathrm{p}$.

410 Os episódios da campanha eleitoral em Pernambuco e da derrota parlamentar de Nabuco são narrados por Angela Alonso, Joaquim Nabuco: os salões e as ruas, pp. 191-197. 
naquele ano. A eleição da mesa da Câmara se mostrou desfavorável ao governo quando Moreira de Barros, que, a partir de sua demissão da presidência da casa, havia iniciado a fase aguda dos combates políticos no ano anterior, foi reconduzido ao cargo. Com muitos diplomas de deputados ainda não reconhecidos, foram 45 votos para o dissidente paulista contra 34 angariados pelo liberal governista baiano João Ferreira de Moura; três parlamentares se abstiveram. ${ }^{411}$ A oposição coligada alegou que tal resultado constituía uma clara evidência de que o governo não contava com a confiança da casa. Os situacionistas, por sua vez, se defendiam alegando não ser possível conhecer o veredicto real dos representantes da nação sem que todos os deputados estivessem reconhecidos. "Tendo-se achado presentes [no plenário quando da votação] todos os deputados reconhecidos" até então, observou um articulista na Gazeta de Notícias, "verifica-se que 43 distritos eleitorais, dos 125 em que se divide o Império, não se acham representados na câmara temporária". Como poderia ser aceitável propor-se questão de confiança quando um terço da representação nacional ainda não podia tomar parte nas votações, questionou o articulista da folha governista. ${ }^{412}$

Para além de tais inquirições, entre as estratégias dos aliados de Dantas continuava tendo um papel relevante a desqualificação da oposição coligada, à qual se atribuía uma heterogeneidade que colocava em dúvida se tal bloco apresentava condições reais de dar voto político. Não apenas os dissidentes eram pouco coesos, alegavam os próceres da situação, como destoavam completamente de seus aliados de ocasião, os conservadores, em cujas fileiras também não haveria a suposta harmonia que tanto gostavam de propalar:

Ora, ninguém pode dizer que ideia representam os deputados que elegeram o $\mathrm{Sr}$. Moreira de Barros presidente da Câmara; há entre eles conservadores extremados, escravocratas da gema; há conservadores que comungam com os Srs. Barão de Cotegipe e João Alfredo; há conservadores abolicionistas do quilate do Sr. Álvaro Caminha e Antônio Pinto; há liberais que o Sr. Afonso Celso, com a sua grande energia e a sua considerável habilidade política, conseguiria congraçar, e outros que o Sr. Saraiva chamaria ao bom caminho. ${ }^{413}$

Enquanto a sessão extraordinária na Câmara caminhava para o impasse, sem que se procedesse à discussão da reforma servil, o Senado passou a fervilhar com o debate sobre as questões que inquietavam a todos, apesar das observações de alguns dos seus membros

411 Gazeta de Notícias. 14/03/1885, p. 2. A votação ocorreu no dia 12 de março.

412 Ibid., p. 2.

413 Gazeta de Notícias. 16/03/1885, p. 1. Grifo no original. Como veremos, Afonso Celso havia passado a sustentar o ministério. 
quanto ao risco que assumia a câmara vitalícia antecipando uma discussão eminentemente política, que tradicionalmente deveria ser iniciada no outro ramo do Poder Legislativo. Foi em torno dos próprios eventos ocorridos na Câmara que se iniciaram as trocas de farpas entre senadores governistas e oposicionistas.

A oposição adotava a estratégia de desqualificar o gabinete, alegando que sua manutenção prolongada no poder já constituía atentado às instituições. Sua ilegitimidade, segundo tal discurso, era marcante desde o ano anterior, quando, derrotado em votação de confiança, não aceitara o veredicto do Parlamento, dependendo de seu "pacto" com a Coroa para manter-se no poder, anunciando, então, a dissolução da Câmara mesmo sob o risco de "ditadura financeira". Consciente de tal ilegitimidade e da suposta falta de apoio por parte da população do país, o ministério foi obrigado posteriormente, mais uma vez devido ao "amor pelo poder", a intervir de forma inaceitável nas eleições de dezembro de 1884, colocando em risco a herança da reforma eleitoral do início da década. Apesar disso, a oposição havia sido capaz de alcançar número suficiente para derrotá-lo em votação parlamentar, o que não bastou para que reconhecesse a ilegitimidade de sua permanência à frente dos negócios públicos. O conservador Manuel Francisco Correia resumiu tais objeções citando as analogias irônicas de um jornal oposicionista, o Diário do Brazil:

O ministério ainda não achou meio e modo de morrer que lhe agrade; está como uma personagem que, para ser enforcada, a única árvore que encontrou foi um pé de couve; entende que ao condenado, e não à justiça, é que compete escolher o lugar, a ocasião e o gênero de morte. ${ }^{414}$

O "pé de couve" continuava sendo o projeto emancipacionista de 15 de julho. Injustificável, alegava outro destacado senador conservador, era que o governo se arrogasse o direito de, ditatorialmente, impor aos representantes da nação quando e onde poderiam apresentar moção de desconfiança. Ora, se indignava o baiano João José de Oliveira Junqueira, não bastassem os supostos abusos cometidos pelo governo durante as eleições, este agora menosprezava a resolução dos deputados que haviam eleito Moreira de Barros presidente da câmara temporária. "Oportunista", o governo se recusava a reconhecer o "repúdio formal" que partira dos representantes da nação, alegando que sem o reconhecimento de "meia dúzia de deputados" não havia representação nacional. "Onde se disse", interrogou Junqueira, "que o voto da câmara, para ser válido, legal e 
constitucional precisa ser dado por todos os membros da mesma câmara?" ${ }^{415}$ Era, para o Diário do Brazil, citado por Correia, "um sistema representativo e parlamentar inteiramente original" que inventava o presidente do Conselho, declarando "não fazer caso de votos de confiança" e só aceitando "batalha na questão servil". 416

Secundado por José Bonifácio e negando conhecer qualquer irregularidade cometida nas eleições, Dantas defendeu seu procedimento. Afirmando terem sido a dissolução e as eleições realizadas em torno do projeto do elemento servil, observou que as atenções deviam aí se concentrar, sendo esta a única questão política aceitável até que fosse solucionada. Era preciso, de acordo com o presidente do Conselho, que houvesse "solução regular e imediata sobre o ponto que motivou a convocação extraordinária", mas nas condições em que o Parlamento se encontrava, não havia quem pudesse "responder pelos votos dos que não estão reconhecidos". De qualquer forma, ninguém tinha o direito de excluir esses representantes da nação "de tomar parte principalmente na questão da emancipação dos escravos, questão que deu lugar à dissolução da câmara dos deputados". Não podia a Câmara, para José Bonifácio, prejudicar o recurso constitucionalmente interposto pelo governo. Em tal "assunto gravíssimo”, questionou Dantas, poder-se-ia,

por uma estratégia parlamentar em uma questão em que toda a nação brasileira tem os olhos sobre nós, despedir um ministério que empenha sua vida na solução desse negócio [...] a solução dessa questão, tirando-a do terreno em que ela está colocada para, por um simples manejo, aproveitando circunstância ocorrente, qual a de apurarem-se mais prontamente estes do que aqueles diplomas? ${ }^{417}$

"Pretende-se", criticou por sua vez Cristiano Otoni, "que representantes de 80 distritos eleitorais respondam à consulta feita à nação, eliminando da resposta os representantes de 40 distritos eleitorais". Sendo tal procedimento "impróprio" a um sistema parlamentar, o senador pelo Espírito Santo sugeriu que a oposição cumprisse seu papel constitucional e iniciasse a discussão do projeto ministerial, em vez de tentar impedir a qualquer preço que ele se tornasse objeto de apreciação parlamentar. ${ }^{418}$ Se o que unia os liberais dissidentes e conservadores que haviam eleito Moreira de Barros era o repúdio à forma como o governo lidava com a questão da emancipação, seria de se esperar que, para darem voto político capaz de destituir Dantas e seus colegas, os oposicionistas possuíssem ideias próprias e

415 Ibid., pp. 27-28.

416 Ibid., p. 31

417 Ibid., p. 29

418 AS. 19/03/1885, p. 47. 
harmônicas sobre como solucionar tal problema. Do contrário, deveriam resignar-se e aceitar o debate das propostas governamentais:

Ao que se diz os 45 que se pronunciaram na eleição da mesa, contra o ministério, não formam um partido; são a reunião dos conservadores da câmara com os liberais que nesta questão [servil] somente, dizem eles, estão separados dos seus correligionários; e crê-se geralmente que para uma organização [ministerial] os dois grupos não se entenderiam.

Se assim é, a consequência é que esses 45 não representam um partido capaz de governar, e então não podem ter a faculdade de derrubar um ministério. ${ }^{419}$

Correia retomou a palavra pouco depois para fazer novas acusações ao governo. Ecoando as considerações realizadas por lideranças oposicionistas no ano anterior, o senador pelo Paraná indicou que o único modo de se resolver a questão do elemento servil seria pelo envolvimento dos dois partidos constitucionais na busca por uma solução de compromisso. Correia afirmava "haver mais razão para um acordo dos partidos para a solução da importante questão servil do que tinha havido para a reforma eleitoral”. Não só Dantas havia recusado o concurso dos representantes da nação, politizando e partidarizando tal questão, como despertara ódios e reacendera "paixões felizmente amortecidas" com sua intervenção indevida no pleito do ano anterior, contribuindo "para o fato de ter criado no Brasil uma situação de vencedores e vencidos". ${ }^{420}$ Dantas descartava, sugeria o senador pelo Paraná, a herança da reforma eleitoral, como compromisso suprapartidário e como meio de "moralizar" as eleições no país, mesmo tendo sido, ele próprio, peça fundamental na consecução de tão louvável legislação. Era de se admirar, observou por sua vez Junqueira, "essa evolução ou revolução sem r, tão rápida no governo", cujo chefe apoiara o ministério anterior, liderado por Lafaiete, que menos de um ano antes nada cogitara que se aproximasse do radicalismo que agora se via. ${ }^{421}$

Correia e Junqueira, dois senadores conservadores, davam um primeiro passo na direção de uma sensível mudança de ênfase por parte de setores da oposição. Permanecia a retórica, explicitada no ano anterior, que acusava o ministério de politizar uma questão eminentemente social, esperando apoio e compromisso não dos partidos constitucionais, representantes dos interesses "estáveis" da sociedade e a quem deveria caber a palavra

419 Ibid., p. 48.

420 Ibid., p. 54.

421 AS. 20/03/1885, pp. 64-68. 
final sobre a questão, mas de setores "radicalizados" e "movediços" da sociedade. ${ }^{422}$ Ia-se além, no entanto, ao se remeter à reforma eleitoral e à singularidade do ministério Dantas dentro de uma situação política até então pouco afeita a radicalismos. Recordava-se aos liberais que haviam alcançado a eleição direta transigindo com seus adversários naturais e não alienando-os, como fazia o presidente do Conselho, que, por um lado, apelava a um suposto pacto com a Coroa e, por outro, a uma temerária aliança com os "incendiários" para assim prescindir do concurso de metade da representação nacional na resolução da questão mais importante que o país enfrentara em sua história. O chamado à negociação se explicitaria pouco depois.

Após Junqueira deixar a tribuna, foi a vez de Afonso Celso discursar. ${ }^{423}$ A posição do senador mineiro em relação ao ministério havia passado por algumas mudanças desde o ano anterior. Apesar de discordar do projeto de 15 de julho em diversos pontos, inclusive no que dizia respeito à ausência de indenização aos proprietários de escravos sexagenários a serem libertados pelo Estado, Afonso Celso previa prejuízos demais ao país se a questão não fosse solucionada com urgência pelos poderes constituídos. Era, para o senador mineiro, mais "inconveniente e perigosa" do que o projeto do governo a "permanência do statu quo". Deste modo, gostaria de ver o projeto emendado e moderado, mas se a oposição continuasse a se recusar a discuti-lo e apresentar ao país seus planos e propostas, votaria na versão apresentada pelo governo, mesmo se ela passasse sem alterações pela câmara temporária. Pragmatismo e prudência exigiam que os homens de Estado cedessem, pois, do contrário, poderiam ser engolidos pela tempestade:

O statu quo não pode manter-se; ninguém se iluda. Quaisquer que fossem as causas determinantes desse fato, a propaganda libertadora desenvolveu-se, ganhou terreno e hoje impõe-se a todos os espíritos. Agora só resta encaminhá-la e dirigi-la de modo a atenuar os sacrifícios dos interesses que ela combate, e impedir que se desvaire.

$[\ldots]$

O fato inegável é esse: hoje não há ponto nenhum do Império onde não se pense e não se discuta a questão da emancipação; onde essa ideia não fomente alegrias, ou desperte receios.

$[\ldots]$

Dos males, pois, preferirá o menor; em falta de projeto melhor organizado, aceitará o do governo. ${ }^{424}$

422 Ver, por exemplo, Atas do Conselho de Estado Pleno. Terceiro Conselho de Estado. Sessão de $29 / 07 / 1884$.

423 AS. 20/03/1885, pp. 68-70.

424 Ibid., p. 68. 
Não era possível, contudo, que a questão caminhasse sem que os conservadores dessem a ela impulso ou, ao menos, interrompessem a resistência. Se o "pontífice máximo" daquele partido já havia dado sinais de que estava disposto a aceitar que algo se fizesse pela emancipação, era injustificável que a mais alta "trindade" conservadora mantivesse o país no escuro quanto à possível existência de um projeto próprio para a extinção gradual da escravidão. Não era correto, destacou Afonso Celso, em um regime constitucional representativo, que a oposição lutasse pelo poder sem expor ao público suas pretensões em caso de sucesso. "Para homens do mérito" de Cotegipe, João Alfredo e Paulino de Souza "só há um meio nobre e honroso de obter o governo: é conquistarem-no da tribuna, ou da imprensa, em nome das ideias de que se constituírem instrumento". Se o Partido Conservador queria, devia e, mais importante, podia realizar a emancipação, observou Afonso Celso, era de se esperar que seus principais líderes tivessem chegado a um acordo sobre como fazê-lo, o que significava que as cisões herdadas de 1871 haviam desaparecido e a união reinava nas suas fileiras. Do contrário, não podia esperar alcançar o poder. ${ }^{425}$

As provocações de Afonso Celso, ao citar nominalmente seus adversários, dificilmente poderiam ficar sem resposta. Não era possível a Cotegipe, então presidente do Senado, manifestar-se sobre tais assuntos, mas, nos dias seguintes, Paulino de Souza e João Alfredo finalmente romperam o silêncio público que guardavam desde o ano anterior. Estreando na tribuna do Senado, o fluminense foi o primeiro a responder a seu colega liberal. $^{426}$

Era verdade, reconheceu Paulino, que havia sido o líder da resistência à iniciativa emancipacionista do ministério Rio Branco, que agora defendia, em seu nome e de seus aliados, como referência absoluta na resolução do problema servil. Sua atitude havia sido, naquele momento, a de um genuíno conservador: resistindo até o fim para evitar que a questão se precipitasse, porém reconhecendo a derrota e a legitimidade da legislação aprovada pelo Parlamento e sancionada pela Coroa. Uma vez promulgada, portanto, asseverou o senador fluminense, a libertação do ventre tornara-se a palavra final no processo de extinção da escravidão no Brasil, não sendo cabível ou justificável nenhuma outra medida que a colocasse em dúvida ou prejudicasse a execução de suas disposições:

A lei de 28 de setembro de 1871 resolveu por uma vez a questão da emancipação 
do elemento servil. Para afirmá-lo louvo-me nas palavras e declarações explícitas do ilustre estadista que presidiu à sua decretação. Nela estão os princípios fora dos quais não há solução possível sem desorganização do trabalho agrícola, sem atentado contra o direito de propriedade, assegurado na constituição do Império como uma das garantias dos direitos essenciais do cidadão brasileiro. É contra o pensamento dessa lei que se levanta hoje o nobre presidente do conselho, tentando fazer decretar o esbulho e promovendo a emancipação em massa, quando o legislador de 1871 a concebeu operando-se gradualmente, sem abalos sensíveis $\left[\ldots . .{ }^{427}\right.$

João Alfredo também atendeu ao chamado de Afonso Celso e foi à tribuna se manifestar. ${ }^{428}$ Destoando de Paulino, o senador pernambucano confirmou reconhecer a necessidade premente de se adiantar o processo de emancipação, respeitando-se o direito de propriedade dos senhores de escravos e garantindo-se que não haveria desorganização do trabalho nem perturbação das "forças produtivas do país". Para tanto, contudo, tais reformas não podiam ser deixadas a cargo do ministério Dantas, que "tudo anarquizava". Transigindo com o abolicionismo, o presidente do Conselho e seus aliados, criticava João Alfredo, não só faziam vistas grossas aos excessos do movimento, como permitiam que influenciasse o processo de emancipação, o que causava incertezas e inseguranças, assombrando a lavoura. ${ }^{429}$ Destarte, o conservador pernambucano soava menos intransigente que Paulino de Souza, mas também deixava claro que não aceitaria nenhuma solução que partisse do ministério chefiado por Dantas.

As fissuras intestinas do Partido Conservador começavam a se manifestar de forma mais evidente, e a coesão que ainda se mantinha parecia estar ligada ao repúdio compartilhado em relação ao gabinete de 6 de junho. Tentar golpear o governo por meio da dissidência sem permitir que fosse colocado em discussão o projeto ministerial ainda se configurava como a alternativa mais viável a um partido cujos líderes destoavam de forma significativa quanto ao meio mais apropriado para se abordar a questão servil. A resistência os mantinha unidos, mas a possibilidade de uma atitude propositiva se tornava mais intrincada na medida em que um setor importante do partido não reconhecia haver alternativa à reação intransigente.

Pressionado, João Alfredo concluiu seu discurso de forma insólita. Afirmando desejar, aos adversários liberais, sucesso em sua empreitada emancipacionista, o senador pernambucano apelou ao estadista que, cinco anos antes, havia sido capaz de unificar seu partido e compor com a oposição para realizar a grande reforma de então, que transformou

427 Ibid., p. 84.

428 AS. 26/03/1885, pp. 102-106.

429 Ibid., pp. 104-105. 
o sistema eleitoral do país:

Em conclusão, senhores, o meu desejo é que o governo liberal seja tão feliz que possa achar e dar uma solução a este gravíssimo problema. A mim parece que o obstáculo principal é o honrado Sr. presidente do conselho. S. Ex. agitou por tal modo a questão, desencadeou tantas paixões, criou tais perigos, preparou uma situação tão difícil para uma classe importantíssima da sociedade, mostrou-se tão partidário, que é impossível esperar que caminhe com felicidade, com o ânimo pacífico e prudente, como deve ser o daquele que tem de resolver assunto de tanta magnitude.

Sr. presidente, para dar uma prova de minha cordura, não me assentarei sem fazer um voto sincero.

Se me fosse possível arrancar o sábio Nestor daquela penumbra (apontando para a cadeira do Sr. Saraiva) em que modestamente se retrai, dir-lhe-ia: 'É chegada a ocasião de compor as contendas de Aquiles e Agamenon', e pode S. Ex. contar com os meus aplausos se acolher este voto (Muito bem; muito bem. O orador recebe felicitações). ${ }^{430}$

A estratégia de Afonso Celso foi bem-sucedida. Após as falas de líderes importantes do partido oposicionista, ficou evidente haver sensíveis diferenças entre eles. Para Paulino de Souza, qualquer adiantamento da emancipação, qualquer complemento à lei de 1871 soava como atentado à essência de tal lei, colocando-a em xeque como palavra final no processo de emancipação. João Alfredo, por outro lado, reconhecia que a herança do Ventre Livre deveria ser respeitada, mas também levada a um novo estágio por medidas que, nela inspiradas, tornassem mais vigoroso e eficiente o processo de emancipação. A crescente agitação nas cidades e no meio rural contribuía para que setores moderados do Partido Conservador passassem a reconhecer publicamente que apenas resistir era muito mais perigoso do que fazer algumas concessões.

Nesse sentido, Afonso Celso não tardou em observar que, após os discursos de seus adversários, ficara evidente que, naquele momento, somente no terreno da resistência poderiam se manter os conservadores, enquanto não sanassem suas divisões internas para, então, adotarem uma postura propositiva. Não admitindo "um passo adiante" da lei de 28 de setembro de 1871, Paulino de Souza, que representava "uma legião [...], senão toda, grande parte da numerosa falange, que tem assento na câmara dos Srs. deputados”, parecia um obstáculo intransponível à transigência expressada por alguns dos seus correligionários. Por este motivo, era de se esperar, para o senador mineiro, que "se os conservadores tivessem de resolver a questão como governo, veríamos reproduzir-se a cisão de 1871, 
porventura mais profunda, o que seria para lamentar-se". ${ }^{431}$

De forma ainda mais significativa, as diferenças de expectativas e projetos entre liberais e conservadores, se tornavam aparentemente irreconciliáveis. O "golfo" que, segundo o político conservador Teodoro Silva, se referindo às diferenças entre os partidos, não era "tão profundo que não se pode unir uma à outra margem", ${ }^{432}$ parecia ganhar outras dimensões, ao longo das disputas políticas do primeiro semestre de 1885 , no que se referia ao próprio reconhecimento da legitimidade da escravidão e ao papel do Estado na sua extinção.

"Repilo", chegou a asseverar, no Senado, o presidente do Conselho, "a opinião dos que entendem que a propriedade escrava se pode resolver e apreciar pelo mesmo modo por que se considera e garante a propriedade comum". ${ }^{433}$ Para o conservador baiano Joaquim Jerônimo Fernandes da Cunha era uma "heresia" o que dizia o chefe do governo, mas Dantas não se intimidou e disparou: "indenizar pecuniariamente neste século, com as ideias que temos, o valor de homens de 60 anos, seria a meu ver uma monstruosidade". ${ }^{434}$ Silveira Martins, Cristiano Otoni e José Bonifácio foram ainda mais longe que o presidente do Conselho, negando à propriedade escrava qualquer legitimidade e apontando-a como um mero fato transitório, sustentado mais por condições contingenciais do que pelo aparato legal do país. Sem base no direito, observou o senador riograndense, a propriedade escrava era apenas possível pelo concurso do Estado, coagindo o cativo ao trabalho, e da sociedade, reconhecendo-a. Sem estas bases de sustentação, sua extinção total era uma mera questão de tempo e oportunidade. ${ }^{435}$ Para o senador paulista, por sua vez, o projeto de 15 de julho tinha "essa grande virtude - definir o ponto da luta e precisar o objeto da batalha", em torno de uma questão que, ao contrário do que muitos pregavam, era essencialmente política. ${ }^{436}$

Nesse sentido, o ministério já havia alcançado, para José Bonifácio, uma primeira vitória, ao levar até os mais obstinados conservadores a expressar publicamente apreço pela lei de 1871 e defendê-la. Todos os "proeminentes chefes conservadores do senado", asseverou, não sem ironia, o liberal paulista, "querem a emancipação; todos pelo menos, receiam embargar-lhe a marcha, ou sentem-se, como homens políticos, demasiadamente

431 Ibid., p. 113.

432 Brazil. 29/09/1884, p. 1.

433 AS. 27/03/1885, p. 121.

434 Ibid., p. 121.

435 AS. $08 / 04 / 1885$, p. 30

436 AS. 10/04/1885, p. 53. 
fracos para deter a corrente". ${ }^{437}$ Deste modo, a importância da superação do escravismo e a urgência que a nova situação política havia a ela conferido não permitiam mais tergiversações e meias palavras. José Bonifácio não hesitou: “Os sexagenários do contrabando secular não devem indenização alguma". ${ }^{438}$

Se colocadas lado a lado as palavras de conservadores e liberais governistas, podemos entrever o significado profundo que tomava a luta política naqueles primeiros meses de 1885. Por serem particularmente ilustrativas, tomemos as declarações de dois dos mais destacados chefes dos partidos constitucionais, João Alfredo e José Bonifácio.

Em outro trecho de seu discurso já acima citado, ${ }^{439}$ o senador pernambucano asseverou serem "piores do que as disposições do projeto [emancipacionista] e altamente injustos e cruéis" os meios que utilizava o governo "para chegar ao seu fim". Tendo atingido "o ponto de agitar todas as paixões, de pôr em perigo todos os interesses estáveis da sociedade, permitindo a prática de atos criminosos e anárquicos", o ministério Dantas representava não a "autêntica" e "generosa" ideia da emancipação dos escravos, mas o sequestro de tal ideia por setores intransigentes e radicalizados da sociedade e da política imperial, disputando com os "interesses estáveis" da nação, legitimamente representados no Parlamento, a influência decisiva sobre o encaminhamento da questão servil. Nesse sentido, declarou João Alfredo:

Ninguém aspira com mais ardentes votos do que eu a extinção da escravatura no Brasil, mas desejo a reforma com espírito e processo conservador. Desejo ver a corrente da opinião, que está formada, prosseguir dentro da lei, sem ofensa dos princípios fundamentais da sociedade, como o rio, que embora volumoso e rápido, corre pacificamente em seu leito sem transbordar. ${ }^{440}$

Almejada por todos os brasileiros, que, por seu "caráter generoso" e "abnegação" já haviam feito inúmeras concessões para apressar sua solução, ${ }^{441}$ à emancipação dos escravos não deveria ser atribuído um caráter político ou partidário. Se o país todo a aceitava e a desejava, havendo apenas algumas discordâncias quanto a prazos e oportunidades, aquela era uma questão eminentemente social, que convidava os homens de Estado ao compromisso mútuo e a realizar concessões, para que, dentro da ordem e da

437 Ibid., p. 54.

438 Ibid., p. 56.

439 AS. 26/03/1885, pp. 102-106.

440 Ibid., p. 106.

441 Ibid., pp. 104-105 
legalidade, fosse terminada a grande obra.

Não tinha outro sentido o apelo de João Alfredo a Saraiva. ${ }^{442}$ O "sábio Nestor", que havia realizado a reforma eleitoral sacrificando muitos dos elementos mais adiantados do programa de seu partido em nome da transação com os adversários, apresentava-se agora, numa questão ainda mais grave e decisiva, como o símbolo do compromisso suprapartidário necessário para a consecução das grandes questões que agitavam o país, e que deveriam ter sempre pelas vias parlamentares sua solução.

Significados diametralmente opostos ganhavam, por sua vez, as palavras de José Bonifácio. ${ }^{443}$ Para além da desforra contra seus adversários, a quem via capitulando fosse frente à lei de 1871, que muitos haviam decididamente rejeitado, fosse em relação a concessões ao adiantamento da emancipação, que outros tantos temiam, o senador liberal desnudava os motivos por trás da feroz oposição ao gabinete. Mais do que reconhecer a importância de se proceder a uma nova intervenção do Estado na instituição servil, Dantas apresentara um projeto que não isolava a emancipação dos escravos como um tema a ser tratado à parte, mas assentava claramente suas íntimas relações com todos os outros assuntos que interessavam ao país, incluindo na sua consecução amplos setores da sociedade, daqueles que, mesmo não possuindo escravos, deveriam pagar novos tributos para a ampliação do fundo de emancipação, aos próprios cativos, que, libertados, deveriam passar do domínio de seus senhores à tutela do Estado. Este, por meio do projeto de 15 de julho, lhes prometia até mesmo o acesso à terra, além de abrir possibilidades para que o estado servil de muitos fosse legalmente questionado, por meio de uma matrícula que exigia declaração de naturalidade e poderia encetar inúmeros processos de libertação baseados na vigência da lei antitráfico de 1831. Para José Bonifácio, parecia ser fundamental que a discussão sobre os meios de se solucionar a questão servil fosse, de uma vez por todas, reconhecida não como o apanágio exclusivo da lavoura e de seus representantes no Parlamento, mas como prerrogativa essencial de todos os brasileiros. Mais do que um "cancro social”, aquela era uma questão política por excelência, que continha em si alguns dos mais relevantes dilemas que enfrentava o país, bem como suas soluções:

Neste momento a questão servil não é simplesmente uma questão social; é uma

442 Ibid., p. 106.

443 AS. 10/04/1885, pp. 53-62. 
questão política: ela traz nas entranhas a estabilidade no presente e a segurança no futuro; ela sobressalta os espíritos, vendo nos oceanos sem limites um recanto escuro do globo para esconderijo da escravidão: ela aponta mudamente para essa integridade nacional, dividida pelos interesses contraditórios de província livres e províncias escravas, e perguntando se já não é tempo de tornar uma realidade a integridade moral do homem. ${ }^{444}$

Se o advento do ministério Dantas e seu projeto significaram o reconhecimento implícito da impossibilidade de manutenção do status quo e da necessidade da inclusão de novos setores da sociedade imperial nos debates em torno do encaminhamento da extinção do cativeiro, sua trajetória levou à superfície as cisões profundas que dividiam a elite política imperial. Antes sujeita ao acordo tácito entre os dois partidos políticos, que para governar haviam, desde 1871, mantido-a nas sombras, a escravidão foi retirada de seu cativeiro institucional pela crescente radicalização política extraparlamentar, que ajudou a levar ao poder uma fração da elite política imperial disposta a romper o silêncio. Mesmo que tal ruptura tenha sido inicialmente moderada, ainda era uma ruptura, a antítese do silêncio ensurdecedor que reinava, pouco antes, sustentado mesmo por governos liberais, caso dos ministérios Saraiva, que não "cogitara" da questão, e Martinho Campos, autodeclarado "escravocrata da gema".

Paradoxalmente, a reação daqueles que defendiam que o monopólio decisório sobre a questão permanecesse submetido à negociação parlamentar, ajudou a radicalizar a posição do governo e seus aliados, que deram um passo decisivo na solução do problema. $\mathrm{O}$ projeto, que Rui Barbosa mais tarde chamaria de "transação abolicionista", mas que em 1884 chamou de "solução liberal", ${ }^{445}$ se tornou o símbolo de um novo momento político em que o acordo deixava gradativamente de ser uma opção. A obstinação dos conservadores em barrar a discussão do projeto significava uma imputação de ilegitimidade não só a tal projeto, mas também ao gabinete, que estaria fora dos bons hábitos parlamentares, encetando uma disputa eminente e pragmaticamente política entre visões distintas de país, ao invés de dar continuidade ao compromisso silencioso. José Bonifácio registrou as táticas discursivas impiedosas da oposição na interdição prolongada ao ministério:

Em torno do projeto grupam-se todas as censuras ao governo: ele fere a constituição, mutilando uma de suas principais garantias; ele descobre a coroa no

444 Ibid., p. 54.

445 ACD. 28/07/1884, pp. 357-360. 
pacto ministerial e na dissolução das câmaras; ele desconhece as altas responsabilidades de sua missão e as prerrogativas do ramo temporário do poder legislativo, evitando questões de confiança para manter-se alguns dias no poder; ele intervém no pleito eleitoral, juiz e parte ao mesmo tempo, para falsificar a sentença das urnas, por amor de um projeto condenado pelo país; em uma palavra ele tranca as portas do parlamento, esperando compor um tribunal à feição de seus desejos.

A história admirar-se-á um dia que em um Império constitucional representativo a liberdade de velhos sexagenários, carregando nas mãos trêmulas o peso funerário de três séculos de opressão, precisasse ainda de tantos prodígios de generosidade na oposição de uns e de tantos milagres de força na sustentação de outros!...

Contrastes da ingrata e agoureira sorte $!^{446}$

Não obstante o apelo retórico à humanidade dos adversários, José Bonifácio e seus pares sabiam que se encontrava em jogo muito mais do que a sorte de alguns milhares de escravos sexagenários. O sistema político do Império vivia um momento de profunda incerteza.

A recusa da oposição em discutir o projeto do governo e o impasse político no qual se encontrava o país ganhariam contornos ainda mais severos alguns dias depois. Em meados de abril, cerca de dois meses após o início da sessão parlamentar extraordinária, o reconhecimento dos deputados finalmente se aproximava de seu fim. Com mais de cem parlamentares reconhecidos, o governo indicou estar disposto a promover o início da discussão do projeto emancipacionista. No dia marcado, 13 de abril, contudo, antes de qualquer manifestação ou discurso, Moreira de Barros, licenciado da presidência da casa temporária, cumpriu, na condição de líder da dissidência liberal, a missão de apresentar uma moção de desconfiança que atingia um dos âmagos do projeto: "A Câmara dos Deputados, não aceitando o sistema de resolver sem indenização o problema do elemento servil, nega seu apoio à política do gabinete", 447

A apresentação prévia de uma moção, assinada por dez dissidentes, ${ }^{448}$ que o governo não podia rejeitar, por se referir diretamente ao eixo em que, por ele próprio, haviam sido fixadas as questões políticas, isto é, o artigo $1^{\circ}$ do projeto, tinha ainda a contrapartida de versar sobre um ponto do qual Dantas não abria mão. A ausência de indenização pelos escravos sexagenários, o presidente do Conselho já havia declarado diversas vezes, não

446 AS. 10/04/1885, p. 55.

447 ACD. 13/04/1885, p. 313.

448 Além do paulista Moreira de Barros, assinaram a moção seis representantes de Minas Gerais, Afonso Augusto Moreira Pena, Antônio Carlos Ribeiro de Andrada, Benedito Cordeiro dos Campos Valadares, Antônio Felício dos Santos, Sebastião Mascarenhas e João Penido, dois representantes de Alagoas, Lourenço de Albuquerque e João Lins Vieira Cansanção de Sinimbu Júnior, e um deputado pelo Ceará, José Pompeu. Ibid., p. 313. 
estava aberta à discussão. O próprio Moreira de Barros afirmou ser aquele o "ponto" em que o governo estabelecera o embate; e mais, justificando a apresentação da moção:

A dissidência liberal separou-se do governo porque não aceita o sistema de resolver o problema da emancipação dos escravos sem indenização. Este fato deu lugar à dissolução da câmara.

A dissidência, que já considerava conveniente tratar-se deste assunto para apressar-lhe a solução, reputa agora da maior urgência resolvê-lo definitivamente (apoiados), para tranquilizar as classes produtoras justamente alarmadas pela propaganda oficial (apoiados; muito bem). ${ }^{449}$

A dissidência, assim como os conservadores, reconhecia que o projeto emancipacionista de 15 de julho era muito mais do que um simples complemento a uma lei que muitos viam como demasiadamente morosa e ineficiente, a Lei do Ventre Livre; era, essencialmente, a negação de sua disposição gradualista e indenizatória, colocando em xeque a legitimidade da propriedade escrava.

Por outro lado, a cada dia ficava mais explícito, e de forma mais contundente, que o discurso antiescravista dos setores do Partido Liberal mais fortemente ligados ao ministério chegava a um ponto de radicalização sem retorno. O não reconhecimento da propriedade escrava como legítima e uma retórica cada vez mais extremada contra a escravidão, encorpada graças à polarização política que tomava conta do país, significavam ultrapassar limites de forma sistemática até um ponto sem volta. A importância do artigo $1^{\circ}$, que previa, entre outras medidas, a libertação incondicional dos escravos sexagenários, era central a um projeto que "embutia um modelo de nova sociedade pós-escravidão". 450

Após a apresentação da moção de desconfiança, Cândido de Oliveira, ministro da Guerra, levantou-se para demonstrar sua indignação: os dissidentes não podiam afirmar serem genuinamente liberais quando desafiavam de forma tão aberta a autêntica vontade popular, representada pelo partido. ${ }^{451}$ Deste modo, observou o ministro-deputado mineiro:

Pela primeira vez neste país, depois de sessenta anos de regime representativo, assistiu-se ao fecundo espetáculo de ser a nação consultada diretamente sobre um ponto cardeal - sobre a oportunidade de uma grande reforma. Pela primeira vez teve o recurso constitucional da dissolução o efeito de pedir o funcionamento da soberania nacional sobre uma reforma a que se prendiam os mais graves interesses, e de que o gabinete fazia a chave de sua política.

Mas qual era essa política? Em nome de que ideia a consulta era feita? O que é

449 Ibid., p. 313.

450 Cf. Angela Alonso, Flores, Votos e Balas, p. 223.

451 ACD. 13/04/1885, pp. 313-316. 
que o governo queria que fosse julgado pela nação, aqui representada pelos seus eleitos? Era justamente este projeto, cujas doutrinas e princípios dominavam todos os espíritos e nos alentavam nestas lutas enormes, que até hoje temos sustentado, e que se tornaram por assim dizer nossa vida normal.

[...] não obstante todos esses esforços, o partido liberal, certo de que na história não lhe é lícito figurar um só instante como representante do retardamento em tão vital assunto, certo de que a primeira das liberdades é e será sempre a liberdade individual, o partido liberal aqui se acha em sua quase unanimidade sustentando os iniciadores da nova política, destacando-se apenas dez ou doze díscolos [sic]. ${ }^{452}$

A esses "dez ou doze díscolos" deveria ficar muito claro que sobre si pesava "a enorme responsabilidade de cavar profundamente a cisão no partido liberal”. A eleição direta, mesmo com o eleitorado restrito, possibilitara, de forma inédita, que a população fosse consultada sobre uma política de Estado de alta relevância. Não reconhecendo, contudo, a importância de tal avanço ao sistema representativo do país, acusava o ministro da Guerra, a dissidência descartava a herança daquela reforma, impedindo que a nação, por meio da representação parlamentar, oferecesse $\mathrm{o}$ veredicto sobre o projeto emancipacionista.

Em protesto às palavras do ministro da Guerra, um dissidente e seu comprovinciano, Benedito Valadares, denunciou os governistas por desejarem fundar no país uma "igreja liberal", fora da qual não haveria "salvação". ${ }^{453}$ Não cabia, assegurou Valadares, ao ministro e seus aliados, apontarem quem eram os verdadeiros liberais: "a dissidência quer a harmonia de todos os direitos, e é, portanto, mais liberal do que o gabinete". Este não apenas anarquizava o país, como injustiçava a dissidência, que não desejava "abafar a discussão" do projeto, nem "iludir a consulta feita ao país", mas impedir que o governo agisse ilegalmente, desrespeitando o direito de propriedade. A grita das ruas não estava acima da lei, como parecia querer o ministério:

O país tem necessidade de paz e o gabinete é uma ameaça à ordem e à paz pública. Não há exemplo na história de governo que assim tenha procedido; de um governo que ataque a propriedade e a mande ridicularizar por escritores assalariados. Nas grandes reformas os estadistas que as têm empreendido as defenderam em discursos cheios de calma e moderação. ${ }^{454}$

Mais uma vez a suposta intransigência do presidente do Conselho e seu governo aparecia como empecilho a uma solução moderada, negociada e definitiva do problema, 
que, conforme o discurso da oposição, todos desejavam. A disposição à transação passava a ser uma constante em tal discurso, já presente na fala, acima citadas, de João Alfredo, então unido a outros setores moderados do Partido Conservador. Para a dissidência, por sua vez, não se tratava apenas de se agarrar à defesa do monopólio decisório do Parlamento na questão, condenando um ministério visto como pouco comprometido com os "interesses estáveis" da sociedade e sustentado por forças extraparlamentares radicalizadas. Tratava-se também, ficava cada vez mais claro, de disputar a própria essência do Partido Liberal, que o gabinete Dantas havia comprometido com bandeiras e métodos repugnantes para alguns de seus membros.

Cândido de Oliveira, como José Bonifácio e outros próceres governistas, expressavam, em seus discursos, a ideia de que o Partido Liberal era o genuíno representante das aspirações populares que se encontravam fora do Parlamento e que o ministério e seus aliados, por sua vez, encarnavam o autêntico espírito "progressista" e "popular" dos liberais. Ao se referir à nova armadilha em que seu governo se encontrava naquele 13 de abril, Dantas, por sua vez, indicou de forma consideravelmente clara que os termos do combate haviam ganhado uma nova polarização. Colocando-se na posição de futuro mártir da causa da emancipação, caso o voto de confiança resultasse negativo ao ministério, o presidente do Conselho, efusivamente celebrado pelos que se encontravam nas galerias da Câmara, indicou não estar disposto a transação alguma:

[...] se o atual ministério houver de deixar o poder, hipoteco desde já o meu voto ao ministério que tenha de suceder-nos, e que se proponha a realizar tanto ou mais do que desejamos fazer nesta questão (Aplausos).

O Sr. Zama: - E nós todos.

O Sr. Dantas (presidente do conselho): - Não posso, porém, assegurar o meu fraco apoio a ministério que queira recuar uma linha no sistema do projeto de 15 de julho (Novos aplausos). ${ }^{455}$

Comprometendo-se e a seus colegas a caírem "com dignidade abraçados ao projeto de 15 de julho", Dantas dava um passo decisivo para, de uma vez por todas, inaugurar um novo momento político no Partido Liberal, que se desenharia de forma mais clara meses depois. Naquele momento, contudo, o presidente do Conselho deixava uma coisa clara: havia limites para qualquer transação possível, e esses limites se tornavam gradualmente mais estreitos. O significado de uma vitória do governo representaria um ponto sem volta, 
tornando-se transparente a todos que seu projeto contava com o apoio da maioria do país representada no Parlamento. Uma derrota, por outro lado, não causaria o abandono da ideia "generosa" que o ministério 6 de junho representava, até pelo fato de que, sem todos os deputados reconhecidos, tal derrota seria, no mínimo, questionável.

Nem triunfo nem derrota clara, a votação terminou empatada naquele momento, ${ }^{456} \mathrm{e} o$ significado de tal empate passou a ser intensamente disputado por governo e oposição. Como votaram os ministros que eram também deputados, enquanto Moreira de Barros, na condição de presidente da Câmara, foi impedido de fazê-lo, os adversários do ministério argumentaram que sua derrota era evidente. Dantas e seus colegas, por sua vez, rejeitaram tal tese, destacando que a oposição falhava mais uma vez em seu ardil de mostrar-se majoritária enquanto ainda faltava reconhecer diversos deputados governistas. O impasse entrou, então, em uma fase mais aguda.

No dia seguinte, o conservador fluminense Andrade Figueira, "general em chefe das forças coligadas" da oposição na Câmara dos Deputados, ${ }^{457}$ declarou na tribuna que os conservadores "acatariam" o insistente pedido do ministério: não haveria sessão enquanto não estivessem todos os deputados reconhecidos. ${ }^{458}$ A nova tática tinha um sentido evidente: após o insucesso da moção de desconfiança da véspera em demonstrar estar o ministério em minoria, a oposição impediria que houvesse sessão, inviabilizando qualquer discussão do projeto emancipacionista. Para isso, os conservadores se utilizaram da tática de retirada em massa do plenário, bloqueando, por falta de quórum, o funcionamento do ramo temporário do Poder Legislativo. ${ }^{459}$

A "trica" da oposição passou a ser diariamente denunciada pela imprensa, enquanto se especulava sobre as movimentações nos bastidores do Partido Liberal para a substituição de Dantas por outra liderança daquela agremiação, sendo Saraiva o primeiro nome. ${ }^{460}$ A suspensão da vida política do país acabou por gerar um clima de profunda insatisfação na capital do Império. Até mesmo o geralmente neutro e moderado Jornal do Commercio lançou um editorial condenando as atitudes da oposição, que, para a folha, impunham ao país um estado de incerteza inaceitável. Citando boatos que corriam na Corte, de que conservadores e dissidentes, em "conchavo", haviam decidido barrar o reconhecimento de

456 Ibid., pp. 326-327.

457 Andrade Figueira assumiu o papel de líder da minoria conservadora na casa após a nomeação de Paulino de Souza para o Senado.

458 Gazeta de Notícias. 15/04/1885, p. 1.

459 Ibid., p. 1.

460 Ver Gazeta da Tarde, na segunda metade do mês de abril de 1885. 
deputados governistas, na reta final do processo de verificação de poderes, o articulista afirmou preferir não acreditar que representantes da nação se prestariam a tal papel. ${ }^{461}$ Já era fato que até mesmo os mais intransigentes adversários do ministério admitiam a reforma do elemento servil, contanto que Dantas deixasse o poder e se procedesse a uma nova organização ministerial. Ficava a dúvida, contudo, destacou o articulista, em torno do conteúdo de tal reforma. E ainda mais duvidosa continuava sendo a verdadeira capacidade da oposição em formular uma alternativa viável ao gabinete de 6 de junho:

Dizem que é detestável o projeto do Sr. Dantas e que este agitou violentamente a opinião pública. Seja; mas o mal está feito, a opinião violentamente agitada, e que farão agora os varões prudentes? Abrandar o projeto, atenuar a agitação, ou irritá-la, provocando explosão tremenda?

O fato é que a discussão da magna questão foi arrancada das praças públicas e trazida para o parlamento; é perigoso tornar a atirá-la às ruas. ${ }^{462}$

Os alertas feitos pela imprensa se mostravam certeiros no Parlamento. A crescente multidão, favorável ao ministério, que se reunia dentro e fora do edifício da Câmara dos Deputados para acompanhar as sessões parlamentares, se demonstrava cada vez mais indignada com as protelações e os expedientes das comissões de verificação de poderes, cuja isenção havia sido colocada em dúvida. O impasse político e os boicotes da oposição, que se recusava a consentir ao início da discussão do projeto, tentando derrubar o ministério a qualquer custo, acabou por gerar uma radicalização ainda maior daqueles que, fora das instituições políticas, acompanhavam com atenção o desenrolar da "questão servil" no Parlamento. Mobilizados em torno de tudo que significava então o ministério Dantas, esse público crescente e diverso passou a hostilizar cotidianamente os parlamentares da oposição. ${ }^{463}$ Posteriormente, Andrade Figueira faria seu relato de tais acontecimentos:

Um representante do povo foi apedrejado; o presidente da Câmara foi por várias vezes acompanhado por uma multidão que lhe dava vaias furiosas durante longo trajeto pelas ruas mais públicas da capital; o próprio orador foi vítima de uma ameaça ou tentativa de assassinato por um pobre diabo, que afinal entendeu dar fim a seus dias. [...] O governo foi quem açulou, e o nobre deputado [Cândido de Oliveira], então ministro da guerra - ao orador pesa dizê-lo, mas é a verdade que deve à história - deu

461 O editorial foi reproduzido pela Gazeta da Tarde. 17/04/1885, p.2

462 Ibid., p. 2.

463 Em seu relatório final de iniciação científica, Roberto Saba já chamou atenção para a importância da pressão popular no acirramento das tensões que finalmente levariam à derrota do ministério Dantas. Cf. Roberto Saba, A questão servil no debate parlamentar (1885): a Lei dos Sexagenários. Relatório de iniciação científica apresentado à FAPESP, 2007. 
o triste exemplo de aproximar-se das janelas da Câmara, para daí aplaudir aos que vaiavam. ${ }^{464}$

Se entre os grandes crimes de Dantas e seus aliados, para a oposição, se encontrava o de governar com o apoio de forças extraparlamentares radicalizadas, não é difícil imaginar a gravidade que ganharam tais acontecimentos. Deste modo, a permanência do presidente do Conselho à frente dos negócios públicos, se antes já repugnava a muitos de seus adversários, tornou-se intolerável. Ao mesmo tempo em que, por um lado, setores cada vez mais significativos do Partido Conservador e da dissidência liberal consentiam na necessidade urgente de se solucionar o impasse em relação à questão servil, tendo em vista sua intensa e potencialmente incontrolável radicalização, por outro não aceitavam qualquer solução que partisse do ministério então no poder. Para além de propor um projeto "abolicionista", Dantas e seus aliados haviam comprometido o Partido Liberal com a "anarquia" das ruas, pondo em risco, na interpretação de seus adversários, a própria sobrevivência das instituições. Retirar do poder o ministério de 6 de junho se tornou, então, caso de "salvação pública".

A tensão da situação fez com que algumas lideranças do Partido Liberal passassem a procurar alternativas ao impasse. A gota d'água veio quando da publicação de um editorial da abolicionista Gazeta da Tarde, em que se conclamava a população da Corte e a própria Coroa à "revolução", se os "escravagistas" continuassem a bloquear as iniciativas ministeriais. Era preciso que se dissolvesse a Câmara intransigente:

As dissoluções sucessivas são um golpe de estado prolongado, uma ditadura temporária. De acordo, mas é indispensável.

De duas, uma: ou o imperador faz a revolução, ou o povo a fará. A nossa situação é para Turgot ou para a Convenção. Querer mascará-la, dissimulá-la, é um perigo. ${ }^{465}$

As manifestações populares nas ruas e na imprensa fizeram com que a oposição mudasse de estratégia e passasse a questionar a capacidade do ministério em garantir a integridade dos representantes da nação. $O$ primeiro a levantar tais problemas no Parlamento foi Manuel Francisco Correia, que, após colocar em dúvida a viabilidade política do gabinete, interrogou se este dispunha de "todos os meios para manter a ordem pública”. Martinho Campos, que voltara à ativa, respondeu friamente, em aparte, que o 
governo tinha "de sobra" tais meios, desde que quisesse utilizá-los. Correia, então, formulou a acusação final em tom de inquirição: "está disposto o governo a impedir que os deputados sofram desacatos?"

Poucos dias depois do editorial "revolucionário" da Gazeta da Tarde, um dos principais sustentadores do ministério até então, o senador Silveira Martins, expôs à câmara vitalícia suas preocupações quanto às palavras da folha abolicionista e à crescente instabilidade na capital do Império. O liberal riograndense iniciou sua fala interpelando o ministério de forma inusitada, para alguém que não havia publicamente retirado seu apoio ao governo. Questionando seu procedimento na votação de 13 de abril, Silveira Martins afirmou ter sido o gabinete derrotado naquela ocasião; sendo que o não reconhecimento da derrota apenas demonstrava sua fraqueza. Uma postura ainda menos aceitável do ministério era aquela relativa à sua tolerância em relação às manifestações populares mais exaltadas. Tornava-se urgente que se resolvesse o impasse político, o que o próprio senador riograndense havia tentado ao se reunir com a dissidência do Partido Liberal na expectativa de alinhavar um acordo. ${ }^{467}$ Mostrando-se "razoáveis e dispostos à concórdia", até mesmo no que dizia respeito ao projeto emancipacionista, os dissidentes, segundo o orador, não cediam em um ponto: haviam perdido por completo a confiança no gabinete, e se recusavam a fazer qualquer concessão a Dantas. “A confiança não se impõe!”, bradou Silveira Martins. ${ }^{468}$ Nesse sentido, observou o senador, a manutenção do ministério no poder, à revelia do apoio do Parlamento, poderia significar o falseamento das instituições: a "consequência do erro do nobre presidente do conselho", manifestou Silveira Martins, era "um estado de indecisão no governo", que trazia "o espírito público agitado, a lavoura atemorizada, o comércio paralisado, diante dos elementos de perturbação da ordem que a fraqueza do governo alenta". ${ }^{469}$ Não sendo possível "confiar na ordem pública" diante de tais fatos, "terríveis sintomas das alterações profundas no organismo social", era preciso que Dantas despertasse para a realidade de que "governo e anarquia são duas ideias que se repelem":

[...] peço ao nobre presidente do conselho, de novo, que se desprenda do elemento desordeiro de que talvez muito involuntariamente tem-se cercado.

Este elemento compromete o partido liberal porque põe em perigo a ordem

466 AS. $17 / 04 / 1885$, p. 80.

467 AS. 20/04/1885, pp. 87-89.

468 Ibid., p. 88.

469 Ibid., p. 88. 
pública (Muitos apoiados; muito bem) ${ }^{470}$

A condenação de Silveira Martins à suposta incapacidade do ministério em conter as manifestações populares pareceu, então, à Gazeta da Tarde, um expediente de setores do Partido Liberal para afastar o presidente do Conselho do poder e atenuar as graves tensões políticas. "[U]m dia sans-culotte, outro dia mandarim chinês", o político riograndense traía, para a folha abolicionista, uma causa que historicamente defendera. Os liberais pareciam, em nome do poder, capitular frente às pressões da oposição coligada:

Acentua-se em alguns chefes liberais a impaciência pela solução do atual estado de coisas.

Acreditam eles que o Sr. presidente do conselho quer glórias demais; que ele se deve contentar com os louros já colhidos, os louros do sacrifício, o cálix de fel do pleito eleitoral, os incômodos da trica, a responsabilidade tremenda de pôr em perigo a sorte dos candidatos que lhe sufragarem o projeto.

S. Ex. deve deixar o poder, para que outro chefe - são muitos os que estão diante da Tebas governamental - se coroe com as palmas cultivadas pelos sofrimentos do político audaz, que tem a coragem de se comprometer a não parar, não recuar, não precipitar, e deu ao país o nobre exemplo de desempenhar a sua palavra.

Nada mais natural do que ver destacar-se amanhã um grupo da maioria e desfechar em nome dela o golpe no gabinete. ${ }^{471}$

A resposta às colocações de Silveira Martins vieram de aliados do ministério e do próprio presidente do Conselho. Silveira da Mota, Franco de Sá e Dantas defenderam, em linhas gerais, a tese de que a oposição desejava "amordaçar a opinião". Para eles, havia exagero nas considerações sobre as presumidas ameaças à ordem pública. O ministério não se havia cercado dos supostos "elementos de desordem" com intenção de coagir os adversários e atingir seus objetivos, mas encontrara tais setores a seu lado desde o início. Havia, deste modo, legitimidade nas manifestações populares, na imprensa ou nas ruas, dentro dos limites da boa convivência. E mais nocivo ao sistema representativo, defendiam, era o procedimento da oposição, que tentava de todas as formas barrar a discussão do projeto ministerial, negando ao país a oportunidade de debater e solucionar tão momentoso assunto. $\mathrm{O}$ ministro do Império se indignou: “O partido liberal, que escreveu em seu programa reforma ou revolução, a reforma para evitar a revolução, não pode tomar-se de pavor só por dizer algum escritor mais exaltado: - Faça-se a reforma para se não fazer a

470 Ibid., p. 89.

471 Gazeta da Tarde. 18/04/1885, p. 1. 
revolução". ${ }^{472}$ Para Franco de Sá, os "governos livres" não deviam dar "demasiada importância a desabafos de opiniões ardentes, com relação a um assunto que tanto a isto se presta". 473

As explicações e justificativas não ajudaram a acalmar os ânimos. Após deputados oposicionistas sofrerem vaias e terem sua integridade física colocada em risco por "maltrapilhos" que se postavam no exterior do prédio da câmara temporária, outro antigo apoiador do ministério se bandeou para a oposição. O deputado pernambucano Antônio de Siqueira foi à tribuna acusar o ministro da Justiça, Francisco Sodré, de ser responsável pelas constantes desordens. Seriam os desordeiros, para Siqueira, "capangas" pagos pela polícia para constranger os adversários do ministério. $\mathrm{O}$ desiderato de um governo identificado com a "propaganda", disparou o neo-dissidente, era a cumplicidade com a ilegalidade, onde o ministério Dantas procurava "recursos para sua vitória". ${ }^{474}$ De nada adiantou que o ministro da Guerra, Cândido de Oliveira, realizasse uma nova defesa do procedimento do gabinete, que trouxera "para o recinto do parlamento, para o terreno da legalidade a questão que pairava nos ares e agitava o país", ${ }^{475}$ pois os dissidentes apresentaram uma nova moção de desconfiança. Como previra a Gazeta da Tarde ${ }^{476} \mathrm{o}$ golpe de misericórdia partiu de um membro da maioria, Antônio Manuel de Siqueira Cavalcanti, descolado de seus antigos aliados: "A câmara dos deputados, convencida de que o ministério não pode garantir a ordem e segurança pública, que é indispensável à resolução do projeto do elemento servil, nega-lhe sua confiança". ${ }^{477}$

Mesmo tendo demonstrado mais uma vez força, ao obter um considerável apoio, o ministério não foi capaz de resistir; uma diferença de dois votos - 52 a 50 - decretou seu fim. ${ }^{478}$ Ficava claro que, para seus adversários, se o projeto de 15 de julho era o grande equívoco do gabinete chefiado pelo conselheiro Dantas, a natureza de sua política se constituíra em um crime imperdoável. Não se contentando em "politizar" a questão servil, transformando-a em matéria eleitoral, o ministério encetou a identificação entre o Partido Liberal e o movimento abolicionista, reconhecido como ator político legítimo, tendo em

472 AS. 21/04/1885, p. 114

473 Ibid., p. 114.

474 ACD. 04/05/1885, pp. 3-7.

475 Ibid., pp. 7-9.

476 Gazeta da Tarde. 18/04/1885, p. 1.

477 A moção e a discussão que encetou encontram-se em ACD. 04/05/1885, pp. 3-12. Foi assinada por seis dissidentes, além de Antônio de Siqueira: Benedito Valadares, Afonso Pena, João Penido, Felício dos Santos, Lourenço de Albuquerque e José Pompeu. 478 Ibid., pp. 11-12. 
vista que a dissidência não representava mais do que uma pequena minoria frente à resiliente base de apoio dantista.

Pelo que foi exposto até aqui, pode-se afirmar que os combates entre junho de 1884 e maio de 1885 criaram situações novas em ambos os partidos monárquicos. Entre os liberais, marcaram um momento de fortalecimento e expansão da ala mais extremada do partido, ligada, ou ao menos receptiva, a influências e movimentações políticas extraparlamentares de caráter radicalizado e sustentadora de um abrangente projeto antiescravista para o país. Entre os conservadores, por outro lado, engendraram uma cisão decisiva entre moderados e "vermelhos", logo "alfredistas" e "paulinistas", que, como veremos, a figura imponente do barão de Cotegipe tentaria, sem sucesso, conciliar. Acima de tudo, o processo de popularização da política mostrou-se uma realidade incontestável, e o novo poder das ruas, da imprensa, dos meetings, enfim, das forças extraparlamentares, com quem uma fatia não desprezível da elite política imperial mostrou-se disposta, ou constrangida, a dialogar, expôs cruamente que se abria um novo, e crítico, momento na política brasileira.

A feroz oposição que sofreu o ministério Dantas parece, portanto, ter ido muito além da questão servil. Esta, explosiva e tendente à exposição e aprofundamento de clivagens, acabou encetando uma crise política particularmente severa, mas que ultrapassava os desacordos em torno da emancipação dos escravos. Se tal questão era um tema sempre intrincado, ela parece ter se tornado, em meados da década de 1880, expressão de fissuras muito mais abrangentes na política, nos partidos e nas instituições imperiais. Essas fissuras se materializaram em uma profunda cisão intra-elite que comprometia o funcionamento tradicional do sistema representativo imperial, marcado pela constante negociação entre os grupos políticos representados, por meio dos dois grandes partidos constitucionais, no Parlamento. $^{479}$

Não era descabido, nesse sentido, que os oposicionistas lançassem mão de duas acusações manifestamente paradoxais ao ministério Dantas. Ora de que o presidente do Conselho possuía um "pacto" com o "príncipe conspirador" para se manter no poder, ora de que seu governo se assentava nos interesses "movediços" e “incendiários" que anarquizavam o país. Ambas as acusações, tão frequentemente atiradas contra o gabinete liberal de 6 de junho partiam do mesmo princípio: o presidente do Conselho e seus aliados rompiam com a boa prática parlamentar, procurando fora das instâncias representativas 
legítimas o apoio de que precisavam para dar seguimento a suas ambições.

Não havia nada de muito novo nas acusações contra a intervenção indevida do "poder pessoal" na condução dos negócios públicos; uma vez que tais acusações, ao longo do Segundo Reinado, haviam sido frequentemente disparadas contra São Cristóvão por parte daqueles que se encontravam na oposição parlamentar, a não ser talvez que se atente à mudança de ênfase em tais acusações: desta vez, arguia-se com frequência, era o presidente do Conselho que usava a Coroa e colocava-a em situação vulnerável, para dizer o mínimo, em seu desejo irrefreável de impor ditatorialmente ao país seu projeto, e não o contrário. As recriminações dirigidas a essa suposta ambição de Dantas em promover seu próprio "poder pessoal", governando ditatorialmente, estavam diretamente ligadas ao fato de que o presidente do Conselho havia conseguido da Coroa um compromisso de dissolver a Câmara dos Deputados, caso fosse negada ao ministério confiança nos termos do projeto de emancipação. Para muitos parlamentares, isto significou obrigar o Poder Moderador a abandonar sua neutralidade constitucional e se comprometer com uma bandeira políticopartidária, o que estava fora da sua alçada. ${ }^{480}$

Deste modo, o chefe do governo, recriminavam seus adversários, colocava a política imperial de pernas para o ar, rejeitando deixar o cargo após ficar evidente, mais de uma vez, não poder contar com o apoio da maioria da Câmara. Se não era o Parlamento, hostil, nem a Coroa, "iludida", que o sustentavam, como então Dantas permanecia no poder, interrogavam retoricamente, como vimos, seus adversários. A resposta dizia respeito à segunda das acusações acima mencionadas: o senador baiano governava sustentado por interesses ilegítimos, que não se assentavam nos "elementos estáveis" do país, mas na "propaganda artificial" dos "radicais" ligados ao abolicionismo.

Nesse sentido, havia claramente, entre seus adversários, a percepção de que o ministério Dantas representava uma inflexão considerável na política imperial. De fato, era, parece ser seguro afirmar, a expressão na alta política de uma profunda inflexão que se operava no país, mas que começara fora do Parlamento.

O novo sistema eleitoral, direto e distrital, com um corpo de eleitores mais heterogêneo e competição mais acirrada entre os candidatos, possibilitou que o pleito de dezembro de 1884 fosse algo próximo a um plebiscito sobre a política ministerial e seu

480 Atas do Conselho de Estado Pleno. Terceiro Conselho de Estado. Sessão de 29/07/1884. ACD. Sessões de 1884 e 1885; AS. Sessão de 1885. 
projeto emancipacionista. ${ }^{481}$ Causou, também, prejuízos graves à disciplina partidária e transformações, que ainda devem ser mais profundamente investigadas, na economia interna dos partidos políticos. ${ }^{482}$ Com os elementos de popularização da política presentes já desde o início da década, as eleições serviram para atirar de volta às ruas, aos comícios, meetings, aos jornais e manifestações populares menos "respeitáveis", a questão servil. Desta forma, o monopólio decisório parlamentar, marcado pela negociação e compromisso entre os partidos, ficou profundamente ameaçado, no momento em que se encontrava em jogo o decisivo tema da escravidão. Não parece ter outro sentido a recusa da oposição em encetar a discussão do projeto e utilizar de todos os recursos disponíveis naquele momento, como o "terceiro escrutínio" do reconhecimento de diplomas de deputados e as emboscadas das seguidas questões de confiança, para feri-lo de morte no nascedouro. Um projeto que passasse pelo crivo de forças extraparlamentares não deveria ser legitimado politicamente. Mais ainda, uma clara vitória ministerial no pleito, mesmo que numericamente pequena, garantiria grande força moral ao governo, conferindo-lhe a possibilidade, de impacto nada desprezível na batalha discursiva da política, de argumentar que a nação, representada no Parlamento, aprovava em sua maioria um projeto que libertava escravos sem indenização, concedia terra a libertos e, ao exigir declaração de naturalidade na matrícula programada, cercava de dúvidas a legalidade do "estado servil" de uma gigantesca porção dos cativos existentes no Império, representando para a própria existência da instituição um risco potencial sem precedentes.

A solução aventada para conter a avalanche, como indicara João Alfredo, seria a tentativa de um novo compromisso entre os partidos constitucionais, ou ao menos suas alas moderadas e dispostas à transação. O escolhido para chefiar a nova organização ministerial foi Saraiva, de quem se esperava que utilizasse seu prestígio e experiência para alcançar um acordo suprapartidário que tirasse o país da crise. Desta vez, tal compromisso não deveria ter como objetivo apenas aplacar a interferência do monarca no processo decisório do Parlamento, mas também das forças políticas radicalizadas, à frente o abolicionismo militante.

\section{3 - De Saraiva a Cotegipe: um compromisso efêmero (1885)}

481 Angela Alonso já afirmou que “[...] as eleições de 1884 eram um plebiscito sobre a abolição”. Cf. Angela Alonso, Joaquim Nabuco: os salões e as ruas, p. 187. 482 Cf. Guo-Ping Mao, op. cit. 
A experiência, pois, demonstra que há situações em que os dois partidos devem fazer um armistício para solução de questões graves; que há situações em que os dois partidos devem conjuntamente tratar de semelhantes questões, para que elas sejam bem resolvidas.

Tenho, portanto, razão para julgar, não só que a solução da questão impõe-se, mas também de entender que convém cooperem assim liberais, como conservadores, abolicionistas radicais e moderados não abolicionistas. (Apoiados e apartes.) ${ }^{483}$

Nesses termos, Saraiva iniciava sua curta jornada ocupando a presidência do Conselho de Ministros pela segunda vez, cuja recepção ministério foi fria em ambas as casas do Parlamento. Entre a hostilidade de importante parcela do Partido Liberal e o alívio menos triunfal do que pragmático da antiga dissidência e da maioria do Partido Conservador, adentrou o edifício da Câmara o novo chefe de governo, que pretendia "conciliar" os partidos. Antes do pronunciamento do presidente do Conselho, uma das figuras mais importantes dentre os antigos liberais dissidentes, o representante de Alagoas Lourenço de Albuquerque, resumiu os motivos que lhe faziam confiar no novo chefe de gabinete, em termos similares àqueles que Saraiva, pouco depois, expôs à Câmara:

[...] o atual ministério quer e deve resolver a questão do elemento servil, porque outra não é sua missão.

Compreendendo o ministério que se trata de uma questão social, julgo poder afirmar que seu projeto não será apresentado com caráter de questão de partido (apoiados), não será imposição, será questão livre (apoiados); e é muito louvável da parte do gabinete reconhecer que o parlamento vale alguma coisa, e que o seu concurso pode ser muito eficaz para a lei que todos desejamos seja a mais conveniente possível.

(Apoiados e trocam-se muitos apartes. O Sr. Presidente reclama atenção). ${ }^{484}$

Se dependesse de muitos dos antigos aliados de Dantas, no entanto, as armas continuariam em punho. No Senado, Silveira da Mota e José Bonifácio fizeram questão de recordar ao novo presidente do Conselho que sua ascensão ao poder era mal explicada. Que motivos, além das exigências dos conservadores e do patrocínio oculto da Coroa, havia para que um estadista que sempre escondera suas opiniões acerca da questão servil passasse à condição de salvador do país quando esta ganhava uma gravidade sem precedentes? Onde estavam as credenciais emancipacionistas de Saraiva, aquele mesmo que jamais "cogitara" abordar tal questão? Se pretendia o chefe de gabinete "afirmar que

483 ACD. 11/05/1885, p. 34.

484 Ibid., p. 24. 
não teve acordo algum com os conservadores, nem pacto com a coroa", interpelou Silveira da Mota, "então o que houve, quando ninguém sabe, nem soube, o que S. Ex. quer a respeito do elemento servil?" ${ }^{485}$ Incisivo, José Bonifácio, por sua vez, dissecou o ministério e criticou sua ascensão e composição supostamente arbitrárias, declarando observar com estranheza o apoio dos conservadores a Saraiva. A seu ver, o gabinete não era "constitucional, mas sim um ministério de camaradagem". Deste modo, o senador paulista não o apoiaria, pois, diferentemente do seu antecessor, que "queria caminhar", o novo presidente do Conselho e seus aliados caminhavam "retrogradando". 486

Ainda mais ácidas foram as observações da imprensa simpática ao abolicionismo. A Gazeta de Notícias fez um amplo editorial investindo contra o governo que se formava e emitindo, ainda, alertas que se provariam parcialmente proféticos nos meses seguintes. Os interesses ocultos dos conservadores em apoiar maciçamente Saraiva foram tratados pausadamente pela folha, que os acusava de, utilizando o discurso da conciliação e compromisso entre os partidos, esperarem pela melhor oportunidade para voltar ao governo, derrotar os adversários e impor sua própria agenda para a questão servil:

Compreende-se que os conservadores não clamavam pelo Sr. Saraiva só pelo prazer de ver a respeitável pessoa de S. Ex. sentar-se em uma cadeira de ministro e decidir a questão do elemento servil. Os conservadores sabem como está constituída a câmara; sabem que meia dúzia de dissidentes liberais bastam para dar-lhes número a eles para porem o Sr. Saraiva em minoria; sabem que é difícil a qualquer governo entender-se com esta câmara, em que há deputados que derrubam um ministério por causa de uma vaia dada por uns maltrapilhos, e deputados que votam contra um projeto que assinaram.

Sabem isto tudo os conservadores, e esperam que, em prazo breve, o Sr. Saraiva achar-se-á em minoria, terá talvez de dissolver a câmara e dirigir uma das tais eleições honestas que o tornam precioso aos olhos dos adversários.

Dir-se-á que, se os conservadores subirem assim, sobem parlamentarmente; é certo, pelo menos na aparência, porque a verdade é que a trica eleitoral está na massa do sangue dos nossos homens políticos, e a honesta abstenção do Sr. Saraiva não encontrará pendant da parte dos adversários em honesta abstenção de promessas. ${ }^{487}$

Se havia algum ponto positivo nessa situação, ele decorria, para a Gazeta, do fato de provar não ser mais possível que um gabinete se apresentasse ao país sem privilegiar a resolução da questão servil. E todo o mérito desse novo tempo na política nacional, em que

\footnotetext{
485 As citações referentes à apresentação do ministério 6 de maio ao Senado foram retiradas dos resumos contidos na seção "Diário das Câmaras" da Gazeta de Notícias. 12/05/1885, p. 2.

486 Ibid., p. 2

487 Gazeta de Notícias. 11/05/1885, p. 1.
} 
tornara-se impossível que ocupassem a presidência do Conselho um Martinho Campos ou um Paulino de Souza, pertencia a Manuel Pinto de Souza Dantas e seu "revolucionário" ministério de 6 de junho. ${ }^{488}$ A sombra de Dantas continuava, portanto, pairando sobre a política nacional e servia de referência àqueles que não podiam enxergar qualquer vantagem para a resolução da questão servil por meio de amplas concessões à oposição conservadora.

O exemplo de Dantas também era referência para Saraiva e seus aliados, mas pelo viés oposto, de seu fracasso por ter promovido a polarização do país. Mais do que realizar concessões ao Partido Conservador, Saraiva explicou sua ascensão ministerial pela necessidade de se recuperar o papel preeminente do Parlamento no encaminhamento da política nacional, defendendo sua prerrogativa exclusiva na resolução definitiva da questão servil. Sua urgência, confessava Saraiva, era até mesmo secundária, frente à necessidade de se devolver à representação nacional o que era seu de direito:

O atual governo põe de lado toda e qualquer questiúncula, que certamente não é própria da sua dignidade e da dignidade de outro qualquer governo, para só respeitar o sistema parlamentar, e sacrificará mesmo a questão servil por algum tempo ao triunfo do governo parlamentar, porque só o parlamento é que pode e há de resolver a questão servil.

O Sr. Fernandes da Cunha: - Ora, graças a Deus. ${ }^{489}$

"Se os dois partidos brigarem, e entrarem em conflito sério para a solução desta questão [servil]”, alertava mais adiante Saraiva, apelando a uma retórica humanitária, "a única vítima é o infeliz escravo". ${ }^{490}$ Deste modo, o recém-empossado presidente do Conselho apelava à conciliação dos partidos para que, dentro da ordem e atentando a todos os interesses sociais, se retirasse de uma vez por todas o país do impasse político em que se encontrava, obtendo-se uma solução definitiva à emancipação gradual dos escravos.

A própria composição ministerial era fruto evidente de tal esforço conciliador. Ao lado de Saraiva, que ocupava a chefia do gabinete e a pasta da Fazenda, encontrava-se um de seus mais próximos aliados no Partido Liberal, o visconde de Paranaguá, que, como vimos, se antes sustentara Dantas, agora respondia pelos Negócios Estrangeiros. Na Guerra e na Agricultura, estavam dois outros antigos aliados de Dantas, os deputados Antônio

\footnotetext{
488 Ibid., p. 1

489 Gazeta de Notícias. 12/05/1885, p. 2. O aparte do conservador baiano Fernandes da Cunha ilustra bem aquele alívio pragmático, referido mais acima, com que foi recebido o novo gabinete pela oposição. 490 Ibid., p. 2.
} 
Eleutério de Camargo, do Rio Grande do Sul, e João Ferreira de Moura, da Bahia. Menos simpáticos a Dantas eram o ministro da Marinha, Luís Filipe de Sousa Leão, senador por Pernambuco e, especialmente, o ministro da Justiça, o mineiro Afonso Pena, considerado por José Bonifácio o "fiscal da dissidência" no ministério. ${ }^{491}$ Completava o ministério ainda, na pasta do Império, João Florentino Meira de Vasconcelos, senador pela Paraíba. ${ }^{492}$ Ombro a ombro, antigos aliados e opositores de Dantas tentavam, da "Tebas governamental", dar o exemplo de união em torno de uma causa que deveria ser resolvida pelo concurso de todos.

Para além da composição ministerial, a própria apresentação do novo projeto emancipacionista foi tratada como um chamado ao compromisso. Apresentada como "questão aberta" por Saraiva, não apenas a proposta continha profundas diferenças se comparada com aquela defendida por Dantas, como, ademais, o novo presidente do Conselho declarou não fazer questão de nenhum de seus pontos, deixando aos representantes imediatos da nação, de todas as cores partidárias, o direito de alterá-la e emendá-la livremente.

A comissão formada para este fim tinha, em sua composição, tais elementos conciliadores. Para ela, foram nomeados deputados que haviam apoiado integralmente o ministério Dantas, os liberais André Fleury, Franklin Dória, Ulisses Viana, Francisco Maciel e Francisco Prisco Paraíso, ${ }^{493}$ o antigo dissidente Lourenço de Albuquerque, representante de Alagoas, bem como as duas principais lideranças do Partido Conservador na Câmara e adversários ferozes de Dantas, Andrade Figueira e Antônio Prado, representantes, respectivamente, de Rio de Janeiro e São Paulo, além do republicano paulista Prudente de Morais. ${ }^{494}$ Antes de adentrarmos nos debates, é importante tratar mais pausadamente do novo projeto de emancipação. ${ }^{495}$

Além de garantir que, após sua "libertação", os escravos maiores de 60 anos prestariam serviço por três anos ou até completarem 65 anos, o projeto previa ainda que os libertos idosos se manteriam obrigatoriamente em companhia de seus senhores. Tal

491 Ibid., p. 2.

492 Cf. Barão de Javari, op. cit., pp. 217-218.

493 Representantes de Goiás, Piaú, Pernambuco, Rio Grande do Sul e Bahia, respectivamente.

494 ACD. 12/05/1885, p. 55. O parecer da comissão sobre o projeto encontra-se na íntegra em ACD. 19/05/1885, pp. 247-249. Criticando, entre outros pontos, a libertação sem indenização pecuniária dos escravos sexagenários e defendendo que os cativos que contassem entre 60 e 65 anos deveriam ser incluídos na tabela que fixava os valores dos escravos, enquanto os maiores de 65 anos deveriam passar por arbitramento que definisse seu preço, Antônio Prado deu voto em separado ao da comissão, que se encontra em Ibid., pp. 249-251.

$495 \mathrm{O}$ texto original do projeto se encontra, integralmente, em ACD. 12/05/1885, pp. 53-55. 
disposição era extremamente simbólica, pois garantia que o domínio senhorial não seria rompido abruptamente, cedendo, por meio de um discurso humanitário, à lógica da tutela privada dos senhores sobre seus antigos escravos, que alegava-se não estarem preparados para o exercício da liberdade plena. ${ }^{496}$ Outra alteração significativa dizia respeito às disposições sobre concessões de terras a libertos. As colônias planejadas pelo projeto Dantas ofereciam condições para que, num futuro não muito distante, libertos pudessem se tornar proprietários de lotes de terra. Já o novo projeto previa "colônias agrícolas, regidas com disciplina militar" destinadas à internação de libertos "ociosos". Outro golpe foi a eliminação da declaração de naturalidade dos escravos a serem matriculados, o que, de acordo com Angela Alonso, era uma "revogação branca da lei de 1831, pois legalizava a propriedade de africanos contrabandeados entre 1831 e 1850 e sua descendência, que poderiam ser declarados como de 'filiação desconhecida'." A autora relata, ainda, outras transformações que afastavam o projeto Saraiva de qualquer espírito propriamente abolicionista:

A terceira tromba d'água recaiu sobre a indenização. Os velhos escravos que Dantas não indenizava, Saraiva passou a indenizar e bem. Nominalmente oferecia 50\% do valor do escravo, mas a tabela de depreciação do preço da escravaria por faixa etária (Lei 3270, artigo 1, parágrafo 3) inflacionava os preços de mercado [...]. O projeto Dantas teria impacto imediato na escravidão e asfixiaria seu mercado, com depreciação progressiva em 16 anos. Saraiva, à primeira vista, apressava para 12 anos, mas, de fato, aquecia o mercado, ao elevar os preços e mantê-los altos na curva de depreciação. Já o imposto que financiava o Fundo de Emancipação foi parcialmente desviado para subvencionar imigração. Tudo a vigorar depois de matrícula geral, agendada para dali a um ano. ${ }^{497}$

O toque final no caráter já reativo do projeto foi a disposição repressiva à fuga de escravos. Previa-se que aqueles que incitassem fugas ou acoitassem cativos fugidos

496 Segundo Joseli Mendonça, op. cit., objetivava-se manter a lógica da tutela e do gradualismo, na medida do possível, como referências fundamentais no processo de emancipação.

497 Cf. Angela Alonso, Flores, Votos e Balas, pp. 266-267. Sobre o novo imposto para financiar o fundo de emancipação, na verdade uma sobretaxa sobre todos os impostos gerais já existentes, exceto o que incidia sobre as exportações, afirma Robert Conrad: "O Projeto Dantas teria imposto uma sobretaxa para o benefício principalmente dos escravos, mas segundo os termos do Projeto Saraiva aqueles que mais ganhariam com essa sobretaxa seriam os donos dos escravos". O motivo disto estava na divisão dos valores arrecadados por meio da sobretaxa, presente no texto final da lei. A receita seria dividida em três partes iguais, "[u]m terço seria usado para libertar os escravos mais idosos e menos valiosos (os que já estivessem perto dos sessenta anos de idade), um terço seria usado para libertar escravos cujos donos se convertessem completamente para o trabalho livre (em troca de títulos e mais cinco anos de trabalho forçado) e o último terço seria usado para importar colonos para trabalhar nas fazendas". Cf. Robert Conrad, op. cit., p. 271. A adição desta última disposição, concernente ao incentivo à imigração, que não aparecia no projeto original, foi feita por influência do voto em separado de Antônio Prado. ACD. 19/05/1885, pp. 49-51. 
pagariam multas que variavam entre quinhentos mil e um conto de réis. Na letra final do projeto, se a multa foi reduzida para uma quantia que variava entre cinco e vinte por cento do valor total do escravo ajudado, aqueles condenados por auxiliar cativos estariam também sujeitos a punição de até dois anos de prisão. ${ }^{498}$ Não à toa, portanto, o projeto foi alcunhado de "capitulação escravista" por próceres do movimento abolicionista. ${ }^{499}$

Dentro do Parlamento, antigos aliados de Dantas, por sua vez, não cansavam de recordar ao governo a inadequação da posição em que se encontrava, sendo majoritariamente sustentado pelos conservadores da Câmara. ${ }^{500}$ De fato, a casa temporária do Parlamento parecia estar mais dividida do que sugeria um olhar que levasse em conta apenas a votação da $3^{\mathrm{a}}$ discussão do projeto. Tendo em vista que somente 17 deputados, majoritariamente liberais abolicionistas e alguns parlamentares da ala mais dura do Partido Conservador, se declararam contrários à proposta, enquanto mais de 70 a aprovaram, poderia parecer que Saraiva controlava, ou ao menos contava com o apoio, da ampla maioria dos deputados, inclusive liberais. ${ }^{501}$ No entanto, se ampliamos o escopo de observação e acrescentamos outras votações do mesmo período, referentes ao reconhecimento de deputados cujas eleições fossem contestadas e às diversas fases de discussão dos diferentes artigos do projeto, se torna duvidosa a existência de uma maioria sólida. ${ }^{502}$ Nestes casos, pode-se entrever, pelo contrário, a manutenção da proximidade entre a antiga dissidência e os conservadores, enquanto a base dantista se mantinha muito

498 Cf. Robert Conrad, op. cit., p. 271.

499 A expressão foi cunhada por Rui Barbosa. Cf. Robert Conrad, op. cit, p.270.

500 Parlamentares liberais em oposição a Saraiva acusaram constantemente o presidente do Conselho de firmar acordo tácito com Antônio Prado, líder dos conservadores na Câmara, nos ajustes pelos quais passou o projeto, levando mais em conta o voto em separado do deputado conservador paulista do que as aspirações da maioria de seus correligionários. Entre as mudanças importantes por que passou o projeto original até sua transformação em lei, esteve, por exemplo, a pena de prisão aos acoitadores de escravos. Além disso, como aponta Angela Alonso, Flores, Votos e Balas, pp. 266-267, na versão final da lei encontrou-se um meio de indenizar pecuniariamente os proprietários dos escravos sexagenários, que originalmente teriam direito apenas à prestação de serviços. O projeto original encontra-se em ACD. 12/05/1885, pp. 53-55. O parecer da comissão e o voto em separado de Prado encontram-se em ACD. 19/05/1885, pp. 247-251. A votação da redação final do projeto na Câmara, já sob o ministério Cotegipe, ocorreu em ACD. 25/08/1885.

501 ACD. 13/08/1885, p. 553.

502 Analisando somente a participação na votação da $3^{\text {a }}$ discussão, Sérgio Ferraz apresenta conclusões bastante interessantes. Em primeiro lugar, destaca o autor, o número de conservadores e liberais que votaram pelo projeto foi quase idêntico, 35 e 38 deputados, respectivamente. Dos então presentes no plenário, $81,3 \%$ dos conservadores e $80,8 \%$ dos liberais se mostraram, portanto, favoráveis ao projeto. Contudo, se se coloca em perspectiva o número de parlamentares ausentes no dia da votação, considerando o fato de não terem se apresentado para votar como abstenção, esses números ganham outra proporção. Constata-se, ao se adotar tal expediente, que, dos pouco mais de 65 liberais que compunham a bancada do partido na câmara temporária, cerca de 30 não sufragaram o projeto Saraiva. Cf. Sérgio Eduardo Ferraz, op. cit., pp. 195-196. 
mais recalcitrante às diretivas do gabinete. ${ }^{503}$

No caso do reconhecimento de deputados, foi flagrante a manutenção da coligação entre os antigos opositores de Dantas. Os deputados dissidentes do Ceará, Alagoas e Minas Gerais parecem ter votado consistentemente pelo reconhecimento de diplomas de conservadores, enquanto o núcleo liberal dantista parece ter mantido considerável unidade na tentativa de impedir o reconhecimento de deputados do partido adversário e, até mesmo, de ex-dissidentes, como o representante do Ceará Leandro Ratisbona, cuja eleição foi questionada por José Mariano, que apontou irregularidades no pleito. Ratisbona acabou reconhecido por 52 deputados, em sua maioria conservadores, secundados por exdissidentes como Lourenço de Albuquerque, Sinimbu Júnior e José Pompeu, contra 49 votos quase unanimemente liberais. ${ }^{504} \mathrm{O}$ padrão já havia se manifestado semanas antes, quando Joaquim Nabuco se tornou o mais ilustre prejudicado por essa situação insólita. Com eleição contestada pelos adversários, o liberal abolicionista pernambucano foi "degolado" por uma aliança entre conservadores e ex-dissidentes no mesmo dia em que Saraiva apresentou seu projeto de emancipação. ${ }^{505} \mathrm{O}$ conservador Manuel Machado do Nascimento Portela, contendor de Nabuco, foi reconhecido deputado pelo $1^{\circ}$ distrito de Pernambuco por 51 votos favoráveis a 48 contrários. Pesaram a balança a favor de Portela os próceres da dissidência anti-Dantas, José Pompeu, Lourenço de Albuquerque, Sinimbu Júnior, Benedito Valadares, João Penido e Felício dos Santos. ${ }^{506}$

A derrota de Nabuco, após sua eleição por voto popular, não deixou de causar revolta. Folhas da Corte simpáticas ao abolicionismo sugeriram que, entre as contrapartidas ao apoio do Partido Conservador e da antiga dissidência ao ministério Saraiva estava a derrota de alguns deputados liberais particularmente "incômodos", como o baiano Aristides Spinola e o próprio Joaquim Nabuco. A Gazeta de Notícias não deixou de ironizar: "todas estas degolações são uma homenagem do Sr. Saraiva à Lei eleitoral e ao partido conservador". Na capital pernambucana, onde ficava o $1^{\circ}$ distrito de Pernambuco, a reação à "degola" de Nabuco foi de pronta rebelião popular, sendo que a sede do jornal conservador $O$ Tempo, de propriedade de João Alfredo, chegou a ser atacada. ${ }^{507}$

503 ACD. Maio a agosto de 1885.

504 Gazeta de Notícias. 26/05/1885, p. 2. A exceção foram os republicanos paulistas, cujo procedimento foi aparentemente inconstante, ora apoiando um, ora apoiando outro lado.

505 Cf. Angela Alonso, Joaquim Nabuco: os salões e as ruas, pp. 195-196.

506 Gazeta de Notícias. 13/05/1885, p. 2. Representantes de Ceará, Alagoas e Minas Gerais, importa destacar novamente.

507 Cf. Angela Alonso, Joaquim Nabuco: os salões e as ruas, pp. 196-197. 
Se houve acordo para barrar Nabuco, ele não foi bem-sucedido por muito tempo. Pouco depois da derrota sofrida abriu-se uma vaga, por óbito, no $5^{\circ}$ distrito de Pernambuco. Os políticos liberais que se esperava que concorressem no novo pleito abriram mão de suas candidaturas e, sem grandes problemas, Joaquim Nabuco foi eleito, tomando assento no Parlamento semanas depois. ${ }^{508}$ A eleição do liberal abolicionista foi vivamente comemorada e seu reingresso na Câmara revigorou a oposição parlamentar ao ministério Saraiva.

Em um de seus primeiros discursos após tomar assento, Joaquim Nabuco não poupou o presidente do Conselho, afirmando que a nova proposta emancipacionista não fazia sentido no momento histórico pelo qual passava o país, em que até mesmo o projeto Dantas, mais adiantado, já se tornara insuficiente. A opinião antiescravista avançava rapidamente no Brasil, e no lugar de ajudar a liderá-la rumo à abolição da escravidão, Saraiva aliava-se à resistência, colocando o Partido Liberal contra a parede ao tentar comprometê-lo com um projeto que já não representava nada a não ser a tentativa de barrar o avanço da "generosa ideia". Quando Dantas subira ao poder, declarou Nabuco, "ninguém tinha coragem de chamar-se abolicionista. Descobriram o termo - emancipador - para obstar ao movimento da ideia". Mais de um ano depois, no entanto, o país se encontrava em outro contexto: "hoje, quem não é abolicionista?" ${ }^{509}$ Esses poucos que, erroneamente denominados liberais, agiam no Parlamento para tentar conter o inevitável, não representavam a autêntica vocação do partido:

[...] os votos que apoiam o presente projeto são a sua condenação. Uma lei de emancipação nesta época, para ser boa, devia ser uma lei imposta à resistência e não uma lei imposta ao movimento. (Apoiados, muito bem dos deputados abolicionistas.) Não é função do partido liberal tomar um lugar nessa junta de coice, descrita no Senado, e que o limpa-trilho da locomotiva tem que levar diante de si; não é missão do partido liberal galvanizar uma instituição, como a servil, uma instituição morta, e desempenhar a função tríplice, duas partes das quais eu já defini-a - de coveiro dos escravos de 60 anos e a do capitão do mato dos escravos fugidos, e as quais posso acrescentar a terceira, que as completa e a que resulta de todo este projeto: - a função de corretor de escravos.

[...]

Entendo que a missão do partido liberal é colocar-se à frente do movimento nacional, e não querer refreá-lo ou contê-lo. ${ }^{510}$

508 Ibid., p. 197.

509 ACD. 06/07/1885, pp. 209-210.

510 Ibid., p. 212. 
Dias antes, Nabuco já tomara a palavra para justificar a oposição dos liberais abolicionistas ao ministério Saraiva e seu projeto de reforma do "estado servil". ${ }^{511} \mathrm{O}$ silencioso "abandono", por parte de Saraiva, de seus correligionários que haviam sustentado o gabinete Dantas fora um golpe importante, segundo Nabuco, nas esperanças daqueles que desejavam colocar o Partido Liberal em seu lugar apropriado: junto à mais humanitária e urgente das reformas. Mais do que abandonar Dantas, enfatizou o deputado pernambucano, Saraiva subiu ao poder como representante de uma coalizão entre conservadores e dissidentes, o que tornava seu governo ainda menos digno de qualquer apoio dos setores abolicionistas mais avançados do Partido Liberal:

Não sou dos que felicitam ao nobre presidente do conselho pela quase unanimidade que o sustenta. Para consegui-la, S. Ex. teve que criar o governo de coalizão, sob que nós vivemos, constituindo essa situação liberal em situação conservadora, com um governo liberal responsável.

Para isto, foi preciso que S. Ex. fizesse o partido liberal, que já ia adiantando na marcha da grande reforma, voltar atrás não somente para receber a sua retaguarda distanciada, mas os auxiliares estrangeiros. ${ }^{512}$

O primeiro dos "auxiliares estrangeiros" no ramo temporário já expusera ao país a posição de seu partido. Antônio Prado substituíra Andrade Figueira na liderança da minoria conservadora na Câmara após o obstinado deputado fluminense se recusar a seguir o núcleo de seu partido na sustentação de Saraiva e seu projeto. Para o deputado paulista, que orou em nome da grande maioria de seus correligionários, o compromisso em apoiar o gabinete liberal então no poder resultava de uma profunda preocupação com a situação política e econômica do país. No chamado à moderação e ao diálogo entre os homens de Estado que fazia o presidente do Conselho, enxergava Prado, havia a única possibilidade real, naquele momento, de superação da crise que se instaurara após o governo de seu antecessor:

Sr. presidente, em fevereiro deste ano, quando presenciei nas principais ruas desta capital as cenas que aqui se deram, o que se passava diariamente nas proximidades e à porta deste edifício, e neste próprio recinto, o meu coração de brasileiro e de monarquista sentiu-se profundamente confrangido. (Apoiados)

Eu vinha, Sr. presidente, de uma província onde as lutas partidárias e eleitorais, por mais renhidas que sejam, não têm conseguido retardar, antes têm servido de estímulo ao seu progresso e desenvolvimento; aonde as questões, ainda as mais

511 ACD. 03/07/1885, pp. 150-161.

512 Ibid., p. 151. 
incandescentes, como esta do elemento servil, que se tem procurado resolver mais pela agitação das paixões, do que pelo estudo das conveniências sociais, se discutem nas lides da tribuna, da imprensa e nos comícios eleitorais. E, então, vendo o que se passava na capital do Império, perguntei muitas vezes a mim mesmo: é isto que se chama manifestação da opinião pública em um país civilizado? A esta opinião pública poderão estar confiados os destinos deste vasto Império?

Confesso, Sr. Presidente, que cheguei a acreditar que assistia aos últimos arrancos de agonia de nossas instituições.

Felizmente, Sr. presidente, a queda do ministério de 6 de junho, a chamada do honrado Sr. conselheiro Saraiva para organizar novo gabinete e a apresentação do seu programa bastaram para produzir uma transformação nesse estado de coisas verdadeiramente aflitivo.

Quando o nobre presidente do conselho apresentou-se nesta Câmara e manifestou o modo por que pretendia realizar a reforma do estado servil foi recebido com simpatia por ambos os lados da Câmara. Essa simpatia do lado conservador para com o nobre presidente do conselho tem-se aumentado à proporção que vão surgindo as dificuldades com que os intransigentes do seu partido procuram impedir-lhe o passo na execução do seu programa - de resolução prudente e pacífica da questão da emancipação.

É por isto, Sr. presidente, que o partido conservador deve prestar a S. Ex. o apoio de que necessita para a realização da reforma do estado servil. ${ }^{513}$

Encontrando-se o espírito público "agitado e ainda sob a influência fatal da política imprudente, que foi proclamada e seguida pelo ministério passado", mostrava-se necessária a intervenção do legislador "para assinalar o ponto em que se deve ficar nesta questão" da emancipação dos escravos. Deste modo, embora entendesse que "a lei de 28 de setembro [de 1871] por si só, por seus efeitos" podia resolver a questão, Prado prestava seu apoio ao governo e à nova medida apresentada, contanto que tivesse "por fim não só determinar o ponto de parada nesta questão, como assegurar aos possuidores de escravos" um prazo razoável para a transição ao novo regime de trabalho. ${ }^{514}$

Correligionário e comprovinciano de Antônio Prado, Delfino Cintra justificou em termos parecidos o apoio dos conservadores paulistas ao ministério e ao projeto emancipacionista, que respeitava "os dois princípios da escola conservadora - o processo gradual da libertação e a indenização". Não se filiando ao "partido abolicionista" como fizera seu antecessor, Saraiva demonstrava almejar "resolver a questão com a lavoura", dando "ao seu projeto feição conservadora" e colocando-se, desta feita, ao lado dos "interesses estáveis da sociedade". 515

Não obstante as declarações de apoio recebidas pelo presidente do Conselho, com a

513 ACD. 01/07/1885, pp. 86-87.

514 Ibid., p. 87.

515 ACD. 03/07/1885, pp. 146-147. 
circunspecção costumeira, muitos de seus contemporâneos não deixavam de reparar na posição crescentemente vulnerável em que o gabinete se encontrava. A inconsistência da base de apoio do governo foi fortemente destacada por um dos poucos deputados conservadores que, contrariando seu partido, mantinha-se infenso a qualquer concessão. Resistindo em ceder a uma medida que considerava inútil e perigosa ao processo de emancipação, Andrade Figueira manifestou sua rejeição ao ministério em termos também eminentemente políticos.

Para o deputado fluminense não havia justificativa na manutenção de Saraiva no poder, visto que era sustentado pelo partido adversário e não por seus próprios correligionários, entre os quais muitos rejeitavam o projeto de reforma do estado servil. Nesse sentido, para Figueira, mais correta seria a ascensão do Partido Conservador. Nem outro sentido tivera o "quer, pode e deve" de Cotegipe a não ser sinalizar aos conservadores que a resolução da questão servil deveria a eles caber. "[S]e fosse emancipador", declarou Andrade Figueira, "trataria de por para fora o nobre presidente do conselho". ${ }^{516}$ Explorando ironicamente as inconsistências do ministério, o representante do Rio de Janeiro chamou atenção para o fato de que quanto mais a base de apoio ao ministério se deslocava para o lado conservador, mais a desaprovação a Saraiva crescia nas fileiras liberais. Essa situação, nada parlamentar, gerava uma inversão perigosa dos partidos. "Querer”, admoestou Figueira, “em nome do partido liberal, com um grupo de 10 ou 12 votos, fazer uma reforma desta ordem, com o apoio do partido conservador, não é sério nem político". Enquanto atirava o partido conservador em uma "vereda perigosa", o presidente do Conselho era também responsável por "sofismar a missão do partido liberal":

[...] procurar fazer uma reforma destas em nome do partido liberal como realização do programa liberal, pois disse que deu seu mote - eleição livre e trabalho livre - com responsabilidade do partido conservador decaído, será tudo, mas seguramente não é parlamentar, segundo os princípios que regem nosso sistema de governo. ${ }^{517}$

Ora, um gabinete conservador que assumisse as rédeas do Poder Executivo contaria ao menos 53 votos na Câmara, calculou Andrade Figueira, enquanto o presidente do conselho estava "reduzido a 17 votos do seu partido". ${ }^{518}$ Quem estava mais preparado, então, para

516 ACD. 16/07/1885, p. 404.

517 Ibid., p. 405.

518 ACD. 18/07/1885, p. 467. 
ocupar o governo?

Andrade Figueira fazia tal inquirição em aparte durante discurso do antigo dissidente Lourenço de Albuquerque. O deputado alagoano subira ao palanque para defender uma política ministerial que, segundo ele, deveria consistir no compromisso entre os homens políticos prudentes dos dois partidos. Retomando o argumento de que aquele não era momento para divisão ou radicalização, mas para união entre os representantes da nação, Lourenço de Albuquerque declarou ser necessário que o governo procurasse, como fazia, sustentação nos moderados da Câmara. Vendo-se "colocado entre dois extremos: de um lado os que querem a emancipação instantânea e completa e de outro os que não querem que se vá uma linha além da lei de 28 de setembro", Saraiva precisava se apoiar no "centro da câmara"; nem conservadores emperrados, nem liberais extremados. ${ }^{519}$

O próprio presidente do conselho tentou se defender das acusações de que, apesar de ter abandonado o Partido Conservador décadas antes para engrossar as fileiras liberais, teria se mantido fiel às bandeiras da primeira agremiação. "De que sou acusado?”, inquiriu Saraiva retoricamente, respondendo logo em seguida: "de ter feito um projeto com feições conservadoras". Mas o que havia de errado em, quando se tinha em conta a segurança da lavoura e dos "interesses permanentes" do país, assumir-se uma postura conservadora?

Serei sempre o mesmo: liberal, quando quiser que a sociedade marche e marche como deve marchar, como por exemplo, acabando com a escravidão, que é realmente uma nódoa que temos de nossa civilização; conservador, quando quiser que essa extinção se faça de maneira que possamos acabar com a escravidão sem que as nossas rendas diminuam, sem que o liberto afinal fique inimigo de seu ex-senhor, porque é por isso que desejo que este projeto tenha feições conciliadoras. ${ }^{520}$

Diferentemente de 1881, lembravam constantemente alguns deputados liberais, esse espírito de conciliação manifestado por Saraiva não encontrava mais eco na realidade do país; eram outros os tempos. O ex-ministro da Guerra do gabinete Dantas, Cândido de Oliveira, fez um longo discurso dedicado, em parte, a explorar a lealdade e simpatia minguadas que dedicavam seus correligionários ao segundo ministério Saraiva. ${ }^{521}$ Indicando pertencer ao gabinete anterior a autêntica bandeira liberal, o deputado mineiro não fez questão de ser parcimonioso nas referências negativas à grande reforma promovida, até então, durante os mais de sete anos de seu partido na situação: a reforma eleitoral de 
1881 fora uma glória, mas já havia perdido muito de seu brilho.

Como a imensa maioria de seus correligionários, Cândido de Oliveira havia apoiado a reforma, apesar das inúmeras concessões realizadas pelo presidente do Conselho para que pudesse passar por um Senado majoritariamente conservador. Sufragara a lei, alegou o representante de Minas Gerais, por entender "que a maior preocupação do partido liberal devia ser obter a reforma direta". Sufragara-a também porque não era “imutável”, e agora, mais do que nunca, mostrava o quanto seu caráter restrito já a fazia defasada: não tinha o direito, "ante duas eleições sucessivas, de pedir retoques a lei?" O grande segredo da posição conservadora, em um país de "profundo sentimento democrático" como o Brasil, "em que as ideias liberais tão acentuadamente se encontram no espírito da população", observou o deputado, era a intrincada prova de renda, que mistificava o censo eleitoral baixo e impedia que grandes parcelas da população tivessem acesso aos direitos políticos que lhes cabiam:

Removida da tela do debate esta questão incandescente do elemento servil, resolvida ela de qualquer modo, porque a solução há de dar-se, o grande programa do partido liberal será o de alargar o sufrágio, de modo que a vontade nacional seja devidamente consultada e representada. (Apoiados e apartes.) ${ }^{522}$

Cândido de Oliveira, em consonância com outros liberais, fazia uma proposição clara: o Parlamento, que, graças a uma lei eleitoral cujo liberalismo havia sido fortemente restringido por seus adversários, estava eivado de sentimentos conservadores, era incapaz de representar genuinamente a vontade popular, daí os danos que "dez ou doze díscolos" do Partido Liberal eram capazes de causar ao cerrar fileiras com os adversários, sobrerepresentados na Câmara dos Deputados. A solução para isso seria a extensão do sufrágio aos diversos setores da sociedade que se encontravam ilegitimamente excluídos do processo político formal. Mais imediatamente, por outro lado, as consequências desse estado de coisas haviam sido, em primeiro lugar, os obstáculos intransponíveis que encontrou o gabinete anterior ao não poder contar, no Parlamento, com o apoio que possuía fora do Parlamento e, em segundo lugar, a impossibilidade de o gabinete que ocupava então o poder governar sem apoio dos adversários conservadores. A resolução a tais discrepâncias só a podia encontrar o próprio Partido Liberal, que deveria abraçar sua vocação democrática, ampliando o acesso ao voto e transformando, de uma vez por todas, 
a câmara temporária na mais autêntica representação nacional.

A gravidade especialmente explosiva da situação de meados da década, contudo, indicava o deputado mineiro, era bastante mais intensa do que aquela encontrada no início do mesmo decênio. Isto porque, se a lei eleitoral, com voto direto e distritos uninominais, deixara as bases para seu próprio aprimoramento futuro, a questão servil apresentava dificuldades muito maiores, pois se pretendia que o projeto então apresentado fosse a palavra final no processo de emancipação, uma palavra que, pela fraqueza do governo, soava cada dia mais conservadora. Devendo "compreender que tem grande responsabilidade perante a história", o Partido Liberal não podia mais se dar ao luxo de "fazer coro comum com os adversários", permitindo que se infiltrassem "em um projeto que devia ser a glória para esta nação, as doutrinas reacionárias, os sentimentos de regresso" que se lhes impunham os conservadores e que era "a arca da aliança do novo gabinete com a oposição que o combatia". 523

As "doutrinas reacionárias" que influenciavam o projeto original, já francamente aquém do que esperavam não só liberais abolicionistas, como também outros mais moderados, advinham especialmente de emendas baseadas nas proposições do voto em separado de Antônio Prado. O significado dessas emendas ia além de seu caráter conservador; demonstrava nitidamente, segundo os discursos de muitos liberais, uma capitulação sem precedentes de um governo de seu partido aos desígnios dos adversários. $^{524}$

523 Ibid., p. 42.

$524 \mathrm{O}$ projeto original, por exemplo, previa uma redução anual de $6 \%$ no valor dos escravos, a começar da matrícula. Prado, por outro lado, declarava que, sendo tal medida "uma limitação do direito de propriedade", era necessário que a depreciação fosse mais vagarosa nos primeiros anos, "devendo crescer progressivamente na razão do encurtamento do prazo calculado" para o final da escravidão, $15 \mathrm{ou}$ 16 anos, segundo o projeto. $O$ deputado paulista propunha um prazo menor para a emancipação, 14 anos, mas a contrapartida era uma redução menor do valor da propriedade servil nos primeiros anos: tal redução atingiria os 6\% anuais apenas cinco anos depois da matrícula, mantendo-se nesse patamar até o $8^{\circ}$ ano e subindo gradativamente até o $14^{\circ}$ ano. No texto final da lei, aprovada em 28 de setembro de 1885 , o prazo para o final da escravidão foi reduzido para treze anos, mas a gradualidade proposta por Prado foi, com leves retoques, adotada. Outro ponto interessante foi a fixação do valor dos escravos por faixa etária. Na lei, o valor de todos os escravos menores de 30 anos seria de 900 mil-réis, enquanto poderiam chegar aos 50 anos valendo 600 mil-réis; no projeto original, os escravos maiores de 40 anos não poderiam valer mais do que 400 mil réis. Além disso, houve ainda a inclusão de medida que previa a utilização da terça parte dos recursos do fundo de emancipação para "subvencionar a colonização por meio do pagamento de transporte de colonos que forem efetivamente colocados em estabelecimentos agrícolas de qualquer natureza". Esta opção imigratória da lei ia de encontro às palavras do próprio Saraiva, que na apresentação de seu programa afirmara desejar privilegiar o braço nacional no processo de transformação do trabalho. Nunca é demais lembrar que foi Antônio Prado, na posição de ministro da Agricultura, quem assinou a chamada Lei dos Sexagenários, em 28 de setembro de 1885. ACD. Maio a setembro de 1885. Robert Conrad, op. cit.; Joseli M. N. Mendonça, op. cit. 
Foi em meio a esse contexto que Joaquim Nabuco subiu repetidamente à tribuna da Câmara. Em seus discursos, as críticas ao projeto se tornavam, por diversas vezes, secundárias, sendo o novo projeto de lei colocado na posição de mera expressão superficial de uma crise muito mais profunda pela qual passava o Partido Liberal. "Com efeito", recriminava o deputado pernambucano, o que se via então era "um governo liberal apoiado entusiasticamente pelos conservadores". Nas "mínimas questões”, o Partido Conservador levantava-se "quase inteiro para apoiar o honrado presidente do conselho". Essa "liga" que se formava entre governo liberal e deputados conservadores tinha um sentido manifesto, que era fazer da situação que nascera "dividida em dois partidos", fundir-se "em um molde" e para um fim, "o de fazer passar a lei". ${ }^{525}$ No entanto, os significados de tal conluio eram muito mais profundos e podiam ter consequências fatais para o sistema partidário do Império. Esse deslocamento do governo e de parcelas do Partido Liberal para um centro nebuloso poderia gerar uma significativa adesão dos setores mais radicalizados do partido, já não se sentindo representados, à república. Uma coisa era certa: a ala "democrática" do Partido Liberal não sustentaria o gabinete, caso os conservadores lhe retirassem o apoio no futuro. Profeticamente, Nabuco advertiu o presidente do Conselho:

Se o partido liberal estivesse no seu lugar, o partido conservador estaria votando contra ele. Para que o partido conservador esteja apoiando um gabinete liberal é preciso que esse gabinete tenha restringido as aspirações do seu partido, renunciando à sua missão de iniciador, e que esteja fazendo uma política que aos conservadores parece ser a melhor neste momento para demorar a marcha da ideia abolicionista no país... É preciso, por outras palavras, que o gabinete liberal seja um governo de combate e resistência. (Trocam-se diferentes apartes.)

$[\ldots]$

O partido conservador procede desta forma, não por amor da sorte dos escravos pela qual não mostrou simpatia alguma antes da eleição (não apoiados da bancada conservadora), não pela sorte da lavoura, porque faço ao partido conservador a justiça de acreditar que ele não pensa que esta lei venha a tranquilizar a lavoura (apoiados $e$ apartes).

Ele acompanha o honrado Sr. Saraiva provavelmente esperando, já que esta é a primeira vez na nossa história que um partido político faz o que chamam política larga, esperando que o sacrifício que fazem e o modo por que o fazem, lhe seja levado em conta no dia da distribuição. (Protestos e reclamações da bancada conservadora). ${ }^{526}$

O trecho citado leva-nos por dois caminhos. Primeiramente, havia o claro descontentamento com a política de coalizão praticada por Saraiva e o alerta às crescentes 
divisões que tal política gerava no seio do Partido Liberal. Em segundo lugar, havia as apreciações sobre os interesses e expectativas dos conservadores quanto a tal política. As próximas páginas serão dedicadas a tecer considerações sobre ambos os temas, trilhando, dentro das presentes limitações, os caminhos sugeridos por Joaquim Nabuco.

O alerta sobre o abandono da ala "democrática" do Partido Liberal por Saraiva parecia fazer parte também de uma disputa em torno da identidade da agremiação, iniciada com vigor durante os combates travados sob o governo de Dantas. Este, sobre quem se afirmava haver preservado as ideias de seu partido e, obstinadamente, guerreado por elas, deveria, para Nabuco, servir de exemplo a seu sucessor. Se, no lugar de se apoiar na resistência, Saraiva tivesse optado por se tornar chefe de um Partido Liberal "que fosse mais do que um partido liberal, uma vasta União Democrática", tornando-se assim um verdadeiro continuador da política de Dantas, o presidente do Conselho mereceria todo o apoio de seus correligionários. ${ }^{527}$ Mas a "política de coalizão" de Saraiva excluía os elementos de renovação do partido e condenava-o a definhar rumo à indistinção com relação a seus adversários. ${ }^{528}$ Entre esses elementos de renovação, destacavam-se os abolicionistas, que Nabuco declarava serem os "pulmões do partido liberal", "vivificadores do sangue" e "agitadores das ideias que devem dirigir-lhe a marcha". Eram eles, segundo o deputado pernambucano, que mostravam não se compor o Partido Liberal "somente de elementos senatoriais", de "uma oligarquia de famílias orçamentárias, de líquens políticos formando o nosso parasitismo oficial". Pelo contrário, sob influência do elemento abolicionista e democrático, o Partido Liberal demonstraria ser "uma grande massa viva, livre, independente, desinteressada", sendo sua principal função no Estado "fazê-lo mover-se e caminhar". ${ }^{529}$ Assumindo sua verdadeira essência, o partido poderia reformar as instituições, rompendo finalmente com a surdez oficial ao grito de 1869: "Reforma ou revolução". 530

Os termos dos discursos de Nabuco ecoavam por parte considerável da imprensa da Corte. Para a Gazeta de Notícias, a eleição do abolicionista pernambucano fora, por um lado, um protesto contra o Parlamento que, contrariando a lógica da "questão aberta", trancara suas portas "ao mais genuíno representante de uma das maneiras de resolver esse

527 ACD. 03/07/1885, p. 155.

528 Ibid., p. 154.

529 Ibid., pp. 158-159.

530 A expressão estava contida no programa do Partido Liberal publicado em fins da década de 1860. Cf. Américo Brasiliense de Almeida e Melo, op. cit. 
problema" servil, e, por outro, a demonstração de que, mesmo em distritos agrícolas, onde ainda se fazia extensivo uso do braço escravo, a ideia emancipadora angariava "prosélitos bastantes para se chegar a este resultado, de mandar ao parlamento um homem como o $\mathrm{Sr}$. Joaquim Nabuco, que tem a esse respeito ideias tão radicais". ${ }^{531}$ Segundo a folha, a presença do "exaltado" Nabuco no Parlamento "era uma necessidade vital de que não podia prescindir o partido [Liberal], sob pena de completar o esfacelamento para que ia lenta, mas continuadamente, caminhando". Se Dantas havia rejuvenescido o partido, "dando-lhe uma razão de ser", Joaquim Nabuco, "paladino dessa mesma ideia que o gabinete Dantas inscreveu em sua bandeira", poderia se tornar o núcleo de uma nova organização que se afastasse das "conveniências eleitorais e de personalidades". 532

O "rejuvenescimento" proposto pelo articulista significava reconhecer que o "velho programa da reforma ou revolução" havia sido abandonado pelos "velhos" e que, desprestigiado, não inspirava "confiança aos moços". ${ }^{533}$ Era necessário que "[h]omens novos com ideias novas", Joaquim Nabuco à frente, dessem continuidade ao movimento iniciado por Dantas. Essa nova organização, ainda embrionária, poderia contar, na Bahia, com talentos do quilate de Rui Barbosa, Rodolfo Dantas e Carneiro da Rocha, ministro da Agricultura sob o senador Dantas; em São Paulo, com José Bonifácio; em Minas Gerais, com Afonso Celso Jr.; no Rio Grande do Sul, com Francisco Maciel; em Pernambuco, ao lado de Nabuco, com José Mariano; entre outros. Esses políticos formavam um núcleo poderoso para o avanço da ideia democrática no país, no lugar de servirem a "um pequeno interesse partidário ou pessoal". 534

Não foi outro o sentido do discurso que Joaquim Nabuco proferiu poucas semanas depois na Câmara dos Deputados. Clamando não haver no Brasil nem governo representativo, nem "governo nacional", o liberal abolicionista avançou contra a baixa representatividade do sistema parlamentar do Império e clamou por mudanças que democratizassem e popularizassem o Partido Liberal. A ampliação do sufrágio eleitoral, a efetiva responsabilidade ministerial, a restrição da influência das lideranças oriundas do Senado vitalício nos partidos nacionais apareciam, então, como necessidades urgentes para

531 Gazeta de Notícias. 15/06/1885, p. 1. Ao contrário de sua candidatura anterior, pelo $1^{\circ}$ distrito de Pernambuco, localizado no Recife, Nabuco concorreu, com sucesso, pelo $5^{\circ}$ distrito da província, formado pelos municípios de Nazaré e Bom Jardim. Cf. Angela Alonso, Joaquim Nabuco: os salões e as ruas, p. 196.

532 Gazeta de Notícias. 15/06/1885, p. 1.

533 Gazeta de Notícias, 06/07/1885, p. 1.

534 Ibid., p. 1. 
se promover um governo inquestionavelmente livre e popular:

[...] em um país constituído desta forma, em que ninguém se sente forte e apoiado na opinião para resistir ao poder permanente e tradicional, somente a formação de partidos populares com força própria e disciplina poderia fazer nascer a responsabilidade ministerial e o governo livre. Mas para se poderem disciplinar os partidos, o partido liberal sobretudo, é preciso que se disciplinem pela liberdade (apoiados) e não pela vontade e imposição dos chefes. O partido liberal não se pode disciplinar pela escolha arbitrária de ministros; deve disciplinar-se pelo governo próprio (apoiados) porque um partido que não se governa a si mesmo não é digno de governar o país.

É por isso que eu protesto contra tudo que possa enfraquecer a organização democrática do partido liberal. ${ }^{535}$

Dantas também aparecia no discurso de Nabuco como um contraponto à "política larga" de Saraiva, que alegava tornar o Partido Liberal submisso a desígnios que não eram, ou não deveriam ser, os seus, cedendo aos adversários as rédeas do poder político no país. A Dantas, que não aceitara "diminuir" seu partido "com o intuito de receber votos de adversários", jamais "se figurou sequer a hipótese de viver um só dia do seu partido" quando se lhe faltasse o apoio deste. $\mathrm{O}$ chefe do ministério 6 de junho presidira um "governo liberal sustentado pelos liberais". 536

Nabuco, um dos próceres do "neo-liberalismo", 537 chegava, deste modo, ao Parlamento na posição não apenas de liderança abolicionista, mas também de paladino da renovação de seu partido em novas bases que incluíssem amplos setores da população arredados da política formal, construindo uma organização que lutasse pela democratização do Império, único meio de enfrentar a contraofensiva conservadora. $\mathrm{O}$ crescimento do prestígio desse grupo parecia ser resultado não só da "anarquia" que o advento do ministério Dantas causara no partido, ${ }^{538}$ mas também da posterior coalizão proposta por Saraiva a fim de garantir o "triunfo do governo parlamentar" frente às forças que se agitavam em todo o país em torno, especialmente, da explosiva questão servil. ${ }^{539}$ Esta situação, ao alienar um grande número de liberais mais avançados, permitiu que se ampliasse o espectro daqueles que defendiam abertamente uma ampla reorganização do partido e a adoção de um programa cujas ideias contemplassem a nova situação política do

535 ACD. 24/07/1885, pp. 132-133.

536 Ibid., pp. 132-133.

537 A expressão é do senador baiano Pedro Leão Veloso, em carta a Saraiva. AIHGB. DL 273.37, doc. 2, $28 / 12 / 1884$.

538 Mais uma vez, a expressão é de Pedro Leão Veloso. Ibid.

539 "Diário das Câmaras". Gazeta de Notícias. 12/05/1885, p. 2. 
país, mesmo que contrariando as lideranças tradicionais.

A preocupação demonstrada pelos "neo-liberais" se mostrava também pragmática, alertando, em vista da situação de crise cada vez mais clara pela qual passava o ministério Saraiva, para os danos ao Partido Liberal, ao processo de emancipação e ao edifício político do Império como um todo, especialmente frente a uma possível ascensão conservadora, quando da aprovação do projeto. Para José Mariano Carneiro da Cunha, por exemplo, o sistema eleitoral instituído em 1881 não garantira decisivamente o governo livre que deveria advir do voto livre, pois, além do restrito corpo eleitoral, as instituições imperiais e a organização dos partidos se mostravam um entrave à democratização do país e exigiam reformas profundas:

S. Ex. [Saraiva] não deu ao país o voto livre e a prova será dada quando presidir ao pleito eleitoral um governo que não tenha escrúpulos dos poderes de que a lei o não despojou. ${ }^{540} \mathrm{O}$ nobre presidente do conselho modificou o sistema de voto indireto para o direto, mas não concluiu a sua reforma. A coroa continua imperando em todas as relações sociais, o Senado ainda é vitalício e a Câmara dos Deputados continua a ser a Câmara de aspirantes ao Senado. Nestas condições, não se pode esperar dos homens públicos, a responsabilidade e a franqueza que devem ter para com a nação. ${ }^{541}$

A fraqueza de Saraiva e sua dependência em relação aos conservadores para governar colocavam-no, segundo o liberal pernambucano, numa situação precária. Nada garantia que, uma vez aprovado o projeto servil, os conservadores manteriam seu apoio ao governo. Diante de tal panorama, e com o Partido Liberal enfraquecido pelas profundas divisões que o dilaceravam, seria possível, indicava José Mariano, que não houvesse alternativa senão entregar aos adversários a presidência do Conselho, o que provavelmente encetaria a dissolução da Câmara e novas eleições. Neste caso, não seria surpreendente se o Partido Conservador, que não possuía "maioria no país", e cuja impopularidade se agravava "pela posição que assumiu na Câmara", se utilizasse de meios escusos para garantir uma maioria artificial no ramo temporário do Poder Legislativo:

Os pró-homens do partido conservador nem ocultam o pensamento que os leva a apoiar o gabinete. Será esse apoio dado no único intuito de concorrer para a solução de um problema social? Os atos e as palavras dos conservadores desmentem essa asserção. [...]

\footnotetext{
540 José Mariano provavelmente se referia à manutenção da influência de magistrados ligados ao centro na condução dos pleitos, delineada pelas emendas conservadoras ao projeto original de reforma eleitoral. Para o assunto, ver a $3^{\text {a }}$ sessão do capítulo anterior.
} 541 ACD. 07/08/1885, p. 388. 
Ou o nobre presidente do conselho está mistificando o partido conservador, ou deixa-se como criança, que ele o engane. Se S. Ex. tem com a Coroa algum pacto que não possa revelar à Câmara, se foi autorizado a prometer o poder ao partido conservador, escolheu mal a hora.

\section{$[\ldots]$}

Talvez breve o país veja como se arregimenta uma maioria fictícia, que represente o governo dominante, mas não a ideia vencedora.

São as consequências do governo de chapéu na mão e o nobre presidente do conselho ainda não tem cumprido a missão para que é chamado e já se apronta para sair. Não deve fazê-lo. ${ }^{542}$

Menos de duas semanas depois, Saraiva o fez. Após a passagem do projeto em $3^{\text {a }}$ discussão na Câmara dos Deputados, mas faltando ainda a aprovação de sua redação final, o presidente do Conselho convocou uma reunião ministerial em que consultou seus colegas sobre as possibilidades de manutenção do ministério no poder. Segundo o relato do já exministro da Agricultura, Ferreira de Moura, à Câmara dos Deputados, "a decisão unânime do conselho de ministros foi que o ministério não podia ter a esperança de reconstituir a antiga maioria liberal". Diante disto, foi acordado que "devia retirar-se já, sem mesmo esperar um voto de desconfiança". ${ }^{543}$ A situação anormal em que se encontrava a câmara baixa, em vista da coalizão encetada pelo gabinete na esperança de conseguir votos suficientes para a aprovação do projeto, impedia Saraiva, cuja iniciativa havia sido apoiada e combatida por setores de ambos os partidos, de indicar sucessor ao monarca, como era costume. ${ }^{544}$ Diante de tal situação, d. Pedro convocou para uma reunião os presidentes de ambas as casas do Parlamento, André Fleury, da Câmara dos Deputados, e o barão de Cotegipe, do Senado. Nesta primeira conferência, segundo relato da imprensa, “[o] Sr. Fleury recebeu de Sua Majestade a incumbência de comunicar ao Sr. Saraiva, que por sua ordem convidasse o sr. visconde de Paranaguá" a comparecer a São Cristóvão. ${ }^{545}$

Não obstante a ampla maioria do Partido Liberal ter revelado disposição em apoiar novo ministério para preservar a situação, o convite a Paranaguá pareceu a muitos uma tática da Coroa para liquidar o governo liberal. O motivo disto era simples: Paranaguá, na posição de ministro do gabinete Saraiva, não podia se afastar politicamente dos atos

542 Ibid., p. 388. Como veremos no capítulo seguinte, as eleições de 1886, sob gabinete conservador (Cotegipe), resultaram em uma esmagadora maioria deste partido, e foram repercutidas como um atentado contra a herança da reforma eleitoral.

543 ACD. 24/08/1885, pp. 5-6.

544 Ibid., p. 6. Segundo Ferreira de Moura, o presidente do Conselho ponderara ao Imperador "que eram especialíssimas as circunstâncias em que o ministério se tinha achado na câmara temporária, e que, sendo a sua retirada também determinada pela anormalidade dessas circunstâncias, julgava de seu dever absterse de qualquer conselho, que pudesse influir na deliberação que a coroa houvesse de tomar [...]". 545 Gazeta de Notícias. 19/08/1885, p. 1. 
daquele ministério, o que se constituía em obstáculo intransponível à arregimentação dos liberais desgarrados, não sendo possível, passada a questão servil, a formação de uma maioria liberal coesa capaz de apoiar um governo encabeçado pelo senador representante do Piauí. Além disso, muito foi dito sobre a recusa de Paranaguá em oferecer um nome alternativo ao monarca, o que pareceu a observadores uma rejeição dos próprios ministros ao possível governo de um "liberal mais liberal". 546

Muito ainda se especulou sobre as manifestações de bastidor dos conservadores no processo de transição ministerial. Alguns dias após a ascensão de Cotegipe, a Gazeta de Notícias dava conta do clima de mistério que ainda cercava o advento da nova situação política. ${ }^{547}$ Sabia-se, segundo o articulista, que André Fleury havia dito ao Imperador que um novo ministério liberal poderia contar com maioria do partido na Câmara para sustentálo. No entanto, completou, "ninguém sabe o que disse o chefe conservador, presidente do senado, para pender em favor de seu partido a balança imperial". Conforme indica a documentação, o procedimento de Cotegipe parece ter sido simples, pragmático e efetivo. Segundo as palavras do próprio André Fleury, após ter, em uma das conferências, garantido ao Imperador que "afastado o projeto de lei da extinção gradual do elemento servil, cessariam as divergências entre os liberais", o que possibilitaria que "se organizasse ministério com outro chefe liberal" sustentado pela maioria da Câmara, o barão de Cotegipe "declarou que não respondia pelo apoio de seus amigos", no caso de um novo gabinete liberal presidido por outra liderança daquele partido. ${ }^{548}$ As palavras do então presidente do Senado cortavam qualquer esperança de manutenção da situação por motivos que iam além das divisões entre seus adversários.

Quando Saraiva deixou o gabinete, seu projeto emancipacionista havia passado pela $3^{\text {a }}$ discussão na câmara temporária, mas sua aprovação ainda não estava totalmente garantida na casa, o que somente ocorreria quando a redação final fosse concluída e aprovada. ${ }^{549}$ Ainda mais, sua passagem pelo Senado seria provavelmente conturbada, e qualquer emenda ao projeto aprovada pelo ramo vitalício exigiria sua volta à Câmara dos Deputados, para nova apreciação. Pois bem, sem a garantia de maciço apoio conservador nas duas

546 Gazeta de Notícias. 24/08/1885, p. 1. O articulista lembrou de nomes como os de José Bonifácio e Afonso Celso que, mais adiantados que Saraiva, poderiam unificar o partido na Câmara, ou ao menos arregimentar número suficiente de liberais para constituir maioria.

547 Gazeta de Notícias. 31/08/1885, p. 1.

548 André Augusto de Pádua Fleury a José Antônio Saraiva. AIHGB. DL 274.18, 29/04/1888.

549 A votação após a finalização da $3^{\text {a }}$ discussão era considerada geralmente definitiva, mas alguns deputados liberais ameaçaram não aprovar a redação final em protesto contra a ascensão dos adversários. ACD. Agosto de 1885. 
casas do Parlamento, sendo que os conservadores detinham maioria no Senado e seus votos seriam necessários também para sua aprovação na Câmara, havia a possibilidade do naufrágio do projeto, com o comprometimento total da coalizão que precariamente o sustentava. Nesse sentido, as palavras proferidas por Cotegipe na conferência com o monarca constituíam uma possível alusão a uma barganha velada que acabou por lhe garantir a ascensão ao poder. O Imperador, por sua vez, parece ter anuído a tal alvitre, não procurando outra liderança liberal para chefiar novo gabinete além de Paranaguá que, membro do ministério Saraiva, não poderia praticar política adversa à do senador baiano. Não se afigura infundado observar, ainda, que os dois chefes liberais, ao não oferecerem ao monarca nome liberal para a sucessão, também não parecem ter se esforçado para a manutenção da situação, o que indicaria um acordo prévio entre o "messias de Pojuca" e o "pontífice máximo" da grei conservadora. Os interesses de Cotegipe na sua imediata ascensão ao poder estavam também ligados ao controle sobre a aplicação da lei. Neste ponto, como indica André Fleury, Saraiva parece ter sido iludido pelo aliado de ocasião. ${ }^{550}$

O novo ministério conservador de 20 de agosto de 1885 foi composto originalmente pelo barão de Cotegipe, na chefia e na pasta dos Negócios Estrangeiros, e por outro senador baiano, João José de Oliveira Junqueira, na pasta da Guerra; a pasta do Império foi ocupada pelo barão de Mamoré, senador pela província do Amazonas; na Fazenda e na Marinha, dois deputados fluminenses, Francisco Belisário Soares de Souza e Alfredo Rodrigues Fernandes Chaves, respectivamente; a Justiça ficou a cargo de Joaquim Delfino Ribeiro da Luz, senador por Minas Gerais; por fim, a Antônio Prado, o líder dos conservadores na Câmara e interlocutor direto de Saraiva no encaminhamento do projeto de reforma do elemento servil, foi entregue a pasta da Agricultura. ${ }^{551}$ A recepção do gabinete na Câmara acabou por unificar a maioria do Partido Liberal, que expressou veemente rejeição ao "falseamento do sistema representativo" que advinha da mudança de situação. Joaquim Nabuco, ${ }^{552}$ já antecipando algumas das proposições que se tornariam clássicas em panfletos escritos no ano seguinte, ${ }^{553}$ demonstrou sua indignação com palavras fortes:

550 André Augusto de Pádua Fleury a José Antônio Saraiva. AIHGB. DL 274.18, 29/04/1888. Como veremos, no capítulo seguinte, os regulamentos dos conservadores à Lei dos Sexagenários tirou muito de sua efetividade.

551 Cf. Barão de Javari, pp. 219-221.

552 ACD. 24/08/1885, pp. 25-33.

553 "O erro do Imperador" e "O eclipse do abolicionismo", in Evaldo Cabral de Mello (org.), Essencial Joaquim Nabuco, pp. 163-192. 
[...] em plena renovação social o Imperador nos faz voltar às formas atrasadas do governo pessoal, que ainda ontem se dizia extinto pela lei de 9 de janeiro de 1881 essa lei que fez presente de uma nação a uma oligarquia, - e envia a esta Câmara um ministério cada um de cujos membros, exceto o ilustre ministro da marinha, é um programa reacionário, e do qual nenhuma alquimia possível extrairia essa pedra filosofal do partido conservador: simpatia sincera, ou mesmo tolerância espontânea, para com as transformações democráticas do nosso tempo. ${ }^{554}$

O Partido Liberal, que se dividira graças à questão servil, ainda era o único capaz de guiar o país rumo a esse novo tempo em que o trabalho livre e o governo democrático seriam realidades. Essas divisões eram a prova de que o "espírito abolicionista" era um "espírito novo", uma "revolução nacional" que "não podia entrar em molde velho sem quebrá-lo". No lugar de perceber a gravidade da situação e promover ao poder aqueles que reuniam as condições para dar prosseguimento à renovação nacional pela qual se passava, democratizando de uma vez por todas o país, o Imperador escolhera auxiliar aqueles que já haviam se provado inimigos da liberdade:

[...] e hoje que os dez próximos anos, os últimos da escravidão, serão provavelmente também os últimos do reinado, nesse espaço de tempo que equivale ao antigo interregnum das monarquias eletivas, porque nas monarquias populares, a despeito de todas as constituições escritas, é então que se firma definitivamente o direito de sucessão, o Imperador, no meio da agitação abolicionista e no dia seguinte ao das eleições mais disputadas que já houve neste país, substitui o partido que se apresentou ao eleitorado em nome da liberdade, chamando a si o patrocínio dos escravos, pelo partido que não se propôs outra coisa neste parlamento senão ser o agente e o defensor da escravidão (apoiados e não apoiados; muitos apartes), e voltanos as costas, a nós que fomos acusados de ter feito um pacto com ele, no dia da derrota que devia ser comum e devia falar à lealdade de um poder que não pode deixar de ter consciência de que, sacrificando-nos pelo país e pelos escravos, estávamos servindo direta, ainda que desinteressadamente, à causa do único trono americano. ${\text { (Cruzam-se apartes. })^{555}}^{2}$

O deputado baiano César Zama, que apoiara Dantas e Saraiva, com quem tinha fortes laços políticos, por sua vez, poupou o Imperador das críticas, redirecionando-as ao sistema político do Império. ${ }^{556}$ As profundas divisões no Partido Liberal haviam sido, segundo Zama, decisivas para o desenrolar dos eventos. Enquanto não se desse atenção às questões

554 ACD. 24/08/1885, p. 26.

555 Ibid., p. 28. Entre as evidências oferecidas por Nabuco quanto às posições "escravocratas" do Partido Conservador, o deputado pernambucano citou a resistência de Cotegipe, em nome dos "todos os preconceitos da escravidão", à concessão de plenos direitos políticos aos libertos pretendida pelo primeiro gabinete Saraiva. Ibid., pp. 31-32.

556 ACD. 29/08/1885, pp. 69-74. 
de fundo que dificultavam o funcionamento regular do sistema parlamentar no país, não se poderia esperar composições políticas que genuinamente representassem a vontade nacional. O Senado vitalício, onde se concentrava demasiado poder nas mãos dos chefes que manejavam as formações ministeriais, o Conselho de Estado, com suas funções ambíguas e intervenção indevida nos negócios públicos, e o eleitorado reduzido, que não permitia que a lei de 1881 proporcionasse o resultado esperado, permaneciam como entraves à autenticidade da representação nacional e, portanto, dos gabinetes como sua imediata expressão. Uma renovação autêntica da política imperial só se produziria no dia em que a Câmara dos Deputados prevalecesse sobre todas as instituições, na condição de princípio, meio e fim das formações ministeriais. Para isso, era fundamental uma nova legislação eleitoral que complementasse a obra da Lei Saraiva, expandindo concretamente o direito ao voto. O Partido Liberal só recuperaria sua força e vitalidade quando o elemento popular tivesse participação real na escolha de seus representantes. Deste modo, Zama afirma ser preciso que

[...] o partido liberal de ora em diante não se limite simplesmente a fazer queixas estéreis dos defeitos das instituições. É preciso que se resolva decididamente a reformá-las, não esperando dos senadores e dos que se intitulam chefes, a iniciativa para essas reformas, mas metendo-se todos os liberais sinceros na empresa, de corpo, alma e coração.

Se quisermos ser partido liberal como entendo que devemos ser, é mister que na oposição tenhamos um programa, e este programa deve assentar sobre três pontos essenciais:

$1^{\circ}$ Alargamento do sufrágio, sendo a medida da capacidade do cidadão para o exercício do direito de voto a condição de saber ler e escrever;

$2^{\circ}$ A extinção do Conselho de Estado, como corporação prejudicial aos interesses públicos; e que muitas vezes encampa os excessos da Coroa e frequentemente encampa os ministros;

$3^{\circ}$ Reforma do Senado, no sentido da temporariedade, privando a Coroa do direito de escolha, equiparando-se o subsídio do senador ao do deputado, e devendo ser senador o candidato que maior votação tiver obtido nas urnas.

Esses três pontos são essenciais.

Se o partido espera conseguir tudo que lhe é mister, simplesmente com o regime da eleição direta está enganado. Esta prova de seis anos e tanto demonstra que a falta de liberdade do voto é causa concomitante e não eficiente. (Apartes.) ${ }^{557}$

Junto à bandeira crescentemente radicalizada da abolição da escravidão, as reformas propostas por Zama seriam intensamente defendidas por crescentes setores do Partido Liberal nos anos seguintes, geralmente sob a bandeira da "restauração do regime

557 Ibid., p. 73. Esses itens estariam presentes no derradeiro programa liberal lançado em 1889, que se encontra na íntegra em Elpídio de Mesquita, Dois Regimens, São Paulo: Typ. Leuzinger, 1896. 
democrático do Ato Adicional". ${ }^{558}$ Mais ou menos radicais, um número crescente de liberais começava a demonstrar, diante da derrota de uma solução liberal à emancipação dos escravos e do novo panorama político do país, mediante à crescente robustez da mobilização política extraparlamentar, uma recuperação das bandeiras tradicionais do partido, ressignificadas em meio a um contexto de intensa polarização política e conflagração social. O "regime democrático do Ato Adicional" tornava-se o código para um conjunto de reivindicações que iam da abolição da escravidão à expansão do sufrágio, passando pela autonomia provincial e pela renovação das instituições, com cerceamento das prerrogativas da Coroa e, até mesmo, organização em bases amplas, "populares", dos partidos.

Esse estado de coisas se tornou cada vez mais representativo de uma situação de crise interna profunda do Partido Liberal, e os pedidos pela renovação do partido, interrompidos com a derrota de Dantas, se tornaram mais insistentes e, gradativamente, mais impertinentes com relação às tradicionais lideranças partidárias. ${ }^{559} \mathrm{Em}$ simbiose com o abolicionismo, até pelo predomínio da questão servil na época e da consequente prevalência do movimento como representante por excelência da nova agenda democrática que se impunha ao Brasil, esse grupo de novos liberais elaborava, gradativamente, um projeto próprio para o país, que Nabuco resumia no tripé “Abolição, Federação e Paz" ${ }^{560} \mathrm{e}$ que outros, talvez um pouco mais moderados, chamavam, como vimos, simplesmente de "restauração do regime democrático", se referindo às reformas de 1830, mas incluindo em seu arcabouço a massificação do direito ao voto. Deste modo, se o Ato Adicional havia, originalmente, significado a prevalência de um pacto de tipo federativo, em que o preço da inclusão das elites provinciais no edifício político-institucional do Estado imperial foram os imensos obstáculos criados à realização de reformas sociais de longo alcance, ${ }^{561}$ na década final do Império, com a realidade sensível da popularização da política, a experiência daquele Ato passava a ser lembrada, ressignificada e radicalizada por amplos setores do Partido Liberal, que se encaravam como seus herdeiros, no intento de se conseguir "reformas democráticas".

\footnotetext{
$558 \mathrm{O}$ termo apareceria em discursos diversos de liberais nos anos finais da década de 1880, e também em textos oficiais do partido, como o manifesto de fundação da Tribuna Liberal, órgão de imprensa oficial da agremiação na Corte, em que os pontos fundamentais que seriam discutidos no Congresso Liberal de 1889 foram apresentados. Tribuna Liberal. 01/12/1888, p. 1.

559 Esse novo contexto será abordado com vagar no próximo capítulo.

560 Cf. Evaldo Cabral de Mello (org.), op. cit., pp. 225-227.

561 Cf. Miriam Dolhnikoff, $O$ pacto imperial.
} 
O outro lado da moeda estava no fato de que a defesa, por muitos conservadores e alguns liberais, de um novo "pacto" ou compromisso suprapartidário, nos termos daquele realizado no início da década para a aprovação da reforma eleitoral, tornava-se agora mais intrincada. As regras do jogo político haviam mudado consideravelmente, com a entrada de novos atores e demandas distintas, que rompiam com a lógica da negociação intra-elite nos espaços legítimos de representação política, passando a exigir - e exercer - um protagonismo inédito nos destinos da política imperial. É possível que o reconhecimento dessa cisão tenha ocorrido a partir da radicalização de Dantas e de uma parcela significativa do Partido Liberal, que após algumas hesitações firmou uma aliança com setores extraparlamentares que possuíam uma agenda antiescravista e democrática própria, e que não tinham pudores em reivindicar que a Coroa agisse ativamente e tomasse partido nas lutas políticas de então, desde que o fizesse em consonância com o seu partido. Mas a cisão era também expressão da realidade de um Partido Conservador em desarmonia, no qual interesses eleitorais imediatos passavam a interferir na possibilidade de formulação de um projeto político coeso para o país. O segundo ministério Saraiva, diferentemente do primeiro, foi a melancólica expressão desse estado de coisas: o último suspiro do pacto intra-elites foi uma ilusão, pois, ao assumir o poder, Cotegipe se tornou a alma de uma reação que, como toda reação, tentava o impossível, ou seja, recriar, à força, um estado de coisas que não mais existia. A partir de então, a luta política no Império se daria em novos termos. 


\section{Reforma, revolução e resistência: os partidos monárquicos nos últimos anos do Império (1885-1889)}

A historiografia tem, frequentemente, minimizado os embates políticos entre os dois grandes partidos constitucionais nos anos finais da monarquia brasileira. Conforme as interpretações de grandes estudiosos da política oitocentista, os partidos imperiais teriam surgido dos conflitos entre "facções", ${ }^{562}$ setores distintos da "classe dominante", com o predomínio de um deles no sistema, ${ }^{563}$ ou da "oligarquia" formada pelos setores da grande lavoura. ${ }^{564}$ Em outras palavras, seriam expressões mais ou menos superficiais de conflitos que, na verdade, deviam sua regulação dentro da ordem ou bem à predominância da Coroa, ${ }^{565}$ ou à preeminência de uma parcela dentre os grupos economicamente dominantes ${ }^{566}$ ou, ainda, dos interesses afinados da classe senhorial, ${ }^{567}$ servindo, no limite, de verniz ao "simulacro" representativo que caracterizaria o sistema político do Império.

O desvelamento e declínio de tal simulacro teria se iniciado, versão geralmente aceita por esses diversos autores, a partir de uma crise político-institucional engendrada pela inversão partidária de 1868 e, paralelamente, pelo surgimento de uma política emancipacionista patrocinada pelo Paço. Ligados, umbilicalmente, ora à Coroa, que garantiria sua alternância pacífica no poder sem ameaçar seus interesses mais profundos, ora ao escravismo, base de sua reprodução social, tais grupos dominantes teriam deixado gradativamente de enxergar seus interesses mais vitais representados nas bandeiras tradicionais de seus partidos, que já seriam bastante débeis e movediças. A partir de então, os partidos políticos tradicionais teriam se tornado quase que meros repositórios de discursos e programas, no limite, inócuos, com a gradual e inevitável decomposição das instituições.

562 Cf. Sérgio Buarque de Holanda, Do Império à República.

563 Cf. José Murilo de Carvalho, A construção da ordem e Teatro de sombras; Jeffrey D. Needell, The party of order.

564 Cf. Emília Viotti da Costa, Da Monarquia à República: momentos decisivos (3 ${ }^{a}$ ed.), São Paulo: Brasiliense, 1985.

565 Cf. Sérgio Buarque de Holanda, Do Império à República; Roderick J. Barman, op. cit.

566 Cf. José Murilo de Carvalho, A construção da ordem e Teatro de sombras; Christian Lynch, op. cit.; Jeffrey D. Needell, The party of order.

567 Cf. Emília Viotti da Costa, Da Monarquia à República. 
Seguindo alguns desses autores, se a inversão partidária de 1868 teria significado um "esbulho" político, com o afastamento de parte da elite do regime, as posteriores iniciativas emancipacionistas do ministério conservador chefiado por Rio Branco teriam constituído um novo esbulho, patrocinado pela Coroa, das bandeiras históricas do Partido Liberal, tornando ainda mais opaca a linha divisória entre os partidos. ${ }^{568}$ A explicitação da indistinção entre eles e de sua submissão ao predomínio do "poder pessoal" teriam possibilitado que se desvelassem tanto a superfluidade das críticas ao sistema político, quanto a inocuidade das esperanças de reformá-lo, com a consequência de se voltar tal repertório crítico contra o próprio regime. Quando o monarca, centro gravitacional das instituições e das forças políticas, se mostrou incapacitado de dirigir todos os assuntos públicos, o decorrente "vazio de poder" possibilitou que uma passeata militar derrubasse um regime que se encontrava "acéfalo". 569

Em termos não muito distantes, outros textos destacam que a inversão partidária de 1868 foi fundamental, com o afastamento de liberais e progressistas do poder, para o empobrecimento do debate político no país ao longo dos anos seguintes. Por um lado, a consequente emergência do republicanismo acabou tornando tal debate refém da questão relativa à melhor forma de governo para o país, retirando da agenda as iniciativas reformistas dos anos 1860 e ligando as alternativas substantivas de mudança à própria substituição do regime, supostamente a única solução capaz de resolver dilemas como o da federalização. ${ }^{570}$ Por outro lado, a "questão servil", entrando definitivamente no debate, teria alcançado o topo da agenda política imperial, tornando secundários todos os outros temas.

Deste modo, as duas últimas décadas do regime monárquico teriam sido marcadas por duas questões que monopolizaram as atenções: no âmbito político, a questão republicana, marcada pela dicotomia entre centralização e federação; e, no campo social, a abolição da escravidão. A república federativa passara, então, a ser encarada como a solução capaz de garantir ao "país real" a representação autêntica de seus interesses. O patrocínio da Coroa à abolição sem indenização teria, desta forma, contribuído para a percepção, por parte de

568 Cf. Sérgio Buarque de Holanda, Do Império à República, pp. 105-175.

569 Ibid., pp. 348-360. Para Roderick Barman, o monarca já vinha "abrindo mão" de seu papel-chave na sobrevivência do regime desde fins da década de 1870. A grave doença que o acometeu na segunda metade do decênio seguinte acelerou o declínio da monarquia: "A passividade de D. Pedro II privava-o de sua utilidade anterior. Com sua presença assídua, ele evitava a redistribuição de poder no âmbito do sistema político e, portanto, uma evolução pacífica desse sistema". Cf. Roderick J. Barman, op. cit., p. 487.

570 Cf. José Murilo de Carvalho, Liberalismo, radicalismo e republicanismo. 
importantes setores ligados à grande propriedade territorial, de que o poder irresponsável havia se tornado completamente insensível a seus clamores. ${ }^{571}$

Para uma corrente materialista mais clássica, representada especialmente por Emília Viotti da Costa, as instituições do Império seriam a expressão política da "estrutura colonial de produção", mantida intacta após a Independência, consistindo a tarefa dos partidos políticos a representação dos interesses oligárquicos da classe senhorial no Estado nacional em consolidação. ${ }^{572} \mathrm{O}$ desenvolvimento das forças produtivas e a consequente complexificação social ao longo do século XIX, com a superação da estrutura colonial de produção, representada pela da crise do escravismo, bem como pelo surgimento de grupos médios urbanos e de novos setores da classe dominante, inexoravelmente incompatibilizados com tal estrutura, teriam acabado por corroer os alicerces do Estado imperial. ${ }^{573}$

A crescente proeminência desses novos grupos dominantes, especialmente representados pela cafeicultura do Oeste paulista, tinha como contrapartida o declínio da classe senhorial tradicional, que possuía na escravidão a base material de sua reprodução social. Deste modo, a abolição do trabalho escravo constituiu o marco do declínio dos antigos setores oligárquicos diante da ascensão de uma avançada oligarquia ligada ao trabalho livre e tributária de valores característicos da transição ao modo de produção capitalista, então em andamento. ${ }^{574}$ Tal clivagem teria se manifestado também na crescente desigualdade regional que caracterizou o Império em suas décadas finais. À estagnação e decadência das áreas antigas da grande agricultura de exportação, o Vale do Paraíba cafeeiro e as regiões açucareiras do Norte, contrapôs-se a pujança das áreas novas, em especial o Oeste paulista. Esta desigualdade recolocou a federação no debate da época, atribuindo-lhe caráter urgente. ${ }^{575}$ Imaculada pela escravidão e avessa à centralização supostamente inerente ao Império, a república surgiria, na interpretação de Viotti da Costa, como uma readequação político-institucional do país à sua nova realidade material.

571 Cf. Id., A construção da ordem e Teatro de sombras, "A política da abolição: o rei contra os barões", pp. 291-328; Christian Lynch, op. cit., cap. 5 "Do governo parlamentar tutelado ao parlamentarismo aristocrático: o declínio do discurso monarquiano e o fim do modelo político saquarema (1868-1881)".

572 Cf. Emília Viotti da Costa, Da Monarquia à República.

573 Ibid., pp. 327-361.

574 Ibid., pp. 337-341.

575 "A identificação entre poder político e econômico e a ausência de conflitos fundamentais entre os grupos dominantes favoreceram a sobrevivência desse regime [monárquico] durante longo período, até que as contradições e conflitos gerados pelas transformações que se processam na estrutura do país, e o desequilíbrio crescente entre poder econômico e político puseram em xeque as soluções tradicionais, dando novo vigor à ideia federativa". Ibid., p. 342. 
Outra corrente historiográfica, também tributária do materialismo histórico, mas vinculada à sua vertente gramsciana, aborda a política imperial pela ótica da hegemonia de um setor da classe senhorial sobre o edifício político-institucional do Império. ${ }^{576}$ Originado da próspera cafeicultura fluminense, tal setor de classe, representado no Partido Conservador, seria portador de um projeto próprio para o Império que, graças à preeminência alcançada em meados do oitocentos, prevaleceu na consolidação do Estado imperial. Ao longo de mais de duas décadas, o apogeu do Império do Brasil teria se confundido com a hegemonia do projeto "Saquarema", que tinha na preservação da escravidão seu cerne.

Não obstante a existência de forças políticas cujas expectativas destoavam ou se opunham a tal projeto, o horizonte de ação dos homens de Estado teria se mantido confinado aos limites por ele impostos. A ação da Coroa, como "partido", no sentido gramsciano, tendo em vista também que o amadurecimento do Imperador se dera durante a construção daquela "hegemonia", garantia que tais limites não fossem ultrapassados, mesmo quando os "saquaremas" se encontravam fora do poder.

Contudo, o início da crise do escravismo acabou comprometendo a preeminência do projeto político saquarema e, consequentemente, a própria base de sustentação do Estado imperial. ${ }^{577}$ Se a reprodução social da classe senhorial que sustentava o Estado moldado pelos saquaremas estava necessariamente ligada à escravidão, seu declínio teve como consequência um realinhamento de forças políticas que acabou por expressar o início da crise final do Império. O surgimento e crescimento do abolicionismo teria sido fundamental neste processo, por corroer, simultaneamente, as instituições e os partidos políticos, inexoravelmente comprometidos com a escravidão. Não tendo mais sentido, a partir de então, as clivagens entre os partidos tradicionais e não sendo o próprio abolicionismo capaz de "tornar-se um partido e consolidar-se como alternativa moral e intelectual de longo prazo para a nação", ${ }^{578}$ com o fim da escravidão e a ascensão de outras pautas políticas à superfície, o regime, órfão de alicerces seguros na sociedade em transformação, não teria resistido à avalanche.

Se, portanto, são colocadas, lado a lado, as interpretações citadas, tem-se a impressão

576 Ver, especialmente, Ilmar Rohloff de Mattos, O tempo Saquarema. São Paulo: Hucitec, 1987.

577 Ricardo Salles, “As águas do Niágara. 1871: crise da escravidão e o ocaso saquarema”, in Keila Grinberg

e Ricardo Salles (org.), O Brasil Imperial, vol. III: 1870-1889, Rio de Janeiro: Civilização Brasileira, 2009, pp. 72-73.

578 Ibid., pp. 75-76. 
de que os partidos imperiais chegaram à década final da monarquia em condições de fragilidade que iam além de sua tradicional debilidade frente a um sistema representativo descrito sempre como trôpego e constantemente falseado. Tendo em vista a natureza supostamente centralizada do Estado imperial, prenhe da intervenção ativa do Poder Moderador, os projetos políticos que pugnavam pela autenticidade do sistema representativo, pela descentralização política e pela transição ao trabalho livre, entravam necessariamente, mais cedo ou mais tarde, tal como se depreende das interpretações citadas, em rota de colisão com o regime, especialmente após a grave crise iniciada no triênio 1868-1871. Destarte, temas relacionados à reforma do Estado são geralmente interpretados como apanágio dos Partidos Republicanos, que teriam sido bem-sucedidos em aguardar que o Estado monárquico levasse a cabo sua própria decomposição, tendo na desastrada "política da abolição", perseguida em suas décadas finais, um elemento sobressaliente desse "plano inclinado". 579

Contudo, se nos debruçamos sobre a documentação, atentando aos projetos presentes nos discursos e programas dos partidos políticos e dos homens de Estado a eles pertencentes, é possível entrever que as disputas e embates estavam longe de superficiais e retóricos. Eram, pelo contrário, tributários de visões e expectativas distintas para o país, que, se por muito tempo foram negociáveis, parecem ter ganhado um tom drástico no decorrer das lutas políticas da década de 1880, com pretensões que se mostravam diametralmente opostas. Tais pretensões, por mais irreconciliáveis que se demonstrassem, revelavam antes uma disputa pelo futuro do Império do Brasil do que por suas ruínas. Contribuir com a compreensão do sentido das lutas políticas entre os dois grandes partidos constitucionais nos anos que precederam o golpe de Estado de 1889 é, nesses termos, o que se pretende no capítulo final da presente dissertação.

\section{1 - Federação e democracia}

Em 25 de agosto de 1885, um dia após a apresentação do ministério Cotegipe à Câmara dos Deputados, os liberais, novamente reunidos, votaram uma moção de desconfiança contra o gabinete conservador, que resultaria na dissolução da $19^{\mathrm{a}}$ legislatura 
e na convocação de novas eleições para o início do ano seguinte. ${ }^{580}$ Concordando, não sem divisões, em ceder ao governo ascendente as condições de vida, por meio da votação das leis orçamentárias, setores do Partido Liberal, como se procurou demonstrar no capítulo anterior, aliavam um espírito de derrota e previsões funestas para o futuro do partido a um ímpeto de renovação expresso no avançado reformismo. Foi nesse contexto que Joaquim Nabuco apresentou, pela primeira vez, à Câmara dos Deputados, seu projeto de monarquia federativa. $^{581}$

"[R]evive hoje nesta Câmara", declarou Nabuco, "o projeto que, em outubro de 1831, o Partido Liberal mandou ao Senado, e que expressa a qualidade do liberalismo forte, másculo e patriótico da geração que fez o Sete de Abril". ${ }^{582}$ Tendo sido aquele projeto a origem do Ato Adicional, destacou o liberal abolicionista, era necessário que fosse resgatado, num momento em que o país lidava com dilemas graves, que remetiam àqueles enfrentados pelos responsáveis pela Abdicação do primeiro imperador. O Partido Liberal tinha, como obrigação, avivar e garantir a realização das reformas de que o país tão urgentemente necessitava:

[...] é preciso que em todas as outras causas da atrofia e da decadência nacional, o partido da reforma chegue a tempo; e, portanto, neste momento, em que ainda é possível salvar o futuro das províncias, o Partido Liberal está no seu posto, querendo levar ao fim simultaneamente as duas grandes reformas, que são uma o complemento da outra, que se associam entre si, que se dão força mutuamente, e que representam juntas esse ideal nacional de uma pátria reconstituída. (muito bem!) ${ }^{583}$

A abolição e a federação eram, seguindo tal discurso, dois lados da mesma moeda, representavam a liberdade individual e a autonomia das províncias. Seu caráter liberal e democrático estava na dupla libertação que, realizadas conjuntamente, possibilitariam: a emancipação dos escravos em relação a seus senhores e das províncias em relação ao centro de poder no Rio de Janeiro. Da mesma forma que os cativos viviam na mais abjeta condição de sujeição e dependência com relação a seus senhores, as províncias viviam sem acesso à independência que as restituiria sua "integridade", reconstituindo, pela sua união ao Brasil como estados livres, a pátria em novos termos.

580 ACD. 25/08/1885, pp. 53-54.

581 O projeto foi apresentado na sessão de 14/09/1885. Apud Evaldo Cabral de Mello, Essencial Joaquim Nabuco, pp. 195-229.

582 Ibid., pp. 195-196.

583 Ibid., p. 199. 
“É absolutamente impossível”, asseverou Nabuco, "fazer de um governo, com raízes nesta corte, um governo verdadeiramente provincial de espírito e de coração". ${ }^{584}$ Para que a obra do Ato Adicional fosse plenamente resgatada e completada, era necessário ir além do que dispusera a própria emenda constitucional, transformando os presidentes de província, até então "homens sem independência", 585 em agentes da administração eleitos localmente e que respondessem apenas a seus eleitores, nas respectivas províncias. Cabia aos autênticos liberais, contudo, perceber que, a fim de colocar verdadeiramente em pauta as "reformas democráticas", era necessário que o partido se democratizasse, em primeiro lugar.

Sujeito à "autoridade de chefes inimigos entre si", que no Senado muitas vezes se encontravam em posições conflitantes, os liberais tinham dificuldade em vencer os limites impostos pelo Imperador e pelo ramo vitalício do Poder Legislativo às amplas reformas que estavam no seu programa. Diante de tal panorama, era necessário uma reorganização do Partido Liberal, não mais em torno de seus chefes, mas em torno de "ideias que sejam grandes aspirações nacionais". A única forma de levar a cabo tais aspirações estava na transformação do partido em uma vasta "União Democrática", como Nabuco já propusera meses antes. 586 "Mas para isso", declarou o deputado pernambucano,

é preciso que o Partido Liberal coloque a sua força, não em alguns indivíduos que se sentam no vértice da pirâmide social, mas nas extensas camadas populares sobre que ela se levanta (apoiado)

Convença-se o Partido Liberal disso, hasteie a grande bandeira da abolição, da federação e da paz: a abolição, que é o trabalho e a terra; a federação que é a independência e o crescimento; a paz, que é o engrandecimento exterior e a expansão legítima de todos os estímulos da atividade nacional; e esse partido há de mostrar, qualquer que seja o seu número, que é a maior força deste país, porque o coração do país está ainda são, é ainda profundamente liberal e democrático. ${ }^{587}$

Com o fracasso, ao menos temporário, da "solução liberal" à questão servil, a bandeira da federação deveria ser levantada, num momento de "eclipse" não só do abolicionismo, mas do Partido Liberal, que passara à oposição após tentar compor com seus adversários, cedendo de forma inaceitável às suas pressões. Dispunha o projeto de monarquia federativa de Nabuco:

584 Ibid., pp. 208-209.

585 Ibid., p. 209.

586 ACD. 03/07/1885, p. 155.

587 Apud Evaldo Cabral de Mello (org.), Essencial Joaquim Nabuco, p. 227. 
A Assembleia Geral Legislativa resolve:

Artigo único. - Os eleitores de deputados à próxima legislatura darão aos seus representantes poderes especiais para reformarem os artigos da Constituição que se opuserem às proposições seguintes:

O governo do Brasil é uma monarquia federativa.

Em tudo que não disser respeito à defesa externa e interna do Império, à sua representação exterior, à arrecadação dos impostos gerais e às instituições necessárias para garantir e desenvolver a unidade nacional e proteger efetivamente os direitos constitucionais de cidadãos brasileiros, os governos provinciais serão completamente independentes do poder central. ${ }^{588}$

Além do próprio Joaquim Nabuco, outros 37 deputados liberais, representando dezesseis províncias e o Município Neutro, assinaram o projeto. Destes, a imensa maioria havia apoiado o ministério Dantas na votação de confiança do início de maio daquele ano, em que, por dois votos, o senador baiano fora derrotado. ${ }^{589}$ Agora, frente à ascensão dos adversários, em um contexto no qual apareciam como pouco animadores os resultados das iniciativas reformistas dos sete anos de situação liberal, muitas delas malsucedidas, tais deputados precisavam lidar com a dura realidade de se encontrarem na oposição, alguns deles pela primeira vez desde que haviam chegado ao Parlamento, como era o caso do próprio Joaquim Nabuco. ${ }^{590}$

As decepções com as reformas promovidas pelo partido tinham duas origens. A Lei Saraiva, frequentemente criticada como restritiva, havia sido, destacavam esses políticos, fruto de concessões aos conservadores que se provaram mais profícuas aos adversários do que ao próprio Partido Liberal. Nesse sentido, José Mariano não deixava Saraiva esquecer que, ao manter nas mãos de magistrados dependentes do centro a palavra final sobre o alistamento eleitoral, obra das emendas conservadoras, a lei de 1881 havia permanecido "incompleta". ${ }^{591}$ Da mesma forma, argumentavam diversos liberais, as concessões quanto à prova de renda, com a diminuição do eleitorado previsto, haviam se mostrado favoráveis aos adversários. A manutenção da vitaliciedade do Senado, por sua vez, não permitira que o protagonismo absoluto na condução da política nacional passasse à Câmara dos

588 Ibid., p. 228.

589 Os únicos dois dissidentes que assinaram o projeto foram os mineiros João Penido e Sebastião Mascarenhas. Com as divisões posteriores do Partido Liberal quanto à federação, que serão abordadas adiante, os representantes liberais de Minas Gerais, que geralmente defendiam a bandeira federativa, também se mostraram divididos, com aqueles mais ligados à Zona da Mata cafeicultora aderindo ao republicanismo. Ibid., p. 238; ACD. Sessão de 1885, tomo III, pp. 5-6.

590 Nessa lista, encontravam-se também, entre outros, José Mariano, Sátiro Dias, Afonso Celso Jr. e Aristides Spinola. Cf. Barão de Javari, op. cit.

591 ACD. 07/08/1885, p. 388. 
Deputados, uma das motivações da reforma. Tendo tudo isso em vista, parecia um futuro pouco auspicioso aquele que se reservava ao partido quando o poder coubesse a um governo conservador.

Além disso, as iniciativas dos gabinetes da primeira metade da década - e que poderiam desmantelar as disposições conservadoras da lei eleitoral, como a reforma do alistamento mediante expansão do sufrágio ou a neutralização da intervenção do governo, com a independência do Poder Judiciário e a reforma dos municípios - foram abortadas devido a alianças entre conservadores e dissidentes liberais em votações de confiança. ${ }^{592}$

De fato, com a adoção da eleição direta por distritos uninominais, a instabilidade ministerial crescera grandemente. A neutralidade do governo e a ampla competição eleitoral no primeiro pleito realizado sob o novo sistema haviam levado à câmara temporária uma significativa bancada conservadora. Uma minoria ampla significava que dissidências pontuais no seio do partido do governo poderiam ser fatais, o que realmente ocorreu e possibilitou que os quatro governos que sucederam Saraiva fossem derrubados sem que, sequer, pudessem começar a realizar seus programas. Deste modo, os efeitos da Lei Saraiva, até então, haviam sido, de certa forma, paradoxais. A lei liberal aumentara a competição eleitoral e garantira maior representação aos interesses das localidades no Parlamento, com o preço de ver crescer a indisciplina na bancada do partido e dificuldades em relação à manutenção da governabilidade.

Mais do que isso, consideravam importantes setores do Partido Liberal, a manutenção de atributos centralistas na definição do eleitorado e na condução dos pleitos, deixara sua obra descentralizadora pela metade. Apesar da aproximação entre candidatos e eleitores nos distritos, os chefes provinciais e nacionais do partido, estes últimos ocupando cargos senatoriais que se mantinham vitalícios, ainda retinham grande poder em suas mãos, especialmente no que dizia respeito à distribuição dos candidatos pelos distritos e à própria definição de quem seriam esses candidatos, bem como na repartição dos cargos do funcionalismo público. ${ }^{593}$ Nacionalmente, a Câmara dos Deputados aprimorava a prática

592 Cf. Sérgio Eduardo Ferraz, op. cit., pp. 171-189. Ver também a introdução do capítulo 2 da presente dissertação.

593 Isto ficou bastante evidente no esforço feito pelo gabinete Dantas para pressionar Luís Filipe de Sousa Leão, chefe do Partido Liberal pernambucano, a garantir candidatura de Nabuco em um distrito viável, com a contrapartida de se entregar a seus aliados postos-chave na magistratura da província. Documentos do próprio punho do Cons. Luís Filipe de Sousa Leão relatando conferências políticas. AIHGB. Col. Sousa Leão, DL 456.136. Na campanha que precedeu as eleições seguintes, entre fins de 1885 e início de 1886, já sob administração conservadora, Antônio de Siqueira, candidato a deputado geral no mesmo distrito que o filho de João Alfredo, lamentava as dificuldades que a intervenção de José Fernandes da 
questionável do "terceiro escrutínio", politizando o reconhecimento de deputados e, assim, concentrando um grande poder em suas mãos. Se não fora possível solucionar tais impasses por regulamentação da lei eleitoral ou legislação que a tangenciasse, recursos mais drásticos, antes colocados em segundo plano, ganhavam caráter de urgência.

As eleições de 1886 realmente confirmaram todos os temores dos liberais. Além da intervenção do gabinete Cotegipe no favorecimento aos candidatos conservadores, as divisões internas no Partido Liberal, profundamente agravadas pelas disputas ocorridas durante os governos Dantas e Saraiva, tornaram a derrota ainda mais acachapante. ${ }^{594}$

Segundo o senador Pedro Leão Veloso, mais do que a interferência do "elemento oficial", fora a "desorganização" inoculada pelos "neo-liberais" que comprometera a posição do partido no pleito, impedindo-o não de conquistar a vitória, que se mostrava cenário improvável, mas de eleger bancada ampla. Em São Paulo, vaticinava o senador baiano, "os liberais teriam eleito quatro deputados se o [...] José Bonifácio não tomasse a si a reconstrução do partido por largas base [sic] do verdadeiro liberalismo auxiliando os adversários". ${ }^{595}$ Mesmo frente ao desastre eleitoral e à sua dificuldade em angariar fundos, assinalava Leão Veloso, Joaquim Nabuco "não perde esperança de ser o chefe do neoliberalismo, mas vai caindo na realidade". ${ }^{596}$ Desgostoso com a "grande política", declarava-se o senador baiano, restava esperar o que fariam os "grandes ministros" conservadores para "remediar os erros dos liberais", e que conquistas alcançaria "o neoliberalismo, para organizar o partido, excluindo-nos do grêmio, como quer o Rui [Barbosa]".597

Em Pernambuco, a situação não parecia tão diferente. Antônio de Siqueira, cuja deserção havia provocado a derrota do ministério Dantas, ${ }^{598}$ indicava temer, na mesma medida, a intervenção dos conservadores no pleito e o "conciliábulo" que os "dantistas ou

Costa Pereira Jr., então presidente de Pernambuco, poderiam lhe causar, devido às ameaças que já se preparava "para obter abstenção, senão favor da administração provincial". Antônio Manuel de Siqueira Cavalcanti a Francisco de Carvalho Soares Brandão, 12/12/1885. AIHGB. Col. Soares Brandão, DL 611.42 .

594 Elegeram-se, no pleito, 103 conservadores contra apenas 22 liberais. A vantagem conservadora sofreria gradual diminuição nos anos seguintes, pois os liberais venceriam a imensa maioria dos pleitos extemporâneos, entre os anos de 1886 e 1888, derrotando, inclusive, ministros de Cotegipe. Cf. Barão de Javari, op. cit., pp.398-400.

595 A divisão entre duas alas do Partido Liberal paulista, uma chefiada por Moreira de Barros e outra por José Bonifácio, parece ter se tornado verdadeiramente fratricida a partir do pleito de 1885, em que o senador chegou a se aliar até mesmo com republicanos para impedir a vitória dos candidatos "escravocratas" ligados ao correligionário. Cf. Guo-Ping Mao, op. cit., pp. 209-211.

596 Leão Veloso a Saraiva, 07/03/1886. AIHGB. Col. Saraiva, DL 273.37. Grifos no original. 597 Leão Veloso a Saraiva, 14/03/1886. AIHGB. Col. Saraiva, DL 273.37, doc. 6. Grifos no original. 598 ACD. 04/05/1885, pp. 3-12. 
anarquistas" haviam realizado, quando, além de "decretar" sua derrota, bradaram contra a vitaliciedade do Senado e a preponderância do chefe liberal da região, o senador Francisco de Carvalho Soares Brandão. ${ }^{599}$ Na província vizinha, a Bahia, por sua vez, o fracasso nas eleições, declarou César Zama, demonstrava que o Partido Liberal não podia se sustentar somente pelo barulho das ruas ou pelos artigos de escritores radicais, uma vez que a divisão entre "Saraivistas e Dantistas" parecia se prolongar. ${ }^{600}$ O próprio Saraiva lamentara, durante o pleito, os efeitos perversos que a radicalidade, dos que chamava, ironicamente, de "verdadeiros liberais", causavam nas perspectivas eleitorais do partido. Para o senador baiano, a radicalização dos conflitos políticos prejudicava o legado da lei eleitoral de sua responsabilidade: "Parece que o sistema parlamentar em todo o mundo está em prova porque as frações moderadas dos partidos estão ameaçadas em toda a parte de serem dominadas pelos viscerais e intransigentes". ${ }^{601}$

Desta forma, no decorrer do ano de 1886, enquanto, no Parlamento, Dantas e seus aliados iniciavam uma nova ofensiva contra a escravidão, apresentando projeto alternativo que cancelava a lei aprovada menos de um ano antes, ${ }^{602}$ nas províncias, diversos "neoliberais", muitos dos quais derrotados no pleito do início do ano, ${ }^{603}$ se mobilizavam no sentido de reformar, ou até mesmo refundar, o Partido Liberal. Era o caso emblemático de José Mariano Carneiro da Cunha, cuja província, Pernambuco, passara a possuir bancada quase unanimemente conservadora na $20^{\mathrm{a}}$ legislatura. ${ }^{604}$

Sem o conhecimento dos chefes tradicionais de seu partido, José Mariano havia

599 Antônio de Siqueira a Soares Brandão, 12/12/1885. AIHGB. Col. Soares Brandão, DL 611.42.

600 César Zama a Saraiva, 15/07/1886. AIHGB. Col. Saraiva, DL 274.49, doc. 7.

601 Saraiva a Soares Brandão, 02/01/1886. AIHGB. Col. Soares Brandão, DL 611.17, doc. 7.

$602 \mathrm{O}$ projeto de abolição, apresentado por Dantas em junho de 1886, previa que em cinco anos seriam

"considerados livres todos os escravos existentes no Império" e que no mesmo prazo "ficariam absolutamente extintas as obrigações de serviço impostas aos ingênuos pela lei de 28 de setembro de 1871". AS. 01/06/1886, pp. 3-9. Seis dias depois, o projeto foi rejeitado por uma comissão especial formada majoritariamente por senadores conservadores, além de Martinho Campos. AS. 07/06/1886, pp. 76-77.

603 Não obstante, dos liberais eleitos em 1886, a maioria havia apoiado o ministério Dantas no ano anterior. Provinham eles de São Paulo, com Martim Francisco Ribeiro de Andrada; do Paraná, com Manuel Alves de Araújo; de Santa Catarina, com Duarte Paranhos Schutel e Manuel da Silva Mafra; do Rio Grande do Sul, com Antônio Eleutério de Camargo, Joaquim Pedro Salgado, Egídio Barbosa de Oliveira Itaqui, Francisco Antunes Maciel, José Francisco Diana e Joaquim Pedro Soares; de Minas Gerais, com Cândido de Oliveira, Carlos Vaz de Melo, Carlos Afonso de Assis Figueiredo, Eduardo Augusto Montandon e Afonso Celso Jr.; de Goiás, com André Fleury e José Leopoldo de Bulhões Jardim; e do Mato Grosso, com Augusto Fleury. Cf. Barão de Javari, pp. 383-387.

604 A exceção era o deputado liberal Pedro da Cunha Beltrão. Ibid., p. 384. José Mariano, como outros diversos deputados liberais eleitos, haviam sido "degolados" pelo "terceiro escrutínio" da verificação de poderes na Câmara. No Senado, os liberais denunciaram seguidamente a condescendência de Cotegipe com as ações de seus correligionários no ramo temporário do Poder Legislativo. Saraiva afirmou que tais procedimentos ilegítimos comprometiam o sistema da lei eleitoral de 1881. AS. 29/05/1886, pp. 184-185. 
organizado um grande meeting liberal com vistas a "congraçar" o partido em Pernambuco e estabelecer pontos para a formulação de um programa. Após a realização da conferência, o liberal abolicionista enviou a Luís Filipe de Sousa Leão seus resultados, recomendando que os chefes do partido no Senado se inteirassem do conteúdo que se ensaiava para o programa. ${ }^{605}$ A reorganização do partido, se iniciando com a "união manifestada por todos os nossos amigos", deveria começar com a eleição de um diretório provincial. A reunião tivera a meta de levantar a "ideia da nomeação de uma comissão incumbida de convocar o partido da província para tal fim”. Destarte, “[t]ratando-se da reorganização do partido", parecera a José Mariano "necessário formular um programa que traduzisse as nossas aspirações, em favor das quais pudéssemos fazer a propaganda na imprensa". Já que na Corte, "as desinteligências entre os chefes não permitiram um acordo a tal respeito", o liberal abolicionista e seus colegas tomavam para si tal tarefa:

Nestas condições, entendi que não podíamos guardar silêncio sobre a questão servil que hoje se impõe forçadamente a todos os partidos, e por isso, sem pretender indicar ao partido [liberal] a $\mathrm{m}$ [inha] opinião radical na questão, contentei-me em propor que fosse aceita a abolição conciliadora contida no projeto apresentado ao Senado por alguns dos chefes liberais e que em breve será aceita por todo o nosso partido. ${ }^{606}$

Entendi também que não podíamos pôr de lado a questão da reorganização das províncias, nem a grave questão da organização do trabalho livre, conciliando as necessidades deste com os interesses do solo e do capital, chamados a desenvolver o mesmo trabalho livre, sem que com isto vamos cair na teoria socialista.

$\mathrm{O}$ alargamento do sufrágio, a instrução técnica e profissional e as garantias aos funcionários públicos são também ideias que me pareceu conveniente incluir em nosso programa de combate.

Todas essas ideias representam legítimas aspirações do partido. ${ }^{607}$

Visivelmente recalcitrante, Luís Filipe não rejeitou explicitamente as pretensões de seu correligionário, mas listou os mais variados empecilhos que dificultariam seu sucesso, ao menos em curto prazo. ${ }^{608}$ Não contestando, “em tese, a vantagem de um diretório que sirva de centro e guia ao nosso partido, unificando-lhe a ação e indicando-lhe a senda que deve trilhar", o senador, contudo, apontava para as dificuldades presentes em tal proposta, visto ser "questão de importância transcendente", que lhe pareciam não dever "ficar

605 José Mariano Carneiro da Cunha a Luís Filipe de Sousa Leão, 04/08/1886. AIHGB. Col. Sousa Leão, DL 457.52.

606 José Mariano se referia ao projeto Dantas, acima citado, assinado também por Silveira da Mota, Franco de Sá, Francisco Otaviano, Henrique d'Ávila, Joaquim Raimundo de Lamare, Liberato de Castro Carreira e pelo visconde de Pelotas. AS. 01/06/1886, p. 8.

607 José Mariano a Luís Filipe de Sousa Leão, 04/08/1886. AIHGB. Col. Sousa Leão, DL 457.52.

608 Luís Filipe de Sousa Leão a José Mariano, 17/08/1886. AIHGB. Col. Sousa Leão, DL. 456.147. 
sujeitas a solução de conveniência duvidosa ou problemática". ${ }^{609}$ No mesmo sentido, o senador não escondeu suas reservas ao programa ensaiado pelo meeting convocado por José Mariano, afirmando ter "dúvidas em admiti-lo integralmente", pois seu "espírito ainda não se adiantou tanto, que possa aceitar as soluções extremas" que eram dadas a algumas das questões estabelecidas:

A da emancipação por exemplo. Tendo feito parte do gabinete 6 de Maio [Saraiva], que formulou e fez passar a lei de 28 de setembro de 1885, não posso com tão pequeno intervalo, reconhecer a necessidade de sua derrogação. Não assinei o projeto 'Dantas' e atualmente ainda não estou convencido de suas vantagens. ${ }^{610} \mathrm{E}$ possível que isto venha a suceder mais tarde, ou mesmo que maiores exigências me pareçam razoáveis, mas presentemente mantenho-me em meu terreno.

Os outros pontos, exceção feita do [sic] que se refere às relações do solo e trabalho, que pelo modo indefinido e vago como está contido no programa, pode obrigar a um desenvolvimento que roce pelas raias do socialismo, do qual me conservo muito distanciado, merecem em geral minha adesão, mais ou menos acentuada, atentos os detalhes sobre que oportunamente se houver de resolver. ${ }^{611}$

A principal objeção, no entanto, era com relação à organização provincial de um programa para o partido, "porquanto constituindo os liberais de todo o império uma só comunhão, comum deve ser a lei que nos reja”. Deste modo, o senador declarava entender que

o programa do partido liberal deve ser feito aqui [Rio de Janeiro], como aconteceu em 1868 e é de razão, por ser este o lugar em que se reúnem em mais cópia as sumidades políticas do país. E todas as normas que deste centro não partirem, hão de morrer de inanição, porque falta-lhes o cunho do consenso geral. ${ }^{612}$

Mesmo "incompleta", a lei eleitoral de 1881 havia a aberto possibilidade de que "notabilidades" locais e provinciais dos partidos questionassem a predominância dos chefes políticos, cuja maioria alocava-se na câmara vitalícia. Por sua vez, as disputas encetadas no decorrer da primeira metade da década de 1880, com o ganho de influência da ala mais marcadamente reformista do Partido Liberal e sua aliança com forças

609 Ibid.

610 Como veremos mais adiante no presente capítulo, a regulamentação da chamada Lei dos Sexagenários, de responsabilidade de Antônio Prado, ministro da Agricultura sob Cotegipe, foi amplamente criticada, até mesmo entre setores do Partido Conservador, por destruir suas características emancipacionistas, pretendendo prolongar ao máximo possível a existência do trabalho escravo, até o fim do século XIX. Não era de se estranhar, portanto, que setores do Partido Liberal já quisessem suprimi-la pouco depois de sua promulgação.

611 Luís Filipe de Sousa Leão a José Mariano, 17/08/1886. AIHGB. Col. Sousa Leão, DL. 456.147. 612 Ibid. 
extraparlamentares crescentes (em número, organização e radicalidade), proporcionavam a esses "neo-liberais" uma base de apoio com a qual provavelmente não poderiam contar em outros tempos, especialmente nos centros urbanos. Destarte, a iniciativa de José Mariano, que Luís Filipe de Sousa Leão parecia medir palavras para desqualificar, em promover a organização do Partido Liberal de Pernambuco em bases provinciais, com um diretório eleito e programa votado por seus membros, pode ser compreendida, dentro de tal contexto, como um desafio claro à preeminência do "poder pessoal" dos chefes de partido que a reforma de 1881 não havia conseguido neutralizar. Intrinsecamente vinculada a tal iniciativa estava, portanto, a defesa que José Mariano fazia não só da extensão do sufrágio, como da ampliação das franquias provinciais e da temporariedade do Senado, com parlamentares eleitos diretamente, sem intervenção do centro. Partidos provincialmente e "democraticamente" organizados só poderiam ser bem-sucedidos se fossem garantidos, a grandes camadas da população, direitos de participação política, bem como às províncias vastas prerrogativas na gestão de seus próprios negócios. O tripé “Abolição, Federação e Paz", defendido por Joaquim Nabuco, ganhava cores intensas tendo em vista tais expectativas.

No mesmo sentido, a defesa da "restauração do regime democrático" das reformas da década de 1830 ganhava também intensidade nos discursos de diversos deputados liberais no decorrer daqueles anos. Não apenas o Ato Adicional havia transformado os Conselhos de Províncias em Assembleias Provinciais, dividindo competências entre o centro e as províncias, como havia suprimido o Conselho de Estado. Além disso, entre as disposições originais da emenda constitucional, estavam o fim da vitaliciedade do Senado e a definição do regime brasileiro como uma "monarquia federativa", pontos que não puderam se tornar realidade naquele momento, ${ }^{613}$ mas que, na década de 1880 , ganharam uma urgência sem precedentes. ${ }^{614}$ Ademais, estavam na mira do reformismo liberal também as leis de 23 de novembro e de 3 de dezembro de 1841 que haviam, respectivamente, criado um novo Conselho de Estado e reformado o Código de Processo Criminal de $1832 .{ }^{615}$ Deste modo, o

6130 termo "monarquia federativa" foi retirado do texto final da emenda. A temporariedade do Senado, por sua vez, foi rejeitada pela câmara alta. Para o Ato Adicional e sua revisão, ver: Miriam Dolhnikoff, $O$ pacto imperial, cap. 2 "O arranjo institucional".

614 Alguns deles já haviam sido recuperados pela rearticulação do partido, em fins da década de 1860. Cf. Américo Brasiliense de Almeida e Melo, op. cit., pp. 21-40.

615 Cf. Miriam Dolhnikoff, O pacto imperial, cap. 2 "O arranjo institucional"; Monica Duarte Dantas, "O código do processo criminal e a reforma de 1841 ". 
projeto federalista e de base "cidadã",616 retornava, num momento crítico, como fora aquele da década de 1830, com força total nas fileiras do partido. Desejava-se, então, muito mais do que simplesmente alargar as prerrogativas das províncias, como explicou o deputado mineiro Cândido de Oliveira:

Ela não se confunde com a desconcentração, que, como nas hipóteses figuradas, é a delegação das funções de um poder a agentes inferiores desse mesmo poder. Descentralização quer dizer divisão dos poderes, alargamento da esfera dos poderes, quer dizer independência e autonomia das províncias; é o alargamento de suas regalias e o respeito às que existem. ${ }^{617}$

Esse projeto “descentralizador" ganhou, nos anos 1880, um caráter vigorosamente democrático, especialmente entre os setores mais avançados do partido, então fortalecidos. Ele tinha na ideia de autogoverno seu alicerce mais fundamental. Para além de uma resposta às desigualdades crescentes entre as províncias, aprofundadas pela crise da escravidão - e que faziam com que as elites das províncias que mais rapidamente se desenvolviam economicamente, especialmente no caso das que se sentiam subrepresentadas no sistema político, aderissem a projetos federativos ou, até mesmo, separatistas,$-{ }^{618}$ o projeto liberal era também consideravelmente inclusivo. ${ }^{619} \mathrm{O}$ propalado florescimento da vida local estava diretamente ligado à democratização política e, até certo ponto, social do país, com a expansão do sufrágio, a reorganização dos partidos em bases "populares" e a própria facilitação do acesso à terra. Nesse sentido, era também um projeto de superação rápida da escravidão e das relações sociais por ela pautadas, em que estavam

616 Segundo Monica Dantas, o aparato judiciário criado pela reforma liberal de 1832 configurava uma “justiça cidadã”. Ibid., p. 6.

617 ACD. 21/06/1886, p. 410.

618 Era o caso emblemático de São Paulo, em que chegou a se desenvolver um movimento separatista, capitaneado por Alberto Sales, irmão de Campos Sales. Cf. Cássia Chrispiniano Aducci, A "Pátria Paulista": o separatismo como resposta à crise final do Império Brasileiro, São Paulo: Arquivo do Estado/Imprensa Oficial, 2000. Para a situação econômica do país na década de 1880, a crescente desigualdade econômica regional e as consequências do processo de abolição nas diferentes províncias, ver: Liberato de Castro Carreira, História financeira e orçamentária do Império do Brasil; Brasília: Senado Federal/ Rio de Janeiro: Fundação Casa de Rui Barbosa, 1980; Evaldo Cabral de Mello, O Norte agrário e o Império: 1871-1889 (2 $2^{\mathrm{a}}$ ed.), Rio de Janeiro: Topbooks, 1999; B. J. Barickman, "Até a véspera: o trabalho escravo e a produção de açúcar no recôncavo baiano (1850-1888)". Afro-Ásia, vol. 21-22, 1998-1999, pp. 177-238; Francisco Marques de Góes Calmon, Vida econômico-financeira da Bahia: elementos para a história de 1808-1899, Salvador: Fundação de Pesquisas, 1979; Peter L. Eisenberg, Modernização sem mudança: a indústria açucareira em Pernambuco, 1840-1910, Rio de Janeiro: Paz e Terra/ Campinas: Unicamp, 1977; John Schulz, A crise financeira da abolição, São Paulo: Edusp, 1997.

619 Para uma discussão sobre o caráter conservador do federalismo republicano paulista, ver: Luaê Carregari Carneiro Ribeiro, Uma América em São Paulo: a Maçonaria e o Partido Republicano Paulista. Dissertação de Mestrado em História Social, São Paulo: FFLCH/USP, 2011, pp. 151-155 
em tela contrapartidas ao predomínio da grande propriedade territorial, bem como a efetivação de direitos políticos a amplas parcelas da população. Nestes termos, deve-se levar em conta a segunda origem das profundas decepções com as reformas promovidas durante os sete anos de situação liberal.

Se o arcabouço da lei da eleição direta precisava ser revisto, levando-se em conta a necessidade de se adotar medidas que neutralizassem as concessões feitas aos adversários, principalmente no que dizia respeito à extensão do sufrágio, a legislação concernente à escravidão apresentava desafios ainda maiores. Mais do que concessões, a Lei dos Sexagenários foi enxergada como uma "capitulação" do Partido Liberal aos adversários, permitindo não só que emendassem livremente o projeto apresentado (sob égide do gabinete Saraiva, em 1885), por si só já demasiadamente moderado, como conduzissem o processo de implementação da lei, regulando-a desembaraçadamente.

O Decreto de regulamentação da chamada Lei dos Sexagenários, promulgado em meados de novembro de 1885, por Antônio Prado, ministro da Agricultura, teve claramente o objetivo de postergar ao máximo a emancipação dos escravos, estabelecendo como prazo para a libertação total do país o último ano do século XIX. Para isso, se definiu, em primeiro lugar, que o início da dedução anual do valor dos escravos só se daria após terminada a realização da matrícula, não contando da data da promulgação da lei, o que por si só adiou em um ano e meio o prazo para a extinção do cativeiro. Permitiu, também, a regularização de toda a propriedade servil de origem duvidosa, ao garantir que não se perguntaria a origem do escravo, mas sua filiação, podendo esta ser declarada como “desconhecida". Mais ainda, a proibição do tráfico interprovincial foi relativizada, ao menos para o comércio entre a capital do Império e a província do Rio de Janeiro, onde o braço escravo era abundantemente utilizado, alegando-se, num esforço interpretativo que ia de encontro ao disposto na lei, não constituir o Município Neutro circunscrição própria. $^{620}$

Se, por um lado, como veremos adiante, isso acabou por minar irreversivelmente a unidade do Partido Conservador, contribuiu também para criar condições favoráveis ao fortalecimento do antiescravismo no Partido Liberal, mesmo entre seus elementos mais

620 As informações são de Angela Alonso, Flores, Votos e Balas, p. 273. É bastante provável que tais disposições, significativamente mais severas do que aquilo que o próprio Antônio Prado afirmava desejar, tenham sido concessões à ala do Partido Conservador comandada por Paulino de Souza, bastante contrariada pela nova lei emancipacionista. Na seção seguinte do presente capítulo se tratará mais pausadamente de tal questão. 
recalcitrantes. A explosão da violência no meio rural, com a mobilização de um abolicionismo rearticulado para a ação direta, frente à brutal repressão do ministério Cotegipe ao movimento, encetou um clímax de conflagração social generalizada. ${ }^{621}$ Parcamente representados na Câmara, mas resilientes no Senado, os liberais exerceram uma pressão sem precedentes contra a política do gabinete, tentando combater não só o "Regulamento Negro", mas a política ministerial como um todo. A primeira derrota de Cotegipe ficou marcada por uma rendição do governo em fins de 1886, representada pela supressão do uso de açoites pelo Estado nas punições a escravos, o que parece ter sido uma tentativa de ceder em um ponto para preservar o arcabouço geral da política concernente à escravidão. ${ }^{622}$

A situação se inflamou de forma irreversível em 1887. Ficando rapidamente evidente que o governo não dispunha mais de meios para conter a avalanche, o Partido Liberal apresentou, na figura de Afonso Celso Jr., um projeto de abolição imediata da escravidão, que parecia congregar todas as alas do partido:

A Assembleia Geral resolve:

Art. $1^{\circ}$. Serão declarados livres desde a data da promulgação desta lei todos os escravos matriculados no Império.

$\S 1^{\circ}$ Os libertos por virtude desta disposição ficam obrigados à prestação intransferível de serviços aos seus ex-senhores, pelo prazo de dois anos.

Desta obrigação excetuam-se:

$\S 2^{\circ}$ Os que remirem-se dela por pagamento em dinheiro, não podendo, neste caso, os serviços pela totalidade do prazo ser estimados em quantia maior de $500 \$$, e continuando em vigor, para o efeito desta estimação, o processo de avaliação estipulado no regulamento n. 5135 de 13 de Novembro de 1872.

$\S 3^{\circ}$ Os maiores de 50 anos e os que, no decurso do prazo indicado, forem atingindo essa idade, que dará direito ao gozo imediato da liberdade.

A idade para este efeito será determinada pela matrícula, só se admitindo prova em contrário quando esta for em favor da liberdade.

$\S 4^{\circ}$ Os casados, desde que um dos cônjuges desonerar-se da obrigação de serviços por qualquer dos meios estabelecidos nesta lei. Havendo filhos, estes, quaisquer que sejam as condições em que se achem, acompanharão seus pais.

$\S 5^{\circ}$ Os libertos, durante o período da prestação de serviços, têm direito a salário, além de vestuário, alimentação e tratamento em suas enfermidades.

$\S 6^{\circ}$ Os ex-senhores que não cumprirem as obrigações impostas no parágrafo antecedente perderão o direito aos ditos serviços.

$\S 7^{\circ}$ As taxas e rendas destinadas ao fundo de emancipação serão empregadas em estabelecimentos de ensino profissional para os ingênuos e em asilos para os libertos valetudinários e inválidos.

621 Remetemos ao vivo relato de Angela Alonso sobre as ações clandestinas de abolicionistas ao longo dos momentos finais do cativeiro e a violenta repressão do Estado. Ibid., pp. 286-297.

622 Cf. Jeffrey D. Needell, "Politics, Parliament, and the penalty of the lash: The significance of the end of flogging in 1886". Almanack. Guarulhos, n. 04, 2 semestre de 2012, pp. 91-100. 
Art. $2^{\circ}$ Revogam-se as disposições em contrário. ${ }^{623}$

Mais de 30 deputados, destacando-se, além de alguns conservadores do Norte do país, os liberais eleitos por certas províncias, especialmente Minas Gerais, Ceará e Rio Grande do Sul (entre eles alguns membros da antiga dissidência antagônica ao ministério Dantas) votaram para que o projeto fosse considerado objeto de deliberação e enviado às comissões da casa. ${ }^{624}$ Apenas 41 conservadores, por sua vez, num universo de mais de 90, se manifestaram para impedir sua passagem. O projeto foi impedido de ir a plenário, mas por uma margem impensavelmente pequena, ao menos se se considerar como referência o antiabolicionismo que demonstrara o Partido Conservador nos anos anteriores. ${ }^{625}$

Menos de um mês depois, se evidenciou, na câmara alta, o quão rápido era o caminhar da questão. Secundado por treze correligionários, o conselheiro Dantas apresentou novo projeto de abolição da escravidão que, além de limitá-la ao final da década de 1880 , resgatava o plano de concessão de terras a libertos, presente no projeto apresentado em 15 de julho de $1884 .{ }^{626}$ Segundo Dantas, a apresentação de uma proposta com prazo bem mais curto do que aquela levada por ele ao Parlamento no ano anterior se justificava pelo rápido avanço da questão sobre a qual "até que a última palavra seja proferida, a ninguém é dado descansar". Mesmo se a lei de 1885 "tivesse tido leal e sincera execução", declarou o senador baiano, ela "não satisfaria as aspirações de todos". Fica claro, portanto, que, para alguns, ao menos, o projeto de 15 de julho de 1884, passado um ano, já se encontrava defasado e que o projeto apresentado pelo próprio Dantas, em 1886, que previa a libertação de todos os escravos do Império em cinco anos, já era "atrasado" em 1887. ${ }^{627}$ Era preciso que se desse um fim rápido à "instituição maldita", que barrava o "progresso" do país:

A Assembleia Geral resolve:

Art. $1^{\circ}$ Aos 31 de dezembro de 1889 cessará de todo a escravidão no Império.

$\S 1^{\circ}$ Está em vigor em toda a sua plenitude e para todos os seus efeitos a lei de 7 de novembro de 1831 .

$\S 2^{\circ}$ No mesmo prazo ficarão absolutamente extintas as obrigações de serviços

623 O projeto foi apresentado em 4 de maio. ACD. Sessão de 1887, tomo I, p. 8.

$624 \mathrm{O}$ único deputado liberal que se manifestou contra o projeto foi Lourenço de Albuquerque. Ibid., p. 8.

625Um ano antes, Manuel Francisco Correia, senador conservador que não era das figuras mais "emperradas"

de seu partido (ao menos quando se tratava da emancipação dos escravos), declarara a Saraiva: "No que respeita à extinção da escravidão, o meu voto é que se realize antes do novo século, ou, para melhor dizer, que o novo século comece, nesta parte, já sob o regime que tem de durar em quanto [sic] existir a nacionalidade brasileira”. Manuel Francisco Correia ao conselheiro Saraiva, 10/02/1886. AIHGB. Col. Saraiva, DL 274.11.

626 Para a apresentação do projeto, ver: AS. 03/06/1887, pp. 14-18.

627 Ibid., p. 15. 
impostos como condição de liberdade e a dos ingênuos em virtude da lei de 28 de setembro de 1871.

$\S 3^{\circ} \mathrm{O}$ governo fundará colônias agrícolas para educação de ingênuos, e trabalho de libertos, à margem dos rios navegados, das estradas ou do litoral.

Nos regulamentos para essas colônias se proverá a conversão gradual do foreiro ou rendeiro do Estado em proprietário dos lotes de terra que utilizar a título de arrendamento.

Art. $2^{\circ}$ Revogam-se as disposições em contrário. ${ }^{628}$

A posição antiescravista do Partido Liberal havia se fortalecido, então, tanto na Câmara quanto no Senado. No ramo temporário, as eleições extemporâneas ocorridas entre 1886 e 1888, por motivo de falecimentos de deputados, nomeações ao Senado ou de ministros, cujas vagas deveriam ser objeto de novo escrutínio, foram majoritariamente vencidas por liberais. Isto significou que, até meados de 1888, a bancada do partido oposicionista na Câmara teve um acréscimo de cerca de dez deputados. ${ }^{629}$ No ramo vitalício, as fissuras no Partido Conservador quanto à política de Cotegipe sobre a escravidão permitiram que os liberais ganhassem musculatura nos ataques ao gabinete. ${ }^{630}$ Nas províncias, por sua vez, há indícios de seguidas vitórias liberais nas eleições para as Assembleias Legislativas locais. ${ }^{631}$ Como veremos na seção seguinte do presente capítulo, quando a abolição se mostrou inevitável, os liberais parecem ter tido um papel de peso para que fosse imediata e incondicional. ${ }^{632}$

Com o fim do cativeiro, e mediante as profundas divisões que atravessavam as fileiras adversárias, especialmente no que dizia respeito à indenização aos senhores "espoliados" pela Lei Áurea, o Partido Liberal pôde iniciar a tentativa de uma rearticulação

628 Ibid., p. 18. Além de Silveira da Mota, Franco de Sá, Francisco Otaviano, Henrique d'Ávila, Joaquim Raimundo de Lamare, Liberato de Castro Carreira e visconde de Pelotas, que haviam assinado o projeto de 1886, deram seu apoio à nova iniciativa os senadores Afonso Celso, Gaspar da Silveira Martins, Inácio Martins, Lima Duarte, Lafaiete Rodrigues Pereira e Cândido de Oliveira, recém-nomeado para a câmara vitalícia. Eram, portanto, um representante da Bahia, um do Maranhão, um do Ceará, um do Mato Grosso, um do Rio de Janeiro, um de Goiás, três do Rio Grande do Sul e cinco de Minas Gerais.

629 Um caso emblemático foi a vitória de Nabuco sobre o recém-nomeado ministro do Império, Machado Portela, no $1^{\circ}$ distrito de Pernambuco, em fins de 1887. Foram também significativas as vitórias dos liberais abolicionistas César Zama e Elpídio Pereira de Mesquita, na Bahia, e Manuel Rodrigues Peixoto, no Rio de Janeiro, em eleições ocorridas no primeiro semestre de 1888. Cf. Barão de Javari, op. cit., pp. 391-401.

630 Cf. Jeffrey D. Needell, "Politics, Parliament, and the penalty of the lash", pp. 96-97.

631 Segundo o deputado mineiro Afonso Pena, entre 1887 e 1888, "o partido liberal ganhou a eleição em maior número de províncias". ACD. 05/06/1888, p. 47.

632 Como se verá mais adiante, mediante a análise das divisões do Partido Conservador quanto ao emancipacionismo do ministério João Alfredo, nomeado em março de 1888, é possível perceber que os liberais, especialmente a partir do Senado, conseguiram garantir que não haveria contrapartidas aos libertos após a extinção do cativeiro (como, por exemplo, prestação de serviços) e que to projeto de libertação fosse apresentado o mais rápido possível, sem a discussão de outras medidas que organizassem o trabalho o precedendo. 
programática a nível nacional, continuamente ensaiada, nas províncias e no Parlamento, ao longo dos anos anteriores, mas adiada pela questão servil, que "assoberbava todos os espíritos". A necessidade de uma extinção rápida do trabalho escravo advinha, para além de seu objetivo próprio, do fato de que os projetos defendidos por setores crescentes do Partido Liberal (ao longo da segunda metade da década de 1880), de caráter igualitário, inclusivo e avesso a hierarquias, eram hostis ao escravismo, defendendo uma ruptura total com a lógica social e política por ele encetada e uma integração rápida de libertos e ingênuos à sociedade, por meio da expansão dos direitos de cidadania e, mesmo, da facilitação do acesso à terra.

Ao longo dos meses imediatamente posteriores à Lei Áurea, mostrava-se mais evidente a busca de um compromisso interno no partido em torno de reformas percebidas como urgentes para a renovação da monarquia brasileira, frente à profunda conflagração social que o violento processo de colapso da escravidão gerara no país. Se se faziam ouvir "vozes ruidosas, que querem, por assim dizer, transformar profundamente a ordem política e social do Império", declarava Cândido de Oliveira, a neutralização das ameaças às instituições se daria pelo "mais largo desenvolvimento do pensamento liberal", por meio de "ideias francamente liberais, vazadas nos moldes da mais ampla democracia". Assim sendo, o senador mineiro listou a gama de reformas necessárias para a restauração da estabilidade do Império sobre um solo definitivamente liberal e democrático, antecipando os pontos fundamentais que só a união do partido poderia transformar em um programa reformista coerente:

É preciso enveredarmos franca e decididamente pela senda da liberdade a mais ampla, em todas as suas ramificações; da liberdade política, pelo alargamento do voto...

O Sr. Dantas: - Apoiado.

O Sr. Cândido de Oliveira: - ... da liberdade civil, pela concessão das mais completas regalias e garantias do cidadão, tanto para sua pessoa quanto para seus bens; da liberdade administrativa pela supressão dos entraves com que estão cercadas as relações entre o governo e seus jurisdicionados; e, sobretudo, é necessário restituir às províncias os seus direitos, conculcados [sic] pela mais atrofiadora das centralizações. ${ }^{633}$

Deste modo, num contexto de profundas alterações no tecido social e na política do

633 AS. 25/05/1888, p. 97. Grifo no original. Cândido de Oliveira fazia tais considerações em discurso de defesa da promulgação de uma nova, e mais abrangente, lei de Habeas Corpus, defendida pelos liberais, junto da restauração das disposições originais do Código de Processo Criminal, reformado pelo Regresso nos anos 1840. 
país, em que a ala mais radicalizada do Partido Liberal ganhava uma proeminência sem precedentes, até mesmo os mais recalcitrantes não podiam deixar de reconhecer a necessidade de que o programa reformista da agremiação fosse reavaliado e rearticulado frente ao crítico estado de coisas. A união do partido e qualquer esperança de seu retorno ao poder estavam necessariamente ligadas à apresentação de uma alternativa à situação conservadora, cuja "esterilidade", ${ }^{634}$ dadas as divisões no partido adversário, parecia insuperável. Esta intrincada conjuntura, em que camadas crescentes da população exigiam participação nos negócios públicos, tornou-se um diagnóstico comum entre grande parte da elite política imperial, transformava a reforma da lei eleitoral (com expansão do sufrágio) na mais urgente das reformas

Ela, de fato, se tornou a primeira bandeira do Partido Liberal, que, sob a liderança de Afonso Celso de Assis Figueiredo, já visconde de Ouro Preto, passou a publicar na Corte um jornal a fim de apresentar à opinião pública os movimentos do partido e unir suas diferentes tendências na preparação de um congresso no qual se votaria um novo programa. Nos primeiros números da Tribuna Liberal, foram destacadas as reformas pretendidas. ${ }^{635}$

Comparando o conturbado momento pelo qual passava o país com aquele dos anos 1830, em que o Partido Liberal, por meio do Ato Adicional, argumentava o editorialista, havia sido capaz de salvar as instituições, defendia-se que o sucesso da emenda constitucional fosse utilizado como exemplo para que, sem golpes de Estado, sem ameaças às instituições, ressurgisse seu "espírito", como consequência lógica das aspirações populares após o 13 de maio. O "mecanismo" do Ato, alegava a folha, "não exclui, e ao contrário garante, a realização das mais largas aspirações dos que almejam" ver a nação "independente e poderosa, consorciando a liberdade do cidadão e a autonomia do município e da província com a integridade e a solidariedade nacionais". Reivindicando como essencial a "restauração do regime democrático", o jornal expunha os objetivos que

$634 \mathrm{O}$ termo foi usado pelo liberal pernambucano Antônio de Siqueira, que declarou estar reconciliado com “o Nabuco e seus amigos". Antônio de Siqueira a Luís Filipe de Sousa Leão, 19/08/1888. AIHGB. Col. Sousa Leão, DL 456.160.

635 Assinaram um comunicado sobre o motivo do lançamento da folha e os pontos principais do programa reformista pretendido, endereçado aos "diretórios do partido nas províncias e no município neutro", os seguintes senadores: visconde de Sinimbu, visconde de Lamare, José Inácio Silveira da Mota, Liberato de Castro Carreira, Cândido Luís Maria de Oliveira, Felipe Franco de Sá, Francisco de Carvalho Soares Brandão, Gaspar da Silveira Martins, Henrique Francisco d'Ávila, Inácio Antônio de Assis Martins, João Ernesto Viriato de Medeiros, João Florentino Meira de Vasconcelos, José Rodrigues de Lima Duarte, Luís Filipe de Sousa Leão, Pedro Leão Veloso, Francisco Otaviano de Almeida Rosa, Lafaiete Rodrigues Pereira, Manuel Pinto de Souza Dantas, marquês de Paranaguá e visconde de Ouro Preto. Tribuna Liberal. 01/12/1888, p. 1. 
deveriam estar contidos num autêntico programa liberal, a começar, como já foi observado, pela expansão do sufrágio:

$\mathrm{Na}$ ordem política cabe a prioridade ao alargamento do voto. A massa geral dos cidadãos tem o direito de intervir no governo do Estado, que presentemente corre à sua revelia; é mister conferir o sufrágio eleitoral a todos os brasileiros que saibam ler e escrever. Esta é a base imprescindível de quaisquer outros propósitos. Sobre tais alicerces firmar-se-á segura e inabalável a reorganização dos municípios e das províncias, plenamente livres na respectiva esfera de ação, só limitada no que possa afrouxar os elos da comunhão. ${ }^{636}$

A real participação popular na eleição do Poder Executivo nas províncias era, por sua vez, colocada como essencial para o alargamento de sua esfera de ação, da mesma forma que uma melhor distribuição dos impostos, aumentando os recursos deixados às províncias e localidades, de modo a permitir sua mais adequada gestão e aplicação. O texto seguia elencando outros pontos que deveriam ter prioridade, caso se desejasse o "adiantamento" do país:

A par destas medidas capitais, cumpre remover os três maiores obstáculos ao adiantamento do país: as distâncias, facilitando-se os meios de transporte; o deserto, povoando-se o seu vasto território; e a ignorância das classes populares, difundindo-se o ensino, máxime o primário, afiançado na lei fundamental. ${ }^{637}$

Tendo em vista tais considerações, o programa explicitava serem necessárias a garantia à liberdade religiosa, a facilitação na aquisição da terra, o incentivo à expansão da iniciativa individual, bem como a diversificação da base econômica do país. Deste modo, os líderes do partido conclamavam seus correligionários a levarem as preocupações principais das diversas regiões do Império ao Congresso na Corte, onde seria possível encontrar os pontos de consenso para a definição do programa nacional.

No início de maio de 1889, reuniram-se na cidade do Rio de Janeiro cerca de setenta delegados das diferentes províncias. Assumindo inicialmente a presidência do Congresso, o conselheiro Dantas “convidou para ocupá-la definitivamente o sr. visconde de Sinimbu, ao que, por unanimidade aquiesceram os membros presentes". ${ }^{638}$ Após as formalidades, inciaram-se os discursos.

636 Ibid., p. 1

637 Ibid., p. 1

638 Diário de Notícias. 02/05/1889, p. 1. 
Dantas foi o primeiro a orar. Afirmando que a melhor resposta ao crescimento do republicanismo era a adoção de um programa de largas reformas para o Império, o senador baiano declarou ser "ponto assentado aspirar o partido liberal ao máximo das liberdades compatíveis com a monarquia democrática, aquela que repousa na soberania do povo e na qual todos os poderes são delegações da nação". Afastar-se de suas origens e "romper com as instituições democráticas" ao não procurar aperfeiçoá-las seria, para Dantas, "um erro gravíssimo e que breve reduziria a nossa pátria ao estado de uma grande árvore de frondosa copa, mas sem raízes sólidas", sujeita, por isso, "a tombar por terra ao primeiro sopro da tempestade". 639

Ao senador baiano sucederam-se dois delegados de São Paulo. Gavião Peixoto destacou a necessidade da adoção de uma bandeira federativa para neutralizar as tendências republicanas em sua província. O Partido Liberal de São Paulo, observou o orador, já havia dado este passo, tendo em vista que o congresso provincial realizado anteriormente havia lançado o programa da federação. "Somente com tal política, larga e generosa, apoiada pela monarquia, ou mesmo contra ela poderá prolongar-se, tirando-se a razão do partido republicano", asseverou o delegado paulista. ${ }^{640}$ Moreira de Barros, também defendendo a federação, levantou-se, por sua vez, para retificar uma das proposições de Gavião Peixoto: "nas deliberações do partido em São Paulo", assegurou o orador, "sempre se julgou essencial a forma monárquica", não havendo sentido em falar-se de federação "contra a monarquia". 641

Declarando "aderir à proposta do Sr. Gavião Peixoto", Rui Barbosa observou, por sua vez, ser ociosa a retificação de Moreira de Barros. Claro estava, para o delegado da Bahia, que no momento em que a monarquia deixasse de ser o veículo das liberdades públicas, perderia "por isso mesmo a sua razão de existir". Outro delegado baiano, Manuel Vitorino Pereira, salientou a necessidade de que os chefes do partido procurassem satisfazer os "desejos da maioria dos liberais", realizando reformas entre as quais se destacava a temporariedade do Senado, “de que resultará a permanência dos chefes nas províncias que

639 O resumo das falas no Congresso foi reproduzido por Luiz Henrique Dias Tavares (org.), Ideias políticas de Manuel Vitorino. Rio de Janeiro: Fundação Casa de Rui Barbosa, 1981, v. 1, pp. 66-69.

$640 \mathrm{O}$ congresso do Partido Liberal paulista, realizado em meados de 1888, com a presença de destacados políticos da província, decidiu pela redação de um programa de governo federal inspirado nos Estados Unidos, com a manutenção do Imperador na chefia do Estado. Cf. Evaristo de Moraes, Da Monarquia para a República (1870-1889), São Paulo: Athena, 19--, p. 111. É bom lembrar que José Bonifácio, o Moço, e seu irmão, Martim Francisco, lideranças preeminentes do partido na província já haviam falecido, então.

641 Cf. Luiz Henrique Dias Tavares (org.), op. cit., p. 68. 
representam, e cujas necessidades assim melhor conheceriam", ${ }^{642}$

Após orarem alguns outros delegados, foi aclamada uma comissão encarregada de dar parecer sobre "Questões a estudar" a partir das propostas levantadas pelos membros do Congresso, incluindo a federalização da monarquia sugerida por Gavião Peixoto. Tal comissão foi formada por representantes do Maranhão, da Bahia, de São Paulo, de Minas Gerais, de Alagoas, do Rio Grande do Sul e do Rio de Janeiro; respectivamente, Franco de Sá, Leão Veloso, Rui Barbosa, Moreira de Barros, Carlos Afonso, Lourenço de Albuquerque, Francisco Antunes Maciel, Eduardo Andrade Pinto e Francisco Luís da Gama Rosa. ${ }^{643}$ Entre as principais “Questões a estudar" estavam as seguintes:

$1^{a}$ Convirá aceitar, como expediente de ocasião, para arregimentar os partidos, o projeto que, segundo consta, apresentará o governo [João Alfredo] para o escrutínio de lista, contanto que ele, por sua vez, aceite o alargamento do voto nos termos do que vai junto [sufrágio para todos os alfabetizados], ou ainda com alguma restrição, desde que amplie mais o mesmo voto do que a lei de 1881 ?

$2^{\text {a }}$ Convirá abolir o escrutínio secreto?

$3^{\text {a }}$ Convirá promover primeiro a restauração e desenvolvimento do Ato Adicional ou propor simultaneamente a reforma das presidências de província?

$4^{\mathrm{a}}$ Privar o Poder Executivo da nomeação desses funcionários não é contrariar o art. 165 da Constituição do Império, e, conseguintemente, tornar a reforma dependente dos trâmites constitucionais? ? $^{644}$

À primeira das perguntas, a comissão respondeu que os representantes liberais deveriam negar apoio a qualquer projeto apresentado pelo governo, já que este não apenas não lhe merecia confiança, como cabia que "cada credo político governasse e legislasse de acordo com seus princípios”. Do contrário, a confusão de ideias poderia potencialmente levar o Partido Liberal a se afastar de posições que convinham à estabilidade institucional.

Quanto à segunda questão, considerou-se urgente o alargamento do voto para todos os cidadãos alfabetizados, o que teria a vantagem de estimular a difusão do ensino primário. Além disso, era imprescindível não apenas a manutenção do voto secreto, mais também cercá-lo de mais proteção. Já a forma da eleição, por voto distrital uninominal ou por listas,

642 Ibid., p. 69.

643 Ibid., p. 69.

644 Tribuna Liberal. Maio de 1889 [s. d.]. AIHGB. Col. Ouro Preto, L. 427 P. 2. O artigo 165 da Constituição de 1824 dispunha: "Haverá em cada Província um Presidente, nomeado pelo Imperador, que o poderá remover, quando entender que assim convém ao bom serviço do Estado". 
dependeria das circunstâncias políticas em que o país se encontrasse.

Às duas últimas questões citadas se respondeu que a reforma da administração provincial seria possível sem trâmites constitucionais, se não se extinguisse por completo a intervenção do centro na nomeação dos presidentes de província. Apesar de a maioria da Comissão preferir a eletividade desses funcionários, "isto daria lugar à questão da necessidade de uma Câmara Constituinte ou Revisora, e sendo urgentíssima a necessidade da reforma descentralizadora, concorda com a solução indicada nos quesitos da $4^{\text {a }}$ questão". Deste modo, o parecer indicava que a nomeação dos presidentes de província deveria ser precedida de uma eleição em que os três mais votados passariam pelo crivo imperial, um deles sendo designado ao cargo, e cabendo aos outros dois a vice-presidência. Nesse sentido, julgava a comissão ser "conveniente que a administração provincial seja separada da geral, sendo o presidente somente encarregado do poder executivo provincial", ficando, deste modo, "os serviços gerais a cargo dos chefes das respectivas repartições nas províncias", como inspetores da tesouraria geral e da alfândega, comandante das armas, capitães de portos, administradores dos correios, entre outros, que "serão imediatos agentes do poder central, como já hoje o são quase completamente, e aos quais competirão todas as atribuições necessárias, para a desconcentração desses serviços”.

Nessa nova divisão de competência, o presidente permaneceria sendo, todavia, "a primeira autoridade da província”, tendo o direito de suspender qualquer empregado geral que "desacate a autoridade ou invada as atribuições dos poderes provinciais, submetendo o seu ato ao respectivo ministro". Além disso, o governo imperial "poderá dirigir-se ao presidente da província para lhe pedir quaisquer informações, incumbi-lo de comissões especiais, e recorrer à sua autoridade a bem da defesa do Império e da guarda da Constituição e das leis". Em caso de rebelião ou invasão de inimigos, a intervenção do poder central também estaria prevista. ${ }^{645}$

Prioridades fundamentais eram também a temporariedade do Senado, a reforma do Conselho de Estado, garantias eficazes ao direito de reunião e à liberdade de expressão, assim como a liberdade e melhoramento do ensino. Entre as outras considerações apresentadas pela comissão, estavam, ainda, a questão fiscal, com a defesa da transferência das prerrogativas sobre certos impostos gerais às assembleias provinciais; a atribuição a tais assembleias para a realização da reforma municipal, desde que respeitado o princípio de autonomia municipal; a urgência da decretação da liberdade de cultos e do casamento 
civil obrigatório, tendo em vista a necessidade de atração de ampla corrente imigratória; e, finalmente, a diminuição ou abolição dos impostos de exportação para auxiliar a agricultura nacional. ${ }^{646}$

A partir das proposições da comissão, foi formulado um programa para o Partido Liberal concorrer às eleições seguintes. ${ }^{647} \mathrm{O}$ primeiro ponto do programa gravitava, seguindo a comissão, em torno do alargamento do voto, cujo direito deveria ser estendido a todos que soubessem ler e escrever. Além disso, previa-se a manutenção do "escrutínio secreto", bem como a aumento do número de deputados "proporcionalmente à população ou ao eleitorado". Dispunha-se, ainda, que o Município Neutro formaria "circunscrição eleitoral separada, tanto para deputados, como para senadores". 648

O segundo ponto do programa dizia respeito à reforma da administração provincial. Além do presidente "nomeado pelo imperador, dentre os cidadãos eleitos em lista tríplice, de quatro em quatro anos", previa-se que os outros dois nomes mais votados seriam vicepresidentes. Estabelecendo os casos em que tais funcionários poderiam ser destituídos ou suspensos, bem como as incompatibilidades ligadas a seus cargos, ditava-se que uma lei provincial poderia determinar a criação de um "conselho, deliberativo ou consultivo", responsável por "auxiliar" o presidente no exercício do Poder Executivo. Restaurando-se, ainda, "em sua plenitude o regime descentralizador do Ato Adicional", pretendia-se garantir às províncias o máximo de autonomia, "sem ofensa aos interesses gerais da nação". Aumentava-se os recursos pecuniários à disposição das assembleias provinciais e cedia-se a elas as prerrogativas sobre as câmaras municipais. A exceção seria a capital do Império, onde, "em vez de Câmaras Municipais, haverá um conselho legislativo, com as atribuições das Assembleias Provinciais”. Na Corte, se criaria ainda a figura do prefeito, nomeado do mesmo modo e tendo as mesmas atribuições que os presidentes de província. A estes seria ainda atribuída a faculdade de suspender provisoriamente qualquer funcionário da administração geral "que na província desacatar a autoridade ou usurpar atribuições dos poderes provinciais; submetendo imediatamente seu ato à aprovação do governo imperial". 649

O terceiro ponto visava a garantir o pleno direito reunião, enquanto o quarto e quinto pontos instituíam o casamento civil obrigatório e a "plena liberdade de cultos". O sexto

646 Ibid.

647 Diário de Notícias. 24/05/1889, p. 2.

648 Ibid., p. 2

649 Ibid., p. 2. 
ponto previa a temporariedade do Senado, com mandatos de nove anos e renovação da casa "pela terça parte de três em três anos". Da reforma do Conselho de Estado, para "que seja somente auxiliar da administração e não político", e da "liberdade e melhoramento do ensino" tratavam os pontos seguintes. O programa se encerrava listando outras providências julgadas de "urgente necessidade":

- Abolição ou a máxima redução possível dos direitos gerais de exportação;

- larga imigração, mas com as cautelas precisas para que realmente aproveite a produção nacional, e não sirva de pábulo [sic] à especulação e descrédito do país;

- lei que facilite a aquisição de terras públicas, permitindo a pronta colocação de operários nacionais e estrangeiros;

- criação de estabelecimentos de crédito que proporcionem à lavoura os recursos necessários;

- redução de fretes e desenvolvimento dos meios de rápida comunicação, conforme um plano previamente combinado e em que sejam atendidas somente as grandes e reais conveniências públicas. ${ }^{650}$

Um dos membros da comissão, no entanto, não sufragou o projeto apresentado. Dando voto em separado, Rui Barbosa justificou seu procedimento, declarando-se "completamente pela forma federativa" e observando ser o "sistema do questionário" uma "transação, que de modo nenhum satisfaz às atuais aspirações do país, nem contrapõe ao movimento republicano um regime capaz de neutralizá-lo, estabelecendo a descentralização na medida indispensável aos direitos do interesse local”. Para não ficar "aquém" do que esperava o país, o político baiano apresentou um projeto cuja base fundamental era a eleição por sufrágio direto de presidentes e vice-presidentes de província, sem intervenção do centro, bem como a eleição direta de senadores e a manutenção do voto distrital uninominal para deputados. ${ }^{651}$ Elencou, ainda, as bases para a organização federal do Império, determinando as competências de centro e partes. ${ }^{652}$

650 Ibid., p. 2.

651 Ibid., p. 2. No último caso, o voto em separado dispunha que "[a]o número de deputados correspondente ao dos círculos eleitorais existentes no império acrescerão mais trinta, os quais se elegerão pela soma dos votos obtidos no país inteiro, considerado como um colégio só, mediante apuração geral, reputando-se eleitos os trinta candidatos que maior adição de sufrágios reunirem das minorias na totalidade das eleições de distrito". Aparentemente, Rui Barbosa desejava estabelecer de uma vez por todas o regime puramente parlamentar, garantindo às minorias uma representação adicional e nacionalmente qualificada, tornando mais factível à oposição eleger bancada majoritária e promover a alternância de partidos no poder apenas pela composição da Câmara dos Deputados.

652 À "autoridade nacional”, competiria "prover às despesas da nação mediante as contribuições necessárias, diretas e indiretas, a venda e locação de terras de domínio nacional", entre outros. Competiria, ainda, regular o comércio com as nações estrangeiras, levantar empréstimos sobre o crédito do Estado, administrar os correios e as vias de comunicação interprovincial, cunhar a moeda e fixar seu valor, regular a propriedade literária, artística e industrial, criar instituições de ensino superior, dirigir a política 
Dos então presentes, 19 sufragaram o voto em separado de Rui Barbosa, enquanto 39 o rejeitaram, optando pelo parecer da comissão. ${ }^{653}$ Os apoios ao delegado vieram especialmente de sua província natal e de outras duas, São Paulo e Minas Gerais. Da Bahia, além do próprio Rui Barbosa, cinco delegados se mostraram favoráveis ao voto em separado; ${ }^{654}$ de São Paulo, foram quatro adesões; ${ }^{655}$ e de Minas, outras três. ${ }^{656}$ Todas as províncias se mostraram, no entanto, divididas na questão. ${ }^{657}$

Manuel Pinto de Souza Dantas, favorável à federação, realizou um discurso conciliador. Mesmo considerando esta "reforma como medida conservadora das instituições fundamentais e tendente a consolidar a integridade do Império", o senador baiano destacou existirem em todos os partidos "convicções individuais e deliberações coletivas", não impedindo isto que, mantendo suas ideias, cada um estivesse disposto "às transações necessárias para a obtenção de um resultado comum”. Isto significava que a adesão ao programa do partido não vedava a seus "membros mais adiantados" que continuassem a "pugnar pelas conquistas liberais que ficaram além dos limites firmados no compromisso coletivo". ${ }^{658}$ Não obstante as palavras de Dantas, as divisões internas no Partido Liberal em torno do problema da federação se manteriam relevantes nos meses seguintes, colocando muitos de seus membros numa posição recalcitrante com relação ao ministério Ouro Preto, que chegaria ao poder poucas semanas depois de findo o Congresso Liberal, apresentando ao país um programa de reformas baseado no texto majoritariamente

externa, levantar e manter Exército e Armada, criar províncias ou subdividir as existentes, bem como organizar o poder legislativo e a administração das províncias. À autoridade provincial, por sua vez, competiria, além "do que estabelece o Ato Adicional, todos os poderes não compreendidos nas atribuições da autoridade nacional e não contrários aos direitos constitucionais dos cidadãos, e bem assim as nomeações dos juízes singulares". Deste modo, salvo "os impostos que por lei geral se reservarem ao orçamento do império, a exportação, que não é tributável, e as taxas sobre o comércio, o trânsito e a navegação interprovincial, que ficam vedadas, cada província estabelecerá independentemente o seu sistema de contribuições". O programa defendia também a total secularização do ensino. Ibid., p. 2.

653 Tribuna Liberal. 24/05/1889, p. 1.

654 Eram estes o senador Dantas, Manuel Vitorino Pereira, Elpídio de Mesquita, Aristides Spinola e César Zama. Diário de Notícias. 24/05/1889, p.3.

655 Além do senador Francisco Antônio de Souza Queiroz e de seu filho homônimo, se pronunciaram nesse sentido Gavião Peixoto e Antônio José Ferreira Braga. Ibid., p. 3.

656 João da Mata Machado, José Cesário de Faria Alvim e Custódio José Ferreira Martins foram os delegados mineiros que votaram pelo texto de Rui. Ibid., p. 3.

657 A maior parte dos mineiros, como o visconde de Ouro Preto e seu irmão, Carlos Afonso, do mesmo modo que Benedito Valadares e Afonso Pena se mostraram a favor do parecer original. Em São Paulo, Moreira de Barros, e na Bahia, Pedro Leão Veloso também rejeitaram o voto em separado de Rui Barbosa. Ibid., p. 2. É bom observar que Pernambuco também se dividia na questão. José Mariano e Joaquim Nabuco eram francamente federalistas, ao contrário dos chefes tradicionais do partido na província.

658 Ibid., p. 3 
votado por este Congresso.

Para se compreender as divisões em torno da questão federal, tendo em vista que ambos os pareceres apresentados não divergiam nos outros pontos, parece relevante atentar a outra questão, intimamente ligada à federal, em que as divergências entre os "neo-liberais" - setores mais radicalizados do partido, e que tinham em Dantas sua mais importante liderança - e liberais mais moderados parecem ter alcançado uma considerável clivagem nos anos finais da monarquia. Um discurso proferido pelo senador Pedro Leão Veloso que, como vimos, cunhara, irônica e criticamente, a expressão "neo-liberais" 659 e se colocara contra o voto em separado de Rui Barbosa, de quem dizia querer "exclui-lo" do Partido Liberal, ${ }^{660}$ proferido poucos meses depois da Lei Áurea, pode nos ajudar a iniciar a compreensão de tais clivagens. ${ }^{661}$

No discurso, Leão Veloso atacava a "propaganda abolicionista" que, após o 13 de maio, se empenhava "em alcançar dos poderes públicos medidas que tendam para o que chamam de democratização do solo". Para o senador baiano, não havia sentido em se proclamar tais ensejos, pois eles haviam de se realizar naturalmente, pelas "leis econômicas”. Desta forma, o abolicionismo, que deveria ter, para Veloso, terminado junto com o cativeiro, não tinha mais papel a cumprir na nova realidade do país, servindo apenas para disseminar as ideias de uma "política que, se não é de ódio a uma classe, é de demolição de uma ordem de coisas existentes, para levantar-se sobre as ruínas coisa nova". ${ }^{662}$ Aparteando seu comprovinciano, Dantas indicava, por sua vez, que a divisão do solo era uma consequência necessária da abolição, "que dará lugar a que haja também a pequena propriedade", pois "[i]sso agora é que é justo". ${ }^{663}$ É bom lembrar que o próprio projeto emancipacionista de 15 de julho de 1884, apresentado ao Parlamento pelo filho do senador baiano, ${ }^{664}$ bem como aquele lido pelo próprio conselheiro ao Senado, três anos depois, ${ }^{665}$ continham disposições para a fundação de colônias agrícolas de libertos que deveriam se transformar, gradualmente, em pequenos proprietários, ensaiando assim uma inciativa de democratização do acesso à terra. Nesse sentido, parece evidente uma considerável diferença de posições entre os dois correligionários e comprovincianos.

659 Leão Veloso a Saraiva, 07/03/1886. AIHGB. Col. Saraiva, DL 273.37, doc. 5. 660 Leão Veloso a Saraiva, 14/03/1886. AIHGB. Col. Saraiva, DL 273.37, doc. 6. 661 AS. 17/07/1888, pp. 187-191.

662 Ibid., pp. 188-189.

663 Ibid., pp. 188-189.

664 ACD. Sessão de 1884, tomo II, pp. 16-20.

665 AS. 03/06/1887, pp. 14-18. 
Ainda menos comedidos do que Dantas em sua defesa da "democracia territorial", é mais do que comprovado pela historiografia, os abolicionistas, muitos dos quais eram também "neo-liberais" ou "dantistas", não mediram palavras quando se tratou de defender projetos como o censo rural, o imposto territorial e a concessão de terras a libertos, mesmo que por meio da divisão das grandes propriedades. ${ }^{666} \mathrm{O}$ desconforto que tais projetos causavam nas figuras do Partido Liberal mais ligadas à grande lavoura, como Sinimbu, Moreira de Barros, Martinho Campos, entre outros, não parece poder ser subestimado.

Afonso Pena, um dos líderes da dissidência anti-Dantas em meados da década, em carta a Saraiva, datada do início de 1889, afirmava serem "pouco lisonjeiras" as circunstâncias em que se encontrava a província mineira. Com o trabalho "desorganizado" e fazendas abandonadas por libertos, o deputado liberal alegava que o governo imperial, à época chefiado por João Alfredo, não dava a atenção devida a Minas, fato que, conjuntamente com outras questões, contribuía para agravar seu abatimento:

A lavoura desanimada e profundamente sacrificada, sem fé nos partidos constitucionais, vai migrando para as fileiras da república. Os defensores da monarquia, como o Nabuco, m[ais] a comprometem, já assentando a cada passo o papel saliente da princesa na abolição, já indicando-a como o apoio dos que querem suplantar o suposto feudalismo territorial existente no país. ${ }^{667}$

Desejando suplantar o "feudalismo territorial" por meio de medidas como o "imposto territorial, nacionalização de terras e outras quejendas", Nabuco e seus aliados tornavam nada animadoras as perspectivas para aqueles lavradores que ainda se conservavam "fiéis à monarquia". Diante de tal estado de coisas, apenas com "uma política larga, reparadora, justa" que libertasse "as províncias da tutela da Corte" seria possível reconquistar o "espírito da lavoura mineira para as instituições", assegurava o representante de Minas Gerais. $^{668}$

Partindo do caso citado, é possível, portanto, aventar que o motivo para defensores da concessão de largas prerrogativas às províncias, como Afonso Pena, não aceitarem o programa federalista de Rui Barbosa, e tampouco aquele apresentado anteriormente por

666 Para diferentes abordagens da relação entre abolicionismo e questão agrária, ver, entre outros: Angela Alonso, Flores, Votos e Balas; Joselice Jucá, André Rebouças: reforma \& utopia no contexto do segundo império, Rio de Janeiro: Odebrecht, 2001; Maria Alice Rezende de Carvalho, O quinto século: André Rebouças e a construção do Brasil, Rio de Janeiro: Revan, 1998; Inoã Pierre Carvalho Urbinati, Ideias e projetos de reforma agrária no final do Império (1871-1889): uma análise de seu sentido político e social, Dissertação de Mestrado em História, Rio de Janeiro: UERJ, 2008.

667 Afonso Pena a José Antônio Saraiva, 01/01/1889. AIHGB. Col. Saraiva, DL 275.24. 668 Ibid. 
Joaquim Nabuco, ${ }^{669}$ estivesse no fato de que sua ideia de descentralização e alargamento das franquias provinciais fosse significativamente diferente das desses liberais mais extremados em, ao menos, um ponto, que se tornou mais sensível com a radicalização do abolicionismo: a questão fundiária. Por outro lado, a federalização do Império dependeria, segundo muitas das interpretações da época, como a do próprio Joaquim Nabuco, de uma Assembleia Constituinte, cujos resultados poderiam ser imprevisíveis, frente ao conflagrado momento social e político que vivia o país. ${ }^{670} \mathrm{~A}$ democratização política, portanto, que aceitavam talvez como inevitável não deveria ser rápida demais nem parecia estar necessariamente conjugada, para alguns setores do Partido Liberal, a uma imediata democratização social do país. ${ }^{671}$

Pelo que foi exposto até aqui, parece ser seguro indicar que, frente à violenta crise da escravidão e o processo de radicalização política e conflagração social do país, o Partido Liberal foi capaz, depois das batalhas intestinas de meados da década de 1880, de formular um projeto que tinha na superação rápida do escravismo seu alicerce. Aliando as bandeiras tradicionais do partido a um novo e avançado conteúdo democrático, fortalecido pela proeminência que ganhava a ala mais radical do partido, os liberais, em quatro anos de oposição, reformularam o programa da agremiação e apresentaram um projeto de país essencialmente reformista. Tal projeto, se jamais foi coeso, representou o resultado de um grande esforço político, encetando novas disputas acerca do destino da monarquia brasileira, assoberbada por uma crise institucional, política e social sem precedentes.

\section{2 - Autoridade e hierarquia}

Lhe direi [sic] com toda a sinceridade que as coisas aí não seguem caminho regular. Cotegipe está muito ferido e nunca mais poderá atingir as alturas que devia

669 Em 1888, Nabuco apresentara novamente, à Câmara dos Deputados, seu projeto federação por vias de reforma constitucional. Ele foi assinado por outros 17 deputados liberais. ACD. Sessão de 1888, tomo IV, p. 7.

670 É importante lembrar que o voto em separado de Rui Barbosa indicava pretender deixar ao Estado imperial o controle sobre as terras nacionais, diferentemente da Constituição republicana de 1891, que passaria as terras devolutas ao controle total das partes, recém-nomeados estados. Cf. Lígia Osório Silva, Terras devolutas e latifúndio: efeitos da lei de 1850 ( $2^{\mathrm{a}}$ ed.). Campinas: Editora da Unicamp, 2008, terceira parte "A terra da república".

671 Não parece coincidência, portanto, que os defensores mais arraigados do federalismo, entre os liberais mineiros que se opuseram ao ministério Dantas, tenham aderido, em sua maioria, ao republicanismo nos anos de 1888 e 1889, enquanto que a maioria dos "neo-liberais" e abolicionistas se mantiveram fiéis à monarquia até o fim. Aquele foi o caso de João Penido, Felício do Santos e Antônio Carlos Ribeiro de Andrada, por exemplo. Cf. George C. Boehrer, Da monarquia à república: história do Partido Republicano do Brasil (1870-1889), Rio de Janeiro: Ministério da Educação e Cultura, 1950. 
galgar. Tem incorrido em grandes faltas; interpretado certas leis e das mais vitais, mesmo com antipatia a mais evidente. Parece pelo que vejo de longe que ele se opõe a que seja bem executada a nova lei de emancipação.

Eu tenho o espírito, como você sabe, um pouco autoritário e portanto conservador; a meu ver o partido no poder devia procurar de [sic] aniquilar os elementos de anarquia e portanto fazer frente aos abolicionistas revolucionários, por consequência o seu dever era procurar de [sic] não anular os efeitos da lei do elemento servil. O Ministério Cotegipe está desprestigiado e com o tempo, não sei quando, será você o sucessor; pode bem avaliar que os meus sinceros votos são para que trilhe estrada larga a bem da Pátria comum $\left[\ldots . .{ }^{672}\right.$

Eram essas as impressões que, do exterior, Manuel Antônio da Rocha Faria, o visconde de Nioaque, manifestava acerca do contexto político brasileiro no segundo semestre de 1886. Observador atento, Nioaque apontava para a situação embaraçosa em que se encontrava o ministério Cotegipe e sua política escravista, considerada "emperrada" demais até mesmo por setores do partido do qual o experiente senador baiano fora declarado "pontífice máximo". Mais do que proféticas, as considerações do visconde revelavam um conhecimento arguto da política e dos políticos de seu país. Os motivos para que Nioaque revelasse tanta segurança na futura ascensão de João Alfredo, que de fato ocorreria cerca de um ano e meio após o envio da carta, estavam intimamente ligados não só à natureza da política adotada por Cotegipe, mas ao aprofundamento da já gravíssima conflagração social que a contraofensiva reacionária preconizada pelo gabinete causou no país.

Após a mudança da situação política em agosto de 1885 e a subsequente dissolução da Câmara dos Deputados, depois da aprovação da lei emancipacionista de 28 de setembro daquele mesmo ano, o Parlamento encerrou seus trabalhos à espera das eleições. No intervalo entre as sessões, menos de dois meses após a promulgação da lei, o ministro da Agricultura, Antônio da Silva Prado, procedeu à sua regulamentação, atribuição do Executivo. $^{673}$

Como vimos na seção anterior, o "Regulamento Negro" de Prado, repudiado furiosamente por figuras pertencentes a variados espectros políticos, teve como principal objetivo garantir o prolongamento da escravidão até ao final do século XIX, bem como relativizar importantes disposições da Lei dos Sexagenários, já abundantemente atacada por sua tibieza. Entre suas prescrições, destacavam-se de forma particularmente negativa

672 Visconde de Nioaque a João Alfredo Correia de Oliveira (particular), 26/08/1886. Arquivo Histórico do Museu Imperial (em diante, AHMI). Col. João Alfredo, Pasta Otávio Eugênio, doc. 36. 673 Para a regulamentação da lei, remetemos à análise de Angela Alonso, Flores, Votos e Balas, p. 273. 
aquela que adiava o início da depreciação anual do valor dos escravos para o primeiro semestre de 1887, quando estaria terminada a nova matrícula dos escravos, bem como a legalização indireta da propriedade servil que até então pudesse ser contestada com base da lei antitráfico de 1831 e, mais ainda, a reabertura do comércio de escravos entre o Município Neutro e a província do Rio de Janeiro, onde havia grande demanda por mão de obra cativa. ${ }^{674}$

As disposições draconianas do regulamento e a política autoritária e reativa de Cotegipe logo desagradaram setores moderados do Partido Conservador, a que pertencia o próprio ministro da Agricultura. Esses setores haviam concordado em secundar a política centrista de Saraiva, com a contrapartida de que este aceitasse que os adversários emendassem significativamente seu projeto de emancipação gradual, já distinto em pontos essenciais daquele apresentado ao Parlamento, no ano anterior, por Rodolfo Dantas. ${ }^{675}$ Ao fazer tal concessão, tendo em vista a radicalidade que ganhara a questão servil, o núcleo do partido pretendera recompor a política de emancipação conservadora iniciada em 1871, reconhecendo que, diferentemente da realidade de quatorze anos antes, passava a ser necessário estabelecer um prazo fixo e largamente aceito para o término do cativeiro. ${ }^{676}$ Deste modo, fazia-se necessário combinar uma lógica de gradualismo, e reconhecimento da legalidade e legitimidade da propriedade escrava existente, com o reconhecimento tácito de que, dentro de um certo período de tempo, sua condição seria transformada. Em outros termos, a escravidão não mais morreria de morte natural, como almejavam aqueles que até 1884, entre eles a imensa maioria do Partido Conservador, compreendiam a libertação do ventre como início, meio e fim do processo de emancipação, sujeita a, no máximo, algumas adaptações exigidas pelo tempo. ${ }^{677}$ Pelo contrário, a partir de 28 de setembro de 1885 tornou-se fato consumado que a escravidão seria extinta pela mão do legislador, que interviria mais uma vez em sua trajetória para impor-lhe um ponto final.

A Lei dos Sexagenários foi, portanto, uma lei formulada, emendada e aprovada para ser a última palavra no processo de emancipação. Contudo, antes mesmo de ser promulgada, ela já sofria ataques de setores da elite política nacional para quem seu texto constituía uma derrota relevante. Se, para os liberais ligados a Dantas, o projeto Saraiva

674 Ibid., p. 273.

675 Para o projeto de 15 de julho de 1884, ver: ACD. Sessão de 1884, tomo II, pp. 16-20. Para o projeto emancipacionista de Saraiva, ver: ACD. 12/05/1885, pp. 53-55.

676 Tal prazo, na letra final da lei, ficou estabelecido em treze anos. Apud Paulo Bonavides e Roberto Amaral, Textos políticos da história do Brasil (3 $3^{\mathrm{a}}$ ed.), Brasília: Senado Federal, 2002, v. 2, pp. 714-721. 677 Joseli M. N. Mendonça, op. cit., pp. 119-128. 
fora sempre uma aberração ou "capitulação escravista", ele também jamais fora bem quisto por aqueles que se encontravam no extremo oposto do espectro político. Segundo declarara o próprio Paulino de Souza, o mais obstinado dentre aqueles que constituíam a "altíssima trindade" conservadora, a lei de 1871 havia resolvido o problema servil e qualquer adição ou desvio de suas disposições eram ilegítimos. ${ }^{678}$ Não obstante sua contínua rejeição a novas medidas versando sobre o cativeiro, algumas figuras próximas a Paulino de Souza, incluindo seu primo Francisco Belisário, bem como alguns dos mais destacados membros de sua "legião", ${ }^{679}$ votaram pela aprovação da nova lei, numa evidente mudança de posição em relação aos meses anteriores. ${ }^{680}$ Mostraram-se menos intransigentes, ainda que um número significativo de conservadores tenha, direta ou indiretamente, se recusado a sufragar o projeto, caso do também obstinado Domingos de Andrade Figueira.

Era verdade que, para alguns desses deputados, respondendo diretamente aos interesses dos eleitores de seus distritos, apoiar uma lei emancipacionista poderia constituir algo próximo a um suicídio político. Não obstante todo o seu cabedal político, o próprio Andrade Figueira, representante de um dos distritos mais visceralmente ligados ao trabalho escravo no Império, ${ }^{681}$ privilegiou os interesses de seus eleitores e se desviou do caminho traçado pelos chefes políticos nacionais de seu partido. ${ }^{682}$ Paulino de Souza, por sua vez, a despeito de suas convicções pessoais, também sabia que, frente à inevitabilidade da nova reforma do "estado servil", não era possível responder com a pura e simples resistência. Além de estar em jogo a unidade do partido, a imensa "anarquia" que tomava conta do país era um dado de realidade que nem mesmo o herdeiro máximo da tradição saquarema poderia ignorar. Desta forma, ao reivindicar o poder para os conservadores ameaçando bloquear a passagem da lei pelo Parlamento, ${ }^{683}$ Cotegipe tinha em vista o controle sobre sua regulamentação e aplicação, um trunfo político com o qual poderia realizar a união do partido em torno de um projeto de consenso para o país, em que se definiria um prazo para

678 AS. 23/03/1885, pp. 81-87.

679 O termo foi utilizado por Afonso Celso de Assis Figueiredo. AS. 20/03/1885, pp. 68-70.

680 ACD. 13/08/1885, p. 553.

$681 \mathrm{O}$ deputado representava o $11^{\circ}$ distrito da província do Rio de Janeiro, com sede na cidade de Barra Mansa, área tradicional da cafeicultura do Vale do Paraíba fluminense. Gazeta de Notícias. 17/03/1881, p. 2.

682 Por sua vez, representantes conservadores do Ceará se dividiram na votação a lei, por considerarem-na muito "atrasada", tendo em vista o desenrolar da questão em sua província já emancipada. ACD. 13/08/1885, p. 553. Segundo indica Sérgio Ferraz, cerca de um terço dos deputados conservadores não sufragaram o projeto, considerando-se os que participaram da votação e os faltosos. Entre os liberais, a proporção foi ainda maior. Cf. Sérgio Eduardo Ferraz, op. cit., pp. 195-197.

683 Para o tema, ver a seção 2.3 da presente dissertação. 
o término do trabalho escravo, primando pela transição gradual, sem grandes abalos. A adesão de Paulino não parece ter significado outra coisa senão que tal prazo deveria ser o mais amplo possível e que se retiraria da lei aquilo que houvesse de mais adverso à manutenção da ordem então vigente, especialmente no que dizia respeito aos interesses de sua província.

Parece sólida, portanto, a hipótese de que a entrada de Francisco Belisário Soares de Souza numa pasta-chave do novo ministério conservador teve como contrapartidas as concessões que garantiam o prolongamento da escravidão até, ao menos, o fim do século, além, é claro, das previsões que anulavam as possibilidades de contestação legal da mão de obra servil, bem como asseguravam a reabertura do tráfico de escravos entre Corte e província do Rio de Janeiro. ${ }^{684}$ Por trás disso, havia a tentativa de se assegurar o triunfo de um projeto para o país que harmonizasse as fileiras do Partido Conservador, em momento de importante realinhamento das forças políticas. Era, nesse sentido, preciso conciliar a lógica do gradualismo e da legitimidade do cativeiro com a nova perspectiva de que centenas de milhares de escravos em um espaço de tempo delimitado tornar-se-iam livres, não pela mão "generosa" de seus senhores, aos quais em tal caso deveriam "gratidão", mas pela intervenção do Estado, o que cortava o vínculo entre senhores e escravos e colocava em novos termos a lógica da tutela e hierarquização social, bases fundamentais das perspectivas conservadoras para o pós-emancipação, fundamentalmente contrárias ao projeto de federalismo cidadão esposado pelos liberais.

Tendo em vista tais considerações, é possível sugerir que as discórdias latentes entre conservadores, existentes ao menos desde os embates políticos do início da década de $1870,{ }^{685}$ ganharam um significado ainda mais grave no decorrer do decênio seguinte. Se a opção pela lógica do gradualismo, da tutela e do reconhecimento da legalidade e legitimidade da propriedade escrava era compartilhada entre membros das várias tendências do partido, os desentendimentos parecem ter estado na maior ou menor rejeição da intervenção do Estado no cativeiro, bem como na extensão temporal do período de transformação do trabalho, preocupação subsidiária de cálculos baseados tanto nas distintas realidades materiais das diferentes regiões que representavam, quanto em posicionamentos político-ideológicos. Estas significativas desinteligências se transformaram em um verdadeiro abismo entre correligionários, diante da conflagrada 
realidade da segunda metade da década de 1880.

A situação de Cotegipe não fora sólida desde o início de seu governo. Como figura sobressaliente do Partido Conservador, o barão era dos poucos que tinha condições de angariar apoio de suas diferentes alas. A política dúbia do ministério de 20 de agosto de 1885, criticada duramente pelo visconde de Nioaque na carta citada, pode se explicar por tal vulnerabilidade. Por um lado, o presidente do Conselho precisava encetar o processo de extinção gradual do cativeiro, garantindo que fosse ordeiro e que apresentasse resultados; por outro, precisava torná-lo o mais indolor e comedido possível, num momento em que todas as atenções do país a ele se voltavam. A resposta de Cotegipe parece ter sido esvaziar o conteúdo da lei, na medida do possível, resistir às forças antiescravistas mais ou menos radicalizadas, criminalizando-as ostensivamente e formular um programa de reformas políticas e sociais que, simultaneamente, desviassem a atenção do problema servil e estabelecessem um arcabouço para o futuro pós-escravista, projetando para tal futuro não uma ruptura, mas a continuidade do status quo por outros meios.

Tais proposições parecem ser perfeitamente ilustradas por propostas apresentadas ao Parlamento, ao longo dos anos de 1886 e 1887, pelo ministério e seus aliados. Essas medidas evidenciavam uma política de reformismo conservador, sendo que algumas das propostas remetiam diretamente à política praticada pelos gabinetes "regressistas" ou "saquaremas" de meados do oitocentos, além de conterem disposições de caráter disciplinador, visando claramente à população liberta.

Em fins de julho, foi apresentado pelo ministro da Agricultura, Antônio Prado, um projeto que tratava da reforma da Lei de Terras de $1850,{ }^{686}$ promulgada inicialmente pelo ministério Monte Alegre. ${ }^{687}$ Para além de "ter em consideração particular os interesses da imigração", o projeto não parecia destoar em disposições essenciais da lei original, objetivando apenas torná-la mais eficaz. Em pontos fundamentais, como a facilitação do acesso à terra, o projeto mantinha a centralidade da compra e venda na aquisição do solo, bem como regras bastante rígidas para a transformação de posses em propriedades. No que dizia respeito à concessão gratuita de lotes de terras, ela só poderia ocorrer no caso das “terras devolutas situadas nos limites do Império com países estrangeiros, em zona de 50

686 ACD. Sessão de 1886, tomo III, pp. 12-15.

687Para a Lei de Terras, ver a importante análise de Márcia Maria Menendes Motta, Nas fronteiras do poder: conflitos de terras e direito agrário no Brasil de meados do século XIX. Rio de Janeiro: Arquivo Público/ Vício de Leitura, 1998. 
quilômetros", sob condições bastante restritivas, o que também remetia à lei de $1850 .{ }^{688}$

Foi ainda apresentado, no ano seguinte, por Samuel Wallace Mac-Dowell, ministro da Justiça, um projeto que previa a proibição do uso de armas por "vadios, vagabundos e desordeiros". ${ }^{689}$ Criminalizando, com penas de prisão, não apenas a ociosidade, mas também a "capoeiragem", o projeto era claramente repressivo. Seu artigo $1^{\circ}$ previa, para aqueles que usassem "de agilidade ou destreza corporal, conhecida por exercício de capoeira, para o fim de fazer ou provocar desordem, de ofender pessoa certa ou incerta", a condenação a penas de prisão com trabalhos forçados que variavam de acordo com a gravidade do "delito". A proposta ainda tornava mais rígidas diversas disposições da reforma judiciária de 20 de setembro de 1871.

Estes projetos conservadores ilustram um evidente compromisso com a transição segura, ordeira e gradual ao novo regime de trabalho, tendo como prioridade a garantia da lenta substituição do trabalho escravo. Eles não primavam, destoando dos projetos liberais, pela disseminação do acesso à terra ou pela universalização da cidadania. Pelo contrário, chegavam a ser, como no caso da segunda proposta citada, restritivos aos direitos civis. Este horizonte excludente de país que possuíam os conservadores ficou evidente quando o fracasso do gabinete Cotegipe se escancarou.

Depois de aprovada a Lei dos Sexagenários, a primeira grave adversidade política por que passou o ministério, que já lidava com o realinhamento do abolicionismo militante e que tivera que trabalhar para eliminar o projeto de abolição em cinco anos, apresentado por Dantas e citado no subcapítulo anterior, ${ }^{690}$ veio pelas mãos de José Bonifácio. Acusando o governo de dilatar irregularmente o prazo para o fim do cativeiro, além de inflar, de forma artificial, o valor dos escravos, o senador paulista denunciou o plano do governo de prolongar a existência da "instituição maldita" utilizando-se de todos os meios à sua

688 Além de serem cidadãos brasileiros ou "prometerem sua naturalização", maiores de 21 anos, os peticionários deveriam obrigar-se "a ocupar a terra diretamente por si, ou por seus herdeiros, no caso de morte, por espaço de 5 anos; a ter morada habitual, e a cultivar efetivamente, pelo menos, 10 hectares de terras de matas concedidas, e a manter, nas de campos de criação que represente capital equivalente, pelo menos, ao valor mínimo legal das terras concedidas". Mais ainda, os custos da medição das terras ficaria a cargo do concessionário e a falta de cumprimento das obrigações listadas, dentro do prazo de dois anos, "sujeitará o concessionário à perda da concessão, voltando as terras ao domínio e posse do Estado". ACD. Sessão de 1886, tomo III, p. 13. Segundo a interpretação de Inoã Urbinati, o projeto de reforma, "independentemente das reais intenções de seus autores" possuía dispositivos capazes de permitir o desenvolvimento da pequena propriedade. Contudo, destaca o autor, "quando contraposto ao modelo de reforma agrária pregado pelos abolicionistas" adquiria "um perfil mais conservador: não se fez referência direta, por exemplo, aos libertos, como possíveis beneficiários das medidas propostas”. Cf. Inoã Pierre Carvalho Urbinati, op. cit., pp. 140-141.

689 ACD. Sessão de 1887, tomo IV, p. 6.

690 AS. 01/06/1886, p. 8. 
disposição:

Todos os atos do ministério da Agricultura parecem dominados pelo pensamento superior de prolongar a instituição maldita até o último dia do século. $\mathrm{O}$ seu regulamento de 14 de Novembro de 1885, é a negação da lei; os seus avisos obedecem todos a essa intenção dilatória.

Transformando a data da lei em data arbitrária, escolhida pelo governo, S. Ex. garantiu a escravidão por mais um ano e meio, e deixou entrever essa preocupação ministerial de fazer coincidir o fim do século com o fim do cativeiro. Anunciar a libertação antes desse dia fora diminuir-lhe as glórias, em um país onde o mesmo domínio do homem pelo homem deve acabar como cerimônia convencional de um século que termina e de um século que desponta.

O município neutro, já com vida à parte para os efeitos do fundo de emancipação, foi incluído com infração da lei na província do Rio de Janeiro, amesquinhando assim o princípio do domicílio do escravo, abertas as portas da capital ao tráfico da mercadoria servil, e destarte criado um privilégio deplorável em favor de uma província, e dificultada a emancipação da corte, o mais fundo e mais certeiro golpe que se poderia dar na cruel instituição, aliás já vacilante em seus alicerces.

Não bastava tudo isso; era preciso ainda alterar o preceito da lei no que toca à matrícula, e transformar o máximo das tabelas em preço fixo, antes e depois de seu encerramento.

Foi assim que em 19 de março do corrente ano, dirigindo-se ao Sr. ministro da fazenda, para fazê-la constar ao coletor das rendas gerais do município do Carmo, $\mathrm{S}$. Ex. [Antônio Prado] decidiu que ao senhor do escravo competia, sem impugnação possível, dar o valor para a matrícula, contanto que não excedesse limites os definidos na tabela. ${ }^{691}$

Aproveitando-se da discussão sobre o orçamento do ministério da Agricultura, Bonifácio apresentou emendas que visavam a demolir os pilares do regulamento da Lei dos Sexagenários. Consciente de que, se apresentasse projeto separado sobre a questão, ele teria o mesmo destino que tivera aquele que Dantas tentara avançar, ${ }^{692}$ o senador paulista adotou uma estratégia diferente: com disposições que, na prática, cancelavam o regulamento da lei emancipacionista, os aditivos propostos pelo parlamentar liberal estavam necessariamente vinculados ao orçamento, o que tornava sua rejeição isolada impossível, colocando o governo numa situação embaraçosa. Isto porque uma postergação indefinida da aprovação do orçamento da Agricultura significava, em um momento decisivo, adiar algumas das medidas fundamentais para a transição pretendida ao trabalho

691 AS. 17/09/1886, pp. 169-170. Numa decisão do Executivo de março de 1886 o ministério da Agricultura "fixara" o valor dos escravos a serem dados para a matrícula no máximo previsto para suas respectivas faixas etárias, ao determinar que as declarações de preços feitas pelos senhores não passariam mais por arbitramento, sendo, na prática, aceitas sem contestação.

692 O projeto Dantas fora barrado por uma comissão especial da casa, composta majoritariamente por conservadores. AS. 07/06/1886, pp. 76-77. 
livre, inclusive no que dizia respeito aos auxílios à imigração, priorizados por Antônio Prado. Dispunham os aditivos:

$1^{\circ}$ A dedução anual do valor primitivo do escravo, nos termos do $\S 1^{\circ}$ do art. $3^{\circ}$ da lei n. 3270 de 28 de Setembro de 1885, contar-se-á da data da mesma lei.

$2^{\circ} \mathrm{Na}$ proibição do $\S 19$ do art. $3^{\circ}$ da lei n. 3270 de 28 de Setembro de 1885 , compreende-se o município neutro, como divisão administrativa separada.

$3^{\circ} \mathrm{O}$ valor do escravo declarado pelo senhor conforme o $\S 2^{\circ}$ do art. $1^{\circ}$ da lei de 28 de Setembro de 1885, antes de encerrada a matrícula, pode ser impugnado pelo coletor, e, se não houver acordo, proceder-se-á nos termos do $\S 7^{\circ}$ do art. $3^{\circ}{ }^{693}$

Apesar de condenados por Antônio Prado, ${ }^{694}$ os aditivos foram aprovados pelo Senado, numa demonstração da crescente fragilidade política do gabinete na câmara alta. Devido às alterações, o projeto de lei orçamentária teve de ser reenviado para apreciação dos deputados. Colocando a regulamentação da lei no terreno da confiança política, não houve alternativa senão reunir as duas casas do Parlamento numa votação de confiança ao governo.

Ciente de que um resultado negativo importaria necessariamente na queda do ministério ou na dissolução da Câmara dos Deputados e convocação de novas eleições, os conservadores se reuniram e, em sua imensa maioria, com exceção de alguns representantes do Ceará, votaram contra os aditivos. ${ }^{695}$ Contudo, se Cotegipe venceu, não deixou de sair ferido do episódio. A legitimidade da lei que resultara no compromisso suprapartidário ficou em xeque no momento em que uma parte do Parlamento tornou claro que desaprovava por completo os ordenamentos conservadores sobre a legislação e, portanto, a condução do processo de emancipação por este partido. Afonso Celso Jr. alertou o governo para que não cantasse vitória muito cedo. Triunfava no Parlamento, mas já estava condenado pelo país:

A Assembleia Geral vai declarar solenemente, dentro em pouco, que o governo interpretou fiel e lealmente a lei de 28 de Setembro de 1885! (Apoiados.)

693 AS. 17/09/1886, p. 173.

694 Afirmou o ministro da Agricultura longe estar de "impugnar a iniciativa das câmaras para a revogação de uma lei; mas o governo não pode de modo algum aceitar tais emendas nas atuais circunstâncias parlamentares, julgando descabidas em uma lei do orçamento medidas legislativas que tendem a alterar o pensamento da lei de 28 de Setembro de 1885. Essa lei proveio de uma transação entre os dois partidos políticos para resolver uma grande questão social; e, desejando o governo mantê-la, não pode aceitar em uma lei ânua a alteração dela em pontos importantes". Ibid., p. 174.

695 ACD. Sessão de 1886, tomo V, p. 15. Entre os liberais, apenas o representante de Alagoas, Lourenço de Albuquerque, mais uma vez, destacou-se de seu partido no voto favorável ao governo dos adversários. 
Diante de tal declaração façamos, senhores, o grande silêncio que uma voz notável qualificou a lição dos reis; façamos silêncio, a fim de que fique em tangível relevo que semelhante declaração vai resvalar fria, indiferente e sem eco no coração e na consciência do país! (Muitos apoiados. Muito bem; muito bem.) ${ }^{696}$

Era muito mais grave do que silêncio desaprovador o que o país reservava a Cotegipe. No ano de 1887, o velho estadista baiano sofreria as piores derrotas de sua vida política.

A rearticulação do abolicionismo, após o insucesso da "solução liberal" e a ascensão dos conservadores, foi marcada não só pela intensificação das ações diretas no campo, mas também por sua extrema radicalização. Em São Paulo, onde havia grande concentração de escravos, dado o rápido crescimento da cafeicultura, ${ }^{697}$ e no Rio de Janeiro, onde o braço cativo ainda era dominante na grande lavoura, ${ }^{698}$ o ano de 1887 assistiu a uma movimentação sem precedentes do antiescravismo radical. Fosse nas seguidas insurreições, fugas e atentados a vidas de senhores e feitores, praticados pelos próprios escravos, fosse nas incessantes atividades clandestinas dos setores populares do abolicionismo, a contestação generalizada à política do gabinete conservador se provou irrefreável.

Na província de Antônio Prado, a situação se agravou de tal maneira que, já em meados daquele ano, se iniciou um movimento generalizado por parte dos próprios fazendeiros para a libertação imediata dos escravos, com condição de prestação de serviços por um período previamente acordado. ${ }^{699}$ Pretendia-se, assim, impedir que o abandono das fazendas se intensificasse e ganhar algum tempo para reorganizar o trabalho e salvar a produção. Prado, nomeado senador pouco antes, abandonou seu cargo no ministério da Agricultura em maio. ${ }^{700}$ Poucos meses depois, o político paulista lançou um documento declarando que libertaria todos os seus escravos no final de 1889 , prazo estipulado para a abolição proposta por Dantas. ${ }^{701}$ Em 13 de setembro, ensaiou romper por completo com o governo, advertindo-o que "teria de considerar eventualmente uma nova reforma da escravatura ou, então, perderia seu apoio", ${ }^{702}$

\footnotetext{
696 Ibid., p. 22.
}

697 Para o violento processo de colapso da escravidão em São Paulo, ver: Maria Helena Machado, op. cit. 698 Para o declínio da escravidão no Rio de Janeiro e nas províncias vizinhas, ver: Hebe Maria Mattos, op. cit. Ver também a obra de Lana Lage da Gama Lima, Rebeldia negra e abolicionismo. Rio de Janeiro: Achiamé, 1981, cap. 3 "Abolicionismo: Os Novos Horizontes", sobre a violência da segunda metade da década de 1880 em Campos, município com uma das maiores concentrações de mão de obra escrava do país.

699 Cf. Robert Conrad, op. cit., pp. 301-303.

700 Cf. Barão de Javari, op. cit., p. 221. Prado foi substituído por outro político paulista, Rodrigo Silva. 701 AS. 03/06/1887, pp. 14-18.

702 Cf. Robert Conrad, op. cit., p. 303. É importante destacar, também, que São Paulo já experimentava desde 1886 uma significativa corrente imigratória para a província, o que possibilitou que os fazendeiros 
Mais do que o início da "conversão" do Partido Conservador de São Paulo ao emancipacionismo, a deserção de Antônio Prado significou a completa derrota moral da lei de 1885, pelo reconhecimento de sua ineficácia por parte de seu coautor e executor. Prado, que com suas emendas e regulamentos havia sido peça-chave na formulação e aplicação da lei, dois anos depois de sua promulgação deixava evidente que a expressão "emancipação gradual do elemento servil" não tinha mais lastro na realidade objetiva do país, tornando-se politicamente inerme. ${ }^{703}$

Foi assim que, dias depois, João Alfredo Correia de Oliveira rompeu o silêncio na câmara vitalícia e declarou que um projeto de abolição da escravidão poderia ter seu apoio, "especialmente se fosse a última palavra sobre o assunto". 704 Ainda em setembro, outro senador conservador, o paulista Floriano de Godói, apresentou um projeto de extinção imediata da escravidão com prestação de serviços por três anos, além de disposições concernentes à repressão da ociosidade..$^{705}$

Declarações de Rodrigo Silva, ministro da Agricultura, a seu comprovinciano, Francisco de Paula Rodrigues Alves, presidente de São Paulo, demonstram bem a angustiosa posição do governo. Em uma carta datada do início de 1888, o ministro paulista asseverava que as notícias vindas da província produziam "ultimamente a mais profunda modificação no plano futuro do gabinete". ${ }^{706}$ Rodrigo Silva demonstrava incômodo em ter sido sua lealdade a São Paulo posta em dúvida por "diários artigos dos jornais da oposição", com o que muitos de seus correligionários na província não pareciam se importar. Defendendo a "lealdade obediente e disciplina partidária", devidas ao "chefe", referindo-se a Antônio Prado, o ministro afirmava não ter feito "uma única nomeação que não fosse indicada daí", sacrificando-se "para salvar a unidade do partido". Não obstante, as contrapartidas haviam sido seguidamente aviltantes para sua posição. No lugar de se esforçarem para a conservação do "atual ministério", muitos de seus comprovincianos pareciam trabalhar para "transformá-lo em barco que só pode navegar a reboque" e as consequências poderiam ser desastrosas:

adotassem uma postura menos defensiva quanto à emancipação.

703 As expectativas quanto ao prolongamento do cativeiro se mostraram ainda mais irrealizáveis quando o Exército passou a se recusar a perseguir e apreender escravos fugidos. Ibid., 306.

704 Ibid., p. 304. O autor cita o comentário irônico de um jornal do Rio Grande do Sul sobre as rápidas mudanças no posicionamento desses políticos conservadores: "qualquer dia veremos o Sr. Andrade Figueira fazer conferência no Polytheama, ao lado dos Srs. José do Patrocínio, Rui Barbosa e Joaquim Nabuco".

705 Ibid., p. 304.

706 Rodrigo Augusto da Silva a Francisco de Paula Rodrigues Alves, 03/02/1888. AIHGB. Col. Rodrigues Alves, DL 809.52. 
Por esta carta verá V. Como pensamos hoje; e não esperar tranquilo o próximo futuro. Eu devia dar-lhe aviso com tempo suficiente de preparar-se para qual quer [sic] eventualidade. Não é a sorte de um ministério que está em risco - é a situação. Nós não aceitamos nem aceitaremos jamais o programa da imediata emancipação. A transação hoje em dia seria [...] como recurso extremo de vida por que nos foi imposta como ultimatum. Além de que já a anarquia caminhou bastante. [...]

Quando aí estive, em conferência com o Prado, pareceu-me ainda tempo de evitar o perigo. Aqui chegando atuei no sentido de suas manifestações.

Tive esperanças. Vieram, porém, novos discursos, programas adiantadíssimos, censuras intempestivas, e tudo quanto parecia-me possível tornou-se impraticável.

V. é a única pessoa a quem comunico tudo isto. Temos guardado profunda reserva. Seria uma calamidade se soubessem com antecedência como pensamos presentemente. $^{707}$

Frente ao acelerado processo de colapso da escravidão e à radicalização das forças políticas, o projeto conservador de transição gradual ao novo regime de trabalho e reorganização paulatina do Estado ruía a olhos vistos. Não existindo já a "completa unidade do partido", 708 a resistência se tornava cada dia mais supérflua.

Diante desse contexto, Cotegipe iniciou a formulação de um projeto de abolição imediata em cujas linhas se enxergava a tentativa de preservar o que fosse possível do status quo. O projeto, que o senador baiano jamais teve chance de apresentar ao Parlamento, objetivava, segundo seu autor, resolver "o problema do elemento servil sem prejuízo do interesse particular, geral, moral e social". ${ }^{709}$ Seu preâmbulo listava as seguintes intenções:

Abolir a escravidão no Brasil já não é questão que se discuta; é ponto vencido e começado a executar pela Lei de 28 de Setembro de 1871.

O que está em discussão para todos os espíritos que desejam o complemento da obra sem abalos e sem ofensa de direitos é o modo prático de realizar esse complemento.

Neste estado da opinião, divergente no resultado dos estudos vários, a que se tem dedicado os homens aptos e competentes, formulei no estudo que ora ofereço á correção de todos, a enunciação de minhas ideias coordenadas em forma de projeto de lei, com o complexo das quais julgo atender ao mesmo tempo e como em um todo harmônico:

$1^{\circ}$ Aspiração unanime e sagrada do complemento da emancipação sem a espera mais ou menos longa de um prazo, sem um equivalente ou fator de redução que o torne nominal.

707 Ibid.

708 Ibid.

709 Resolução do problema do elemento servil sem prejuízo do interesse particular, geral, moral e social, oferecido ao governo na pessoa do eminente estadista Exmo. Sr. Barão de Cotegipe, Corte, 17/02/1888. AIHGB. Col. Cotegipe, L. 960 P. 30. 
$2^{\circ}$ Ao respeito devido ao direito de propriedade e a sua consequente indenização em toda a sua plenitude, sem os perniciosos abusos do fundo de emancipação e dos injustos arbitramentos judiciais.

$3^{\circ}$ Ao menor ônus possível, ônus nulo mesmo do tesouro publico, com garantir essa indenização [sic], cujo fim principal é proporcionar metodicamente à agricultura e à indústria os meios e capitais de que carecem, para poder dispensar e substituir o braço escravo, sem prejuízo dos seus credores hipotecários e pignoratícios [sic] por desmantelamento geral e instantâneo da propriedade servil.

$4^{\text {o }}$ Finalmente, à simplicidade, ordem e tranquilidade, brevidade sem sofreguidão, pausa sem delonga excessiva no plano e período do movimento e operação da emancipação e indenização paralelas, satisfazendo-se ao mesmo tempo os votos do abolicionista sensato, as exigências do senhor de escravos razoável e os reclamos instantes do interesse da nação. ${ }^{710}$

Em seus 41 artigos, que Cotegipe declarava estarem abertos para serem desenvolvidos e emendados, transparecia um projeto para o país marcadamente excludente e hierarquizado.

Nos primeiros artigos, ficava prevista a abolição imediata da escravidão, passando os cativos à condição de "servos". Aos senhores seriam dadas apólices, uma por servo, no valor nominal de 500 mil-réis, sendo que tal valor decresceria na ordem de $20 \%$ ao ano, ao mesmo tempo em que se acumulariam juros, garantidos pelo Estado, também na ordem de $20 \%$ ao ano. ${ }^{711}$ Deste modo, os senhores teriam direito à indenização por prestação de serviços durante cinco anos e, findo este período, recolheriam uma indenização pecuniária no valor de 500 mil-réis para cada apólice. ${ }^{712}$ Após o período de prestação de serviços e o resgate do valor da apólice pelo senhor, o servo teria direito a retirar seu título de "liberto", considerando-se assim emancipado.

Entre as disposições do capítulo intitulado Do trabalho, estava a obrigatoriedade do liberto em contrair ocupação. No art. 24, determinava-se que "o liberto que não exercer profissão ou emprego, ou não tiver de sua propriedade lavoura ou indústria por onde granjeie a subsistência, fica sujeito a imediata inspeção da polícia”, que o constrangeria a empregar-se no ramo de atividade em que houvesse vaga disponível. O liberto que passasse por inspeção policial teria seu domicílio fixado no município em que se

\section{Ibid.}

$711 \mathrm{O}$ senhor poderia transferir a apólice a que estava vinculado o servo, o que significava que este a acompanharia para seu novo proprietário. Isto ficava claro no art. $9^{\circ}$ : "Nenhuma transferência ou transação poderá ter por objeto o servo e sim a apólice que lhe é relativa e a qual o servo acompanha no domínio e posse do respectivo proprietário". Cada transação implicaria numa desvalorização da apólice também na ordem de $20 \%$. Ibid.

712 As anuidades e transferências não eram excludentes entre si, ou seja, se, por exemplo a apólice fosse transferida por duas vezes em três anos, o servo estaria emancipado. Ibid. 
encontrasse, até que recebesse "da polícia atestado de boa e exemplar conduta". 713

Dentre as inúmeras disposições do projeto, as acima elencadas oferecem um bom panorama de seu conteúdo geral. Eram suas prioridades a garantia da ordem, bem como o reconhecimento da legalidade da propriedade escrava e da legitimidade da autoridade senhorial, expresso na indenização por duas vias, por prestação de serviços e pecuniária. Reconhecendo plenamente a validade das leis emancipacionistas anteriores e prolongando a existência de uma categoria jurídica específica herdada da escravidão, bem como criando uma nova, garantia-se que os "servos" e, depois, "libertos" jamais atingiriam a cidadania plena, sendo mantidos vitaliciamente sob restrições bastante consideráveis e sob uma dupla tutela: de seus ex-proprietários e do Estado.

Menos do que uma ruptura com o escravismo, o projeto de Cotegipe encetava a perpetuação de relações sociais e jurídicas, bem como de severas restrições aos direitos de cidadania, herdadas do cativeiro, doravante sobre outros alicerces. Não era um projeto de ampliação de direitos políticos, como fora a lei eleitoral de 1881, nem um projeto de integração rápida da população libertada no corpo político e social do país, como foram os projetos apresentados por Dantas ou Afonso Celso Jr. Era a recuperação de uma lógica de emancipação gradual baseada na perpetuação de elementos basilares do escravismo em uma sociedade já emancipada, conjugando-se autoridade senhorial, tutela do Estado e hierarquização social no pós-emancipação. Diante da derrota do projeto de superação lenta do escravismo, Cotegipe tentaria reavivá-lo numa realidade posterior à sua extinção.

É provável que o presidente do Conselho esperasse a abertura das câmaras para apresentar seu projeto ou, ao menos, uma versão de seu texto. Contudo, os acontecimentos se sucederam rapidamente e poucas semanas depois o senador baiano deixava a chefia do governo.

Nos primeiros dias de março de 1888, uma série de distúrbios ocorreram na Corte, transformando regiões da capital do Império em verdadeiras praças de guerra. Tudo começou após a prisão de um oficial da Marinha pela polícia, sob acusação de causar tumultos nas ruas do Rio de Janeiro. A prisão do capitão Antônio José Leite Lobo gerou revolta entre praças da Armada, que haviam, pouco antes, recebido permissão para desembarcar dos navios em que se encontravam. Estes, então, iniciaram uma série de ataques contra as forças policiais, sendo acompanhados por "imperiais, paisanos, capoeiras 
e outros desordeiros". 714

Respondendo ao relato do ministro da Justiça, a princesa Isabel, que no ano anterior assumira a regência do Império ${ }^{715}$ e que já expressara preocupação quanto às divisões do Partido Conservador no que concernia à questão servil, ${ }^{716}$ incentivando Cotegipe a apresentar alguma solução ao problema, destacou a responsabilidade ministerial sobre as ações da força pública e sugeriu a demissão do Chefe de Polícia da Corte, declarando que o gabinete perdia "força moral". Diante das manifestações da regente, colocadas claramente no terreno da confiança política, a vulnerabilidade do gabinete cresceu ainda mais.

Alguns dias depois, em conferência privada com a princesa, Cotegipe tentou dissuadila de persistir na incompatibilidade com o governo, afirmando que seria mais seguro aguardar a reabertura das câmaras para que a situação política do ministério fosse conhecida. Contudo, ciente das condições precárias em que se encontrava o presidente do Conselho, especialmente após as derrotas eleitorais de fins de $1887^{717}$ e as declarações dos chefes conservadores de São Paulo e Pernambuco, Isabel mostrou-se irredutível. Diante disto, Cotegipe apresentou a demissão do ministério e se recusou a indicar um nome para a sucessão. A par do programa de emancipação imediata que Antônio Prado sustentava em São Paulo, a regente indicou o nome de João Alfredo, mais comedido em suas declarações.

Segundo relato de Isabel a seus pais:

Quanto ao Ministério terão sabido pelos jornais o que houve. Os últimos tumultos muito me entristeceram. Há tempos minhas ideias divergiam das do Ministério, sentia que o Governo perdia muita força moral, já alguma coisa neste sentido dissera há bastante [sic] semanas; agora com mais firmeza e por escrito, censurando ao mesmo tempo a polícia e em grande parte o que houve; a polícia ou antes as atitudes tomadas pelas autoridades policiais há já algum tempo. Minha declaração da perda de força moral, e de que insistia pela demissão do Chefe de Polícia deu em resultado a queda do Ministério. Não me arrependo do que fiz. Mais tarde ou mais cedo o teria feito; confesso que uma surda irritação se apossara de mim e em consciência não devia continuar com um Ministério, quando eu, por mim mesma, sentia que ele não preenchia as aspirações do país nas circunstâncias atuais. Deus me

714 As informações se baseiam nos relatos do ministro da Justiça, Samuel Wallace Mac-Dowell, em correspondência com a princesa regente. AIHGB. Col. Barão de Cotegipe, DL 960.31.

715 O Imperador partira para a Europa em meados do ano anterior, visando a tratar de uma grave enfermidade. Cf. Roderick J. Barman, op. cit., pp. 471-472.

716 Em conferência com o chefe do governo no mês de janeiro de 1888, Isabel já expressara sua preocupação com a situação em São Paulo, afirmando considerar necessário um posicionamento claro do governo no sentido de responder ao novo estado de coisas. A conferência é mencionada por Cotegipe e pela princesa, em notas. Respectivamente: AIHGB. Col. Cotegipe, DL 960.28; Id., DL 960.32, doc. 1. Cópia.

717 Entre outras, foi significativa a derrota do recém-nomeado ministro do Império, Manuel do Nascimento Machado Portela, para Joaquim Nabuco, no $1^{\circ}$ distrito de Pernambuco, no $2^{\circ}$ semestre de 1887 . Cf. Barão de Javari, op. cit., p. 399. 
ajude e que a questão da emancipação dê breve o último passo que tanto desejo ver chegar! Há muito a fazer, mas isso antes de tudo. ${ }^{718}$

Diante do clima político do país, as alternativas a Cotegipe que se apresentavam à regente não eram, de fato, muitas. Por um lado, não era possível a um "emperrado", como Paulino de Souza, assumir a presidência do Conselho. Por outro, a ascensão dos liberais não só poderia significar uma solução radical da questão, como também implicaria na realização de novas eleições, a serem conduzidas num contexto de extremismo político. Sobravam os dois líderes emancipacionistas do Partido Conservador. Antônio Prado já se havia comprometido, em sua província, com a emancipação imediata. Lá, onde o colapso da escravidão já era um dado de realidade, a abolição condicional não fazia mais sentido. Deste modo, João Alfredo era o único que poderia se comprometer com uma lei de emancipação que não alienasse as regiões que ainda dependiam do trabalho escravo, em especial a Zona da Mata mineira, o Recôncavo baiano e a província do Rio de Janeiro, bem como algumas outras áreas do Norte do país, ${ }^{719}$ e que, simultaneamente, pudesse atender aos anseios dos mais "adiantados". Deste modo, ao ascender à presidência do Conselho, ao senador pernambucano foi delegada a ingrata tarefa de compor com as forças políticas em rota de colisão, até mesmo dentro de seu próprio partido.

Rodrigo Silva foi o responsável por encetar a tentativa de alinhavar um acordo com o mais intransigente de seus correligionários. Na sua casa, às vésperas da organização do novo gabinete, reuniu-se com Paulino de Souza. Segundo relato do senador fluminense, ${ }^{720}$ Prado se recusara a assumir o ministério por julgar "ser conveniente dar à questão servil solução muito mais prudente e moderada do que aquela a que obrigaria a coerência" com as ideias por ele manifestadas em São Paulo. Os conservadores da província haviam aprovado, então, a permanência de Rodrigo Silva na pasta da Agricultura, não obstante a transição ministerial, e insistiram nesse ponto. Aprovando a recusa de Antônio Prado, dado que seu plano emancipador se assentava "na burla das leis que coagem o trabalhador servil a estar na companhia do senhor e prestar-lhe serviços", Paulino destacou ser necessário

\footnotetext{
718 Apud Manuel Correia de Andrade, João Alfredo: o estadista da abolição. Recife: FUNDAJ, Editora Massangana, 1988, p. 174. Mais adiante, Isabel complementou: "Quanto à escolha dos novos ministros fui eu quem indicou o João Alfredo. Este foi quem escolheu os outros. Deixei-lhe toda a liberdade para que pudesse organizar o gabinete como fosse necessário, à vista da maioria parlamentar". A carta é datada de 14 de março de 1888.

719 Cf. Hebe Maria Mattos, op. cit., B. J. Barickman, op. cit.

720 Notas do Conselheiro Paulino José Soares de Sousa sobre a organização do ministério 10 de março de 1888. AIHGB. Arquivo Wanderley Pinho, DL 1593.02 (cópia).
} 
esperar pela opinião do barão de Cotegipe para "verificar se havia a resolução de compromisso em fazer executar fielmente a lei de 1885 até votar-se lei nova e de executar também esta quando decretada". O senador fluminense concordou, nesse sentido, com "a entrada do Conselheiro Rodrigo no novo gabinete mediante as cláusulas propostas, porque ele significaria que a política do [ministério] 20 de Agosto projetava-se sobre no novo como seguimento e solidariedade da situação conservadora". ${ }^{721}$

No entanto, ao receber notícias de uma reunião entre Prado e João Alfredo, Paulino percebeu que suas esperanças por um último compromisso de sustentação do trabalho escravo, por ainda algum tempo, eram baldadas:

No dia 10 de Março, pouco antes do meio-dia, o Conselheiro Rodrigo Silva aparecendo em minha casa comunicou-me que da conferência de Prado com J. Alfredo resultara ter aquele de entrar no novo gabinete com o programa da abolição imediata e serviço dos libertos por três anos, exigindo Prado que ele, Rodrigo Silva, também com ele fosse ministro. Encheu-me de pasmo essa notícia $1^{\circ}$ porque a intenção revelada por Prado de não ser agora ministro para não precipitar a solução da questão servil era, sem dúvida, sensata e prudente, na conveniência de não se desorganizar o trabalho rural em outras províncias ainda não preparadas, como a de S. Paulo, para a difícil transição, que preocupa todos os homens conhecedores da nossa lavoura, $2^{\circ}$ porque a passagem de Rodrigo do gabinete Cotegipe, cujo programa era a resistência, para o novo gabinete, que se propunha a realizar a abolição imediata, era um salto mortal sobre um abismo impossível de transpor. ${ }^{722}$

Em reunião na casa de Cotegipe, Prado afirmou a Paulino ter ficado impedido de recusar a nomeação ministerial após João Alfredo garantir-lhe o plano de abolição imediata com prestação de serviços e declarar que não organizaria gabinete sem sua presença. ${ }^{723}$ Nesse caso, a alternativa seria a ascensão do Partido Liberal, com a qual "nada lucraria a lavoura” e sofreriam “os nossos amigos políticos, privados do poder". Paulino, pouco convencido, redarguiu "que se era para fazer-se a abolição imediata que se organizava o novo ministério, sem dúvida que ao partido liberal cabia o poder, estando na sua índole realizar reformas radicais"; declarando, então, que permaneceria "no plano da lei vigente", o senador fluminense asseverou que sua posição quando se abrisse o

721 Ibid. Contudo, Paulino não deixou "de achar um que de singular e incongruente na intenção" que se lhe confiava.

722 Ibid. Em fevereiro, quando já ficava clara a insustentabilidade do gabinete Cotegipe, diversos deputados conservadores se reuniram com João Alfredo para perscrutar seus planos com relação à emancipação, caso fosse chamado a organizar gabinete. O plano, aceito então por Paulino, previa a continuação da escravidão por mais cinco anos e o "aprendizado" por mais três, com fixação obrigatória do liberto nas fazendas para prestação de serviços. Tendo em vista que poucas semanas depois já se falava de abolição imediata, compreende-se a estupefação de Paulino. Cf. Tobias Monteiro, op. cit., p. 91, n. 10.

723 Prado assumiria a pasta dos Negócios Estrangeiros. Cf. Barão de Javari, op. cit., p. 232. 
Parlamento, em maio, dependeria do procedimento do ministério. ${ }^{724}$

Antônio Prado tentou, ainda, uma solução de compromisso. De sua província natal, enviou a João Alfredo um projeto que promovia a abolição, bem como uma série de medidas que objetivavam garantir a organização do trabalho e a disciplinarização dos exescravos. ${ }^{725} \mathrm{O}$ art. $1^{\circ}$ dispunha acerca da extinção imediata da escravidão com prestação de serviços até o dia de Natal daquele ano, recebendo em troca módicos pagamentos. Após esse período, previa-se a fixação obrigatória dos "libertos" nos municípios em que estivessem matriculados, impondo-se que se ocupassem, sob pena de prisão em caso de ociosidade. ${ }^{726}$ Talvez uma das passagens mais simbólicas do projeta fosse a última do art. $2^{\circ}$. Vale a pena reproduzi-la:

$\S 12^{\circ}$ Haverá em cada município uma junta, composta do presidente da câmara municipal e dos dois proprietários agrícolas do município que maior número de escravos possuírem na data da promulgação desta lei, incumbindo à junta de velar na sua boa execução, auxiliar o poder público nas medidas de ordem e segurança que tenha de ser postas em prática, requisitar das autoridades aquelas que julgarem convenientes e oportunas a bem da regularidade do trabalho agrícola e representar as [sic] autoridades superiores contra os abusos que se cometerem na execução da presente lei. ${ }^{727}$

No entanto, a inaplicabilidade de restrições aos futuros libertados se mostrava a cada dia uma realidade. A própria queda do gabinete Cotegipe parece ter sido encarada como a derrota fatal da escravidão e de qualquer possibilidade de prolongá-la por outros meios. Simbólicos da inflexão gerada pelo fracasso da política do ministério de 20 de agosto são os relatos do conselheiro Tomás José Coelho de Almeida, conservador ligado à região do município de Campos, no norte do Rio de Janeiro, a Paulino de Souza. Lá, onde os conflitos entre fazendeiros, escravos insurgentes e abolicionistas haviam alcançado níveis extremos, a retirada de Cotegipe causara "péssima impressão". A invasão de um jornal abolicionista, onde se encontravam acoitados dezenas de escravos, combinada "com a autoridade policial e o comandante do destacamento policial para a noite de 7 para 8 de

724 Notas do Conselheiro Paulino José Soares de Sousa sobre a organização do ministério 10 de março de 1888. AIHGB. Arquivo Wanderley Pinho, DL 1593.02 (cópia).

725 Prado convalescia de uma grave enfermidade e o projeto foi enviado por meio de seu cunhado, Elias Chaves. CHAVES, Elias Antônio Pacheco. Carta ao conselheiro João Alfredo Corrêa d'Oliveira, enviando o projeto de lei abolindo a escravidão no Brasil. São Paulo, 20/04/1888. 2 doc. (7p.). Biblioteca Nacional. Arquivo Tobias Monteiro. 64,02,002, $\mathrm{n}^{\circ} 014$.

726 Os libertos só poderiam deixar os municípios com licença dada pelo juiz de órfãos, no caso de provarem não conseguir ocupação ou com autorização de seus "locatários". Ibid. 727 Ibid. 
março" foi frustrada pela chegada da notícia da "queda do 20 de Agosto". Dela resultara "tal quebra da força moral que, segundo telegrama recebido dali", dias depois já se achavam "acoitados em Campos cerca de mil escravos fugidos". 728

Em maio, na recepção do ministério João Alfredo pelo Parlamento, senadores liberais deixaram claro que não aceitariam libertação condicional. Silveira Martins criticou leis de repressão à "vadiagem" que tivessem como alvos os libertos, pelo fato de que a Constituição lhes garantia cidadania. ${ }^{729}$ Afonso Celso, por sua vez, declarou que a abolição não teria grandes dificuldades em passar pelo Parlamento, mas criticou o trecho da Fala do Trono que afirmava ser necessário organizar o trabalho antes de extinguir a escravidão, ${ }^{730}$ opondo-se a possíveis restrições aos libertados pela lei:

Estas questões preocupam o orador, e cumpre-lhe declarar ao nobre presidente do Conselho que não deve contar com o apoio dos representantes liberais se seu projeto não proclamar a liberdade imediata e incondicional. (Apoiados da bancada liberal.)

Quaisquer restrições, qualquer limitação encontrarão a mais viva e decidida resistência. O liberto deve entrar para o regime comum. (Apoiados da bancada liberal. $)^{731}$

Diante da perspectiva de enfrentar a oposição liberal, sem poder contar com o apoio decisivo de Paulino de Souza e ante as condições objetivas do país, o governo não teve opções senão apresentar um projeto de lei tão sucinto quanto definitivo:

Art. $1^{\circ}$ É declarada extinta, desde a data desta Lei, a escravidão no Brasil.

Art. $2^{\circ}$ Revogam-se as disposições em contrário. ${ }^{732}$

A Lei Áurea, assinada pelo ministro da Agricultura, Rodrigo Silva, que três meses

728 Notas do Conselheiro Paulino José Soares de Sousa sobre a organização do ministério 10 de março de 1888. AIHGB. Arquivo Wanderley Pinho, DL 1593.02 (cópia). Sobre o jornal Vinte e Cinco de Março, célebre por seu abolicionismo radical, ver: Tanize do Couto Costa Monnerat, Abolicionismo em ação: $o$ jornal Vinte e Cinco de Março em Campos dos Goytacazes (1884-1888). Dissertação de Mestrado em História Social, Rio de Janeiro: Unirio, 2013. O nome do jornal fazia referência à libertação do Ceará, ocorrida em 25 de março de 1884.

729 AS. 07/05/1888, p. 21.

$730 \mathrm{Na}$ Fala do Trono de 1888, lia-se: "Mediante providências que acautelem a ordem na transformação do trabalho, apressem pela imigração o povoamento do país, facilitem as comunicações, utilizem terras devolutas, desenvolvam o crédito agrícola e aviventem a indústria nacional, pode-se asseverar que produção sempre crescente tomará forte impulso e nos habilitará a chegar mais rapidamente aos nossos auspiciosos destinos". ACD. Sessão de 1888, tomo I, p. 4.

731 AS. 07/05/1888, p. 22.

732 ACD. Sessão de 1888, tomo I, p. 25. 
antes asseverara que não aceitaria "jamais" o plano da abolição imediata, ${ }^{733}$ foi promulgada apenas cinco dias depois de apresentada à Câmara dos Deputados. ${ }^{734}$

Após o ato, qualquer unidade possível entre os conservadores ruiu por completo. Do Senado, Paulino de Souza e Cotegipe lançavam ataques severos ao governo, defendendo indenização. ${ }^{735} \mathrm{O}$ gabinete tentava conciliar interesses, oferecendo inúmeras concessões à lavoura, por meio de projetos de repressão à ociosidade e de ampla concessão de crédito agrícola. ${ }^{736}$ Nada foi capaz de salvar o gabinete do contínuo processo de desgaste e, em fins de 1888, a "esterilidade" de sua política era evidente. ${ }^{737}$

Quando da reabertura do legislativo em 1889, o ministério viu-se sem número para fazer quórum nas sessões parlamentares. Mais de 50 deputados, entre eles pelo menos 28 liberais e 22 conservadores, faziam-lhe oposição. ${ }^{738}$ Diante de tal quadro, João Alfredo solicitou a dissolução da Câmara dos Deputados ao monarca. Na sessão do Conselho de Estado convocada para discutir tal solicitação, Paulino de Souza não poupou o gabinete, que considerava haver "traído" as perspectivas de seus correligionários:

No estado atual do espírito público o que aconselham a prudência e o bom senso é o emprego de medidas tendentes a apaziguar a agitação, que por todos os modos se manifesta contra a política do gabinete e não a provocação de novas reações por ato de tanto alcance, como a dissolução da Câmara dos Deputados, para dar razão contra as censuras parlamentares infligidas a um gabinete que, pode-se dizer sem rebuço, incorreu no descrédito e animadversão pública.

$\mathrm{O}$ apelo feito pela Coroa para um pronunciamento da nação entre o Ministério por ela conservado e a câmara, que dissolve, importa sem dúvida a antecipação de um juízo favorável àquele na divergência ocasionada: deve assentar na convicção bem formulada de ter o Ministério por si na opinião pública elementos capazes de sustentálo vigorosamente contra as forças políticas, que se moveram para tirar-lhe a confiança dos mais imediatos representantes da nação e que, se deve esperar, intervirão com muito maior energia na luta eleitoral, que se travar por efeito da dissolução.

$[\ldots]$

É certo que o gabinete ainda tem maioria de votos conservadores na Câmara dos Deputados; não menos incontestável é, porém, estar nas mãos da oposição levantada no seio do próprio lado, de que ele saiu, a bandeira do partido [Conservador], cuja

733 Rodrigo Silva a Rodrigues Alves, 03/02/1888. AIHGB. Col. Rodrigues Alves, DL 809.52.

734 Entre os presentes quando da votação da lei na câmara temporária, apenas nove deputados conservadores negaram-lhe seu voto, oito representantes do Rio de Janeiro e um de Pernambuco. ACD. Sessão de 1888, tomo I, p. 35.

735 AS. Sessão de 1888.

736 ACD. Sessão de 1888.

737 Antônio de Siqueira a Luís Filipe de Sousa Leão, 19/08/1888. AIHGB. Col. Sousa Leão, DL 456.160.

738 Dos conservadores, oito oposicionistas representavam a província do Rio de Janeiro. Os outros provinham de Pará, Piauí, Ceará, Pernambuco, Maranhão, Minas Gerais e Rio Grande do Sul. As três últimas tinham mais de um dissidente em suas bancadas: três, dois e dois, respectivamente. Diário de Notícias. 06/05/1889, p. 1. O posicionamento de alguns deputados não foi computado por estarem ausentes nas primeiras sessões parlamentares. 
índole repele os atos praticados com violação da fé política e tradições do mesmo partido, assim como dos compromissos anteriores dos seus autores. A posição falsa, em que se vê o gabinete perante o seu próprio partido, aliena-lhe nesta todas as adesões que não se lhe prendem por interesses administrativos ou por motivos particulares de ordem análoga e não o habilita senão com o elemento da fraqueza para a luta, a que irrefletidamente se dispõe, solicitando para nela legitimar-se da intervenção do Poder Moderador, que afinal exporá a alguma nova contingência depois de irrefletidamente ter exposto a realeza, que ele não tem corpo para resguardar da animadversão das classes conservadoras, feridas desastradamente em interesses que a prudência devia levá-lo a acautelar por alguma forma. ${ }^{739}$

Após as manifestações dos outros conselheiros, cuja maioria, entre liberais e conservadores, se colocou contrariamente à dissolução, o Imperador aceitou a demissão de João Alfredo. Procurando-se recompor a situação conservadora, dada a ampla maioria de que gozava o partido na Câmara, tentou-se delegar a organização ministerial a três destacados nomes do partido. Manuel Francisco Correia e Jerônimo José Teixeira Júnior, já visconde de Cruzeiro, se recusaram a atender o chamado da Coroa. O visconde de Vieira da Silva, conservador pelo Maranhão, tentou constituir gabinete, mas fracassou diante das irreconciliáveis diferenças entre "paulinistas" e "alfredistas". ${ }^{740}$ A solução, então, foi apelar ao Partido Liberal.

Após as renhidas lutas políticas de meados da década, o Partido Conservador teve de aceitar a perspectiva de que a Lei do Ventre Livre deixaria de ser a palavra final no processo de emancipação no país, com o estabelecimento de um prazo final para o cativeiro. A partir de então, as forças conservadoras se esforçaram em garantir que tal prazo fosse o mais distante possível, deixando tempo para uma transição gradual e dentro da ordem, pautada por princípios que tinham, como seus alicerces, o reconhecimento, mesmo que póstumo, da legalidade da propriedade servil, da legitimidade do cativeiro e da tutela daqueles que viriam a ser libertados. Tal projeto de país, pautado pela lentidão da integração dessas parcelas à sociedade e pela limitação de direitos políticos, era profundamente hierárquico, não reconhecendo na plena igualdade civil ou política um mote para o pós-emancipação. Quando ficou clara, dada a conflagrada realidade social e política do país, a inaplicabilidade de tal projeto, uma parcela do partido consentiu na distensão da resistência, dividindo-o irreversivelmente. O pós-abolição foi marcado pelo fracasso conservador na formulação de um novo projeto para o país em que o

739 Atas do Conselho de Estado Pleno. Terceiro Conselho de Estado. 31/05/1889.

740 Cf. Sérgio Eduardo Ferraz, op. cit., pp. 204-205. O principal chefe conservador, barão de Cotegipe, que se colocara em oposição a João Alfredo, falecera em fevereiro de 1889. 
prolongamento do escravismo, e das relações sociais por ele pautadas, não fosse mais o alicerce fundamental.

\section{3 - Projetos de (re)organização do Estado}

Alguns dias após a promulgação da Lei Áurea, um jornal liberal da Corte publicou um editorial expondo as dúvidas e incertezas que se assomavam no país diante do lacônico ato legislativo. Sem programas claramente definidos para lidar com uma realidade imposta pela intensa conflagração social e política que marcava a década de 1880, e cujo clímax fora a libertação incondicional de todos os escravos do Império, solução impensável alguns anos antes, os partidos monárquicos precisavam, sugeria o articulista, se arregimentar com a maior brevidade possível. Só assim poderiam dar respostas aos anseios e dúvidas que assoberbavam a nação:

Essa multidão, que anteontem saiu do regime servil e rompeu com ele - de que modo viverá, a que ramo de trabalho consagrará a sua atividade?

$\mathrm{Na}$ hipótese provável de querer abandonar as fazendas ou as casas dos exsenhores, virão para os centros de população - a corte, as cidades - figurarem como novos e avultados elementos de perturbação?

A cargo de quem ficarão os velhos, os menores ingênuos, os que necessitam de socorro e amparo?

É lícito aos ex-senhores manterem a posse dos ingênuos em virtude da lei de 28 de setembro [de 1871], contra a de 13 de maio?

Subsistem as obrigações, contraídas sob o regime servil, à vista da liberdade plena e incondicional da lei de 13 de maio de 1888 ?

Serão localizados os libertos?

Mas se entram na massa da população, e se de conformidade com o $\S 1^{\circ}$ do art. $6^{741}$ da Constituição Política são cidadãos, indisputavelmente adquiriram o direito de transitar por onde lhes aprouver, de escolher domicílio, gênero de indústria e trabalho, que lhes convenha - $\S \S 6,13,14$ e 24 do art. $179 .^{742}$

Uma lei de localização importará uma violação da Constituição, e um atentado

$741 \mathrm{O}$ art. 6 da Constituição de 1824 definia quem eram os cidadãos brasileiros; de acordo com o primeiro parágrafo: "Os que no Brasil tiverem nascido, quer sejam ingênuos, ou libertos, ainda que o pai seja estrangeiro, uma vez que este não resida por serviço de sua Nação”. Cf. Adriano Campanhole; Hilton Lobo Campanhole, op. cit.

$742 \mathrm{O}$ art. 179 dispunha: “A inviolabilidade dos Direitos Civis, e Políticos dos Cidadãos Brasileiros, que tem por base a liberdade, a segurança individual, e a propriedade, é garantida pela Constituição do Império, pela maneira seguinte", sendo que os parágrafos citados pelo articulista continham as seguintes especificações: $\$ 6^{\circ}$ Qualquer [cidadão] pode conservar-se, ou sair do Império, como lhe convenha, levando consigo os seus bens, guardados os Regulamentos policiais, e salvo o prejuízo de terceiro; $\$ 13$ A Lei será igual para todos, quer proteja, quer castigue, o recompensará em proporção dos merecimentos de cada um; $\$ 14$ Todo o cidadão pode ser admitido aos Cargos Públicos Civis, Políticos, ou Militares, sem outra diferença, que não seja dos seus talentos, e virtudes; \$24 Nenhum gênero de trabalho, de cultura, indústria, ou comércio pode ser proibido, uma vez que não se oponha aos costumes públicos, à segurança, e saúde dos Cidadãos. Ibid. 
contra a liberdade individual, que não pode ser coactada em sua mobilidade natural e social?

Uma lei de trabalho obrigatório será a instituição de nova escravidão sob uma forma diferente, porque exclui a responsabilidade, que assenta sobre a vontade de cada indivíduo, e tira-lhe a liberdade de ação - é precisamente o característico da escravidão.

$[\ldots]$

$\mathrm{O}$ acesso dos libertos à nova ordem social permite que continue o regime eleitoral, ou se lhe deve alargar a base até abranger estas novas classes sociais?

Será justo chamá-las ao benefício da civilização, e privá-las do direito de voto e da representação no governo do país?

Não terão os libertos, como cidadãos, direito a todas as funções públicas - mas se forem obrigados por lei a darem a sua atividade a ramo determinado de trabalho, não ficarão esbulhados daquele direito? Não ficarão sujeitos a um regime excepcional? ${ }^{743}$

As incertezas não eram apanágio dos que se encontravam fora do Parlamento. Pouco antes da assinatura da lei de abolição da escravidão pela princesa regente, quando já era um dado de realidade que seria imediata e incondicional, dois dos estadistas mais importantes do Segundo Reinado destoaram do êxtase generalizado que tomava conta da capital do Império. No Senado, Paulino de Souza e o barão de Cotegipe subiram à tribuna para reconhecer sua derrota como homens políticos e alertar os ouvintes para os perigos contidos naquele ato. Para o senador fluminense, o "confisco" da propriedade servil sem contrapartida e a libertação de centenas de milhares de escravizados “despreparados" para o exercício da liberdade era um ato ilegal, despótico e potencialmente desastroso:

A proposta que se vai votar é inconstitucional, antieconômica e desumana. É desumana, porque deixa expostos à miséria e à morte os inválidos, os enfermos, os velhos, os órfãos e crianças abandonadas da raça que quer proteger, até hoje nas fazendas a cargo dos proprietários, que, hoje arruinados e abandonados pelos trabalhadores válidos, não poderão manter aqueles infelizes, por maiores que sejam os impulsos de caridade, que é conhecida e admirada por todos os que frequentam o interior do país. É antieconômica, porque desorganiza o trabalho, dando aos operários uma condição nova, que exige novo regime agrícola; e isto, Sr. Presidente, ao começar-se uma grande colheita, que aliás poderia, quando feita, preencher apenas os desfalques das falhas dos anos anteriores. [...] É inconstitucional, porque ataca de frente, destrói e aniquila para sempre uma propriedade legal, garantida, como todo o direito de propriedade, pela lei fundamental do Império entre os direitos civis do cidadão brasileiro, que dela não pode ser privado, senão mediante prévia indenização do seu valor. ${ }^{744}$

743 Diário de Notícias. 16/05/1888, p. 1. O editorial também levantava interrogações sobre a situação das dívidas, taxas e multas vinculadas à propriedade servil, tema que dividiu os parlamentares. Os liberais, em sua maioria, parecem ter se oposto ao perdão de tais obrigações dos ex-proprietários, enquanto os conservadores ofereceram projeto para que houvesse uma anistia geral à "classe espoliada". AS. Sessão de 1888.

744 AS. 13/05/1888, p. 41. 
Cotegipe, na véspera, fora ainda além ao alertar para o precedente estabelecido pelo ato "irresponsável":

E de um traço de pena se legisla que não existe mais tal propriedade [escrava], que tudo quanto podia ter relação com ela desaparece, que nem contratos, nada absolutamente pode ter mais vigor. [...] Enfim, senhores, decretase que neste país não há propriedade, que tudo pode ser destruído por meio de uma lei, sem atenção nem a direitos adquiridos, nem a inconvenientes futuros. [...] Sabeis quais as consequências? Não é segredo: daqui a pouco se pedirá a divisão das terras, do que há exemplo em diversas nações, desses latifundia, seja de graça ou por preço mínimo, e o Estado poderá decretar a expropriação sem indenização. ${ }^{345}$

Para além das censuras e lamentações decorrentes da derrota sofrida, após tão obstinada resistência, os discursos dos senadores conservadores tinham o objetivo de expor as expectativas e preocupações de setores da sociedade imperial que assistiam consternadas ao surgimento de uma nova, e radicalizada, situação política no país. Suas palavras indicam o esforço em recolocar as perspectivas das "classes conservadoras" dentro do campo de disputas políticas. Em outros termos, aceitando a inevitabilidade da libertação imediata, iniciavam a luta para garantir o reconhecimento póstumo da legalidade e legitimidade da escravidão, visando não apenas à indenização dos "espoliados" pelo ato legislativo que se promulgaria em poucas horas, mas ao resgate, em outras formas, de uma agenda política que tinha na gradualidade e lentidão da transição sua prioridade, com a reiterada necessidade de reestabelecimento da ordem no campo e nas cidades, por meio do controle da população libertada em 13 de maio. Contudo, essa perspectiva de superação gradual do escravismo que, com importantes nuances, fora reiterada dentro de um compromisso suprapartidário que se sustentou até certo momento, deixara de fazer parte da realidade política do país. Isto ficou evidente em uma pequena, mas significativa, discussão ocorrida durante o discurso proferido por Cotegipe.

Em um momento em que o senador baiano declarou-se a favor da criação de “sociedades de proteção aos libertos", sendo estas necessárias para, em suas palavras, "darlhes ocupação e colocá-los”, a fala foi interrompida pelo liberal mineiro Cândido de Oliveira, que protestou: "Não há mais libertos; são cidadãos brasileiros". Provocando hilaridade na audiência, Cotegipe respondeu: "São libertos; mas direi, se quiser, até que 
são ingleses (risadas). Eu uso do termo próprio". ${ }^{746}$ Este pequeno trecho poderia passar por trivial, mas, pelo contrário, desvelava visões e expectativas diametralmente opostas para o país e estava intimamente conectado às interrogações avançadas pelo Diário de Notícias, expostas mais acima.

Ao condenar o uso do termo "liberto" para se referir aos escravos que dentro em pouco seriam libertados, Cândido de Oliveira atacava diretamente qualquer legitimidade que pudesse ainda ser atribuída à escravidão, defendendo, assim, a total ruptura com o passado escravista do país. O senador mineiro não apenas defendia, portanto, a incondicionalidade da abolição, mas também a extinção de qualquer condição jurídica específica que pudesse ser por ela legada ao país. Longe de uma cidadania limitada ou condicional, defendia a total integração do ex-escravo, fosse aquele libertado em 13 de maio, fosse aquele anteriormente emancipado, no "regime comum", como expressara outro senador liberal mineiro, Afonso Celso, poucos dias antes. ${ }^{747}$

A distinção torna-se ainda mais significativa quando se recuperam as perspectivas conservadoras para o pós-emancipação, no momento em que se mostrou evidente não ser mais possível adiar a libertação. O exemplo extremo provinha da pena do próprio barão de Cotegipe, que, como vimos, meses antes formulara um projeto, jamais apresentado a seus pares, no qual criava de forma explícita categorias jurídicas distintas, sujeitas a restrições e constrangimentos específicos por parte das autoridades. ${ }^{748} \mathrm{Em}$ outros projetos conservadores, a limitação à movimentação dos libertados, a criminalização da ociosidade, dentre outras propostas, demonstravam muito bem que a universalização da cidadania plena não estava em seus horizontes. ${ }^{749}$

Após a Lei Áurea, a atuação parlamentar de Cotegipe e Paulino se pautou pela defesa da indenização aos ex-proprietários de escravos, enquanto o governo de João Alfredo tentava avançar projetos de reorganização do trabalho e incremento do crédito agrícola disponível à lavoura. ${ }^{750}$ Contudo, a cizânia que tomou conta da situação conservadora, cuja

746 Ibid., p. 36.

747 AS. 07/05/1888, p. 22.

748 Resolução do problema do elemento servil sem prejuízo do interesse particular, geral, moral e social, oferecido ao governo na pessoa do eminente estadista Exmo. Sr. Barão de Cotegipe, Corte, 17/02/1888. AIHGB. Col. Cotegipe, L. 960 P. 30.

749 ACD. Sessões de 1887 e 1888; AS. Sessão de 1888; CHAVES, Elias Antônio Pacheco. Carta ao conselheiro João Alfredo Corrêa d'Oliveira, enviando o projeto de lei abolindo a escravidão no Brasil. São Paulo, 20/04/1888. 2 doc. (7p.). Biblioteca Nacional. Arquivo Tobias Monteiro. 64,02,002, no 014.

750 Em 1888, causou grande polêmica o projeto de criação de bancos de crédito real pelo governo, que se comprometeria a garantir até 300 mil contos de réis em créditos para a lavoura, cerca de duas vezes o valor total do meio circulante do país. O projeto foi considerado por Joaquim Nabuco e outros liberais 
fragilidade seus adversários liberais não hesitaram em explorar, logo acabou por comprometer a própria capacidade do partido em responder aos anseios daqueles que representava. $^{751}$

Enquanto os conservadores, no governo, não se mostravam capazes de definir uma agenda que reunisse o partido diante do fato irrevogável do colapso do escravismo, os liberais, na oposição, se rearticularam em torno de um projeto de descentralização e democratização política do país. A dimensão do abismo que separava os diferentes setores da elite política imperial ficou patente no dia da apresentação do novo ministério liberal à Câmara dos Deputados, após a queda de João Alfredo.

O gabinete de 7 de junho de 1889 era chefiado pelo senador mineiro Afonso Celso de Assis Figueiredo, desde o ano anterior visconde de Ouro Preto, que também ocupava a pasta da Fazenda, e composto por figuras destacadas do partido. Ocupava a pasta da Justiça o mineiro Cândido de Oliveira. Já o responsável pela pasta da Agricultura era o deputado alagoano Lourenço de Albuquerque. A pasta dos Negócios Estrangeiros ficou a cargo de José Francisco Diana, deputado riograndense, enquanto o ministério do Império foi ocupado por uma figura de destaque no Partido Liberal, mas que não tinha então assento no Parlamento, Franklin Dória, barão de Loreto, deputado pelo Piauí na $18^{\mathrm{a}}$ e $19^{\mathrm{a}}$ legislaturas e ligado a duas importantes lideranças do partido, Paranaguá e Saraiva. As duas pastas militares, por sua vez, foram entregues a oficiais: o visconde de Maracaju, General do Exército, ficou responsável pela Guerra, e o barão do Ladário, General da Armada, pela Marinha. ${ }^{752} \mathrm{O}$ gabinete apresentou à Câmara um programa amplamente reformista, inspirado no que fora acordado pela maioria dos delegados presentes no Congresso do partido, ocorrido semanas antes. Se alguns dos que oraram naquele dia declararam suas disposições reformistas excessivas e perigosas, outros já as consideravam

ainda pior que a indenização defendida por Paulino e Cotegipe. ACD. 26/06/1888, p. 398. A repressão da ociosidade foi também considerada uma prioridade pelo governo, com o ministro da Justiça, Antônio Ferreira Viana, apresentando projeto neste sentido. ACD. Sessão de 1888, tomo II, pp. 18-19. Dias antes, o liberal Afonso Celso Jr. apresentara projeto abolindo a pena de morte. Ibid., p. 19.

751 A fragilidade do ministério foi assinalada de forma irônica pela Gazeta de Notícias que, pouco antes de sua derrocada, apontou a desarmonia que reinava entre os ministros: "o programa do sr. Ferreira Viana no Club Beethoven foi - ser útil aos que tinham fome e sede de justiça; o do Sr. Tomás Coelho - dividir para reinar; o do sr. Costa Pereira foi condecorar, etc. Agora o sr. Conselheiro Prado [...] acaba de anunciar o seu novo programa, sem dúvida mais adiantado e mais progressista, porém ao que parece todo seu". A folha se referia a um discurso de Antônio Prado num banquete em sua homenagem, realizado em São Paulo, em que o então ministro da Agricultura declarou não se seduzir pelos "ouropéis da realeza". Ferreira Viana, Tomás Coelho e José Fernandes da Costa Pereira Jr. Ocupavam, respectivamente, as pastas da Justiça, da Guerra e dos Negócios do Império. Gazeta de Notícias. 03/03/1889, p. 1; Barão de Javari, op. cit., pp. 231-233.

752 Cf. Barão de Javari, op. cit., pp. 243-246; 373-400. 
insuficientes. $^{753}$

O presidente do Conselho narrou, à casa temporária, a conversa que tivera com o Imperador, quando convidado a organizar o novo gabinete. Agitando-se, segundo Ouro Preto, em "algumas províncias uma propaganda ativa, cujos intuitos são a mudança da forma de governo", propaganda que, "precursora de grandes males", era mister “enfraquecer" e "inutilizar", mostrava-se necessário proceder-se à

demonstração prática de que o atual sistema de governo tem elasticidade bastante para admitir a consagração dos princípios mais adiantados, satisfazer todas as exigências da razão pública esclarecida, consolidar a liberdade e realizar a prosperidade e grandeza da pátria, sem perturbação da paz interna em que temos vividos durante tantos anos. (Apoiados gerais.)

Chegaremos a este resultado, Senhor, empreendendo com ousadia e firmeza largas reformas na ordem política, social e econômica, inspiradas na escola democrática: reformas que não devem ser adiadas para não se tornarem improfícuas. O que hoje bastará, amanhã talvez seja pouco. ${ }^{754}$

Após ter o Imperador solicitado que o futuro chefe do gabinete "positivasse" as reformas pretendidas, este observara "que estavam compreendidas no programa aprovado pelo Congresso do partido liberal, ultimamente reunido nesta Corte", e do qual fora um dos “iniciadores”. Depois destas elucidações, Ouro Preto listou as reformas desejadas por seu governo:

Alargamento do direito de voto, mantido o alistamento vigente, e considerandose como prova de renda legal o fato do cidadão saber ler e escrever, com as únicas restrições do exercício de uma profissão lícita e do gozo dos direitos civis e políticos. Ampliação dos distritos eleitorais;

$[\ldots]$

Plena autonomia dos municípios e províncias. A base dessa reforma é a eleição dos administradores municipais e a nomeação dos presidentes e vice-presidentes de província, recaindo sobre lista organizada pelo voto dos cidadãos alistados.

$[\ldots]$

Efetividade das concedidas [sic] já concedidas por lei ao direito de reunião $;^{755}$

Liberdade de culto e seus consectários, medidas aconselhadas pela necessidade de facilitar a assimilação, na família brasileira, dos elementos estranhos provenientes

753 ACD. 11/06/1889, pp. 139-154.

754 Ibid., p. 141.

755 Aqui se se refere ao item III do programa do Partido Liberal de 1889, sobre o direito de reunião: "Garantia eficaz do direito, já reconhecido na constituição e nas leis, de se reunir o povo pacificamente e sem armas, para o fim de exprimir livremente o seu pensamento sobre os negócios públicos ou de representar as injustiças e vexações e o mau procedimento dos empregados públicos". A preocupação com o efetivo direito de reunião parece ter sido uma constante nos discursos e propostas dos parlamentares liberais ao longo da situação conservadora de 1885 a 1889. ACD. Sessões de 1886, 1887 e 1888; AS. Sessões de 1886, 1887 e 1888. 
da imigração, que convém fomentar na maior escala.

Temporariedade do Senado; ${ }^{756}$

$[\ldots]$

Reforma do Conselho de Estado, para constituí-lo meramente administrativo, tirando-se-lhe todo o caráter político;

Liberdade do ensino e seu aperfeiçoamento;

Máxima redução possível dos direitos de exportação;

Lei de terras que facilite a sua aquisição, respeitando o direito do proprietário;

Redução de fretes e desenvolvimento dos meios de rápida comunicação, de acordo com um plano previamente assentado.

Finalmente, animar e promover a criação de estabelecimentos de crédito, que proporcionem ao comércio, às indústrias e especialmente à lavoura os recursos pecuniários de que carecem. ${ }^{757}$

O primeiro a responder a Ouro Preto foi Augusto Olímpio Gomes de Castro, ${ }^{758}$ deputado conservador pelo Maranhão e um dos membros da dissidência "paulinista", que combatera o ministério João Alfredo. ${ }^{759}$ Após criticar a intervenção do "altíssimo" na transição política testemunhada, acusando o Imperador de prolongar deliberadamente a agonia do gabinete da abolição para impossibilitar a permanência da situação política conservadora, Gomes de Castro destacou que a sucessão ministerial pertencia a apenas um homem que, "nesta época de tanta aflição e incertezas, seria um símbolo de paz, e levaria o conforto e a esperança às classes espoliadas e perseguidas, que, há muito, clamam pela devida reparação". ${ }^{760}$ No lugar de Paulino de Souza, contudo, ascendia ao poder um gabinete liberal que, com as armas em riste, desejava vencer a república abrindo mão de tudo o que garantia a paz e a integridade nacional. Em vez de resistir à "revolução", restaurando a confiança das classes mais importantes no regime, o presidente do Conselho desejava chegar às raias da república:

756 Neste ponto, o orador foi interrompido pelo deputado conservador fluminense, Pedro Luiz Soares de Souza, que declarou: "É o começo da república". O presidente do conselho, então, respondeu ser a "inutilização da república", pois "sob a monarquia constitucional representativa podemos obter, com maior facilidade e segurança, a mais ampla liberdade". ACD. 11/06/1889, p. 142.

757 Ibid., pp. 141-142. Outros fins do gabinete seriam, segundo Ouro Preto, a elaboração de um código civil, a conversão da dívida externa, a amortização do papel-moeda, o equilíbrio da receita pública com a despesa e a fundação de estabelecimentos de emissão e crédito.

758 Ibid., pp. 143-145.

759 Diário de Notícias. 06/05/1889, p. 1.

760 ACD. 11/06/1889, p. 143. Vale recordar que, antes da queda da situação conservadora, haviam sido convidados pelo monarca a assumir a presidência do Conselho três importantes senadores do partido, Manuel Francisco Correia e os viscondes de Cruzeiro e de Vieira da Silva. Os dois primeiros não aceitaram organizar ministério e o último não conseguiu apoio suficiente entre seus correligionários para realizar a tarefa. Um ministério Paulino, por sua vez, era mais do que improvável, dada a oposição da maioria do país ao programa da indenização, considerado, além de tudo, impraticável frente às condições financeiras de então. 
Parece-me que uma política firme, mas calma, que respeitasse todos os direitos, e desse pronta satisfação às queixas justas e fundadas, que de todos os pontos se levantam, seria bastante para tranquilizar o espírito público, e restituir ao país a fé em sus instituições, a paz, pela qual ele anseia, e de que necessita para o seu progresso. (Apoiados.)

Vós feristes direitos garantidos pela magna carta das liberdades públicas; recusastes com uma tenacidade, que eu deploro, compor e reparar os danos causados pelas vossas reformas; levastes o desânimo e a descrença ao seio das classes mais interessadas na manutenção da ordem, aos melhores amigos da monarquia e do país; e quereis agora readquirir a confiança dessas classes, introduzindo no eleitorado todos quantos não forem analfabetos nem vagabundos, com atestados do inspetor de quarteirão, e elegendo os presidentes de província, por uma lista, que será organizada como entenderdes (apoiados); quereis consolidar a ordem pública, levantar o princípio da autoridade, que desfalece, soltando das mãos o meio que a lei constitucional vos dá para manter a unidade do Império. É tarde talvez, e com certeza não conseguireis por tais meios. ${ }^{761}$

Depois de agitar a questão servil, aliar-se ao movimento abolicionista e contribuir pra a "anarquia" generalizada cujo ápice fora a abolição incondicional, o Partido Liberal voltava agora ao poder decidido a impor às "classes mais interessadas na manutenção da ordem" um projeto que ia de encontro a tudo aquilo que almejavam, ou seja, o resgate da estabilidade e da autoridade do Estado, frente à sensível conflagração social que gerava um estado de permanente insegurança. Diante disto, Gomes de Castro indicou que recusaria conceder ao governo as leis orçamentárias, como era praxe, antes da dissolução. O ministério Ouro Preto não merecia confiança alguma, ficou declarado na moção apresentada pelo representante do Maranhão: “A Câmara dos Deputados, informada do programa do gabinete, recusa-lhe sua confiança". ${ }^{762}$ Antes de ser votada a moção, contudo, a virulência da sessão parlamentar atingiria níveis ainda mais extremos.

Sucedendo Gomes de Castro na tribuna, dois deputados declararam-se republicanos. O até então liberal mineiro José Cesário de Faria Alvim, representante da Zona da Mata mineira, acusou o ministério Ouro Preto de "enrolar a bandeira do partido", que seria a federação das províncias, e por isso declarava que iria se consagrar à causa da república. ${ }^{763}$ O deputado conservador pelo Rio Grande do Norte, padre João Manuel de Carvalho, por sua vez, adotou um tom feroz e dramático, que causou grande sensação pela dureza e ousadia de suas palavras. ${ }^{764}$

Em seu discurso acusatório, João Manuel, que pertencera à base governista de João

761 Ibid., p. 144.

762 Ibid., p. 145.

763 Ibid., pp. 145-146.

764 Ibid., pp. 146-149. 
Alfredo, ${ }^{765}$ não poupou ninguém, disparando contra a Coroa, contra as lideranças do governo e da oposição e contra o próprio sistema político do Império. Os partidos, "esfacelados pelos ódios, anulados pela fraqueza, apodrecidos pelos vermes das dissidências, que os têm corroído e dilacerado" atestavam, segundo João Manuel, a falência do sistema representativo. O Senado e o Conselho de Estado, "onde só deveriam imperar a calma, a reflexão, a prudência e a sabedoria", perdiam sua seriedade e contrariavam "os fins para que foram criados, tornando-se facciosos e revolucionários". Diante desta "dissolução dos partidos" e da "anarquia e desmoralização das instituições", o poder irresponsável tornava-se o "poder único, supremo e absoluto", tudo "mistificando" em nome da realização de seus desígnios; destruindo a situação conservadora, apoiada pela maioria da nação, para fazer ascender o partido adversário, por meio do qual desejava-se garantir o Terceiro Reinado, mesmo que através do uso da força. Tendo em vista esse estado de coisas, o deputado conservador não teve dúvidas em abandonar as instituições e dar vivas à república, no que foi contestado pelo presidente do Conselho. ${ }^{766}$

Joaquim Nabuco, monarquista insuspeito, foi o último a orar naquele dia. ${ }^{767}$ Ao ímpeto do conservador e neorrepublicanos que o precederam, Nabuco reagiu com um tom pessimista. Sendo o "iniciador da ideia federativa", o liberal pernambucano sentia-se obrigado a subir à tribuna, "desde que o Sr. Presidente do Conselho rasgou com as suas primeiras palavras a bandeira federal". ${ }^{768} \mathrm{O}$ Partido Liberal, que em Minas Gerais, São Paulo e Pernambuco era, segundo Nabuco, francamente federalista, cuja bancada majoritária havia, em 1885 e 1888, subscrito seu "projeto de monarquia federativa", 769 não podia agora se colocar aquém do que a própria Coroa já havia aceitado, a "independência das províncias". ${ }^{770}$ Sendo a ansiedade das províncias por sua completa autonomia muito grande, o presidente do Conselho teria imensos desafios pela frente. No entanto, Nabuco

765 Diário de Notícias. 06/05/1889, p. 1.

766 ACD. 11/06/1889, pp. 149-150.

767 Ibid., pp. 152-154.

768 Ibid., p. 152.

769 Para o projeto de monarquia federativa de autoria de Joaquim Nabuco, apresentado à Câmara dos Deputados em 14 de setembro de 1885, ver: Evaldo Cabral de Mello (org.), Essencial Joaquim Nabuco, pp. 195-229. Para a reapresentação do projeto à mesma Câmara, em 8 de agosto de 1888, ver: ACD. Sessão de 1888 , tomo 4 , p. 7.

770 Segundo o comentário da época, Saraiva, chamado antes de Ouro Preto para organizar o gabinete, havia exposto seu apoio à bandeira federal, levantada então por Rui Barbosa e setores do Partido Liberal. Segundo o próprio senador baiano, ele jamais falara em "federação" ao monarca, mas em amplo alargamento das franquias provinciais, a que o Imperador respondeu que jamais fora "embaraço para a vontade da nação, expressamente manifestada". Gazeta de Notícias. 12/06/1889, pp. 1-2. Alegando motivos de saúde, Saraiva se esquivou de organizar ministério, indicando o visconde de Ouro Preto, em seu lugar. 
declarou que manter-se-ia "com o povo", na posição de defesa da monarquia, "porque não há na república lugar para os analfabetos, para os pequenos, para os pobres”, não obstante considerar que o ministério poderia fazer mais no sentido da estabilidade democrática das instituições. ${ }^{771}$

Os imensos desafios que se apresentavam ao novo governo liberal devem ter ficado ainda mais evidentes quando o Conselho de Estado se reuniu para deliberar sobre o pedido de dissolução da Câmara feito pelo chefe de gabinete.

Na sessão, Paulino de Souza acusou o governo liberal de entregar as "trincheiras" voluntariamente ao "movimento desorganizador", em vez de contê-lo. Ignorando os desejos das "classes conservadoras, que mais peso têm no Estado, como a lavoura e o comércio", que não estavam "dominadas pelo espírito político das reformas apregoadas, tendo outras preocupações", os liberais perdiam pontos de apoio importantes na defesa das “instituições constitucionais":

As classes a que me refiro não se preocupam muito com a federação, mais ou menos genuína conforme quer esta ou aquela função do partido liberal, com a temporariedade do Senado e com as outras reformas radicais do programa do novo gabinete; pelo contrário, estimariam que, em vez de eletivos os presidentes de província continuassem a ser delegados de V. M. I., como manda a Constituição, e não se generalizasse a faculdade de influir pelo voto nas eleições às massas inconscientes do interesse público sem o amor da ordem e o espírito da liberdade, se a sua grande preocupação não fosse a reorganização do trabalho hoje anormal e incerto, a obtenção de capital que ninguém adianta para pagamento de salários, ou melhor, a regularidade do crédito indispensável para realização das operações que constituem a produção. ${ }^{772}$

Andrade Figueira, outro representante por excelência do que seu grupo político insistia chamar de "país real", isto é, a grande lavoura de exportação, admoestou, no mesmo sentido que Paulino, os adversários liberais por ignorarem tais interesses e desejarem governar com as "classes inferiores da sociedade". Cada uma das reformas apregoadas pelo programa do gabinete se afigurava "golpe profundo nas instituições fundamentais do país":

O alargamento do voto até o sufrágio universal direto entrega a monarquia desarmada às classes inferiores da sociedade, cujo pendor para as ideias radicais é

771 ACD. 11/06/1889, p. 153. Nabuco parece não ter deixado de apoiar o ministério até o fim. Já em setembro de 1889, o político pernambucano reafirmou sua boa vontade para com o governo, apesar de continuar insistindo na federação plena como essencial. MINISTÉRIO DE 1889. Correspondência oficial de Afonso Celso de Assis Figueiredo. AIHGB. Col. Ouro Preto, DL. 427.16.

772 Atas do Conselho de Estado. Terceiro Conselho de Estado. 15/06/1889. 
assaz conhecido. A monarquia ou se há de apoiar nas classes conservadoras da sociedade ou terá de desaparecer ante as invasões do espírito inovador.

A descentralização provincial pela eletividade dos presidentes de província ataca a centralização política sem a qual o governo imperial não poderá manter a unidade e a integridade nacional, que é o supremo benefício que ele pode continuar a prestar e principal razão justificativa de sua conservação.

A separação da igreja e do Estado, que é consectário natural e forçado [sic] da apregoada liberdade de cultos, priva a monarquia dos importantes direitos do Padroado e o império seu principal vínculo de união.

As reformas projetadas do Senado e do Conselho de Estado tendem ao mesmo fim de enfraquecer o governo monárquico privando-o de importantes pontos de apoio e preparando eficazmente a mudança da forma de governo.

Em presença de um tal programa de governo, é muito para recear-se que as próprias classes conservadoras da sociedade venham a nutrir dúvidas sobre $\mathrm{o}$ propósito da monarquia em sustentar com firmeza o seu glorioso papel de manter a unidade e a integridade da pátria; e daí poderá resultar entibiar-se-lhes o zelo na sua defesa se não pactuarem, descrentes, com o espírito inovador. O partido conservador pode entender que só lhe incumbe manter a monarquia com a plenitude das atribuições decretadas na Constituição Política do Império e não a monarquia mutilada pelas reformas projetadas; a monarquia capaz de salvar a unidade e a integridade nacional e não impotente para assegurar-lhes o seu supremo bem, que ele bem pode esperar de uma república unida. Não será para estranhar que o desvairado venha a fazer por conviç̧ão o que os seus adversários fizeram por especulação para empolgarem o poder. $^{773}$

O tom ameaçador de tais declarações tornou-se ainda mais explícito nas palavras de uma outra importante liderança conservadora que, diferentemente de seus correligionários fluminenses, não rejeitava, a princípio, a solução federal. Alguns dias depois de a Coroa consentir na dissolução da Câmara dos Deputados, Antônio Prado, em entrevista a uma folha da Corte, sugeriu ser a república apenas uma questão de tempo. ${ }^{774}$ Diante da impossibilidade de se realizar a união do Partido Conservador para a formulação de um programa comum, Prado se via obrigado a fazer apenas "política provincial", o que, segundo o senador, significava a conversão do Partido Conservador de São Paulo à federação. A este resultado teria sido levado também pela impossibilidade de compor com o gabinete liberal, que fazia política puramente "partidária":

Eu julgava que se poderia iniciar um programa assaz largo, que pudesse merecer o apoio da maioria da nação, que então formaria o partido nacional; mas, à vista do caráter partidário da organização Ouro Preto, que é um ministério exclusivamente de partido, vi logo que a minha ideia estava prejudicada. ${ }^{775}$

773 Ibid.

774 Gazeta da Tarde. 22/06/1889, p. 2.

775 Ibid., p. 2. 
"Deficientes", as reformas pretendidas pelos liberais colocavam-no em "divergência capital com o honrado presidente do Conselho". Diante da situação política do país, Prado adotava um tom fatalista:

Julgo [...] que a monarquia tem os seus dias contados no Brasil e que o advento da república é infalível. O sr. visconde de Ouro Preto, pelo contrário, pensa suplantar o movimento republicano por uma série de reformas democráticas, assaz adiantadas. Em tal caso entendo que o partido conservador, não podendo obstar mais ao advento da república, devia formular um programa assaz largo de reformas tais, que, realizadas, a passagem da monarquia para a república se fizesse sem abalo sensível. É por isso que eu quero muito mais que o programa de Ouro Preto.

$[\ldots]$

Se o partido conservador se unisse para adotar uma política descentralizadora, que garantisse a autonomia das províncias, eu daria preferência a essa política; mas, desde que essa união se verificou impossível, e que sou forçado a fazer política provincial, devo ser federalista, por ser a forma mais simples e perfeita da separação entre os interesses gerais e provinciais, embora esteja convencido de que a federação trará como consequência necessária a república, mais cedo do que eu desejava que ela se estabelecesse no Brasil. ${ }^{776}$

Não obstante as diferenças que os separavam, algumas relações podem ser estabelecidas entre os pareceres dos conservadores fluminenses e a entrevista concedida por Antônio Prado. Mais do que encarar de forma pessimista o futuro das instituições monárquicas, eles repudiavam a política ministerial, considerando-a perniciosa ao incorporar as supostas bandeiras do "movimento desorganizador". "Partidários", os liberais, no lugar de compor com seus adversários, escolhiam a realização de reformas "radicais", que não visavam a resgatar a estabilidade político-institucional do Império, mas a contemporizar com as bandeiras dos "inovadores", avançando um programa próprio. Incapazes de, devido às suas divisões sensíveis, impor resistência ao que almejavam seus adversários, esses conservadores adotavam uma retórica profundamente fatalista, alertando para a inevitabilidade da república, devido à perda de apoio, entre as classes mais importantes da nação, que supostamente representavam, sofrida pelo regime monárquico. Nesses termos, Prado, ao aceitar a "inevitabilidade" da federação e da república, deixava implícito que a nova organização político-institucional do país por ele desejada nada tinha que ver com o programa democrático dos adversários. Era o Partido Conservador que deveria "formular um programa" que realizasse a transição "sem abalo sensível" para a república. A mudança de regime, nesses termos, era colocada como menos prejudicial a 
seus interesses e à estabilidade do país do que o sucesso do projeto monárquico federalista democrático avançado pelos adversários.

Nada mais distinto do que, semanas antes, o líder da ala "radical" do Partido Liberal, Manuel Pinto de Souza Dantas, declarara na presença do Imperador:

É de notoriedade o movimento crescente da opinião por grandes e amplas reformas, entre as quais avultam a do alargamento do voto e as do governo local, autonomia ou federação das províncias.

Não compreendo, no nosso estado de coisas, senão a adoção franca e sem tergiversação da política de resistência a tais aspirações, ou a das reformas mais largas e completas, por que se mostre e se convença a opinião nacional que a nossa forma de governo oferece toda a elasticidade desejável para estabelecer e firmar o consórcio da monarquia com a democracia, o que vale a observância e a prática do princípio consagrado na nossa constituição, de que todos os poderes são delegação da nação. Esta é, a meu ver, a política mais acertada para o Brasil presentemente. ${ }^{77}$

O projeto que esposavam os liberais para o país havia sido historicamente um projeto de maior autonomia das partes, com destaque para o autogoverno local (entenda-se o princípio da eletividade dos cargos) e de incorporação gradual de setores crescentes da sociedade ao sistema político formal. ${ }^{778}$ Este projeto era herdeiro do federalismo defendido pelos liberais da década de 1830, que, com reformas fundamentais do arcabouço políticoinstitucional recebido do Primeiro Reinado, haviam sido capazes de transformar o Império do Brasil num regime de tipo federativo, com legislativos provinciais e a consequente divisão de competências entre centro e partes. O aprofundamento deste arcabouço, com importantes nuances, se manteve subjacente às perspectivas do Partido Liberal ao longo de todo o Segundo Reinado, vindo à tona em diversos momentos, ao se tratar de diversos temas, de forma mais ou menos radicalizada.

Dado o caráter negociado da política imperial, ele, obviamente, nunca pôde se realizar por completo. Nem mesmo nos idos anos 1830 fora possível extinguir o Senado vitalício ou o Poder Moderador. ${ }^{779}$ A história da legislação eleitoral do Império é bastante ilustrativa disto: a Lei Saraiva, como vimos, por exemplo, teve muito de seu caráter descentralizador neutralizado e se tornou bastante mais restritiva após as emendas

777 Atas do Conselho de Estado. Terceiro Conselho de Estado. 31/05/1889.

778 Cf. Miriam Dolhnikoff, O pacto imperial; Id., "Representação na monarquia brasileira”; Id., "Governo representativo e legislação eleitoral no Brasil do século XIX”; Monica Duarte Dantas, "O código do processo criminal e a reforma de 1841: dois modelos de organização do Estado (e suas instâncias de negociação".

779 A temporariedade do Senado e o fim do Poder Moderador, previstos no projeto original do Ato Adicional foram barrados pela câmara alta. Cf. Miriam Dolhnikoff, O pacto imperial, cap. 2 "O arranjo institucional". 
propostas pelos conservadores, sem cujo concurso não seria possível aprová-la na câmara alta, onde havia maioria do Partido de Paulino e Cotegipe. ${ }^{780}$ Isto não significava, por outro lado, que a contribuição do projeto liberal para o edifício político-institucional do Império fosse reduzida. A própria Lei Saraiva, com seus distritos uninominais e o censo eleitoral do votante, foi capaz de abrir caminho, de forma bastante tortuosa, é verdade, para uma maior participação do eleitorado na vida política do país, estabelecendo um contato mais íntimo entre eleitores e candidatos e habituando de vez o país às campanhas eleitorais popularizadas, especialmente nos grandes centros urbanos. Abriu, ainda, possibilidades para o questionamento do papel sobressaliente das grandes lideranças partidárias, tornando a antiga bandeira liberal da temporariedade do Senado mais palpável do que nunca.

Para além de disputas em torno do sistema eleitoral, a década de 1880 foi marcada por um rápido processo de popularização da política que, por diversos motivos, se ligou visceralmente à luta pela abolição da escravidão. Esta união visceral transformou o horizonte político do Império, possibilitando que, pela primeira vez, a bandeira da libertação dos escravos estivesse diretamente ligada a um projeto efetivo de democratização política do país, historicamente esposado pela ala mais radical do Partido Liberal. ${ }^{781}$ Graças a tal união, radicais e abolicionistas se fortaleceram mutuamente, impondo ao Partido Liberal uma agenda democrática sem precedentes, que tinha na extinção rápida da escravidão um ponto central, mas que perpassava uma série de temas e expectativas que iam muito além da abolição. Promovida a libertação dos escravos, tal agenda pôde ter vazão e um esforço de rearticulação nacional do partido resultou no programa de 1889, que se não ia tão longe quanto queriam alguns dos mais radicais, era bastante mais avançado do que aquele que tinham em vista quando retornaram ao poder pela primeira vez desde rearticulados, no ano de 1878. Em menos de uma década, a generalização do sufrágio, a eletividade dos presidentes de província, a temporariedade do Senado, a reforma do Conselho de Estado e, mesmo, a difusão do acesso à terra, eram realmente palpáveis, incluídas num programa ministerial, e dependiam apenas da aprovação parlamentar para serem realizadas, num momento em que o Partido Conservador se mostrava extremamente fragilizado, com reduzida capacidade de obstar as reformas dos adversários. As atenções do país se voltaram, então, à campanha para a eleição geral marcada para o final de agosto. 
Poucas semanas após a entrevista concedida, à Gazeta da Tarde, por Antônio Prado, o maior representante da ala dura do Partido Conservador sugeriu publicamente que, diante da incapacidade da agremiação em resistir às reformas planejadas por seus adversários, não via mais como rechaçar a marcha do "princípio inovador". Destacando a adesão de muitos de seus comprovincianos ao "novo credo", Paulino de Souza lançou um manifesto aos eleitores do Rio de Janeiro em que apontava acidamente o extremo a que havia chegado a situação política do país:

Acautelando a desorganização iminente, o partido conservador procurou na defesa do direito à indenização o meio de manter nas classes laboriosas a esperança de verem atendidos importantes interesses acintosamente postergados, ao passo que o partido liberal tentava levantar simpatias nas províncias com a promessa de franquezas e concessões políticas mais ou menos atentatórias da autoridade constitucional do poder central. A coincidência da apresentação positiva deste plano com a recente mudança de situação política e consecutiva inversão das posições oficiais, repentinamente transferidas em todo o império de um para o outro partido, trouxe logo grande proselitismo às ideias de federação mais ou menos caracterizada, em cujo triunfo viram as províncias o meio de se resguardarem das perturbações determinadas pelas reações partidárias, subitamente originadas do ato de uma única vontade. A eletividade dos presidentes de província e outras ideias suscitadas no congresso liberal acharam adesões explicáveis nos próprios adversários do partido que com elas acabava de alcançar a confiança da coroa. ${ }^{782}$

Considerando a eletividade dos presidentes de província em desacordo com os preceitos constitucionais, mas reconhecendo que fora vencido na questão, Paulino destacou a importância de intervenção na definição das atribuições dos presidentes eletivos e na "reforma consequente das outras leis orgânicas que o partido conservador poderá pesar para preservar-se a unidade nacional e firmarem-se na nova ordem política e administrativa os lineamentos de uma organização conveniente". Tendo ido o gabinete Ouro Preto ao encontro do "movimento radical", com o plano de "apaziguá-lo e satisfazê-lo com a cessão das mais seguras linhas de trincheiras e parecendo-lhe ser já o caso de concentrar a resistência no último reduto, a instituição monárquica, pelos mesmos defensores desguarnecidos das suas melhores fortificações", o senador fluminense não acreditava que fosse possível prosseguir o governo com tal plano diante da nova Câmara. Esta, cuja feição era pouco previsível poderia "arrastá-lo" ao extremo, a não ser que lhe coubesse "a ventura, pouco invejável, de apoiar-se em uma maioria amorfa e apta para todos os feitios, pronta a dizer não quando a tenham encarregado de dizer sim, como aconteceu à última legislatura 
que votou a abolição imediata e sem cláusulas", mesmo tendo sido eleita para manter-se na resistência. Poderia ser ainda pior se o ministério, comedido, deixasse de ser tolerado pela "vivacidade da opinião liberal". Em tal contexto, o esforço de um debilitado Partido Conservador em resistir poderia exauri-lo a ponto de que suas forças políticas ficassem completamente comprometidas. Era melhor que ele, então, tomasse alguma iniciativa:

No estado atual dos espíritos, qual se me afigura, a resistência formal do partido conservador poderá dar o efeito desastroso de inutilizar desde logo valiosíssima força política, capaz de conseguir muito, se não for logo arredada da arena como corpo inerte, repelida e posta fora de combate.

Assim, pois, capacitado de ter passado o ensejo de resistir adequadamente às invasões do princípio inovador, estou por minha parte resolvido a não exclui-lo preliminarmente e de plano, mas a acompanhá-lo atentamente e a tomar parte no movimento para contribuir quanto em mim couber, para a sua regularização constitucional e manter sempre vivaz a ideia conservadora na esperança de vê-la poderosamente secundada, como há de ser, pelo bom senso da nação, dominando em breve tempo os acontecimentos. ${ }^{783}$

Os dois principais chefes políticos conservadores de São Paulo e do Rio de Janeiro, apesar de suas desinteligências, mostravam-se dispostos a não resistir, ou até mesmo sustentar uma mudança de regime. Frente à possibilidade de que os planos reformistas do gabinete fossem levados a cabo, ou pior, que os radicais do partido levassem-no a extremos imprevisíveis, o esforço necessário para a defesa das posições conservadoras ganhava outra intensidade. Com os liberais no controle do Poder Executivo e, num futuro muito próximo, potencialmente dominantes no Legislativo, o que se somava à incapacidade já demonstrada pela Coroa em resistir a seus projetos, a ruptura com a ordem legal, mesmo que por apoio tácito ao "novo credo", se apresentou como uma possibilidade crescentemente viável, diante do desprestígio do regime entre as "classes conservadoras".

De fato, nas províncias de São Paulo e Rio de Janeiro, as adesões de conservadores ao republicanismo, manifestadas explicitamente ou tacitamente por meio do voto, se mostraram bastante consideráveis na eleição subsequente. ${ }^{784}$ No Vale do Paraíba fluminense, Andrade Figueira e Ferreira Viana não se candidataram e recomendaram abstenção a seus eleitores. ${ }^{785}$ Lá se assistiu a vitórias liberais nos três distritos eleitorais da região. No $12^{\circ}$ distrito, com sede em Itaguaí, o filho de Paulino de Souza foi derrotado, em

\footnotetext{
783 Ibid., p. 3.

784 Boletins eleitorais diários foram divulgados pelos jornais da Corte. Ver, em especial: O Paiz e Diário de Notícias. Agosto a outubro de 1889. 785 O Paiz. 08/10/1889, p. 3.
} 
segundo escrutínio, pelo candidato liberal. Todas estas eleições tiveram a participação de candidatos republicanos que parecem ter deslocado votos das candidaturas conservadoras. Em distritos onde se concentrava o poder político de Paulino, seu fracasso ficou evidente. No $7^{\circ}$ distrito, região de Cantagalo, onde o chefe fluminense tinha propriedades agrícolas e "numerosa clientela", o Partido Liberal mostrava força e os conservadores só conseguiriam vitória em $2^{\circ}$ escrutínio caso realizassem "união com os republicanos". Nos $6^{\circ}$ e $9^{\circ}$ distritos, apesar de candidaturas liberais de pouca monta, os conservadores não conseguiam resultados positivos. Diante deste quadro crescia a aceitação de alianças com republicanos. ${ }^{786}$

Em São Paulo, a vitória liberal também foi acachapante, com o partido triunfando em oito dos nove distritos da província. O voto conservador parece ter ido em parte considerável para os candidatos republicanos em diversos destes distritos. ${ }^{787}$ Lideranças do Partido Republicano, inclusive, passaram a defender alianças com os conservadores, visando a impedir a avalanche liberal. A Província de São Paulo lançou editorial incentivando tais acordos, destacando que

[o] grosso do partido conservador paulista [...] pronuncia-se pela liga com a oposição radical. Não faz disto mistério, anuncia-a com firmeza e realiza-a com lealdade. Não se arreceia dos comprometimentos anti-dinásticos, nem das antipatias dos interessados na manutenção da monarquia.

$[\ldots]$

Para o partido conservador a liga é oportuna, conveniente e até mesmo política, como ameaça à situação que se abriu, eliminando-o do parlamento e dos cargos de administração.

Para o partido republicano, mesmo no terreno das conveniências partidárias, como único meio de arregimentação, será útil e vantajosa a liga?

É questão que só o alto critério dos chefes pode resolver.

E eles que a aconselharam com altivez e franqueza é porque assim a julgam. ${ }^{788}$

As perspectivas mais sombrias dos conservadores realmente se confirmaram no decorrer da eleição. O desempenho dos candidatos republicanos também ficou muito abaixo do esperado. Entre as províncias centrais, Bahia e Pernambuco tiveram vitórias

\footnotetext{
786 O Paiz. 09/09/1889, p. 2. Quintino Bocaiuva, por sua vez, defendeu explicitamente alianças eleitorais entre conservadores e republicanos na província. Id. 03/09/1889, p. 1.

787 Os conservadores só chegaram ao segundo escrutínio em um dos distritos da província, vencendo com Delfino de Ulhoa Cintra. No $5^{\circ}$ distrito, com sede em Itapetininga, outro conservador prestigioso, conselheiro Manuel Antônio Duarte de Azevedo, sofreu uma derrota humilhante, angariando apenas 147 votos, cerca de $10 \%$ do total. Francisco de Paula Rodrigues Alves, ex-presidente da província, também foi derrotado pelo adversário liberal. O Paiz. Agosto e Setembro de 1889.

$788 \mathrm{O}$ artigo foi reproduzido n'O Paiz. 08/10/1889, p. 3.
} 
liberais em todos os seus distritos. ${ }^{789}$ Em São Paulo, apenas um distrito não elegeu candidato liberal. No Rio de Janeiro, o pior pesadelo de Paulino: ampla maioria liberal e apenas nomes deste partido na lista tríplice senatorial. ${ }^{790} \mathrm{Em}$ Minas, as eleições se mostraram mais acirradas, mas diversas previsões cravavam maioria de liberais, seguidos de republicanos e conservadores, nesta ordem. ${ }^{791}$ No geral, folhas da Corte fizeram previsões para o resultado final do pleito, após a realização de segundo escrutínio em diversos distritos, que davam cerca de 100 cadeiras na Câmara aos liberais, contra 20 aos conservadores e 5 aos republicanos. ${ }^{792}$ Ficava evidente que, não obstante a possível formação de dissidências no seio da maioria, Ouro Preto teria números suficientes para fazer aprovar seu programa, até mesmo no Senado.

A partir de setembro, foram levados a público alguns dos projetos fundamentais que o governo apresentaria ao Parlamento, o primeiro deles, prioridade do ministério, tratava das eleições. As disposições da reforma eleitoral pretendida eram ainda menos restritivas do aquelas previstas no programa do partido. ${ }^{793}$ Ao considerar "como tendo a renda legal para exercerem o direito de voto nas eleições todos os cidadãos brasileiros que tiverem a idade de 21 anos completos, souberem ler e escrever e estiverem no gozo de seus direitos políticos", retirava-se do rol das exigências para se tomar parte nos pleitos comprovar o cidadão ter "profissão lícita". Além disso, em casos especiais, menores de 21 anos poderiam integrar o eleitorado, com a condição de que fossem casados, doutores ou bacharéis, exercessem emprego público ou fossem jurados, desde "pelo menos um ano antes do alistamento". A prova de alfabetização, por sua vez, não parecia ser especialmente rígida, prevendo-se, ainda por cima, que seria julgada por funcionários da localidade, como

789 Apenas em poucos distritos das duas grandes províncias do Norte houve candidatos republicanos, geralmente recebendo pouquíssimos sufrágios. Em diversas regiões, as vitórias liberais sobre importantes candidatos conservadores foram acachapantes. Nos dois distritos do Recife, José Mariano e Joaquim Nabuco receberam um número de votos mais de cinco vezes superior ao de seus adversários conservadores. No $5^{\circ}$ distrito da Bahia, região de Itaparica e Nazaré, José Marcelino de Souza, deputado conservador na $20^{\circ}$ legislatura e que teria grande destaque na política da região durante a república, recebeu apenas três votos, o que sugere uma ampla abstenção conservadora. O Paiz. Agosto, setembro e outubro de 1889.

790 Eram eles os liberal-abolicionistas Adolfo Bezerra de Menezes e Manuel Rodrigues Peixoto, bem como Eduardo de Andrade Pinto, figura ligada a Francisco Otaviano, recém-falecido. Na Bahia, o pesadelo conservador não foi menor: a vaga deixada pelo falecimento do barão de Cotegipe seria ocupada por ninguém menos que o ex-ministro da Agricultura de Dantas, Antônio Carneiro da Rocha, ligado à ala radical do Partido Liberal. Visconde de Ouro Preto a José Antônio Saraiva, 1889 (confidencial). AIHGB. Col. Saraiva, DL 274.17.

791 O Paiz. Setembro e outubro de 1889. Segundo George Boehrer, nos momentos finais do Império, Minas Gerais ainda era majoritariamente monarquista, com os republicanos representando cerca de $30 \%$ do eleitorado. Cf. George Boehrer, op. cit., p. 145.

792 O Paiz e Diário de Notícias. Outubro de 1889.

793 O projeto foi publicado por O Paiz. 14/09/1889, p. 1. 
se lê no art. $4^{\circ}$ :

A condição de saber ler e escrever será provada pela letra e assinatura do cidadão, que requerer a sua inclusão no alistamento, reconhecidas na respectiva petição por tabelião de notas ou escrivão de paz. ${ }^{794}$

Por fim, o projeto suprimia o segundo escrutínio para a eleição de deputados à Assembleia Geral e às Assembleias Provinciais, adotando um sistema em que se consideraria eleito "o cidadão que obtiver maioria de votos dos eleitores que concorrerem à eleição". 795

Outro projeto a ser apresentado era o de naturalização dos cidadãos estrangeiros, que seria bastante simplificada. Dispunha-se que seria considerado "cidadão brasileiro para todos os efeitos legais, como se nato fosse, todo o estrangeiro" que residisse no Império por espaço de dois anos consecutivos e que seis meses "depois desse tempo e da promulgação desta lei não fizer declaração de que quer conservar a sua nacionalidade". A prova de residência a ser apresentada pelos que desejassem naturalização às autoridades poderia ser a atestação de "pároco, subdelegado de polícia ou juiz de paz da paróquia ou distrito em que residir o cidadão". 796

A pretendida reforma da administração provincial também foi publicizada. Como previsto no programa liberal, os presidentes seriam nomeados a partir de listas organizadas pelos eleitores. O Município Neutro foi separado da província e estava prevista a criação de prefeito e Conselho Geral para a Corte, eleitos do mesmo modo e com as mesmas prerrogativas que os presidentes de província e as Assembleias Provinciais. No que dizia respeito às funções e jurisdição dos presidentes, foram plenamente aplicadas as disposições do Ato Adicional. ${ }^{797}$

Às reformas citadas deveriam, muito provavelmente, seguir a temporariedade do Senado, a reforma do Conselho de Estado, a nova Lei de Terras, cujo objetivo principal, inscrito no programa do governo, seria a facilitação a seu acesso, ${ }^{798}$ bem como outras

794 Ibid., p. 1. As certidões seriam, posteriormente, enviadas para avaliação do juiz de direito.

795 Ibid., p. 1.

796 O Paiz. 21/09/1889, p. 1.

797 Cf. Elpídio de Mesquita, op. cit.

798 Não é ocioso recordar que Ouro Preto subscrevera o projeto abolicionista de Dantas, em 1887, que previa a criação de colônias agrícolas para libertos nas margens de estradas de ferro e rios navegáveis, onde se tornariam gradualmente proprietários de lotes de terra. Nesse mesmo sentido, a historiografia já revelou a existência de planos, acordados entre a Princesa Imperial, o senador Dantas, Joaquim Nabuco e outros abolicionistas importantes, de concessão de terras a ex-escravos, como "indenização" pelo cativeiro. A 
propostas que, como vimos, eram consideradas inaceitáveis por importantes lideranças conservadoras e pelas "classes" que representavam, cuja deserção com relação ao regime parece ter tomado uma intensidade extraordinária na segunda metade de 1889.

Pelo que foi exposto até aqui, parece seguro apontar que no momento em que a questão servil foi retirada de seu cativeiro institucional e transformada na prioridade absoluta do país, as divisões programáticas e ideológicas entre os partidos políticos não se mostraram opacas ou inexistentes. Pelo contrário, esse novo estado de coisas suscitou um realinhamento importante, tornando as distâncias que os separavam ainda mais palpáveis, também pelo fato fundamental do sensível crescimento de suas alas mais radicalizadas, especialmente no caso do Partido Liberal. Talvez a força e influência do radicalismo liberal não tivesse se mostrado tão intensa desde os combates da década de 1830, quando essa ala do partido foi capaz de propor reformas estruturais na organização do Estado. Deste modo, não parece coincidência que se insistisse tanto, dentro da agremiação, na década de 1880, na reivindicação da herança das reformas daquele decênio, sob a máxima da "restauração do regime democrático". 799

Essas profundas distensões existentes na sociedade brasileira de fins da década de 1880 eram testemunhadas no abismo entre, por um lado, um projeto liberal-abolicionista que tinha no federalismo democrático com a difusão da propriedade fundiária seu horizonte, e, por outro, as expectativas desencontradas de um conservadorismo mais ou menos reacionário em visceral oposição às transformações fundamentais pelas quais passava o país. Se ambos os partidos monárquicos não gozavam de coesão interna sobre como avançar seus projetos ou resistir à avalanche, não parece possível ignorar que as perspectivas que possuíam eram muito distintas, com os liberais esposando majoritariamente o primeiro projeto citado e os conservadores protagonizando a tentativa de resistência e reorganização do Império em termos completamente diferentes daqueles pretendidos por seus adversários, até que não foi mais possível.

Pode-se aventar, nesse sentido, que o abandono do regime por importantes lideranças conservadoras, algumas delas aderindo explicitamente ao republicanismo, como foi o caso

partir da abertura das Câmaras, planejada para 20 de novembro de 1889 , se poderia dar prosseguimento a tais planos, afirmava Isabel, em sua correspondência privada. Contudo era preciso sigilo absoluto: "Deus nos proteja se os escravocratas e militares saibam desse nosso negócio, pois seria o fim do atual governo e mesmo do Império e da Casa de Bragança no Brasil". Apud Priscilla Leal, "O lado rebelde da Princesa Isabel", in Nossa História, ano 3/ n 311, maio de 2006, pp. 69-72. Citado por Maria Luiza de Carvalho Mesquita, O “Terceiro Reinado”: Isabel de Bragança, a Imperatriz que não foi. Dissertação de Mestrado em História Social, Vassouras: USS, 2009.

799 Tribuna Liberal. 01/12/1888, p. 1. 
de barão de Lucena, em Pernambuco, ou de membros da tradicional família Lacerda Werneck, no Rio de Janeiro, ${ }^{800}$ contribuiu extensamente para as perspectivas de subversão do regime monárquico. Reforça esta proposição o fato de o Golpe de Estado republicano ter ocorrido justamente na manhã do dia 15 de novembro, data em que se iniciariam os trabalhos preliminares do Parlamento para sua sessão de abertura oficial, prevista para cinco dias depois. Corroboram, ainda, o que foi até aqui aventado as rápidas adesões de conservadores em algumas das províncias mais importantes do Império, como São Paulo e Bahia, ao novo regime, pouco depois de recebidas as notícias que vinham do Rio de Janeiro. $^{801}$

Frente ao domínio liberal das instituições monárquicas, a subversão do regime vinha à tona como a opção mais segura para, segundo o mais insuspeito dos apóstolos da ordem, Paulino de Souza, "manter sempre vivaz a ideia conservadora na esperança de vê-la poderosamente secundada, como há de ser, pelo bom senso da nação, dominando em breve tempo os acontecimentos". ${ }^{802}$ Nesses termos, se afigura relevante questionar até que ponto o golpe republicano e o regime que lhe seguiu foram resultantes mais de um realinhamento de forças conservadoras do que de um movimento militar de subversão da ordem monárquica.

800 Cf. Eduardo Silva, Barões e escravidão, Rio de Janeiro: Nova Fronteira; Brasília: INL, 1984; O Paiz. Agosto, setembro de outubro de 1889. Consta que Lucena, presidente da Câmara durante o governo João Alfredo, declarou-se republicano após a apresentação do ministério Ouro Preto.

801 Segundo Campos Sales, nas vésperas do golpe militar, Antônio Prado já se havia mostrado, reservadamente, favorável à opção republicana. O senador paulista seria o primeiro entre os chefes nacionais dos dois partidos monárquicos a aderir ao novo regime, por meio de seu jornal. Correio Paulistano. 18/11/1889, p. 1. Na Bahia, após ser noticiado o movimento militar ocorrido no Rio de Janeiro, os conservadores abandonaram reunião com o presidente liberal da província, Almeida Couto, deixando implícita sua adesão ao novo regime, ou ao menos seu desinteresse em resistir-lhe. Cf. Luiz Henrique Dias Tavares (org.), op. cit., p. 28.

802 Gazeta de Notícias. 11/07/1889, p. 3. 


\section{Fontes}

\section{Institucionais}

Disponíveis em http://www2.camara.leg.br/:

-Anais da Câmara dos Deputados, 1878-1889.

-Coleção da Leis do Império do Brasil, décadas de 1870 e 1880.

Disponíveis em http://www.senado.gov.br/:

-Anais do Senado, 1878-1889.

-Atas do Conselho de Estado, 1881-1889.

Periódicos (disponíveis em http://bndigital.bn.br/hemeroteca-digital/)

\section{Rio de Janeiro}

-Brazil (1884-1885)

-Diário de Notícias (1884-1889)

-Gazeta de Notícias (1881-1889)

-Gazeta da Tarde (1884-1889)

-O Paiz (1881-1889)

-Tribuna Liberal (1888-1889)

\section{São Paulo}

-Correio Paulistano (1880-1889)

\section{Fundos Privados}

Instituto Histórico e Geográfico Brasileiro

-Arquivo Wanderley Pinho

-Coleção Arquivo Histórico

-Coleção Barão de Cotegipe

-Coleção Barão de Loreto

-Coleção Baronesa de Loreto

-Coleção Hélio Viana

-Coleção Francisco Belisário 
-Coleção Prudente de Morais

-Coleção Rodrigues Alves

-Coleção Saraiva

-Coleção Soares Brandão

-Coleção Sousa Leão

-Coleção Vieira da Silva

-Coleção Visconde de Ouro Preto

\section{Arquivo Histórico do Museu Imperial}

-Arquivo da Casa Imperial

-Arquivo do Grão-Pará

-Coleção João Alfredo

-Coleção Sinimbu

\section{Arquivo Nacional}

-Coleção Prudente de Morais

\section{Biblioteca Nacional}

-Arquivo Tobias Monteiro

\section{$\underline{\text { Impressas }}$}

CARREIRA, Liberato de Castro. História financeira e orçamentária do Império do Brasil; Brasília: Senado Federal/ Rio de Janeiro: Fundação Casa de Rui Barbosa, 1980.

JAVARI, Barão de. Organizações e programas ministeriais; regime parlamentar no Império ( $3^{\mathrm{a}}$ ed.). Brasília: Departamento de Documentação e Divulgação, 1979.

MELO, Américo Brasiliense de Almeida e. Os programas dos partidos e o Segundo Império, Brasília: Senado Federal; Rio de Janeiro: Fundação Casa de Rui Barbosa, 1979.

MESQUITA, Elpídio de. Dois Regimens. São Paulo: Typ. Leuzinger, 1896.

MORAES, Evaristo de. Da Monarquia para a República (1870-1889), São Paulo: Athena, 19--.

NABUCO, Joaquim. "O abolicionismo", in Evaldo Cabral de Mello (org.), Essencial Joaquim Nabuco, São Paulo: Penguin Classics Companhia das Letras, 2010, pp. 35-112. 
"O erro do imperador", in Evaldo Cabral de Mello (org.), Essencial Joaquim Nabuco, São Paulo: Penguin Classics Companhia das Letras, 2010, pp. 163-180.

Projeto de monarquia federativa [discurso de 21 de setembro de 1885], in Evaldo Cabral de Mello (org.), Essencial Joaquim Nabuco, São Paulo: Penguin Classics

Companhia das Letras, 2010, pp. 195-229.

SACRAMENTO BLAKE, Augusto Victorino. Diccionario bibliographico brazileiro, Rio de Janeiro: Conselho Federal de Cultura, 1970.

SOUZA, Francisco Belisário Soares de. O sistema eleitoral no Império. Brasília: Senado Federal, 1979. 


\section{Bibliografia}

ADUCCI, Cássia Chrispiniano. A "Pátria Paulista": o separatismo como resposta à crise final do Império Brasileiro, São Paulo: Arquivo do Estado/Imprensa Oficial, 2000.

AGUIAR, Alexandra do Nascimento. As eleições do mérito: campanha eleitoral de 1881. Dissertação de Mestrado em História Social, São Gonçalo: UERJ, 2009.

ALONSO, Angela. Flores, Votos e Balas: o movimento pela abolição da escravidão no Brasil, Tese de Livre-docência, São Paulo: FFLCH-USP, 2012.

“Associativismo avant la lettre - as sociedades pela abolição da escravidão no Brasil oitocentista", Sociologias, Porto Alegre, ano 13, n 28, set./dez. 2011, pp. 166-199.

Ideias em movimento: a geração de 1870 na crise do Brasil-Império, São Paulo: Paz e Terra, 2002.

Joaquim Nabuco: os salões e as ruas. São Paulo: Companhia das Letras, 2007.

ANDRADE. Manuel Correia de. João Alfredo: o estadista da abolição. Recife: FUNDAJ, Editora Massangana, 1988.

AZEVEDO, Célia Maria Marinho de. Onda negra, medo branco: o negro no imaginário das elites - século XIX, Rio de Janeiro: Paz e Terra, 1987.

AZEVEDO, Elciene. O direito dos escravos. Lutas jurídicas e abolicionismo na província de São Paulo na segunda metade do século XIX. Tese de Doutorado em História, Campinas: Unicamp, 2003.

BARBOSA, Silvana Mota. A Sphinge Monárquica: o poder moderador e a política imperial, Tese de Doutorado, Campinas: IFCH-Unicamp, 2001.

"A política progressista: Parlamento, sistema representativo e partidos nos anos 1860", in: José Murilo de Carvalho e Lúcia Maria Bastos Pereira das Neves, Repensando o Brasil do Oitocentos: cidadania, política e liberdade, Rio de Janeiro: Civilização Brasileira, 2009, pp. 295-324.

BARICKMAN, B. J. "Até a véspera: o trabalho escravo e a produção de açúcar no recôncavo baiano (1850-1888)". Afro-Ásia, vol. 21-22, 1998-1999, pp. 177-238.

BARMAN, Roderick J. Imperador cidadão. São Paulo: Editora Unesp, 2012.

BOEHRER, George C. Da monarquia à república: história do Partido Republicano do Brasil (1870-1889), Rio de Janeiro: Ministério da Educação e Cultura, 1950.

BONAVIDES, Paulo; AMARAL, Roberto. Textos políticos da história do Brasil (3 ${ }^{\mathrm{a}}$ ed.), Brasília: Senado Federal, 2002, v. 2. 
CALMON, Francisco Marques de Góes. Vida econômico-financeira da Bahia: elementos para a história de 1808-1899, Salvador: Fundação de Pesquisas, 1979.

CAMPANHOLE, Adriano; CAMPANHOLE, Hilton Lobo. Todas as constituições do Brasil, São Paulo: Atlas, 1971.

CARVALHO, José Murilo de. A construção da ordem e Teatro de sombras (4a ed.), Rio de Janeiro: Civilização Brasileira, 2003.

"As conferências radicais do Rio de Janeiro: novo espaço de debate", in: Id. (org.), Nação e cidadania no Império: novos horizontes, Rio de Janeiro: Civilização Brasileira, 2007, pp. 17-41.

Cidadania no Brasil: o longo caminho. Rio de Janeiro: Civilização Brasileira, 2001.

Liberalismo, radicalismo e republicanismo nos anos sessenta do século dezenove, Working Paper, Centre for Brazilian Studies, Oxford, 2007.

Os bestializados: o Rio de Janeiro e a República que não foi, São Paulo: Companhia das Letras, 1987.

CARVALHO, Maria Alice Rezende de. O quinto século: André Rebouças e a construção do Brasil, Rio de Janeiro: Revan, 1998.

CONRAD. Robert. Os últimos anos da escravatura no Brasil: 1850-1888 (2 ${ }^{\mathrm{a}} \mathrm{ed}$.), Rio de Janeiro: Civilização Brasileira, 1978.

COSTA, Emília Viotti da. Da Monarquia à República: momentos decisivos (3ª ed.), São Paulo: Brasiliense, 1985.

Da senzala à colônia, São Paulo: Difel, 1966.

COSTA, Milene Ribas da. A implosão da ordem: a crise final do Império e o Movimento Republicano Paulista. Dissertação de Mestrado em Ciência Política, São Paulo: FFLCH/USP, 2006.

COSTA, Wilma Peres. A Espada de Dâmocles: o exército, a Guerra do Paraguai e a crise do Império, São Paulo: Hucitec/ Campinas: Editora da Unicamp, 1996.

DANTAS, Monica Duarte Dantas. Fronteiras movediças: relações sociais na Bahia do século XIX (A comarca de Itapicuru e a formação do arraial de Canudos). São Paulo: Hucitec/ FAPESP, 2007.

"O código do processo criminal e a reforma de 1841: dois modelos de organização do Estado (e suas instâncias de negociação)". Conferência apresentada junto ao IV Congresso do Instituto Brasileiro de História do Direito, São Paulo, Faculdade de Direito/USP, 2009.

"Partidos, liberalismo e poder pessoal: a política no Império do Brasil. Um comentário ao artigo de Jeffrey Needell, Formação dos partidos políticos no Brasil da 
Regência à Conciliação, 1831-1857’'. Almanack Braziliense. São Paulo, nº 10, nov. 2009, pp. 40-47.

(org.). Revoltas, motins, revoluções: homens livres pobres e libertos no Brasil do século XIX, São Paulo: Alameda, 2011.

DIAS, Maria Odila Leite da Silva. Quotidiano e poder em São Paulo no século XIX (2a ed.). São Paulo: Brasiliense, 1995.

"Sociabilidades sem história: votantes pobres no Império, 1824-1881", in: Marcos Cezar de Freitas (org.), Historiografia brasileira em perspectiva. São Paulo: Contexto, 1998, pp. 57-72.

DOLHNIKOFF, Miriam. O pacto imperial: origens do federalismo no Brasil, São Paulo: Globo, 2005.

"Governo representativo e legislação eleitoral no Brasil do século XIX". Journal of Iberian and Latin American Research, v. 20, 2014, pp. 66-82.

"Representação na monarquia brasileira", Almanack Braziliense, São Paulo, no 9, mai/2009.

EISENBERG, Peter L. Modernização sem mudança: a indústria açucareira em Pernambuco, 1840-1910, Rio de Janeiro: Paz e Terra/ Campinas: Unicamp, 1977.

FERRAZ, Paula Ribeiro. O Gabinete da Conciliação: atores, ideias e discursos (18481857), Dissertação de Mestrado em História, Juiz de Fora: UFJF, 2013.

FERRAZ, Sérgio Eduardo. O Império revisitado. Instabilidade ministerial, Câmara dos Deputados e Poder Moderador (1840-1889). Tese de Doutorado em Ciência Política, São Paulo: FFLCH/USP, 2012.

FRANCO, Maria Sylvia de Carvalho. Homens livres na ordem escravocrata ( $3^{\mathrm{a}}$ ed.), São Paulo: Kairós, 1983.

FREITAS, Marcos Cezar de (org.). Historiografia brasileira em perspectiva, São Paulo: Contexto, 1998.

GRAHAM, Sandra Lauderdale. "O Motim do Vintém e a cultura política do Rio de Janeiro, 1880", in: Monica Duarte Dantas (org.), Revoltas, motins, revoluções: homens livres pobres e libertos no Brasil do século XIX, São Paulo: Alameda, 2011, pp. 485-510.

HOLANDA, Sérgio Buarque de. Do Império à República (2ª ed.), São Paulo: Difel, 1977 (Col. História Geral da Civilização Brasileira, t. II, v. 5).

Capítulos de história do Império (org. de Fernando Novais), São Paulo: Companhia das Letras, 2010.

HOLLOWAY, Thomas H.“The defiant life and forgotten death of Apulco de Castro: race, 
power and historical memory", E. I. A. L, Vol. $19-\mathrm{n}^{\circ} 1$ (2008).

JUCÁ, Joselice. André Rebouças: reforma \& utopia no contexto do segundo império, Rio de Janeiro: Odebrecht, 2001.

LIMA, Lana Lage da Gama. Rebeldia negra e abolicionismo. Rio de Janeiro: Achiamé, 1981.

LYNCH, Christian Edward Cyril. O Momento Monarquiano. O Poder Moderador e o pensamento político imperial. Tese de Doutorado em Ciência Política, Rio de Janeiro: IUPERJ, 2007.

MACHADO, Maria Helena Pereira Toledo. O plano e o pânico: movimentos sociais na década da abolição (2 $2^{\mathrm{a}}$ ed.), São Paulo: Edusp, 2010.

MAO, Guo-Ping. Homens e cousas in the age of reform, Brazil, 1868-1889, Tese de Doutorado em Filosofia apresentada à Universidade do Texas em Austin, 1997.

MARSON. Izabel Andrade. O império do progresso: a Revolução Praieira em Pernambuco (1842-1855), São Paulo: Brasiliense, 1987.

MATTOS, Hebe Maria. Das cores do silêncio: os significados da liberdade no sudeste escravista, Rio de Janeiro: Nova Fronteira, 1998.

MATTOS, Ilmar Rohloff de. O tempo Saquarema. São Paulo: Hucitec, 1987.

MELLO, Evaldo Cabral de (org.). Essencial Joaquim Nabuco, São Paulo: Penguin Classics Companhia das Letras, 2010.

O Norte agrário e o Império: 1871-1889 (2ª ed.), Rio de Janeiro: Topbooks, 1999.

MENDONÇA. Joseli Maria Nunes. Entre a mão e os anéis: a Lei dos Sexagenários e os caminhos da abolição no Brasil (2 ${ }^{\mathrm{a}}$ ed.), Campinas: Editora da Unicamp, 2008.

MESQUITA, Maria Luiza de Carvalho. O “Terceiro Reinado": Isabel de Bragança, a Imperatriz que não foi. Dissertação de Mestrado em História Social, Vassouras: USS, 2009.

MONNERAT, Tanize do Couto Costa. Abolicionismo em ação: o jornal Vinte e Cinco de Março em Campos dos Goytacazes (1884-1888). Dissertação de Mestrado em História Social, Rio de Janeiro: Unirio, 2013.

MONTANO, Leandro Duarte. Para além de um vintém: diálogos políticos e ação popular no Corte Imperial (1870-1880). Dissertação de Mestrado em História Comparada, Rio de Janeiro: UFRJ, 2009

MONTEIRO, Tobias. Pesquisas e depoimentos para a História, Belo Horizonte: Editora Itatiaia; São Paulo: Edusp, 1982.

MOTTA, Márcia Maria Menendes. Nas fronteiras do poder: conflitos de terras e direito 
agrário no Brasil de meados do século XIX. Rio de Janeiro: Arquivo Público/ Vício de Leitura, 1998.

NEEDELL, Jeffrey D. The party of order: the conservatives, the state and slavery in the Brazilian monarchy, 1831-1871, California: Stanford University Press, 2006.

"Formação dos partidos políticos no Brasil da Regência à Conciliação, 1831-1857", São Paulo, Almanack Braziliense ( ${ }^{\circ}$ 10), pp. 5-22, nov. 2009.

"Formação dos Partidos Brasileiros: questões de ideologia, rótulos partidários, lideranças e prática política, 1831-1888”, São Paulo, Almanack Braziliense ( $\left.\mathrm{n}^{\circ} 10\right)$, nov. 2009.

"Politics, Parliament, and the penalty of the lash: The significance of the end of flogging in 1886". Almanack. Guarulhos, n. 04, $2^{\circ}$ semestre de 2012, pp. 91-100.

QUEIROZ, Suely Robles Reis. "Escravidão negra em debate”, in Marcos Cezar de Freitas, Historiografia brasileira em perspectiva, São Paulo: Contexto, 1998, pp. 103-117.

REIS, João José; SILVA, Eduardo. Negociação e conflito: a resistência negra no Brasil escravista, São Paulo: Companhia das Letras, 1989.

RIBEIRO, Luaê Carregari Carneiro. Uma América em São Paulo: a Maçonaria e o Partido Republicano Paulista. Dissertação de Mestrado em História Social, São Paulo: FFLCH/USP, 2011.

SABA, Roberto N. P. F. “As 'eleições do cacete' e o problema da manipulação eleitoral no Brasil monárquico", Almanack. Guarulhos, n. 02, 2ºmestre de 2011, pp. 126-145.

A questão servil no debate parlamentar (1885): a Lei dos Sexagenários. Relatório de iniciação científica apresentado à FAPESP, 2007.

SALLES, Ricardo. "As águas do Niágara. 1871: crise da escravidão e o ocaso saquarema", in Keila Grinberg e Ricardo Salles (org.), O Brasil Imperial, vol. III: 1870-1889, Rio de Janeiro: Civilização Brasileira, 2009, pp. 39-82.

SCHULZ, John. A crise financeira da abolição, São Paulo: Edusp, 1997. $\overline{1994 .}$

O Exército na política: origens da intervenção militar, 1850, 1894, São Paulo: Edusp,

SILVA, Eduardo. Barões e escravidão, Rio de Janeiro: Nova Fronteira; Brasília: INL, 1984.

SILVA. Eleomar Candido Gonçalves. Cotidiano, política e protesto popular no Rio de Janeiro: 1880-1901. Dissertação de Mestrado em História Comparada, Rio de Janeiro: UFRJ, 2008.

SILVA, Lígia Osório. Terras devolutas e latifúndio: efeitos da lei de 1850 (2 $2^{\mathrm{a}}$ ed.). 
Campinas: Editora da Unicamp, 2008.

TAVARES, Luiz Henrique Dias (org.). Ideias políticas de Manuel Vitorino. Rio de Janeiro: Fundação Casa de Rui Barbosa, 1981, v. 1.

URBINATTI, Inoã Pierre Carvalho. Ideias e projetos de reforma agrária no final do Império (1871-1889): uma análise de seu sentido político e social, Dissertação de Mestrado em História, Rio de Janeiro: UERJ, 2008. 